

<smiles>[AsH][AsH]</smiles> 


\section{MARRIAGE CEREMONIES}

IN MOROCCO 


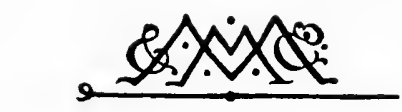
MACMILLAN AND CO. LIMITED
LONDON - BOMBAY - CALCUTTA MELBOURNE

THE MACMILLAN COMPANY

NEW YORK - BOSTON - CHICAGO

DALLAS - SAN FRANCISCO

THE MACMILLAN CO. OF CANADA, LTD.

TORONTO 


\section{MARRIAGE CEREMONIES}

IN

\section{MOROCCO}

BY

\section{EDWARD WESTERMARCK \\ PH.D., LL.D. (ABERDEEN)}

MARTIN WHITE PROFESSOR OF SOCIOLOGY IN THE UNIVERSITY OF LONDON

PROFESSOR OF MORAL PHILOSOPHY IN THE UNIVERSITY OF FINLAND, HELSINGFORS AUTHOR OF

'THE HISTORY OF HUMAN MARRIAGE,'

'THE ORIGIN AND DEVELOPMENT OF THE MORAL IDEAS,' ETC.

\section{MACMILLAN AND CO., LIMITED} ST. MARTIN'S STREET, LONDON

I 9 I 4 
COPYRIGHT 


\section{PREFATORY NOTE}

I HAVE to thank my friend Mr. Gerald C. Wheeler for kindly reading over both the manuscript and the proofs, and my friend and colleague Professor Knut L. Tallqvist for giving me his advice on some philological matter.

E. W.

Helsingfors,

8th Fanuary 1914. 
Digitized by the Internet Archive in 2007 with funding from Microsoft Corporation 


\section{CONTENTS}

\section{INTRODUCTORY}

The aim of the book, p. I.-The Muhammedan natives of Morocco, p. 2 sq. -The representatives chosen for them in the present investigation, p. 3 sq.-Differences in their language and customs, p. 4.The collection of the materials, pp. 4-6.-Earlier descriptions of marriages in Morocco, p. 6 sq.-The psychological origins of ceremonies, pp. 7-9.-Their historical origins, p. 9 sq.-The Moorish wedding ceremonies not empty formalities, p. $10 \mathrm{sq}$.-The system of transliteration, pp. 1 1-13.

\section{CHAPTER I}

\section{THE BETROTHAL AND MARRIAGE CONTRACT ('AQD EN-NIKĀH)}

Muhammedan law on the subject, pp. 15-18.-Marriages of young people in Morocco arranged by their parents, p. $18 \mathrm{sq}$.-Mediators, p. $19 \mathrm{sq}$. -Practices and ceremonies connected with the betrothal and marriage contract at Fez, pp. 20-29.-In Andjra, pp. 29-32.- Among the Ulâd Bu-Äzîz, pp. 32-34.-In the Hiáina, p. 34 sq.-Among the Ait Sádden, pp. 35-41.-Among the Ait Ndēr, pp. 41-44.-Among the Ait Waráin, p. 44 sq.-Among the At Ubáhti, pp. 45-48.-Among the At Zíhri, p. 48 sq.-Among the Ait Wäryâgäl, pp. 49-51.-Among the Ait Támeldu, p. $5^{1} s q .-W$ ritten contracts of marriage, p. $52 s q$. -Marriages between cousins, pp. 53-56.-Between members of the same village, p. 56.-Between persons belonging to different villages, ibid.-Between members of different tribes, ibid.-Between Berberand Arabic-speaking natives, p. $5^{6} \mathrm{sq}$.- Instances of strict endogamy, p. 57.-Prohibitions of intermarriage referring to some special tribes, subdivisions of tribes, or villages, in connection with other peculiarities in their social relations, pp. 57-59.-The institution of brotherhood, 
ibid.-Marriage with a deceased brother's widow, p. 59 sq.-A widow or divorced wife allowed to dispose of her own hand, ibid.-Subject to her father, ibid.-Customs relating to married women who have run away from their husbands, pp. 60-63.

\section{CHAPTER II}

\section{THE ŞDĀQ AND OTHER PAYMENTS-THE TROUSSEAU}

Muhammedan law concerning the dowry, p. 64 sq. - The dowry in Morocco, pp. 65-74.-Names for it, p. 65 sq. - The dowry fixed once for all by custom, pp. 66-69.-Among the Ulâd Bu-Ăzîz, p. 66 sq.At Amzmuz, p. 67.-Among the Iglíwa, p. 67 sq.-Among the Ait Támeldu, p. 68.-In Aglu, p. 68 sq.-Among the At Ubáhti, p. 69. -The dowry varying according to the circumstances, pp. 69-73.-At Fez, p. 69 sq.-In Andjra, p. 70.-In the Hiáina, p. 70 sq.-Among the Ait Sádden, p. 71.-Among the Ait Waráin, p. 71 sq.-Among the Ait Wäryâgäl, p. 72 sq.-Other payments and gifts to the girl's father, pp. 75-79.-The tá mamt, pp. 75-77.-The mákla, p. 77.-The hdiya, p. 77 sq.-Payments made to other members of the girl's family than her father, pp. 79-82.-Presents given to the girl by her betrothed, p. $82 s q .-$ By her father, p. $83 s q$.

\section{CHAPTER III}

\section{CEREMONIES IN THE BRIDEGROOM'S HOME PREVIOUS TO THE} FETCHING OF THE BRIDE

The giving of a wedding feast commended by Muhammedan law, p. 85.The wedding feast held in the bridegroom's home, ibid.-Names for wedding in Morocco, p. 85 sq. - The time for celebrating marriages, pp. 86-88.-Marriages avoided in certain periods, p. 86.-Celebrated on certain days of the week, p. 86 sq.-The cleaning and grinding of the wheat or corn which is to be used for the wedding, pp. 88-95.In the Garbîya, p. 88.--In Andjra, pp. 88-90.--Among the Tsul, p. 90 sq. - In the Hiáina, p. 91.-Among the Ait Sádden, p. 91 sq.Among the Ait Nderr, p. 92 sq.-Among the At Ubáhti, p. 93 sq.Among the Shlöh, p. 94.-Superstitious importance attached to the grit which has been removed from the wheat, p. 94 sq.-The painting of the bridegroom with henna and ceremonies connected with it, pp. 95-125.-In Andjra, pp. 95-99.-Among the Tsul, pp. 99-102.In the Hiáina, pp. 102-105.-Among the Ulâd Bu-Âzîz, p. 105.Among the Ait Waráin, pp. 105-110.-Among the Ait Nderer, p. 110. 
-Among the Ait Sádden, pp. Iro-ri2.-Among the At Ubáhtit, p. I12 sq.-Among the Ait Wäryâgäl, pp. I 13-116.-Among the Iglíwa, p. i 6 sq. - In Aglu, p. I 17.-Among the Ait Táměldu, ibid. -At Tangier, p. I I 7 sq.-Summary and explanations, pp. I 18 - I 25.Other ceremonies to which the bridegroom is subject before meeting his bride, pp. 125-133.-In Andjra, pp. 125-130.-Among the Ait Wäryâgäl, p. I $30 \mathrm{sq.-The} \mathrm{shaving} \mathrm{of} \mathrm{his} \mathrm{head} \mathrm{at} \mathrm{Fez,} \mathrm{pp.} \mathrm{I} 31-133 .-$ Other preparations for the wedding at Fez, pp. 133-1 35 .

\section{CHAPTER IV}

\section{CEREMONIES IN THE BRIDE'S HOME}

Ceremonies in the bride's home at Fez, pp. 136-140.-At Tangier, pp. 140-142.- In Andjra, pp. 142-146.-Among the Tsul, p. 146 sq.In the Hiáina, p. 147 sq.-Among the Ait Waráin, p. 148 sq.-Among the Ait Ndēr, p. 149.-Among the Ait Yúsi, pp. 149-1 52.-Among the Ait Sáddðn, pp. I 52-1 55.-Among the Aț Ubáhți, p. I 55.-Among the Ait Wäryâgäl, p. I 55 sq.-In Aglu, p. 156 sq.-Among the Ait Támeldu, p. 157.-Among the Igliwa, ibid.-At Amzmüz, ibid.Among the Ulẩd Bu-Ăzîz, pp. I 57-160.-Summary and explanations, pp. $160-164$.

\section{CHAPTER V}

\section{THE FETCHING OF THE BRIDE}

The fetching of the bride at Fez, pp. 165-167.-At Tangier, p. 167 sq.In the Garbîya, p. I68.- In Andjra, pp. I68-171.-Among the Tsūl, p. I7I sq.- In the Hiáina, p. I 72 sq.-Among the Ulâd Bu-Ǎzîz, p. 173 sq.-Among the Ait Sádden, pp. 174-178.-Among the Ait Yúsi, pp. 178-180.-Among the Ait Nd̄err, p. 180 sq.-Among the Ait Waráin, p. I8 1 sq.-Among the At Ubáhți, p. I82 sq.-Among the Ait Wäryâgäl, p. $183 .-$ In Aglu, p. 183 sq.-Among the Ait Támeldu, p. 184 sq. - Among the Iglíwa, p. i 85 .- At Amzmüz, p. I 85 sq.-Summary and explanations, pp. I86-192,

\section{CHAPTER VI}

\section{THE ARRIVAL AND RECEPTION OF THE BRIDE}

The arrival and reception of the bride at Fez, p. I93 sq.-In Andjra, p. 194 sq.-Among the 'Tsul, p. 195 sq.- In the Hiáina, p. 196 sq.In the Garbîya, p. r97.-Among the Ulầd Bu-Ăzîz, pp. 197-199.- 
Among the Aiț Sáddðn, pp. 199-203.-Among the Ait Yúsi, pp. 203-206.-Among the Ait Nd̦er, p. 206 sq.-Among the Ait Waráin, pp. 207-209.-Among the At Ubábți, p. 209 sq.-Among the Ait Wäryâgül, pp. 210-212.-In Aglu, p. 212 sq.-Among. the Ait Támeldu, p. 2 1 3.-Among the Igliwa, p. 213 sq. - At Amzmuz, p. 214.

-Suminary and explanations, pp. 214-224.

\section{CHAPTER VII}

THE MEETING OF THE BRIDE AND BRIDEGROOM AND THE MORNING AFTER

The meeting of the bride and bridegroom and the morning after at Fez, pp. 22 5-230.-In Andjra, pp. $230-235$.- Among the Tsal, p. 235 sq. In the Heáina, pp. 236-238.-Among the Ulâd Bu-Ǎzîz, p. $23^{8}$ sq. Among the Ait Sáddrn, p. 239 sq.-Among the Ait Yúsi, pp. $240-242$. -Among the Ait Nderr, p. 242 sq.-Among the Ait Waráin, pp. 243-248. - Among the At Ubáhti, p. 248 sq. - Among the Ait Wäryâgäl, p. 249 sq.-In Aglu, pp. $250-252 .-$ At Demnat, p. 252.Among the Ait Támeldu, p. 252 sq.-Among the Igliwa, p. 253 sq.At Amzmuz, p. 254.-Summary and explanations, pp. 254-271.The defloration of the bride said to be performed by somebody else than the bridegroom, pp. 271-273.-Remarkable intimacy between the bride and her imsnein or "vizier," p. 273.

\section{CHAPTER VIII}

\section{THE CONTINUATION AND END OF THE WEDDING}

The continuation and end of the wedding at Fez, pp. 274-279.- In Andjra, pp. 279-281.-Among the Tsal, p. 281.-In the Hiáina, p. 282.-Among the Ulâdd Bu-Ăzîz, pp. 282-284.-Among the Ait Nder, p. ${ }_{2} 8_{4}$ sq.-Among the At Ubáhti, p. 285 sq.-Among the Ait Warryâgäl, p. 286.-Among the Ait Waráin, p. 286 sq.--Among the Ait Sádden, p. 287 sq.- Among the Ait Yúsi, p. 288 sq.-Among the Igliwa, p. 289.-Among the Ait Támeldu, ibid.-Practices and taboos which spring from the idea that the bride and bridegroom are still exposed to supernatural dangers, pp. 289-291.-Ceremonies on the sixth or seventh day after the arrival of the bride, pp. 291-299.Visit paid by the bridegroom to his parents-in-law, p. 291.- The belting of the bride and ceremonies connected with it, pp. 292-295. Ceremonies following upon the belting of the bride, pp. 295-299.Ceremonies on the ninth day after nhar l:örs at Fez, p. 299. 


\section{CHAPTER IX}

\section{LATER CEREMONIES AND TABOOS}

Restrictions to which the young wife is subject, p. 300.-Visits which the young wife or her husband or both together pay to her parents, and other ceremonies, pp. 300-310.-At Fez, p. 301.-At Tangier, ibid. -In Andjra, p. 302.-Among the Tsul, ibid.-Among the Ulâd Bu:Ăzîz, ibid.- In the Hiáina, pp. 302-306.-A Among the Ait Sádden, p. 306 sq.-Among the Ait Yúsi, p. 307.-Among the Ait Nderr, p. $307 \mathrm{sq}$.-Among the Ait Waráin, p. 308.-Among the At Ubáhti, p. 308 sq.-Among the Ait Wäryâgäl, p. 309.-Among the Ait 'Táměldu, p. 309 sq.-A man's avoidance of his parents-in-law, pp. 310-317.-Of his brothers-in-law, pp. 310-312.- Shyness in the relations between a young man and his parents, pp. 313-316.-In the relations between the bride and her parents, p. 315.-Relations between a wife and her parents-in-law, p. $317 \mathrm{sq}$.

\section{CHAPTER $X$}

\section{SUMMARY AND EXPLANATIONS}

Various superstitious beliefs and practices connected with Moorish marriages, p. $319 \mathrm{sq}$.-Omens at weddings, p. $320 \mathrm{sq}$.-Customs springing from the feeling or idea that bride and bridegroom are in a state of danger, pp. $32 \mathrm{I}-325 .-F r o m$ the idea that the bride is a source of danger to others, pp. 325-328.-Why bride and bridegroom are supposed to be in a dangerous condition and the bride is considered to be dangerous to others, pp. 328-342.-Ceremonies practised in cases where either bride or bridegroom or both have been married before, pp. 328-334.At Fez, p. 329.-Among the Ulầd Bu-Ăzîz, pp. 329-331.-Among the Ait Sádden, p. 33 I sq.-Among the Ait Yúsi, p. 332.-Among the Ait Ndēr, p. 332 sq.-Among the Ait Wäryâgäl, p. 333.-Sexual intercourse looked upon as defiling and, under certain circumstances, as a mysterious cause of evil, pp. 334-338. - Notions held about the female sex, pp. 338-342.-The dangers to which bride and bridegroom are believed to be exposed, pp. 342-344.-The jnün in many cases personifications of the mysterious qualities of persons or lifeless objects, p. 343.-Ceremonies having a mixed origin, pp. 344-346. - The precautions taken at weddings readily assuming the shape of joyful performances, p. 344 sq.-Practices expressing or symbolising sexual bashfulness, p. 345.-Ceremonies expressing the antagonism which 
exists between different groups of people, p. 345 sq.-Ceremonies supposed to confer positive benefits on the bride or bridegroom or both, pp. 347-359.-E.g. to make their lives bright and happy or to bring good luck or prosperity, p. 347.-To increase the food supply, p. 347 sq.-To make the year good, ibid.-To facilitate the consummation of the marriage, p. 348.- To make the wife fruitful, and, particularly, a mother of male offspring, pp. 348-35 I (possibly 353).- To make the wife remain in her new home or to strengthen the marriage tie, pp. 353-355.-To make the husband fond of his wife, p. 355.-To make her the ruler, p. 355 sq.-To give the husband power over her or to make her a good wife, p. $35^{6} \mathrm{sq}$.- To make her dear to the bridegroom's family or to put her on good terms with her mother-in-law, p. 357.- In many cases impossible to make a definite distinction between protective or purificatory ceremonies and such as are held to result in more positive benefits, p. 357 sq.-Baraka as an element in the ceremonies connected with a Moorish marriage, pp. $358-362 .-$ Bride and bridegroom regarded as holy persons, pp. 359-362.-Marriage enjoined as a religious duty, p. 359.-Holy individuals or objects very susceptible to all kinds of harmful influences, especially those of a supernatural kind, p. 360.-The nature of baraka, ibid.-Benefits expected from a wedding, pp. 360-363.-A wedding looked upon as a potential cause of other weddings, p. $362 \mathrm{sq}$. - The presence of friends and guests held to benefit bride and bridegroom, p. 364.-The social importance of Moorish marriage ceremonies, p. $3^{6} 4 s q$.

ADDENDA (containing a discussion of the prohibition of marriage between kindred and exogamy).

- pp. $3^{67-376}$

INDEX OF ARABIC WORDS . . . . p $377-386$

INDEX OF BERBER WORDS . . . . . pp. 387-392

GENERAL INDEX • . • • • • • pp. 393-422 


\section{INTRODUCTORY}

THIs book is meant to be a kind of apology for a serious omission of which I was guilty when I wrote my History of Human Marriage, over twenty years ago. In that book I devoted only a very short chapter to the wedding ceremonies, and in my brief treatment of them I almost entirely failed to recognise their magical significance. This was afterwards strongly emphasised by $\mathrm{Mr}$. Ernest Crawley in his theory that the ceremonies of marriage are intended to neutralise the dangers supposed to be connected with all contact between man and woman and with the state of marriage itself, as also to make the union safe, prosperous, and happy - a theory which, as he himself acknowledged in the Preface to The Mystic Rose, was founded on Dr. Frazer's discovery of the primitive conception of danger attaching to the sexual act. For my own part I shall not here make an attempt to lay down any general theory as to the origin of marriage ceremonies, but shall restrict myself to the wedding customs of a single people, namely, the Muhammedan natives of Morocco, among whom I 
have spent some six years engaged in sociological research.

These natives are chiefly of Berber race, although the Berber language, which before the arrival of the Arabs undoubtedly was spread over the whole country, is nowadays mostly restricted to mountain districts. The Berber-speaking tribes, to whom alone the term "Berbers" is popularly applied, may be divided into several groups. There are the Berbers of the Rif, called Ruâfa, whose country extends along the Mediterranean coast from the neighbourhood of Tetuan to the Algerian frontier; the Brâber, who inhabit the mountain regions of Central Morocco and the eastern portion of the Great Atlas range; the Shlöh, who inhabit the western part of the Great Atlas and the province of Sus, situated to the south of it - a territory the eastern frontier of which may be roughly indicated by a line drawn from Demnat in a south-easterly direction, and the northern frontier by a slightly curved line uniting Demnat with Mogador on the Atlantic coast and following the foot of the mountains, or, in some places, intercepting a strip of the plain; and the Dráwa, who inhabit the valley of the Wad Drā in the extreme south of Morocco. As a fifth group must, from a linguistic point of view, be counted various tribes living in the neighbourhood of $\mathrm{Ujda}$, in the north-east of the country (At Buzéggu, Aț Zihri, At ‘ Ămár, Aț Shběl, Aț Lmệdi, Aț Yiznásěn, At Yảla, and Aț Ubáhți).

The Arabic-speaking people of Morocco consist of the "Arab ("Arabs"), who inhabit most of the plains; 
the Jbâla, who inhabit the mountains of Northern Morocco, north-west, west, and south-west of the Rif, towards the neighbourhood of $\mathrm{Fez}-\mathrm{a}$ group of tribes in whose veins, in spite of their language, there can hardly be a drop of Arab blood; and the Arabicspeaking inhabitants of the towns, who are often referred to as "Moors," although this name may be more conveniently applied to the Muhammedan population of Morocco in general.

I have, during my sixteen journeys to Morocco, been anxious to study the customs and beliefs of these various groups of people, and for this reason chosen representatives for all of them, with the exception of the Dráwa, as regards whom I have been unable to procure any reliable information. In this book the Ruâfa are represented by the Ait Wäryâgäl, better known under their Arabic name Beni Wäryâgäl; the Berbers in the neighbourhood of $U j d a$ by the At Ubáhti (Arab.

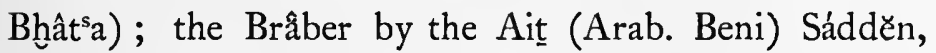
Ait Yúsi, Ait (Arab. Beni) Waráin, and Ait Ndēr (Arab. Beni Mțer); the Shlöh by the people of Aglu on the coast of Sas, the Ait Támeldu on the southern slopes of the Great Atlas range, the Igliwa inhabiting the district of Glawi in the same mountains, and the inhabitants of Amzmüz; the 'Arab by the Ulâd Bu-Ăzîz in Dukkâla, the natives of the Hianina in the neighbourhood of Fez, and those of the Garbîya in Northern Morocco; the Jbâla by the tribe of Andjra, on the southern shore of the Straits of Gibraltar, and the Tsul, one of the most southerly tribes of the 
group; and the townsfolk by the inhabitants of $\mathrm{Fez}$ and Tangier.

It must be understood, however, that the tribes belonging to the same group often differ more or less from each other in their customs, as they also do in their language. Whilst their dialects have a greater resemblance than those spoken within different groups, they may at the same time present considerable dissimilarities; the Shelha of Aglu, for example, is not the same as the Shelha of Glawi, and among the Brâber the language even of neighbouring tribes, like the Ait Sádden and Ait Waráin, may differ so much in its vocabulary and phonetics that a member of the one tribe sometimes finds it difficult to understand a member of the other and, as I have tested myself, is unable to imitate certain sounds of his dialect. As regards customs the local influence may be so strong that there is, not infrequently, a greater resemblance in this respect between "Arabs" and "Berbers" living in the same neighbourhood than between tribes belonging to the same group. On the other hand, it must not be supposed that the customs are quite uniform even within the same tribe.

I have myself visited many of the places and tribes mentioned in this book. Thus I have spent half a year in $\mathrm{Fez}$; the same length of time in Andjra, and several weeks in other tribes of the Jbâla ; some months in the Fahs ; about five months in the Garbîya ; nearly two months among the Ulâd Bu-Ǎzîz, besides which I had daily intercourse with men of this tribe during my five months' stay in Mazagan; three months among the 
Shlöh of the Great Atlas range ; and several months in Marrakesh and Mogador, where I employed Shlöḥ as my teachers. During my stay in Fez and Șefru and the excursions I made from the latter place to the surrounding tribe of the Ait Yúsi, I had a good opportunity to study the customs of Berbers belonging to the group of the Brâber, of whom it has been justly said that they are the least known people in Northern Africa. In Morocco very many districts are absolutely inaccessible to any traveller who cannot disguise himself as a native, and to do this is of course impossible in the case of a prolonged stay. Even for my sojourn in Andjra, which was then in a disturbed state, my Legation required of me a written statement to the effect that I went there entirely at my own risk. Yet the treatment I received there, as well as among other mountaineers and peasants not generally noted for friendliness towards Europeans, was invariably of the kindliest nature; and for this credit is due to my Moorish friend Shereef 'Abd-es-Salâm el-Baqqâli, who has accompanied me on all my journeys in Morocco and rendered me invaluable assistance. But also with regard to tribes which I have not visited myself I have in every case got my information from natives of those tribes, with the exception of the statements relating to the Ait Nder, most of which were made by an old Berber from another tribe who for very many years had been a resident among them-as also of a few other statements, the unauthoritative character of which is expressly mentioned in the text. 
My descriptions of wedding ceremonies are thus very largely drawn from oral information, which I have obtained both from men and women. This is true even in the case of tribes where I myself have been present at a wedding, either as an invited guest or as a spectator in Moorish disguise, since I obviously could not see everything which took place. I shall give the accounts of my informants in full in spite of the repetitions they contain; though these may be a little tiresome to the reader they will, at the same time; serve as a guarantee for the accuracy of the statements.

My subject is not altogether new, although a comparative study of the marriage ceremonies in the different parts of Morocco has not been attempted before. Previous writers have given longer or shorter descriptions of marriages celebrated in certain localities or tribes, such as Fez, ${ }^{1}$ Tangier, ${ }^{2}$ Alcazar (l-Qșar 1-Kbir), ${ }^{3}$ Demnat, ${ }^{4}$ and the Fahs,${ }^{5}$ Hlot ${ }^{6}$ Habț, ${ }^{7}$ and Rahámna. ${ }^{8}$ The present treatise, however, is entirely

I Leo Africanus, History and Description of Africa, ii. (London, 1896), pp. 448452. Eugène Aubin (Descos), Morocco of To-day (London, 1906), pp. 256-260.

2 Salmon, 'Les Mariages musulmans à Tanger,' in Archives marocaines, i. (r 904), pp. 273-289. Emily, Shareefa of Wazan, My Life Story (London, 1911), pp. $125^{-1} 3^{8}$.

3 Michaux-Bellaire and Salmon, 'El-Qçar el-Kebir,' in 'Archives marocaines, vol. ii. no. ii. (1904), pp. 66-72.

4 Saird Boulifa, Textes berberes en dialecte de l'Atlas marocain (Paris, 1908), pp. 5-23.

'Salmon, 'Une Tribu marocaine,' in Archives marocaines, i. (1904), pp. $207-212$.

6 Michaux-Bellaire and Salmon, 'Les Tribus arabes de la vallée du Lekkoûs,' in Archives marocaines, vi. (1906), Pp. 223-233.

7 Michaux-Bellaire, 'Quelques tribus de montagnes de la région du Habt,' in Archives marocaines, xvii. (1911), pp. $127-134$.

8 Doutté, Merrâkech (Paris, 1905), pp. 331-339.-In Budgett Meakin's book on The Moors (London, 190.2; pp. 361-375) a chapter is devoted to marriage, chiefly though not exclusively as it is celebrated at Tangier. Other references to marriage 
based on my own notes, though reference is occasionally made to facts recorded by my predecessors.

In my study of the wedding ceremonies I have not been content with ascertaining the bare external facts, but have, so far as possible, tried to discover the ideas underlying them. The reader will find that the explanations given by the natives themselves are not always alike. The reason for this may be either that the same ceremony has in different cases sprung from different sources, or that it has a mixed motive, or that its real origin has been forgotten and a new interpretation substituted for the idea from which it rose.

There is a tendency in Anthropology to assume that similar ceremonies have their roots in similar ideas, even when practised by different peoples; and this tendency has often led to ill-founded or even obviously erroneous conclusions. It should be remembered that, especially among simple peoples, the means of expressing ideas in actions are so limited, that the same kind of activity or the making use of similar objects may very often have a different psychological origin in different cases. Objects like corn, dried fruit, eggs, milk, etc., may be used for a variety of purposes; eggs in wedding ceremonies, for example, may be intended to promote fecundity on account of physiological associations, or to give good luck or make the weather fine on account

customs in Morocco are found in Mouliéras, Une Tribu Zénète anti-musulmane au Maroc (les Zkara) (Paris, 1905), pp. 82-96 ; Idem, Le Maroc Inconnu, i. Exploration du Rif (Oran, 1895), pp. 67, 68, 115 ; ii. Exploration des Djebala (Oran, 1899), pp. 494-499; and in some other books mentioned in M. Doutté's bibliography on the subject in his Merrâkech, p. 33 I sq. n. 2. 
of their white colour, or to facilitate sexual intercourse on account of the fragility of their shells. And if similar ceremonies may thus have sprung from different motives in different cases, it is obvious that also the same ceremony in a given case may be intended to serve more than one purpose; nay, there is no reason to deny the possibility of mixed motives from the beginning. At the same time it is well known that new interpretations are often given of old customs by the people who practise them, and that all ceremonies are apt to survive the ideas in which they have originated. This should not make the field-ethnologist less eager to find out the present meaning attached to the facts he records; whether or no it be the original meaning, it gives us in any case some insight into the ideas of existing people, and these are by themselves no less important subjects of inquiry than those of past generations. But I think that the aim of the field-ethnologist should not be only to observe and describe. Where the meaning of a custom is obscure or lost, his general knowledge of the native mind and its ways of thinking and feeling ought to enable him to make conjectures of much greater value than those suggested by "ethnologists of the study." I thoroughly disagree with the principle which I once heard expressed by the reader of a paper on some savage tribes at a meeting of the Royal Anthropological Institute, that the field-anthropologist should aim only at collecting facts and leave it to the anthropologists at home to explain them. But he must, of course, take the utmost care to avoid mixing up his 
own interpretations of facts with the observed facts themselves. This is a rule which I have strictly followed in the present treatise. In the detailed accounts of ceremonies or customs which form the substance of the book I have stated only such explanations as I have heard from my native informants (unless I have expressly said otherwise), reserving my own suggestions for the summary which I have given afterwards, mostly at the end of the chapter.

The difficulties in finding the ultimate psychological origins of ceremonies are frequently increased by the obscurity of their historical origins. A custom may spring up spontaneously among a certain people or tribe, or it may be imported from some other people or community; and to be complete, the study of it must be concerned not only with its intrinsic meaning but also with the question whether it has a native origin or not, and, in the latter case, from where it has been introduced. This study of its history is often an extremely difficult, not to say hopeless, task. It requires a profound knowledge not only of the customs of the people which is the subject of the investigation but of those of other peoples with which it has come in contact; and even with such a knowledge it may in many cases be impossible to decide with certainty whether we have to do with a loan or not. Considering how often absolutely identical customs are found among races living in very different parts of the world, under circumstances which exclude all possibility of a common origin, we have to take account of the fact that such 
customs may have grown up independently of one another also among peoples who have had much intercourse between themselves or even blended together. In Morocco the civilisation of the Arabic invaders has greatly influenced the Berbers, who have not only adopted their religion but also borrowed from them customs and superstitions falling outside the pale of Islam. Certain superstitious practices, which have been imported by slaves, have obviously a Sudanese origin. Indo-European influence may also have made itself felt ; or certain similarities in the customs of North African and European peoples may be due to racial affinity in accordance with the theory of the Mediterranean origin of the Berbers. But any attempt. to find the historical sources of the various customs and ideas prevalent in Morocco could never succeed in full, and must for the present be very incomplete, largely owing to our defective knowledge of the Arabs and of the Berbers of other countries. I shall, chiefly in footnotes, make reference to parallel cases among Muhammedans outside Morocco and European peoples, but these notes will be of a very fragmentary character; and the question as to the historical origin of the ceremonies described in this book must, in a large measure, be left for the consideration of future investigators.

The reader will perhaps deem many facts mentioned in this monograph too trivial to deserve the attention of serious students, but then he should remember that they do not appear trivial to the Moors themselves. Their wedding ceremonies are not empty formalities; 
but practices which are supposed materially to influence the welfare of individuals, families, and whole communities. And they reveal to us ideas and beliefs which, however foolish they may be, are potent forces in the social life of the people.

In rendering Arabic and Berber words and phrases used in Morocco I shall always endeavour to represent them as they are pronounced by the natives, independently of the written Arabic. As the same word is often pronounced differently in different places, the reader must not accuse me of inconsistency if he finds it spelt sometimes in one way and sometimes in another.

My system of transliterating the Arabic consonants is as follows:-

$B$ represents $\varphi ; d \nu$, or $j$ when pronounced as the English $d ; \underline{d} j$ when pronounced as th in this $; \dot{d} \boldsymbol{~}$, or $b$ when pronounced as $\nu^{\infty} d \dot{d}$ when not pronounced

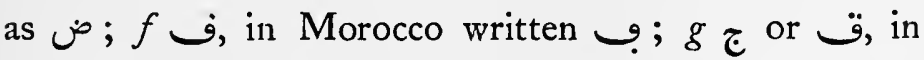
Morocco written $\boldsymbol{\Theta}$, when these letters are pronounced as $g$ in grand, a sound for which the Moors also use a ك with three dots above it; $\dot{\xi} \dot{\varepsilon} ; h^{\gamma} ; h^{\gamma}$; $h \dot{\tau}$; $j$ ? when pronounced as the French $j, d j$ representing the same letter when pronounced as the English $j$;

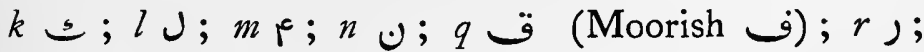

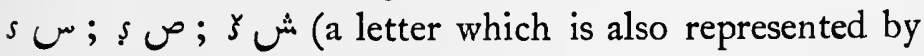
sh in names of common occurrence); $t \ddot{H}$, or $\uplus$ when pronounced as the English $t ; \underline{t} \uplus$ when pronounced as th in thing; $t b ; t^{s} \uplus$ or $\leftrightarrow$, when these letters are 
pronounced as $t s ; w$, when pronounced as $w$ in will; $y \_$when pronounced as $y$ in yoke; $z$; ' $\varepsilon$.

In some Berber words the following signs are also. used :-

$g^{y}$, to represent a sound which to me appeared almost as a. strongly pronounced consonantal $y$, but which my Berber scribe from the Ait Sádděn, who had a remarkably fine ear, considered to be more closely related to a $g ; \underline{h}$, corresponding to the German $c h$ in $i c h$; and $\dot{n}$, corresponding to $n g$ in sing.

The vowels are, at least approximately, to be pronounced as follows :-

$A$ as in Italian; $\dot{a}$ between $a$ and $0 ; a$ between $a$ and $\ddot{a} ; \ddot{a}$ as $a$ in fat; $e$ as in met; $e$ between $e$ and $i$; $i$ as in this ; 0 as in not; 0 as in German; $u$ as in put; $\hat{u}$ between $u$ and $o$; $\ddot{u}$ between $i$ and the French $u$.

The sign - over a vowel indicates that it is long; $\wedge$ that it is long and accentuated; - that it is very short; / that it is accentuated.

The vowel sounds of the words are subject to great variations, not only in different localities, but in the same locality, nay even in the mouth of the same individual - at least if he is asked to repeat the word. These sounds have probably caused me greater trouble than anything else in Morocco. The length of the vowel, in particular, is a very difficult matter, both because it is so changeable and because it allows of so very many different degrees; and equally difficult is it in many cases to distinguish between the presence or absence of a vowel sound before a consonant or between 
two consonants-to do so may even be absolutely impossible without the aid of phonetical instruments. I have made use of the signs,$- \wedge$, and $\smile$, only in cases when I have distinctly heard the sound pronounced either long or very short, but the omission of any such sign does not eo ipso imply that it might not have been used. Some distinguished students of colloquial Arabic have, perhaps under the influence of the written language, applied the symbol for length much more liberally than my ear has allowed me to do, whereas they have been more niggardly than myself in the matter of accentuation. It is true that the accent also, both in Arabic and Berber, is very changeable, and that the / or $\wedge$ over a vowel only indicates that $I$ have heard the syllable in which it occurs accentuated, not that it invariably is so; but that the accent is of hardly less importance than the length of the vowel appears from the fact that vowels which in the written language are marked as long have a distinct tendency to be pronounced short in syllables on which no stress is laid. 



\section{CHAPTER I}

THE BETROTHAL AND MARRIAGE CONTRACT ('AQD

$$
\text { EN-NIKĀH) }
$$

Munammedan law regards marriage (nikahh) as essentially a civil contract, the validity of which depends on proposal on one side and acceptance on the other.

When it is contracted on behalf of a woman who is no longer in her father's power, it is necessary that she should give her consent to it, either in express terms, or, if she be a virgin, at least by implication ; in the latter case her silence or laugh is construed to imply consent. $^{1}$ But according to the Maliki school of Muhammedans, to which the Moors belong, a woman cannot be married without the permission of her walt (guardian), ${ }^{2}$ who is in the first place her son by a former marriage, in the second her grandson (son's son), in the third her father, and, in default of these,

1 Ameer Ali, Mahommedan Law, ii. (Calcutta, 1908), pp. 334, 335, 343 sq.; Milliot, La Femme musulmane au Maghreb (Paris, 1910), p. 101 sq.; SIdI Halīl, Muhtasar, $\S 40$ (Russell and Abdullah al-Ma'mun Suhrawardy, ' $A$ Manual of the Law of Marriage' from the Mukhtașar of Stdt Khalil [London, s.a.], p. 12).

2 SIdt Halil, op. cit. $\$ 19$ (p. 5). A woman of low position, however, is allowed to marry without a walt (ibid. $\S 37$, p. 11 ). 
one or other of her paternal relatives in the following order: the full brother, nephew, grandfather, uncle, cousin. If she has no such relative, her wall is the qadj. ${ }^{1}$ The intervention of a guardian, says $\mathrm{Mr}$. Ameer Ali, is required "to supplement the presumed incapacity of the woman to understand the nature of the contract, to settle the terms and other matters of similar import, and to guard the girl from being victimised by an unscrupulous adventurer, or from marrying a person morally or socially unfitted for her." 2

If, on the other hand, the woman is still in her father's power, her consent is not required. Among the Hanafis the father's right to marry his daughter without her consent comes to an end when she arrives at puberty, ${ }^{3}$ but this is not the case among the Mãlikis. Among them she ceases to be in his power only by his death, or by her being expressly emancipated by him during his lifetime, ${ }^{4}$ or by her marriage (unless she has been married before puberty and the marriage has then been dissolved, or the marriage has been dissolved, without having been consummated, before she has lived a year in her husband's dwelling), or, according to some jurists, when she has reached the age of at least thirty. ${ }^{5}$

1 Sidi Halזl, op. cit. $\$ 32$ (p. 9).

2 Ameer Ali, op. cit. p. 335. Cf. Milliot, op. cit. p. 104.

3 Milliot, op. cit. p. 81 .

4 Emancipation, however, may be only for the purpose of enabling her to select a husband for herself, while her business affairs remain subject to the paternal control. Matrimonial guardianship is not necessarily coincident with guardianship of property and the superintendence thereof (Russell and Abdullah al-Ma'mun Suhrawardy, op. cit. p. 7 n. ${ }^{2}$ ).

5 SIdr Hुalil, op. cit. § 24 sq. (p. 6 sq.); Milliot, op. cit. pp. 79, 80, 87 sq. 
Among the Sunnis, to whom the Mãlikis belong, it is required that a proposal or declaration shall precede the acceptance, in order to demonstrate conclusively the intention of the parties. ${ }^{1}$ Their jurists recommend the use of the Fattihah, or opening chapter of the Koran, at the conclusion of the marriage, but do not, like the Shi'ahs, consider the use of it to be, to some extent, obligatory. ${ }^{2}$ In the contract of marriage are embodied the conditions to "which the husband binds himself, together with the amount of the dower, the nature of its payment, questions regarding the custody of the children, and other cognate matters. ${ }^{3}$ It is not necessary that this contract should be reduced to writing, a verbal contract of marriage and a verbal undertaking for dower being as valid in law as a written contract. ${ }^{4}$ But under the Sunni law it is required that there should be at least two witnesses present to attest the conclusion of the contract-to testify that it was properly entered into and in accordance with the conditions laid down for the contractual performance of marriage ${ }^{5}$ and the Mãlikis

I Ameer Ali, op. cit. p. 333 .

2 Ibid. p. 329. This recommendation is also generally followed. See GaudefroyDemombynes, Les Cérémonies du mariage chez les indigènes de l'Algérie (Paris, 1901), p. 15, and 'Abd El 'Aziz Zenagui, 'Récit en dialecte tlemcénien,' in Fournal Asiatique, ser. x. vol. iv. (1904), p. 74 (Tlemcen); Lane, Manners and Customs of the Modern Egyptians (London, 1896), p. 174, and Idem, Arabian Society in the Middle Ages (London, I883), p. 23 I (Egypt); Snouck Hurgronje, Mekka, ii. (Haag, 1889), p. 162 ; Burton, Personal Narrative of a Pilgrimage to Al-Madinah and Meccah, ii. (London, 1898), p. 23 (Medina); C. T. Wilson, Peasant Life in the Holy Land (London, 1906), p. 112 ; Guys, Un Dervich algérien en Syrie (Paris, 1854), p. 200 (Aleppo); Jaffur Shurreef, Qanoon-e-islam, or the Customs of the Mussulmans of India (Madras, 1863), p. 61 .

3 Ameer Ali, op. cit. p. 328.

4 Ibid. p. $5 \circ 3$.

5 Ibid. p. 325. 
insist that the witnesses should be " men of established reputation." I

In Morocco it is the universal rule that the parents of a girl marry her without asking for her consent. ${ }^{2}$ Not infrequently they also arrange the marriage of their son, even though he be grown-up, according to their own taste ; and "custom may require that he should comply with their wishes. ${ }^{3}$ Where the separation between the sexes is so strict as it is in many places in

I Sidi Halil, op. cit. $\$ 5$ (p. 2).

2 In Algeria, according to M. Villot (Maurs, coutumes et institutions des indigènes de l'Algérie [Alger, 1888], p. 76), "l'indépendance de la jeune fille est nulle dans la pratique." So also in Tunis (Sellami, 'La Femme musulmane,' in Revue Tunisienne, iii. [1896], p. 435), and many parts of Palestine (Klein, 'Mittheilungen über Leben, Sitten und Gebräuche der Fellachen in Palästina,' in Zeitschrift des Deutschen Palaestina-Vereins, vi. [1883], p. 88 sq.), the girl has no voice in the matter. But the Bedawin of the desert "differ entirely from all Mohammedan natives of Palestine in allowing their girls to accept or reject a proposal " (Robinson Lees, The Witness of the Wilderness [London, 1909], p. 120). Among the Aeneze the girl's wishes are consulted, and it is never supposed that she should be compelled to marry against her inclination (Burckhardt, Notes on the Bedouins and Wahábys [London, 1830], p. 61). In Mecca "die Jungfrau wird nur selten zur Heirath genöthigt; es geziemt sich aber durchaus, dass sie sich aufführt, als fügte sie sich den Plänen ihres Vaters nur aus Gehorsam" (Snouck Hurgronje, op. cit. ii. 1 57). Of the ancient Arabs Wellhausen ('Die Ehe bei den Arabern,' in Nachrichten von der Königlichen Gesellschaft der Wissenschaften zu Göttingen, 1893, no. 11, p. 431 sq.) writes :- "Der Valî, d.i. der Vater, Bruder oder Vetter der Braut, unter dessen Mund (Vilâ) sie steht, verlobt sie. . . Natürlich wird oft die Tochter, von liebenden Eltern, gefragt, ob sie den Freier haben will."

3 Among the Arabs of Moab, "en vertu du pouvoir presque absolu du père dans la famille, on s'accorde à lui reconnaître la faculté de disposer de l'avenir de ses enfants. C'est en effet le père du jeune homme qui traite directement avec le père de la jeune fille. . . . S'il s'agit du mariage d'un jeune garçon, très souvent les conditions sont arrêtées entre les parents à son insu, sans qu'il ait été consulté et parfois il ne connaît même pas sa future épouse. Mais dès qu'il atteint l'âge de dixsept ou dix-huit ans, il commence à faire valoir ses droits, et on est obligé de tenir compte de sa volonté. S'il déclare fermement qu'il ne veut pas de tel parti proposé, malgré toutes les combinaisons antérieures et les espérances des parents, le mariage n'aura point lieu" (Jaussen, Coutumes des Arabes au pays de Moab [Paris, 1908], p. 43). In Mekka "es kommt vor, dass der Jüngling sich zu den durch seinen Vater vorgenommenen Verhandlungen wegen seiner Ehe ziemlich passiv verhält, obgleich kein Zwang ausgeübt wird" (Snouck Hurgronje, op. cit. ii. 157). 
Morocco, this interference on the part of the parents can hardly be felt as a burden by the young man, especially as he can readily divorce a wife whom he does not like; and for the girl it would be no easy matter to choose between suitors whom she does not know. In tribes where the father actually sells his daughter his disposal of her is naturally influenced by the price offered, but elsewhere also her marriage affects his own interests as well as hers. In a country like Morocco family connections are of great importance, not only for a person's social position but even for his safety.

Whether the initiative in the matter is taken by the young man himself or his parents, the proposal is not made by him nor, generally, by his father, but by some influential man or friends, who have been asked to act as mediators. ${ }^{1} \quad$ These are called in Arabic hrațtâbin, sing. hatttab, and the proposal is called hotba. Women

I Among the ancient Arabs, also, the suitor often made use of a mediator (Wellhausen, loc, cit. p. 433 n. I). In Cairo, according to Burckhardt (Arabic Proverbs [London, 1830], p. 113), "when a girl is to be asked in matrimony, a friend or relation, or the sheikh of the young man (who has instructed him in reading the Koran), goes to the girl's father and makes a bargain for her." Among the Touareg the proposal is made by a holy man or some other important person (Bissuel, Les Touareg du Nord, p. 105, quoted by Gaudefroy-Demombynes, op. cit. p. I 1 n.). In ancient India “das Anhalten um die Braut beim Vater oder den sonstigen Verwandten geschah durch besondere Brautwerber, die aus den nächsten Anverwandten des Bräutigams genommen wurden" (Haas, 'Die Heirathsgebräuche der alten Inder,' in Weber's Indische Studien, v. (1862), p. 291. See also ibid. pp. $18 \mathrm{I}, 236,276,288,292,293,380,411$; Winternitz, 'Das altindische Hochzeitsrituell,' in Denkschriften der Kaiserl. Akademie der Wissenschaften, Philosophischhistorische Classe, x1. (Wien, 1892), pp. 2 1, 39 sq.). Similar customs have prevailed, or still prevail, in Europe (Weinhold, Die deutschen Frauen in dem Mittelalter, i. (Wien, 1882), p. 316 sqq.; v. Schroeder, Die Hochaeitsbräuche der Esten und einiger andrer finnisch-ugrischer Volkerschaften, in Vergleichung mit denen der indogermanischen Volker (Berlin, 1888), p. 32 sqq. Sartori, Sitte und Brauch, i. (Leipzig, 1910), p. 52 . 
friends are also, in many cases, busy with the preliminary arrangements; but the professional hattâba, or female match-maker, though not unknown in Morocco, plays there a less important rôle than in some other parts of the Muhammedan world, being chiefly employed by men without a family. ' The fancé is called in Arabic mméllek and the fiancée, mméllka.

After these general remarks I shall now pass to more detailed accounts of practices and ceremonies connected with the betrothal and marriage contract in various tribes and places in Morocco. These accounts refer to unions between young people whose parents are still alive. They illustrate one of the chief characteristics of the Moors-their fondness of having recourse to proxies and mediators whenever there is a possibility of refusal or dissent, and their shyness of straightforward questions and plain answers.

At Fez, as soon as a lad has arrived at the age when his parents think he should marry and the father can afford to pay the expenses for his wedding and the new household, they begin to make preparations for his

I Cf. Salmon, 'Les Mariages musulmans a Tanger,' in Archives marocaines, i. (1904), p. 275 ; Michaux-Bellaire and Salmon, 'El-Qçar el-Kebir,' ibid. ii. (1904), no. ii. p. 67. In An Account of South-West Barbary (London, 1713), written by a person who had been a slave in Morocco and edited by Ockley, it is said (p. 76) :-_"The Persons employed to negotiate this weighty Affair, are some antiquated, decrepid Matrons, whose Age secures them from all Suspicion of conversing with our Sex : Upon these they are obliged to repose all Confidence, and to act agreeably to their Measures and Directions, if they intend to bring the Business to any effect; yet they are often so deceitful, out of Favour to their own Sex, or for a small Bribe, as to give large Commendations where they are very ill deserved." For professional female match-makers among the Muhammedans of other countries, see, e.g., Lane, Arabian Society in the Middle Ages, p. 224 sq. (Egypt); Mrs. Meer Hassan Ali, Observations on the Mussulmauns of India, i. (London, 1832), p. 350 sq. 
marriage. After they have found a suitable girl his mother, with some other women of the family, calls on the girl's mother and speaks to her on the subject. She cannot, of course, give an answer before she has consulted her husband, and therefore asks the young man's mother to come back on a certain day. If either she or her husband is opposed to the match, she then makes the excuse that their daughter is going to marry her cousin, even though it be not so; for the Moors prefer telling an untruth to appearing uncivil. If on the other hand, both parents are in favour of the proposal, she informs the mother of the lad how much money her husband requires for their daughter, and this answer is communicated to the young man's father. Should the sum be much higher than the latter is willing to pay, his wife goes back and tries to get it reduced. If she definitively fails in this, the matter drops ; whereas, if there is a fair prospect of success, her husband asks two or more respectable men with baraka (holiness) in them-shereefs or scribes-to go with him and negotiate with the girl's father. They call on him, not in his house but in his business place, or workshop, addressing him with the words, S-salâmu "álikum, daif ălláh, "Peace be on you, guest of God"; and ask him to come with them to the mosque. There they broach the question of the price he demands for his daughter, and he mentions a sum, say, three hundred

I In Palestine, says the Rev. C. T. Wilson (op. cit. p. 108 sq.), "even if the proposal be unacceptable, it is, I believe, rarely if ever met by a direct refusal ; but in the subsequent negotiations some condition impossible of fulfilment, such as an exorbitant dowry, is required, which puts an end to the matter." 
dollars. According to instructions previously given by the lad's father, who himself takes no direct part in the negotiations, his friends make objections and propose a smaller sum, for instance, two hundred dollars, which the girl's father in his turn finds too little; and the result will probably be that the price is fixed at about two hundred and fifty. When this has been settled they all make fâts $h a,{ }^{1}$ and the girl's father then goes home to inform his wife of the agreement. The women of the house make a quivering noise, ${ }^{2}$ but the girl bashfully hides herself, not seeing her father for several days. Similarly the young man's father tells his wife what has passed, and in his house also the women make the same kind of noise. But the lad himself keeps away from his father. There has never been any conversation at all between them on the matter; and only in a quiet and guarded way does his mother let him understand who will be his wife, without his having ever expressed the slightest wish to

1 The ceremony of fâts ha consists in the recitation of a prayer with the hands stretched out and the palms turned upwards. Dr. Vassel (Úber marokkanische Processpraxis [Sonderabdruck aus den Mittheilungen des Seminars für Orientalische Sprachen zu Berlin, Jahrg. v. Abth. ii., 1902], p. 19) says that it should not be confounded with the fatika, or opening chapter, of the Koran. Yet there can be little doubt that it has its name from that chapter, even though it does not in Morocco necessarily include a recitation of it. See Marçais, Textes arabes de Tanger (Paris, 1911 ), p. 165 n. 3 ; Snouck Hurgronje, op. cit. ii. 35, especially n. 2.

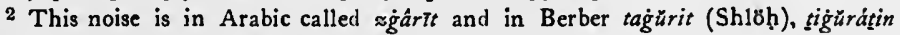
(Aiț Yúsi), asğürț (Aiţ Sádden), tililau (Ait Waráin), țimušiț (Aț Ubáhți), or sriwriwện (Ait Wäryâgäl). Dr. Jansen ('Mitteilungen über die Juden in Marroko,' in Globus, 1xxi. [ 1897 ], p. $360 \mathrm{n.}{ }^{7}$ ) says that it "durch äusserst schnelle, horizontale oder seitliche Bewegung der Zungenspitze zwischen den Lippenwinkeln hervorgebracht wird, wobei ein schriller Trillerlaut entsteht, der fast wie ein hundertmal äusserst schnell wiederholtes 'lü' klingt... (etwa in der Tonhöhe des zweigestrichenen $f$ oder fis), ungefähr $\frac{1}{2}$ bis $\frac{3}{4}$ Minute (solange der Atem vorhält) dauert und plötzlich mit einem sehr kurzen, sich wie '. . . it' anhörenden Abschnapp-Laute zum dreigestrichenen $c$ oder cis hinaufschnellend schliesst." 
marry. He has never seen the girl chosen for him, unless she be his cousin.

A few days after the proposal has been accepted some eight or ten women of the young man's family or kin, including his mother, go to visit the girl's mother, who entertains them with tea, food, and honey, the object of the honey being to make the daughter "sweet" to the family of her future husband so that there shall be no quarrel between them. ${ }^{1}$ This feast, in which also other women besides her mother partake, is called kémlet l-a tîya, because "the giving away" of her has now come to an end. The girl is not present on this occasion, but hides herself so as not to be seen.

On the following Friday the fathers of the young man and girl, together with a number of friends, meet at the time for the midday or afternoon prayer at some shrine, by preference that of Mûläi Idris, or in the zawia of the fraternity to which the young man's father belongs. After prayer the following ceremony, called $f \hat{a} t^{s} h a$, is performed. When the young man's father and his party are assembled together in one place and the girl's father and his party in another place close by, a man of the former party-by preference the family barber, and in no case the young man's father-

1 Although honey is thus used before a wedding as a charm for good luck, it is never served at the wedding itself, the partaking of it being a regular feature of a funeral. (In ancient Greece honey played a prominent part in the cult of the dead; see Samter, Familienfeste der Griechen und Römer [Berlin, 1901], p. 84.) The bridegroom, however, not infrequently makes use of honey as an aphrodisiac. $C f$. Doutté, Merrâkech (Paris, 1905), p. 335 :-“Le miel, sauf certains cas spéciaux, est souvent chez les Musulmans et spécialement chez les Marocains, considéré comme étant de mauvais augure et même si, durant la noce, on en fait circuler, on évite qu'il passe sous les yeux de la jeune mariée." 
goes and stands between the groups, who now form a ring round him. He says, Fâtsha, and stretches out his hands in the usual manner with the palms turned upwards; and all the men round him follow his example. With his hands still in this position he looks round and lets his eyes rest on some shereef or other man with baraka in him and asks him to finish the ceremony, saying to him, Hitsem ya siddi. The man thus addressed moves his hands over his face and chest, kissing them lightly as they pass his mouth, and the same gesture is repeated by everybody present, the person in the centre

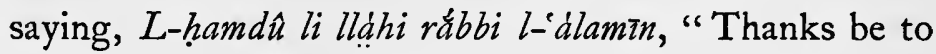
God, Lord of the worlds." Then the hands are again stretched out and the former ceremony is repeated. The men belonging to the party of the young man's father go to the latter and give him their right hand, saying, Mbârăk mes'ồd, "Be blessed and lucky," to which he answers, Allàh ibârěk fik, "May God bless you." The men of the other party do the same to the girl's father. Then the two fathers receive a similar homage from the men of the opposite party, after which they all go away.

In the afternoon of that day the young man sends some new clothing to his future wife, and she at sunset sends to him small tables (miâdi) with sugar, fresh butter, milk, mint ( $n \hat{a}^{e} n a^{\prime}$ ), ka'b gzel (crescents made of an icing of pounded almonds, sugar, and cinnamon, covered with an extremely thin coat of pastry), and griba (buns made of flour, sugar, and butter). When these tables are returned the young man must put on 
one of them a fine garment as a present to his betrothed. In the evening a feast is given in his father's house, with musicians and invited guests. After supper so-called ngâgef-free negresses whose business is to assist women on festive occasions-dress up the young man as a bride with garments which they have brought with them. He is then seated on cushions placed on a mattress opposite the door, and sits there with his eyes closed as if he were a bride. One of the ngâgef sings:-Fäinkum ya șhab lă-rûs? "Where are you, O friends of the bridegroom ?" The young man's friends now enter the room. A nggâfa gives him some milk to drink, and another, with a plate of dates in her hand, puts into his mouth a date. After this they give milk and a date to each of his friends, who in their turn put money on his forehead, fixing it there with spittle, while the women in the upper floor of the house, as well as the ngâgef, make a quivering noise. The money is immediately removed from the young man's forehead by one of the latter. ${ }^{1}$ The milk offered on this occasion is supposed to make his life " white," while the dates represent wealth, in accordance with the common blessing, Alláh it'ámmar $u$ idammar, "May God give dates and plenty" (literally "fill"). This occasion is called lîlets fâtsha, "the evening of fâtsha."

No native explanation of the custom of dressing up

1 " The custom of sticking coins to the forehead of a bridegroom is common to several races of the East, amongst others to the Turcomans, who inhabit the villages round Mosul" (Layard, Discoveries in the Ruins of Nineveh and Babylon [London, 1853], p. 206). 
the young man as a bride has been given to me. Disguises at marriages have been found in various other countries, ${ }^{1}$ and many writers have suggested that their object is to deceive malignant spirits who lie in wait for the young couple at this season. ${ }^{2}$ According to Mr. Crawley's theory of "inoculation," on the other hand, the bride or bridegroom assumes the dress of the opposite sex in order to lessen the sexual danger by wearing the same kind.of clothes as "the loved and dreaded person." 3 The former explanation can hardly apply to the Fez custom of dressing up the young man as a bride, since the bride is supposed to be haunted by evil spirits as much as, or even more than,

1 See v. Schroeder, op. cit. p. 68 sqq.; Crawley, The Mystic Rose (London, 1902), p. 37 s sq.; Farnell, 'Sociological Hypotheses concerning the Position of Women in Ancient Religion,' in Archiv für Religionswissenschaft, vii. (1904), pp. 75, 89 sg.; Frazer, Totemism and Exogamy, iv. (London, 1910), p. 255 sq.; Fehrle, Die kultische Keuschheit im Altertum (Giessen, 1910), p. 92 ; Samter, Geburt, Hochaeit und Tod (Leipzig \& Berlin, I9r1), p. 91 sqq. In ancient Cos, according to Plutarch (2uaestiones Graecae, 58), the bridegroom was dressed in women's clothes when he received his bride; whilst in Sparta, after the bride had been carried off by her husband, "the bridesmaid received her, cut her hair close to her head, dressed her in a man's cloak and shoes, and placed her upon a couch in a dark chamber," where she had to wait for the entrance of the bridegroom (idem, Lycurgus, xv. 4). Among the Egyptian Jews in the Middle Ages the bridegroom "donned feminine attire, and the youths wore girls' clothes and put the favourite henna dye on their finger-nails," whilst "the bride wore a helmet and, sword in hand, led the procession and the dance" (Abrahams, Fervish Life in the Middle Ages [London, 1896], p. 193). Among the people of Southern Celebes the bridegroom at one stage of the proceedings puts on the garments which have just been put off by the bride (Matthes, Bijdragen tot de Ethnologie van Zuid-Celebes ['s Gravenhage, 1875], p. 35). Among the Masai in Eastern Africa, according to Thomson (Through Masai Land [London, 1887], p. 258), the bridegroom had to wear the garment of a girl for one month.

2 Gruppe, Griechische Mythologie und Religionsgeschichte (München, 1906), p. 903 ; Nilsson, Griechische Feste von religioser Bedeutung mit Ausschluss der attischen (Leipzig, 1906), p. 372 ; Schwally, Der heilige Krieg im alten Israel (Leipzig, 1901), p. 76 ; Reinach, Cultes, mythes et religions, i. (Paris, 1905), p. 116 ; Samter, Gehurt, Hochzeit und Tod, p. 93 sqq.; Frazer, op. cit. iv. 257.

3 Crawley, op. cit. p. 371 sq. 
the bridegroom himself; but it better agrees with Mr. Crawley's theory, according to which the greatest possible assimilation between the bride and bridegroom would best serve the purpose of neutralising the sexual danger. We shall see that in some country places in Morocco the bride on her part imitates the appearance of a man by wearing her shawl thrown over her left shoulder, or leaving her old home clad in a man's cloak, or having designs resembling whiskers painted on her face. These customs may with more reason be supposed to have been intended as means of protection against dangerous spirits or, especially, against the evil eye. And this is in a still higher degree the case with the assumption or imitation of the costume of the bride or bridegroom by other persons than the principals at the ceremony, ${ }^{1}$ a practice which, as will be seen, is also met with in Moorish wedding ceremonies.

In the afternoon of the day of fâts ha the girl goes to the hot bath, and in the evening her parents give a feast in their house, to which have been invited female relatives. Besides these women guests, called httatar (sing. hatțâra), there are also present ngâgef and tabbâlats (female musicians). The girl is dressed up in a fine costume, which the ngâgef brought with them, and is then seated on cushions on a mattress opposite the door. Exactly as in the case of her betrothed, and with a similar purpose in view, a $n g g \hat{a} f a$ gives her some milk to drink, and another, with a plate

1 Cf. Crooke, Popular Religion and Folk-Lore of Northern India, ii. (Westminster, 1896), p. 8 ; Sartori, op. cit. i. 75 ; Frazer, op. cit. iv. 256 sq. 
of dates in her hand, puts into her mouth a date. After this they give milk and a date to each one of the htattar, and the latter decorate the girl's forehead with silver coins, which are taken by the ngâgef.

It should be added that if the parents of a girl refuse to give her away in marriage to a man who is very anxious to have her and makes repeated attempts to induce them to yield to his wishes, she is supposed to remain unmarried on account of a curse pronounced by the unsuccessful suitor until the spell is removed from her in the following manner. Her chemise is given to the mudden on a Friday to be taken up to the minaret (sómia) at ten o'clock, when the blue flag is to be changed for the white. He hoists the chemise instead of the latter, lets it remain hoisted till the beginning of the midday prayer, and then returns it to the girl, who puts it on the same day. If this does not prove effective, some member of her family brings a little earth from seven different places, namely, the entrance of a mill, a public oven, a public hot bath, a mosque, the room where the judge pronounces his sentences (le-mhåkma del-qâdi), a public inn (féndaq), and some place where two streets cross-these places being chosen because they are trodden on by many men. Then water is brought from the sanctuaries of seven saints. Some of it is drunk by the girl, with another portion she washes her face, and what remains is mixed with the earth, which, when dried, is enveloped in a small piece of rag and hung on her dress. It is 
believed that the holy water will make her look very attractive, and that she will soon marry.

In Andjra a young man who wants to marry a certain girl mentions it to his uncle or aunt, in order that it shall be made known to his parents. If the latter are opposed to the match, and refuse to make arrangements for it, the son may nevertheless carry out his wishes by threatening to commit some disreputable act which would cause them trouble. But it may also be that the parents take the first step and let the son know of their plans through somebody else. If he is unwilling, the matter drops, whereas, if he agrees, he bashfully expresses his consent by the phrase, Hûma iárfu, "They know best." Then his mother calls on the girl's mother to tell her of the contemplated proposal. If the latter is against it, she answers that her daughter is already engaged, whether she be so or not; whereas a Marhabâ bikum, "Be welcome," is a sure sign that she is in favour of the match. The two mothers agree as to the day when the proposal is to be made, and there can now be little doubt that it will be accepted, since the marriage of a girl is in most cases practically arranged by her mother. On the appointed day the young man's father, in the company of the $f q \bar{\imath}$ (schoolmaster) of the village and two other respectable men, pays a visit to the girl's father, taking with him some candles and sugar, or salt butter and honey. They greet him with the phrase, Daif nă lldh, " [I 
am] the guest of God "; to which he answers, Marhabâ bikum, "Be welcome." After he has entertained them with tea and food, the $f q \tau$ asks him if he is aware of the nature of their errand. "You are welcome," he says, "whatever your errand be." The $f q \bar{l}$ explains the object of their visit, to which the girl's father replies, $U$ s-salậm, dna a țtitâa lu ila a'tahâ lu llah, "Well and good, I have given ${ }^{1}$ her to him if God has given her to him." The $f q \tau$ asks the father what his conditions are. The latter says, "The custom which the people follow also we shall follow." He goes and consults his wife, and then answers the $f q i^{\prime} s$ questions in accordance with her advice. When the $f q z$ asks the amount of the sdaq, the father answers, for example, forty dollars. The $f q \bar{\tau}$ maintains that it is too much, and offers, say, thirty; and whatever he proposes will be accepted. When they have agreed as to the sdaq the $f q$ i asks, "What else do you want ?"-The father answers, "I want the $h \underline{d} \hat{i} y a$ (present)."-The $f q \bar{\imath}$ : "What will that be ?"-The father : "A big bullock." -The $f q \bar{\imath}$ : "Oh not a very big one."-The father : "A big jar ( $\left.q d \mathfrak{d}^{\prime} a\right)$ of salt butter."-The $f q \bar{\imath}$ : "A small one will suffice." - The father: "A jar ( $\left.\tan ^{d} j \hat{i} y a\right)$ of oil."-The $f q \bar{\tau}$ : "Oh no, half a jar."-The father : "Thirty mudd of corn."-The $f q \bar{\imath}$ : "Only fifteen."The father: "Ten pairs of slippers" (intended both for the girl and other members of the family).-The $f q \bar{t}$ : "Only five."-It is also agreed that the girl shall have

1 Cf. Hidäyah, English translation, i. 72 (quoted by Ameer Ali, op. cit. ii. 329) :"Marriage is contracted by means of declaration and consent, both expressed in the preterite." 
a hâyẹ̆k or two for wear, a carpet (zarbîya), a wooden trunk (sóndì q), a mirror ( $m r \bar{a})$, a mattress (mḋ̀rrba), and bed-clothes, which are all regarded as part of the sdaq to be mentioned in the written contract. When an agreement has been arrived at, fâts ha is made, the fqi taking the lead. This day is called nhar l-kmäl, " the day of finishing."

A day or two afterwards the men of the young man's village go to his house, fire off three volleys of gunpowder in the yard, and wish his parents good luck with the common phrase, Alláh ikémmel b̆ l-ḩäir! They are served with tea and kúsksu; but before the meal the bachelors, in order to get good entertainment, say to the young man's mother :- "O so-and-so, aunt so-and-so, we shall now see how your son's wedding will be. We are happy that he is going to marry. May God let us live and enjoy quietness (Ălläh yähyîna u ihännîna) till then, if God will." This day is called nhar l-mämla, and the feast given in the fiance's house is called l-mlak. If no feast is given, the bachelors of the village catch hold of the young man, put him into a kind of hammock, which they suspend between two trees, and leave him there till he entertains them with a meal.

At every religious feast the young man sends his betrothed a silk kerchief (sěbnîya) and some henna, and at the Great Feast a sheep and some salt butter as well, receiving a garment in return. ${ }^{1}$

1 Among the Muhammedans of India the betrothed persons exchange presents on the day of the Great Feast, and indeed at any religious feast which may occur before their wedding (Mrs. Meer Hassan Ali, op. cit. i. 366 ). 
If a young man cannot get the girl whom he wants to marry, the other young men of the village tease him by firing off their guns opposite his house and

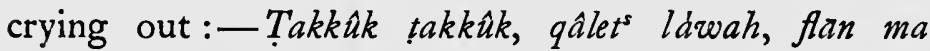
narddwah, had ahobr ardwah, "Cuckoo, cuckoo, she said No, we do not approve of so-and-so, bring somebody else." Out of shame the disappointed lover leaves the village for some time or confines himself to his house for several days. A similar custom prevails in the mountain tribe Jbel lä̆-Hbib, where I heard the cries of the young men on two successive evenings.

Among the Ulåd Bu-'Ăzîz a young man who wants to marry generally asks his mother for her advice. If more than one girl is thought of and it seems difficult to decide who is the most suitable, the mother takes as many wooden pins as there are girls, each of whom is represented by a pin, and asks some man or lad to draw one so as to find out the best bride for her son. The proposal is made through a shereef or the $Y e h$, or chief of the village, who, accompanied by a few other influential villagers, pays a visit to the girl's father. His greeting, Daif allah, " $[\mathrm{I}$ am $]$ the guest of God," is answered by the latter with the following words :-Márhăba bi daif alláh; bérku hadtta tâklu, ifárrăj ălláh, "Be welcome guest of God; sit down till you have eaten, God will disperse all troubles." The spokesman of the visiting party says that they will sit down if there is reason for doing 
so, but that they otherwise are going away. If the girl's father, who of course knows their errand, is unwilling to give his daughter in marriage to the young man, he either tells them so in plain words or, if he wants to be civil, says that he will give her if his conditions are accepted. In this case the men go away as soon as they have partaken of the food offered them; whereas if he consents, declaring that though his daughter is dear to him they are dearer still, the agreement is confirmed by a fâtha after the meal of séksu which they eat together.

When the betrothal has been made, the parents of the young man, in company with the married women of the village, as well as male friends, take to the girl's family a present consisting of a sheep or bullock, wheat, and salt butter. When taking it there the women make their usual quivering noise, called $z \dot{g} \hat{g}$ ar $\mathbf{t}$, which is also the name given to the present. After their arrival they grind the wheat, and while this is going on they again make their quivering noise, in which the other women who are present join. Underneath the mill is put a silver coin, which has been sent by the young man to make things "white" or lucky, and which is afterwards taken by the girl or her mother. When the grinding is finished, the young man's father gives to the girl's mother a small sum of money - a dollar or even less - to be distributed among all the women present, as also the other women

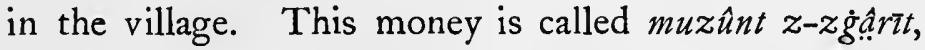
a muzûna being an imaginary Moorish coin not even 
worth a farthing. Before leaving, the visiting party are entertained with a meal. The young man himself did not go with them. If his betrothed is living in another village he has probably never seen her, but only chosen her on his mother's or sister's recommendation.

The next market-day the young man buys some meat, dates, henna, and cotton- and silk-stuff to present to his betrothed. He now goes himself to her village, accompanied by his bachelor friends, but does not enter her tent. In return for this present, which is called t-tạbiêda, the girl sends the young men a dish of rệs $s$-chickens boiled with onions, black pepper, salt, and butter, and served with pieces of thin cakes called rgaif_or, if she is of a poor family, only séksu with meat laid on the top. When the young man and his friends have finished their meal, they leave in the empty dish ( $g$ ds śa) some money, which is taken by the girl's mother to be spent on her daughter's trousseau. This visit, with its presents and entertainment, is repeated at every religious feast till the wedding is celebratedit may be for a year or two, or, if the girl is very young, even longer. Good parents, I was told, marry their daughters while still in their childhood; and fathers not infrequently marry their sons when they are fifteen or sixteen years of age. Early marriages are looked upon with favour as preventing sexual irregularities.

Among the Arabs of the Hiáina, if a father wants 
to marry his son to a certain girl, the youth makes no objection, but submits; he is not, however, informed of the matter by his father, but hears about it from others. When the father goes to make the proposal, he takes with him a shereef to act as mediator, and should the girl's father show himself unwilling to give his daughter in marriage, the other male relatives of the girl are by presents, the so-called réswa ("bribe"), induced to prevail upon him to change his mind. Sometimes a sacrifice is resorted to as a means of persuasion. In the Hiáina, also, the betrothal is followed by a fâts $h a$, and subsequently a feast called

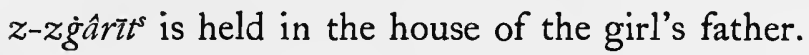

From Arabic-speaking natives we shall pass to Berber-speaking tribes, beginning with some belonging to the group of the Brâber.

Among the Ait Sádděn a father not infrequently arranges his son's marriage before the latter has reached the age of puberty, particularly in the case of an only son. The girl, who may be considerably older than her betrothed, is then taken to the father's home, though the wedding is only celebrated when the boy becomes of age; and should she get with child before that occasion, it is assumed that the young man, and nobody else, is the father. Much more often, however, the marriage contract is made when the son is grownup. He may then himself take the first step by asking somebody to inform his father of his desire to marry a certain girl. Among the Ait Sádden all the 
young men and women of a village are well acquainted with each other. In moonlight nights they are in the habit of dancing the aheidus together, and on Fridays, when the women and girls go to fetch fuel from the thicket, the young men frequently join them. The latter also know girls from other villages, whom they have met at markets or weddings, or whose acquaintance they made when they, as schoolboys in their holidays, went about from village to village with one or two donkeys, begging corn, butter, eggs, and money to give to their schoolmaster. The young man may also speak to his mother about his love, but would never mention it directly to his father. If either the latter or the girl's father objects to the match, the young couple may carry through their will by eloping to another village or tribe, not to come back until their marriage is agreed to. The wedding is then celebrated on their return, or at all events the villagers are entertained with a dish of $t t a c a m$ (sćksu) in the mosque as a formal announcement of the marriage. But if the son is strong and the father powerless, no notice is taken of the latter's opposition, and a mother's wish is not regarded at all. These Berbers have little respect for their parents, differing in this point from many Arabic-speaking tribes; it is by no means uncommon among them that a son beats his mother and fights with his father.

The proper custom, however, is that the father chooses a wife even for his grown-up son. He does so without saying a word about it to the young man, 
who only learns from his mother what is going on; and if he has not already himself made his choice, he quietly puts up with his father's decision. The latter sends his wife and some other women to the house or tent of the girl's family to let her mother know his designs. These women are called timsuttrin, corresponding to the Arabic hattâbat. The girl's mother must, of course, speak to her husband about the matter, whereas the daughter's own wishes are not considered at all. Yet it lies in her power to influence the proceedings. If she is fond of the young man, she dresses herself in fine clothes and sits down with the timsütrin, trying to be as attractive as possible; on the other hand, if she dislikes him, she makes use of bad and ominous words which should not be mentioned on this occasion, ${ }^{1}$ or she behaves like a woman at a funeral, scratching her face and dirtying herself with cowdung. The result of this may be that no further steps are taken, for fear lest a marriage arranged under such circumstances should be unlucky. Moreover, it has sometimes happened that the girl has prevented the proposed marriage by running away on this occasion, or even on the very day of the intended wedding.

If the girl's mother is in favour of the match, she endeavours to influence her husband by singing the

1 In Morocco, as elsewhere, certain words must be avoided on certain occasions. Thus the Ait Sádden insist that in the morning, or in the presence of a shereef, an earthenware pan (afan or, if small, täfant) shall be called umlil or tumlilt ("white"), and an earthenware kettle (lmäun) túmlilt; ; and that in the morning a sewing-needie (täsärutt) shall be called tälmeftáht ("small opener "), a big needle (isstgyni) almeftadh

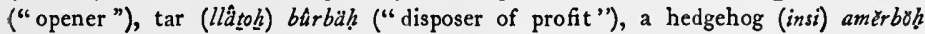
("bringer of profit"), and a fox (ib'ab) wâarssbalk ("one who has no morning"). 
praise of the young man and his family; and if he nevertheless objects to the proposal, she lets the timsuttrin understand what means should be tried to induce him to give in. She may advise the young man's father to send a shereef to persuade him to change his mind, or she may recommend making 'ar upon him. In the latter case the young man's father, accompanied by another man, by preference the $f q \tau$ of the village or the chief of the huntsmen (Yssęh nắrrma), goes very early in the morning outside the house of the girl's family and secretly sacrifices there an animal. This is not meant as a present, but as a means of compulsion, ${ }^{1}$ and the animal is consequently given away by the girl's father, who understands whence it came. If he at last is willing to give his daughter in marriage to the young man, his wife informs the latter's family about it, and the marriage arrangements now begin in earnest.

The young man's father and some respected friends of his, or, as is often the case, the latter alone, pay a visit to the girl's father, who, in their honour, gives a feast with many invited guests. These negotiators are collectively called lěmṣ̌̂htst. After eating, they mention their errand, and the bride-price (ssdaq) is discussed. The host states the sum he wants for his daughter, one of the lemşęht objects to it as being too high, but after some bargaining an agreement is arrived at; no fâtha, however, is made on this occasion.

$1 L-\bar{a} r$ acts as a means of compulsion because it is considered to transfer a conditional curse to the person on whom it is made (see Westermarck, ' $L$ 'âr, or the Transference of Conditional Curses in Morocco,' in Anthropological Essays presented to E. B. Tylor [Oxford, 1907], p. 361 sqq.). 
Even though the young man's father himself be present, the bargain is carried on by some of the other men; and if he is known to be an excitable person, he is persuaded not to come at all. After the negotiations are ended, he entertains the lemsel $h t$ in his house with a good meal, and the day is fixed for another visit to the girl's father. The amount of the ssdaq is then somewhat reduced by the lemmsech ht claiming a "commission," which is never received by them, but simply deducted from the sum to be paid. This "commission" may be only four or five dollars, but it may also be ten or even twenty. On this occasion part of the ssdaq is paid to the girl's father, though it may be only a few dollars, and he entertains his guests, among whom are also the leading men of his own village, with a meal. After this fâtha is made, one of the lemssẹht calling down the usual blessings; and from this the whole ceremony has got the name lfât tha. The presence of the young man's father is not necessary.

Although the matter is now settled there is still a formal betrothal made at the so-called asgiurt, which takes place some time afterwards-it may be a few days only, or it may be even a whole year-when the young man's father is prepared to pay the rest of the ssdaq and other necessary expenses. A visit is then again paid to the girl's father by the lemsệht, who are this time accompanied not only by the young man's father, if he cares to go, but by his mother, brothers, and sisters, and other men and women from his village whether they be his relatives or not. They take with 
them a considerable quantity of flour and salt butter, a live sheep, one or two loaves of sugar, a packet of candles, some henna, a cotton kerchief (dlhtann), and a chemise (ttsâmir). The sheep is slaughtered on their arrival; food is prepared by the women of the party, assisted by those of the girl's family; and in the evening a meal is served, to which are invited sometimes a few men of the village only, sometimes a large number of people, including women and children. After the meal a man who is related to the girl-not, however, her father, whom she avoids during these days-goes to her and suggests that she shall appoint him to be her luhîl (from the Arabic $l-\bar{u} k \hat{\imath} l$ ), or deputy, and between him and the man whom her betrothed has previously chosen as his $l u \underline{h} \hat{l}^{1}$ the following dialogue now takes place:

The young man's luhîl (A) calls out to the girl's luhîll: A flạn, a flän, a flạn, "O so-and-so, $\mathrm{O}$ soand-so, $O$ so-and-so" (mentioning the name of the girl's father, in whose place the girl's luhîl is acting). The girl's lukîl (B) answers: $N^{\prime} a m$, niam, n'am, "Yes, yes, yes."-A : D.üf lláh, düf lláh, düf llàh, " [I am] the guest of God, [I am] the guest of God, [I am] the guest of God."-B : Marhăbd, marhăbá, marhăbd düf llahh, "Be welcome, be welcome, be welcome guest of God."-A : Tilabt lek, tlabt lek, tlabt men allahh u ménněk, "I have asked you, I have asked you, I have asked from God and from you."-B : A'têt lek, a'têt lek, a țêt lek ila tqbel Yárti, "I have given

1 The luhil, however, is not always chosen by the young man or girl whom he represents, but his part may, without special appointment, be taken by some man who knows the formalities of the ceremony. 
you, I have given you, I have given you if you accept my condition."-A : Qbelt, qbelt, qbelt $\hat{u}$ rdit, "I have accepted, I have accepted, I have accepted and agreed." B : Mît 'abd, "A hundred slaves."-A : Neam, "Yes." -B : Mîat "öuda, "A hundred mares."-A : $N^{\mathrm{c} a m}$, "Yes."-B: Mîat nâja, "A hundred ewes."-A : $N^{\mathrm{c} a m}$, "Yes."-B: Mîat bégra,"A hundred cows."-A: $N^{e} a m$, "Yes."-B : Mîat b́dgla, "A hundred mules."-A : Neam, "Yes"; and so forth. After this the money is counted out, but a small portion of the ssdaq may still be left unpaid till the bride is fetched from her home, in case some reliable person undertakes to stand security. A man now fires off his gun as a signal for the three consecutive tiğŭratitin, or quivering sounds, made either by one of the women or by three simultaneously, which complete the ceremony. It is from this quivering noise, which the Ait Sádděn call asgĥurt, that the whole ceremony has got its name.

Among the Ait Ndēr parents choose wives for their sons without their knowledge. The son hears of the news from others, unless his own suspicion has led him to find out the truth. If he has no objection to the match, he lets things take their course; whereas in the opposite case his parents will hear of his dissatisfaction from some friend, to whom he also perchance has mentioned the girl he wishes to marry. Among the Ait Nderr the lads and girls of the same neighbourhood are well acquainted with each other, and it may be that the girl whom the young man wants for wife has already 
become enceinte by him. A son never mentions to his parents his desire to marry; he may speak about it to a friend, who then makes his father aware of his wishes, but in most cases he is even ashamed of doing this. Yet he is not married against his own will. It is different with a daughter; she is informed of her future marriage by her mother, and is obliged to obey.

Before the parents of the young man make their choice, the mother visits one or more tents in which there are marriageable girls, to look at them and see how the family lives. When she has found a girl whom she regards as a suitable partner for her son, the father in his turn goes to the tent to make investigations for himself. If he also is satisfied with the girl, he asks her father to come with him to a place outside the village where he makes the proposal. The girl's father may at once show his inclination to give his daughter in marriage, but often enough he refuses to do so in the beginning, saying as an excuse that her mother does not want it. But though the proposal be not accepted, the young man's father does not give up hope. $\mathrm{He}$ is likely to come back accompanied by two other men, and if necessary he will do so time after time. To give more weight to his request he asks a shereef to go with him, and in many cases he sacrifices an animal as 'ar outside the tent of the girl's father to force him to give in. When the latter appears more or less favourable to the proposal, the bride-price, which has not hitherto been touched upon, is discussed in the presence of 
friends. The girl's father asks first how much the other party is willing to give; he, of course, finds the sum which is mentioned too small, and names a higher price. The friends present try to mediate, and the price will be fixed between the sums suggested by the two parties, or else the negotiations may come to a sudden end. If the proposal is accepted, the men of the young man's village visit his father's tent to give their blessings and good wishes. They are entertained with food, and so are, of course, the friends from other villages who on that and following days come there for the same purpose.

Subsequently the young man's father, accompanied by some five or six friends, his wife, and another woman, takes to the girl's parents a sheep, a mudd or more of flour, a jar (ágssi) containing four or five pounds of salt butter, two loaves of sugar, and some salt, candles, and fuel. They are welcomed by the girl's father, whereas her mother, pretending to be averse to parting with her daughter, does not welcome them until she has been appeased by some money. The two women make a fire and prepare a dish of aftal (sčksu) with butter, while the young man's father slaughters the sheep and cuts up the meat, and then invites some of the married men of the village to come and join in the meal which is to be served in the tent. Before, or sometimes after, the meal the young man's father or, if he does not know how to conduct the ceremony, some other man whom he appoints to represent him, stretches out the palms of his hands for fâtha, 
and the other men follow his example. Then a dialogue takes place between the two fathers, very similar to that at the asgiurt of the Ait Sádden, the girl's father claiming 200 mares, ewes, cows, goats, and male and female slaves for his daughter, and the other party consenting to these conditions. Blessings are called down on everybody concerned, after which one of the women makes a quivering noise, and one of the men fires off one or two shots with his gun.

The Brâber of the Ait Warain like to marry their children early, even before they have arrived at puberty, partly to keep them from temptations, and partly to increase the strength of the family by having children at a young age. If a son is married in boyhood, he naturally has no voice in the matter; otherwise he may ask a friend to inform his father, or his sister to inform their mother, that he wants to wed a certain girl. If the father is opposed to the match, the son shows his dissatisfaction by refusing to do what he is asked - for example, to tend the cattle or plough - under the pretext that he is unwell, or even by robbing the father of some corn, or money, or a sheep. Should the father resent this by beating the lad, it may happen that the latter shoots him; and in such a case there will be no blood-revenge if the murderer is an only son, or if he has not more than one brother, who naturally would not like to be left alone through avenging his father's death. In short, the grown-up son will himself choose his wife, whereas a daughter must accept the man to 
whom her parents decide to marry her, the mother informing her of their decision.

If there is an agreement between father and son as to the choice of a girl, the former goes to her father to discuss the matter. Should he refuse to give his daughter in marriage, the young man's father asks four shereefs to speak on his behalf, and a second refusal would now be looked upon as bad and would hardly occur. After this preliminary arrangement he pays another visit to the girl's father, this time accompanied by his wife and four shereefs, and taking with him two animals loaded with wheat, a large jar (tdidurt) containing some thirty pounds of salt butter, and a sheep. On his arrival he slaughters the sheep as 'ar to make the earlier promise more binding; but this does not prevent the mutton from being served with séksu at a meal in which the neighbours also partake as guests. On this occasion the bride-price (ssdaq) is discussed and, after the usual bargaining, settled with the aid of the shereefs. The women make a quivering noise, tililau, which name is therefore given to the whole ceremony; and the girl's father asks one of his friends to fire off his gun as announcement and confirmation of the agreement. Fâtha is frequently, but not in every case, made on this occasion.

Among the At Ubáhți parents do not marry their children before the age of puberty, but all marriages are nevertheless arranged by them. If the father and mother disagree on the choice of a wife, the mother, I 
was told, manages to carry her wishes through. Accompanied by a female relative she pays a visit to a tent where she thinks there is a suitable girl, taking with her some loaves of bread as a present to the family; and if her expectations are not fulfilled, she goes to another tent on the same errand. In case the young man wants to marry a certain girl, he mentions it to some woman of his family, who then informs his mother about his inclination; but if the mother takes no notice of it, the son is said to have no voice in the matter.

After the girl has been chosen, the young man's father sends four or five respectable men from among his relatives or friends to the girl's parents to act as negotiators. These men, who are called imahdâbèn, tell her parents, both of whom are present on this occasion, that they come on behalf of so-and-so, to propose that they should give their daughter in marriage to his son. The parents express their fears that the young man will not make a good husband, but is likely to beat his wife; to which the imahdâben reply that they are quite mistaken-he is a nice fellow, and they ought not to refuse so good a proposal. At last the parents consent, fâtha is made, and the company have a meal together.

The young man's father then goes to the tent of the girl's parents, accompanied by the imahdâben and a few other men, including the $f q i$ of the village, if there is one. He takes with him a sheep, which he slaughters at the entrance of the tent; this is an 'ar-sacrifice, 
but the animal is nevertheless afterwards eaten by the company. They are received with greetings of welcome, after which business is discussed, though in a quite formal manner. The girl's father asks the young man's father how much he is willing to pay for his daughter. The latter answers that he will pay any sum which is demanded. The girl's father invariably claims a hundred dollars and a female slave, to which the young man's father consents without any intention to pay the whole of this price. When he is counting out the money-either now, if he has brought it with him, or otherwise on a later occasion-he stops, say at fifty dollars. The girl's father tells him to go on and finish the sum; but now the imahdâbeèn step in, one saying, "I have got ten dollars as my share"; another, "I have got five as mine," and so forth. Then nothing more is claimed. The statements made by the imalndâbenn are all sham; they have previously arranged with the girl's father how much is actually to be paid, and hence the other man knows where to stop. But if the girl is of a good family, the hundred dollars may have to be paid in full.

Subsequently the young man's father again visits the father of the girl, taking with him presents consisting of three live sheep, of which he slaughters one on his arrival, a jar (táqbu $\zeta_{t}$ ) of salt butter weighing from four to six pounds, one or two loaves of sugar, some green tea, a pound of candles, thirty tigordîyin of barley and ten of wheat, a Fez mudd of ground wheat, and whatever money still remains to be paid. $\mathrm{He}$ is accom- 
panied by some ten men and a few women from among his relatives, the business of the latter being to prepare the great meal which is now served at the tent of the girl's family, and in which also neighbours join as invited guests. A formal betrothal ceremony takes place, essentially similar to that of the Ait Sádden and Ait $\mathrm{Nder}$, and one of the women makes a quivering noise, timuYit, which is also the name given to the ceremony in question. On the return of the young man's father and his party, a feast called lbârwih is held at his tent the same day and the following day also. The men of his own and neighbouring villages come there to bestow their blessings on the young man and his family. There is much powder-play, and the guests are entertained with good food. But the young man himself is not present on this occasion. He avoids his father from the day when the arrangements for his marriage commence, and does not see him again until after the wedding, when he kisses his head. All this time the son neither eats nor sleeps in his father's tent.

I was told that in the neighbouring tribe At Zihri it happens that parents marry their sons while still quite young to women who are so much older than these boy-husbands that they might be their mothers. The wife looks after her husband as if he were her son, and when he arrives at the age of puberty his wife has long ago become a mother. Indeed, the husband and his wife's eldest son may be of nearly the same age, but the latter, nevertheless, calls his mother's husband "father" 
and is called by him "son." The reason for these marriages is the desire to have grown-up children as early as possible on account of the prevalence of bloodrevenge. My informants were men from the At Ubáhtí, but their statements substantially agree with those given by M. Mouliéras. ${ }^{1}$

Among the Ruâfa of the Ait Wäryâgäl marriages are arranged by the parents of the parties, often enough before the children have reached the age of puberty. The wedding, however, is only held when the young couple are able to set up their own household ; till then they live in their respective homes without having intercourse with each other or even meeting. But when the means of the parents allow it, they have their wedding and settle down together while they are still children. Here also early marriages result from the desire for sons, who are of extreme importance in a society where the blood-feud is rife; moreover, if a man at his death leaves behind daughters only, his brothers or nephews will take possession of his house. If the young people are cousins or neighbours, they are naturally acquainted with each other; but this is not the case otherwise.

The mother of the young man or boy meets the mother of the future fiancée at the women's market to make an informal proposal. If the latter is in favour of the match, she says that the affair should be discussed

1 Mouliéras, Une Tribu Zénète anti-musulmane au Maroc (les Zkara) (Paris, 1905), p. 91 sqq. 
by the two fathers, who soon afterwards come together at the men's market, both accompanied by friends. After they have partaken of some food brought by the young man's father, one of his friends asks the girl's father to give his daughter in marriage to the other man's son. He answers that he will do so if his conditions are agreed to. A sum of money is mentioned, as also certain quantities of wheat, beans, oil, and so forth, which are demanded for the girl. After some bargaining an agreement is arrived at, the young man's father gets up and kisses the girl's father on the head, the latter does the same to him, and the other men follow their example.

Some days after this meeting the young man's mother, accompanied by two or three other women, pays a visit to the girl's mother, taking with her bread wrapped up in a kerchief, amendir, which name is also given to this present. Later on the young man's father and his kinsfolk-men, women, and childrentake to the girl's family the so-called amehri, consisting of raw meat, bread, and oil, the men firing off their guns and the women making a quivering noise (sriwriwen). After a meal, made on the bread and oil, a formal betrothal takes place, with exaggerated claims set forth by the girl's father, and nominally consented to by a $f q \bar{\tau}$ acting on behalf of the other party. Fâtha is then made; and there is much powder-play, sriwriwen, and dancing by the unmarried girls.

If a man wants to marry a certain girl, and her 
father is opposed to the match, he can compel him to give in by sacrificing a sheep as 'ar outside his house. But this is not held to be a good method of procuring a wife, since it is believed that some misfortune is likely to befall a person who induces another to grant his request by making ' $a r$ on him, the curse in such a case affecting the petitioner and not the individual appealed to.

Among the Shlöh of the Ait Támèldu, when a young man wants to marry, he may choose his wife from among the girls of his own village, with whom he is of course acquainted since childhood; or he may prefer a girl from another village, where he has some friend whom he takes into his confidence. It is arranged that they together shall watch the girl recommended to him, when she goes on a visit to some shrine. The two friends hide themselves on the roadside, so that the young man can see her face and form an opinion about her walk, which is also considered a matter of importance. If he is pleased with her appearance and, besides, hears that she is skilful at weaving and preparing food, he asks a friend to inquire of her father whether he be willing to give her in marriage. Should her parents consent, after satisfying themselves of the young man's character, the friend mentions the son's wishes to his parents, who may either agree at once or answer that they are not yet prepared for his marriage. In the former case his father requests two or three men, one of whom is the friend himself, to 
make a proposal on behalf of his son. When these men, the so-called indalabern (sing. andalb), go on their errand, they take with them a silver ornament for the girl and a large quantity of henna and dates, part of which her father distributes among his neighbours to advertise his daughter's engagement. There is no bargaining as to the dowry (amerwas), since it is fixed by custom once for all. Before leaving, the indálaben say on what day they will return with the amerwasor rather one-half of it-and on this latter occasion the marriage contract is sealed by a fatha conducted by the fqi, after a meal has been partaken of. The indalaben then inform the girl's father of the day when the wedding is going to take place.

A girl cannot oppose the match arranged by her parents, but if her father is dead she herself appoints her lukîl. Again, if a son is getting old without showing any inclination for marriage, his parents may take the first step, and under such circumstances he would comply with their wishes.

In addition to the ceremonies just described, a written contract of marriage is frequently drawn up by two 'ădûl, or notaries, in the presence of witnesses, either before the wedding, when the sdaq or part of it is paid, or, as is the case, for example, in Andjra, on the day when the bride is brought to her new home. This document itself is called șdaq. But, as has been already said, it is not required to make the union valid; and in many Berber tribes the contract of marriage is hardly 
ever reduced to writing, the ceremony of fâtha being the only confirmation of it.

In Morocco marriages between cousins on the father's side are common both among Arabs and Berbers. ${ }^{1}$ A man is even held to have a certain right to his cousin's hand. In Andjra I was told that he ought to be asked if he wants to marry her, before she is given away to anybody else, and that, if this is not done, he is entitled to prevent her marriage even on the day of the wedding, by forcibly removing her from the bridal box; and among the Ulâd Bu-'Ǎzîz a man who has contracted marriage with another man's paternal cousin can be compelled by the latter to give her up if he is compensated for his expenses, but only on condition that she has not yet settled down with him. In the Rif instances are known in which an uncle who has married his daughter to another man has been killed by his nephew. The sdaq paid for a paternal cousin is often smaller than usual, although it also happens that a man tries to prevent his nephew from marrying his daughter by making his claims excessive.

Marriages between paternal cousins are popular because they keep the property in the family, ${ }^{2}$ and, especially in shereefian families, because they preserve the blood pure. They are also said to be conducive to

I Cf. Fischer, 'Zum Wortton im Marokkanischen,' in Mittheilungen des Seminars für Orientalische Sprachen an der Königl. Universität $\approx u$ Berlin, Jahrg. II. Westasiatische Studien (Berlin \& Stuttgart, 1899), p. 282 ; Doutté, op. cit. p. 339.

2 For a similar motive among the ancient Arabs, see Kitäb al-ağanni, ed. Būlāk, viii. II 3 , quoted by Goldziher, 'Endogamy and Polygamy among the Arabs,' in The Academy, xviii. (1880), p. 26. 
domestic happiness. Li ḩą bent 'ámmu 'ăyyid mẹ̆n ǵlmu, "He who marries the daughter of his father's brother celebrates his feast with a sheep from his own flock" - he knows the sheep he slaughters. Or: whilst marrying a strange woman is like drinking water from an earthenware bottle, marriage with a cousin is like a drink from a dish-you are aware of what you drink. Such a marriage also gives the husband greater power over his wife, since, if she runs away, her father or brother will bring her back; and it has the further advantage that she cannot curse her husband by cursing his ancestors without implicating herself in the curse. It confers religious merit on a man to marry his cousin - by doing so he will not be punished on the day of the Resurrection ; and at the same time it is a kind of duty. Li yệrfed zebbâlats n-näs yệrfed dyâlu, "He who carries away the dunghills of the people carries away his own "-it is not right of a man to leave his own cousin unmarried by taking another woman for wife.

Yet cousin-marriages are also considered to have their drawbacks. At Fez I was told that they easily lead to quarrels between the husband's and wife's families, both of whom want to interfere in the married life of the couple $;^{1}$ hence, when girls who want to marry visit the tomb of Sîdi Mbârặk ben 'ăbåbủ outside the gate Băb l-Gîsa, they address the saint with the

1 The poet of the Mu'allakāt gives in his testament the following advice to his children :- "Do not marry in your own family, for domestic enmity arises therefrom" (Kitab al-ağanz, ix. 185, quoted by Goldziher, loc. cit. p. 26). As Wellhausen (loc. cit. p. 437) observes, the enmity spoken of in this passage probably means "Zwisten zwischen den Familien des Mannes und der Frau, die durch Einmischung der Schwiegereltern hervorgerufen werden." 
words, $A$ sîdi Mbârọ̣k ben 'Ăbâẩ a'têni r-râjel blạ ḥbâabû, "O Sîdi Mbârặk ben 'Abâbủ give me a husband without friends." It is a common belief that cousinmarriages make the children resulting from them weak and the family unlucky. ${ }^{1}$ A proverb says :- 'Ammak yàmmik u hâläk yáhllik u ba'ad mẹn démmäk la yẹ́blik, "Your father's brother will make you blind and your mother's brother will make you destitute, and keep away from your blood that it shall not visit you with misfortunes." A Berber from the Great Atlas once said to me, "How can a man love a woman with whom he has grown up from childhood ?" And I have heard a similar argument adduced against marrying a girl from one's own village. Where I was staying in Andjra a man was betrothed to a cousin who was living in an adjoining cottage, and I heard the opinion expressed that it was shameful he should marry a girl whom he constantly saw. It was said that not even cousins should see much of each other before they married.

The idea that a man has a right to wed his bint amm, or paternal cousin, is common in the Muhammedan world, ${ }^{2}$ and also prevailed among the ancient

1 It was also the opinion of the ancient Arabs that the children of marriages between relatives are weakly and lean. Thus a poet, in praising a hero, says of him :- "He is a hero not borne by the cousin (of his father), he is not weakly ; for the seed of relations brings forth feeble fruit." In a proverb of Al-MeydānI (ii. p. 250) it is said, "(Marry) the distant, marry not the near (in relationship)." See Goldziher, loc. cit. p. 26; Wilken, Das Matriarchat (das Mutterrecht) bei den alten Arabern (Leipzig, 1884), p. $5^{8}$ sq.

2 According to Burckhardit (Bedouins and Wahábys, pp. 154, 64 sq.), "all Arabian Bedouins acknowledge the first cousin's prior right to a girl; whose father cannot refuse to bestow her on him in marriage, should he pay a reasonable price; and that price is always something less than would be demanded from a stranger. . . . He is not obliged to marry her, but she cannot, without his consent, become the wife of any 
Arabs ${ }^{1}$ Wellhausen observes that their cousin-marriages served the purpose of strengthening the kinship tie, ${ }^{2}$ and that the same was the case with other marriages contracted inside the same village. ${ }^{3}$ In Morocco, marriages between members of the same village are encouraged by the Berbers of the Rif, who, in order to keep away alien elements from the community, deny the right of inheritance to a woman who leaves her village; yet marriages between persons belonging to different villages are not rare among them. In most parts of Morocco such unions are of frequent occurrence. Much less frequent, of course, are marriages between members of different tribes $;^{4}$ but even Berbers and

other person. If a man permits his cousin to marry her lover, or if a husband divorces his runaway wife, he usually says, "She was my slipper, I have cast her off." See also Burton, op. cit. ii. 84. Among the peasants of Palestine, if a girl is given in marriage to another man, her cousin even considers himself entitled to carry her away by force from the bridal procession (Klein, loc. cit. p. 84. See also Robinson Lees, op. cit. p. 121 ; C. T. Wilson, op. cit. p. 107 sq.; Jaussen, Coutumes des Arabes au pays de Moab, p. 45 sqq.). For cousin-marriages in modern Egypt, see Lane, Modern Egyptians, p. 170 sq.; Idem, Arabian Society, p. 227; Klunzinger, Upper Egypt (London, 1878), p. 196. For similar marriages in Algeria, see GaudefroyDemombynes, op. cit. p. 7. See also Burckhardt, Arabic Proverbs (London, 1830), p. 18I ; Snouck Hurgronje, Mekkanische Sprichwörter und Redensarten (Haag, 1886), p. 17 .

I Robertson Smith, Kinship and Marriage in Early Arabia (Cambridge, 1885), pp. 82, 138, 164; Wellhausen, loc. cit. p. 436 sq.; Wilken, op. cit. p. 59. Among the ancient Arabs, "the beloved one is called, indeed, even when she stands in no position of relationship to her lover 'bint 'amm' (cousin), and the father-in-law, although not the uncle of his son-in-law, is called "amm' (uncle)" (Goldziher, loc. cit. p. 26). Among the present Bedouins of Arabia bint 'amm " in polite phrase signifies a "wife"" (Burton, op. cit. ii. 84).

2 The Arabic history of the Persian king Ardeshir tells us that, among other maxims of morality, he gave the following advice to his lawyers, secretaries, commanding officers, and husbandmen : "You may marry among your near relations, for the sympathy of kinship is kept alive thereby" (Goldziher, loc. cit. p. 26).

3 Wellhausen, loc. cit. p. 437 sq.

4 Chenier, who wrote his book on Morocco towards the end of the eighteenth century, says (The Present State of the Empire of Morocco, i. [London, 1788], p. 130) that "the tribes dispersed over the country usually confine their marriages each 
Arabs sometimes intermarry when they come into much contact with each other. I was told that among the northern Brâber not a few men have wedded women from neighbouring Arab tribes or from Fez, whereas it is very rare that one of their women is married to an Arab.

Strict endogamy, however, is not unheard of in Morocco. The At Zíhri, who are known for their exclusiveness, are reported to marry only between themselves and also to refrain from all sexual intercourse with strangers $;^{1}$ and among the Ait Hăssan, a fraction (táqbilt) of the Ait Waráin, no stranger is even allowed to be present at a wedding. There are, moreover, prohibitions of intermarriage referring to some special tribes, subdivisions of tribes, or villages, in connection with other peculiarities in their social relations. Thus there is so-called tada, or brotherhood, between the Infdiak (Fțuâka) and Igliwa in the Great Atlas, which implies that no marriage is allowed between them, and also that if a member of one of these tribes takes refuge with the other tribe, he cannot be touched. I found the same institution among the Brâber of the Ait Ndêr, Ait Yúsi, and Ait Sádděn, who call it tádda; but the

within itself, seldom intermarrying with other tribes." In the Hlot and Tliqq, according to Messrs. Michaux-Bellaire and Salmon ("Les Tribus arabes de la vallée du Lekkoûs,' in Archives marocaines, vi. [1906], p. 232), "les mariages se contractent généralement entre gens du même douar, ou au moins de la même fraction. Il arrive cependant quelquefois, surtout chez les gens riches, qu'un mariage est contracté entre gens de deux fractions différentes de la même tribu. Ce qui est infiniment plus rare, c'est le mariage entre gens de deux tribus différentes." See also Michaux-Bellaire, 'Quelques tribus de montagnes de la région du Habt,' in Archives marocaines, xvii. (1911), p. 127.

${ }^{1}$ Cf. Mouliéras, Une Tribu Zénète anti-musulmane au Maroc (les Zkara), p. 82. The statements above were made to me by men from the At Ubáhti. 
duties it imposes are among them more numerous than those I heard of among the Shloh. Besides the marriage taboo and the inviolability of refugees there are strict prohibitions of the use of bad words, the telling of lies, and the commission of any crime whatsoever, as also of selling and buying, between members of the groups to which the tad $d a$ refers; and the transgression of any of these rules is supposed to entail some grave misfortune. The people belonging to communities between which there is tdda are said to be more than brothers to each other. If a person from one of them visits the other he is received with the greatest hospitality, presented with any food he likes, respected as highly as a shereef, and appealed to as an arbitrator by quarrelling parties; yet the tadda does not imply the duty of mutual assistance in war. Since ancient times there is táda between the Ait Sádden and the Ait Wälläl belonging to the Ait Nder ; it is said to have been instituted by a saint called Sîdi Būteyib, who is also supposed to inflict severe punishments on those who break its rules. Within the tribe of the Ait Yúsi there is tada between the $i g g_{s}{ }^{1}$ Ait Yăhya u Yusf (consisting of five villages) in the section ( $\left.\dot{r} r b a^{\circ}\right)$ Ait Ärrba' and the iğsss Ehinajen (consisting of two villages) in the rrba Ait Mahhluf; between the $i g s s$ Aid Daud (consisting of four villages) in the $\dot{r} r b a^{e}$ Ait Hălli and the village Ait Händ $\mathbf{u}{ }^{e}$ Alli among the Ait Măhluf ; and between the villages Ait

1 Ig̣șs (plur. ig̣san; literally " bone") is a subdivision of a larger social unit called $\dot{r} r b a$ (plur. lárbá; literally "quarter"), which itself is a division of a táqbilt, or tribe. An igsss consists of a number of villages or sometimes of a single village only, inhabited by persons who are relatives on the father's side. 
Bráhim and Ait Zzarhum, both belonging to the Ait Măhlûf. In olden times there was also táda between the whole tribes of the Ait Yúsi and Ait Sáddern, but this has long ago come to an end; yet even now persons from these tribes address each other as $u$-táda (masc. sing.), ult-táda (fem. sing.), ait-táda (masc. plur.), or ist-táda (fem. plur.).

It is a common practice in Morocco, among both Arabs and Berbers, that a man marries his deceased brother's widow, so that her children and property shall not come under the influence of a man outside the family. He is not, however, obliged to marry her, nor is it necessary that his offer to do so should be accepted. ${ }^{1}$ According to Muhammedan law, as we have seen, a widow or divorced wife has, under ordinary circumstances, a right to dispose of her own hand, but among some of the Berbers, both in Morocco and Algeria, ${ }^{2}$ she is in her father's power as fully as she

I Cf. Doutté, op. cit. p. 339 ; de Segonzac, Voyages au Maroc 1890-190I (Paris, 1904), p. 127. Of the position of a widow among the Arabs of Moab M. Jaussen (op.cit. p. 48) writes :-- "En principe, elle doit devenir la femme du frère du mari, qui a droit sur elle, et très souvent l'épouse. Si la veuve ne veut absolument pas, elle retourne chez son père, même si elle appartient à une autre tribu." Among the Aeneze, according to Burckhardt (Bedouins and Wahábys, p. 64), "if a young man leaves a widow, his brother generally offers to marry her; custom does not oblige either him or her to make this match, nor can he prevent her from marrying another man. It seldom happens, however, that she refuses; for by such an union the family property is kept together." Among the pagan Arabs a widow was inherited by her brotherin-law or her step-son (Robertson Smith, op. cit. p. 86 sqq.; Wellhausen, loc. cit. p. 455). Islam, on the other hand, forbade men to inherit women against their will (Koran, iv. 23), and to marry their step-mothers (ibid. iv. 26), but approved of marriage with a brother's widow.

2 Hanoteau and Letourneux, La Kabylie et les coutumes kabyles, ii. (Paris, 1873), pp. $151,156,159$. 
was before her marriage. It was pointed out to me that among the Ait Nderr her father, or, if he is dead, her brother, can again sell her to any man he chooses, whereas at $\mathrm{Fez}$ it depends upon the woman herself to accept or refuse a proposal.

In certain exceptional cases, however, a man may, as a matter of course, and without payment, marry his brother's widow; or, if the dead man has no brother, his widow may be sold by the women of his family, his mother in the first place and in the next his sister or daughter. This happens in the case of a married woman who has run away from her husband and compelled the other man to marry her. The Brâber have a custom which gives this peculiar privilege to married women. Among the Ait Sádden, for instance, a woman who does not like to remain with her husband may fly to another man's house or tent, and embrace the pole supporting the roof or one of the vertical tent-poles or, if there is no such pole, take hold of the handmill and turn it round as if she were grinding. Then the owner of the house or tent is obliged to marry her and pay five hundred dollars to the abandoned husband. If he is unable to pay this sum and his relatives cannot help him, he may by means of " $a r$ sacrifices collect " ransom-money" (lı $f \underline{d} \underline{\hat{\imath}} \hat{t})$ from others, or he may leave his village and the neighbourhood altogether, or he may induce a shereef and some other men to go to the forsaken husband's dwelling and perform there the so-called amiârqab (the Arabic $\left.t^{\prime} a r g i b a\right)$, the most awful of all 'ar-sacrifices, consisting 
in cutting the sinews of a bullock's hocks. ${ }^{1}$ Otherwise there is likely to be a feud. If the injured man and his village are not strong enough to fight the new husband and his party, he invokes the assistance of another village by making powerful ' $a r$ on it - he sacrifices a bullock as amârqab at the door of its mosque, or takes his daughter there dressed in an old tent-cloth (ahläs or tahläst), or rides there with an old tent-cloth round the neck of his horse, or removes the saddle from the horse and puts it there upside down. But it may also be that the injured man, instead of having a fight, kidnaps a woman belonging to the village to which his wife has fled and then runs away with his booty to another tribe. In such a case the husband, father, or brother of the kidnapped woman, in order to get her back, will insist upon the payment of the five hundred dollars or, if the new husband and his family have left the place, will collect the necessary ransom from the other villagers.

Similar customs are found among the Ait Yúsi, Ait Waráin, Ait Nderer, and other Brâber; but the compensation to be paid to the former husband varies considerably in different tribes and even in different divisions of the same tribe. Among the Ait Waráin it was said to be two hundred dollars. The Ait Yúsi and Ait Nder have agreed upon twenty-one dollars if the woman has fled from the one tribe to the other,

1 See Westermarck, in Anthropological Essays presented to E. B. Tylor, p. 365 sq. The reason for cutting the sinews of the bullock's hocks seems to be to give the animal the appearance of a suppliant. Sometimes the victim is a horse or, among the Ait Yúsi and Beni Mgild, a camel. 
and the Ait Yúsi and Ait Sádděn upon seventy dollars, though not long ago the price was only half this sum. If a married woman from the Ait Nder runs away to the Zémmur, her husband can claim a cow with a calf, and if she flies to an Arab tribe thirty-five dollars; whereas other Brâber, as the Ait Sádděn and Ait Yúsi, have made no agreement of this kind with their Arab neighbours for the simple reason that none of their women would think of preferring an Arab to a man of her own race. Within the tribe of the Ait Yúsi the price fixed by custom varies in different lárba', or quarters, of the tribe. It is fifty dollars in cases arising between the Ait Ärrba' and Ait Măhlûf; eighty-six for those between the Ait Hâlli on the one hand and the Ait Ärrbae, Ait Măhluff, or Ait Frígwu on the other; a hundred for those between the Ait Ärrba' and Ait Frig'u; and one hundred and twenty for those between the Ait Mes'öúd $u$ 'Ăli and the Ait Ärrba', Ait Măhluff, or Ait Frig'u. Within the Ait Ärrba' the price is one hundred and fourteen dollars. All these detailed stipulations show that the practice in question must be a fairly common one. I knew an old man of good family from the Ait Yúsi who in the course of his life had been compelled to marry three run-away wives. The compulsion is the same whether the man to whom the woman has fled be a bachelor or a married man, and whatever be the number of his wives.

This singular custom is based on the idea that some grave misfortune would befall the man if he did not wed 
a woman who in the said manner took refuge with him. By taking hold of the pole of his dwelling or turning round his handmill, she makes ' $a r$ on him, that is, transfers to him a conditional curse. But though superstitious fear is at the bottom of the custom, its observance is, at the same time, looked upon as a matter of honour; among the Ait Waráin a man who should refuse to marry the woman would be called a Jew. It is also held necessary that he should have sexual intercourse with her the first night. There is no further ceremony attending these marriages. 


\section{CHAPTER II}

THE ȘDĀQ AND OTHER PAYMENTS-THE TROUSSEAU

According to Muhammedan law, the giving of a dowry is necessary for the contraction of a valid marriage. ${ }^{1}$ It is true that a man may legally marry a woman without mentioning a dowry, but in such a case the law presumes a consideration in her favour by virtue of the contract itself. ${ }^{2}$

As to the amount of the dowry there is no maximum fixed by law, though excessive dowry is considered improper both by the Sunnis and Shr'ahs. As the minimum the early Hanafi lawyers fixed ten dirhems, equal to about four or five shillings, whereas the Mãlikis, inhabiting a poorer and less populous country than that in which the Hanafi doctrine flourished, regarded three dirhems as the lowest sum which could be given by way of dowry; but these minimums have been abandoned long ago. ${ }^{3}$ It is not necessary that

1 Sidr Halrl (Muhtașar, $\$ 19$, Russell and Abdullah al-Ma'mun Suhrawardy, ' $A$ Manual of the Law of Marriage' from the Mukhtasar of Sidt Khaltl, London, s.a. p. 5) says that the constituents of marriage are a walt, a dowry, spouses free from legal impediments, and the formula.

2 Ameer Ali, Mahommedan Law, ii. (Calcutta, 1908), p. 472 sq.

3 Ibid. ii. 473 sq.; Sautayra and Cherbonneau, Droit musulman, i. (Paris, 1873), p. 95; SId Halil, op. cit. $\$ 168$ (p. 61). 
the dowry should be paid in money. Sidi Halil points out that it is lawful to contract a marriage for a dowry consisting of household furniture, or a certain number of camels or slaves or the like. ${ }^{1}$

As there is nothing in the Koran or in the traditions tending to show that the whole of the dowry must be paid prior to the consummation of the marriage, later jurists have held that only a portion of it should be considered payable at once or on demand, and the remainder within a certain stipulated period or on the dissolution of the contract, whether by divorce or the death of either of the parties. ${ }^{2}$

The dowry is in legal treatises called mahr or sadaq. Originally, however, these words meant different things. The mahr was the purchase sum paid to the father or guardian of the woman at her betrothal, whereas the sada $q$ was the gift offered to the bride by the bridegroom at their wedding. But under Islam the distinction between mahr and sadaq disappeared-a fusion which was prepared by the fact that already in preMuhammedan times the mahr had, at least occasionally, been given to the wife as her property. ${ }^{3}$

In Morocco the dowry is called $s d a q$ or $s d a q$, sometimes $s d a q$, by the Arabic-speaking population ; ssdaq or ss daq (Ait Waráin) by various tribes of the Brâber ; ss $\underline{d a q}$ by the Ruâfa of the Ait Wäryâgäl, and ámerwas by the

1 Sidr Halrl, op. cit. $\$$ I 54 (p. 55).

2 Sautayra and Cherbonneau, op. cit. i. 98 sqq. Ameer Ali, op. cit. ii. 482 . STdi Halrl, op. cit. $\S \S 156$ (p. 56), 173 (p. 62).

3 Robertson Smith, Kinship and Marriage in Early Arabia (Cambridge, 1885), pp. 76, 78, 91. Wellhausen, 'Die Ehe bei den Arabern,' in Nachrichten von der Königlichen Gesellschafi der Wissenschaften zu Götingen, 1893, no. I1, p. 433 sq9. 
Shlöh of the Great Atlas and Sas. At Fez it is also called náqda and, by scribes, mhar. But níqda, or naqd, properly means only the portion of the sdaq which is paid at once. ${ }^{1}$ In Northern Morocco, at least, this portion is called nûss mqáddam, "advanced moiety," whilst the remaining part is called nùsss mwáhḩar, "deferred moiety." 2

In some parts of Morocco the sdaq is fixed once for all by custom, although the amount may vary greatly even in the same tribe. This is the case among the Ulåd Bu- $\breve{A} z \hat{z} z$ in Dukkâla. In the subdivision of this tribe called Ulåd Râfa, for example, the sdaq is twenty métqal, nominally eight Spanish pesetas, whereas in some other subdivisions of the same tribe it is considerably higher, in one even as much as four hundred métqal. But within the same subdivision it does not vary and is the same whether the woman is a virgin, a widow, or a divorced wife. Among the Ulåd Bu-'`̃zîz, however, not more than one-half of the stipulated price is paid, and even this sum only if the husband dies before his wife, or if he divorces her, nothing at all being given on the occasion when the marriage contract is made. Yet there is one instance in which a much higher payment may be claimed, and that is if the husband refrains from doing his duty as a married man and divorces his wife against her will; in such a case he has to pay a so-called sdaq máy $\hat{u} f a$, amounting

1 Russell and Abdullah al-Ma'mun Suhrawardy, op. cit. p. 56, n. I referring to \$ 157 .

2 The deferred portion is in legal treaties called käl' (Russell and Abdullah alMa'mun Suhrawardy, op. cit. p. 56, n. I referring to $\$ 157)$. 
to twice the nominal sdaq, and the wife is besides allowed to take with her everything which is in the tent.

Among the Shlöh of Amzmüz the amerwas (șdaq) is invariably one hundred métqal for a virgin and fifty for a widow or divorced wife. Of this sum, however, twoand-a-half métqal are given to each of the two ' $\breve{d} d \hat{u} l$ and the same sum to the woman who makes the quivering noise. The rest is paid to the wife on the death of her husband, or if she is divorced by him ; and in the case of her death it is inherited by her children, or, if she has none, by her family.

Among the Igliwa, who are divided into five lahămas (sing. lhåms), each containing a certain number of smaller sections called ihsan (sing. ihhs), the ámerwas is the same within the ihs but differs within different ihsan. For example, in the ihss Táfga in the lhams Ait Ărrba the ámerwas consists of forty métqal, two hrâreb of wheat, the same quantity of barley, four sheep, two large jars of salt butter, and two other large jars of oil ; but this is only paid to the wife in case she is sent away by her husband or at his death. In the $i$ hs Ait Ug dat in the same lhams the amerwas consists of a hundred métqal and nothing else, and here the wife also can dissolve the marriage by paying her husband the same sum, which is not the case either in Táfga or in the ihss Isirs belonging to the same lhams. In the latter ihs the amerwas is only fifteen métqal; whilst in the fourth ihs of the Ait Arrba', called Afra, the dmerwas simply consists of an animal which the wife, if she should be 
divorced, is allowed to pick out with closed eyes from her husband's farm.

Among the Ait Támelldu the dmerwas is two hundred métqal, or sixteen dollars, if the woman is a virgin, a hundred métqal if she has been married once before, fifty if she has been married twice, twenty-five if she has been married three times, and so forth. Onehalf of the dmerwas is paid before the wedding when fâtha is made, and is spent on clothes for the woman, whilst the other half is paid at the death of the husband or if he divorces his wife. If she wants to leave her husband, the portion of it which has been already paid is not restored, but the other portion is of course forfeited. In such a case she asks the $f q \bar{\tau}$ to draw up a document stating that she is no longer married.

Again, among the Shlöh of Aglu the amerwas is invariably twenty-four Moorish dollars in the case of a virgin and twelve dollars in the case of a widow, a divorced wife, or a girl who has become a mother; but in the last-mentioned case the father of the child has previously had to pay the full amerwas unless he married the girl. The amerwas, however, is not paid even in part when the marriage is contracted, but the bridegroom produces as security a friend, whose responsibility lasts till seven days after the wedding. When this period has come to an end, the wife declares in the presence of two scribes that the money is now in the hands of her husband; but if he divorces her he nevertheless has to pay the full amerwas, which, though 
her property, is then handed over to her father, brother, or uncle, and to herself, in the presence of scribes, only in default of a near male relative. Before the wedding the man pays to his fancée's father merely a sham price consisting of some copper coins, altogether worth half-ab̌̌lyūn, or about an English penny.

Among the At Ubáhti the șdaq regularly consists of a belt (dhh̆zzam), two silk kerchiefs (țise̋nîyin), two shawls (lizârat), and a pair of slippers (lbéligat), representing a value of ten dollars, which are given to the bride on the day when she is taken to her new home. The money paid to her father which has been mentioned above is not sșdaq but tämamt, of which more will be said presently.

As a rule, however, the șdaq is not fixed once for all but varies according to circumstances. At $\mathrm{Fez}$ it is comparatively high. People who are not considered well-off may pay seventy to a hundred dollars for a virgin and thirty to forty for a widow or divorced woman, whilst the șdaq may be as much as six hundred dollars if the parents of the parties are wealthy. It is paid some time after the ceremony of fâth ha, a month or even a year, as the young man's father may wish. The payment of it takes place in different ways. The two fathers may simply meet in a mosque for this purpose, and the sum agreed upon is paid over in the presence of two notaries (' $a d \hat{u} l$ ), who now write the marriage contract; but at the present time the affair is generally accompanied with more ceremony. The young man's father gives a feast in his house, to 
which are invited male relatives and friends, as also two 'adûl. From there he sends the ' $\ddot{d} d \hat{u} l$ and some other men to the girl's father, who on the same occasion has a feast in his house. The latter asks them to join; the sdaq is paid, and the marriage contract written. The sdaq is spent by the girl's father on her trousseau.

In Andjra a poor man may pay as sdaq some ten or twenty dollars or even less, a rich man a hundred or two. One-half of the money is paid on the nhar l-kmäl, whilst the other half is paid at the death of the husband, or if he divorces his wife without good reason, or by annual instalments in the course of twenty years. With the portion of it which is paid down the girl's parents buy clothes for her, and it would be considered disgraceful if the father used anything of it for his own benefit. The clothing and other things which, besides the money, are included in the sdaq are taken to the girl's house together with the bridal box in which she is to be brought to her new home, and are taken back again on the same day. One hâyẹ̆k, however, which, as we shall see, plays an interesting part in the wedding ceremonies, is sent to the girl's house three days before with a portion of the hdîya.

In the Hiaina the sdaq is generally between fifty and a hundred dollars, though a poor man may perhaps get a wife for ten or even less. The father of the girl keeps one-half of it for himself and spends the other half in buying clothes and ornaments for his daughter, except some four or five dollars which are left to be 
paid to the wife either by instalments or at her husband's death, or if he divorces her without a good cause; but the husband may also square the debt by buying a present for his wife. The sdaq, however, must be returned if the bride is sent back because she is found not to be a virgin, or if she is divorced on account of misbehaviour.

Among the Ait Sádděn a rich man's daughter fetches a higher price than a poor man's, a beautiful girl-other things being equal-a higher price than an ugly one; but even for an unattractive girl a considerable sum may be paid if her father is a man of wealth. The ssdaq of a widow or divorced wife is generally much less than that of a virgin. A hundred dollars is a moderate ssdaq, I 30-200 a high one; 70 and 90 dollars are prices that must be avoided because these numbers are considered unlucky. As we have seen, however, the ssdaq first agreed upon is not paid in full. ${ }^{1}$ The father of the girl spends a smaller or larger part of it-as much as he likes-in buying clothes and ornaments for his daughter, keeping the rest of it for himself.

Among the Ait Warain the amount of the ssdaq depends on the beauty of the girl, her skill in weaving, and the wealth of her father. A hundred dollars is a handsome price, whereas a girl without a father and without personal attraction may fetch twenty or thirty dollars only. On the occasion called tililau, when the $s s d a q$ is agreed upon, the greater part of it is also

1 See supra, p. 39. 
handed over to the girl's father; but a sum of ten dollars is always allowed to remain unpaid, and the young man's father tries to be exempted from the payment of a still larger amount. This remaining portion is claimed if the husband divorces his wife without a good cause, or if he dies before her, but otherwise he leaves it unpaid or merely gives her a ewe. If a girl has no father the ssdaq is paid to the paternal uncle, or if she has none to a paternal cousin, or in default of such a relative to a maternal uncle, providing that he does not live far away. Otherwise she receives the $s s d a q$ herself, appointing a $l \tilde{u} k \bar{l} l$, or deputy, to act on her behalf and giving him some money in payment for his trouble.

Among the Ruâfa of the Ait Wäryâgäl the ssdaq is proportionate to the wealth of the bride's family and the number of her brothers and male cousins, who give strength to her husband, whereas her beauty is not considered in this connection. A low price for a virgin

- bride is thirty or forty dollars; a widow or divorced wife, on the other hand, only fetches from fifteen to thirty, even though she has many brothers, money, or property. Part of the ssdaq is often paid on the occasion when it is fixed, and it must be paid in full before the consummation of the marriage. Her father keeps one portion of it for himself and spends the rest in buying new clothes for his daughter and presenting her with an ornament called didli, which consists of dollar or half-dollar pieces threaded on a string of horsehair and is worn round the forehead. She puts it on 
on the morning after her first intercourse with her husband, and wears it then for a week, till her people go away; afterwards she adorns herself with it on special occasions only, such as religious feasts, weddings, and visits to shrines. The ssdaq must be returned if the woman is sent away because she is found not to be a virgin, or if she is divorced on account of notorious adultery.

The customs relating to the șdaq thus present many variations in different tribes and places. Not only is its amount sometimes fixed once for all and sometimes settled by the parties according to the circumstances, but it varies greatly in different communities and, when it is not fixed, within the same community as well. It is commonly smaller if the woman is a widow or divorced wife than if she is a virgin, but this is not the case everywhere. Sometimes it is paid in full before the consummation of the marriage, sometimes one-half of it or a smaller part is left unpaid. The "deferred" portion may be paid by instalments or compensated for by a present given to the wife by the husband; but in many cases it is only paid at the death of the latter or if he divorces his wife without sufficient reason, and in some tribes these are the only circumstances in which the sdaq or a part of it is paid at all, nothing of it being given when the marriage is contracted. As to the disposal of the sdaq we notice that in some places the girl's father spends the whole of the sum paid down on her trousseau, whereas in other cases he so spends only a part of it, keeping the rest for himself. In these 


\section{latter cases the sdaq is not merely, as Sidi Halil puts it, " similar" to a selling price. ${ }^{2}$}

1 SId Halil, op. cit. § $5^{1}$ (p. 54).

2 At Cairo, according to Lane (Arabian Society in the Middle Ages [London, I $88_{3}$ ], p. 23 ), a sum equivalent to about twenty pounds sterling is a common dowry among Arabs of the middle classes for a virgin, and half or a third or a quarter of that sum for a divorced woman or a widow. "Two thirds of the sum is usually paid before making the contract, and the remaining portion held in reserve to be paid to the woman in case of her divorce or in case of the husband's death. The father or guardian of a girl under age receives the former portion of her dowry; but it is considered as her property, and he generally expends it, with an additional sum from his own purse, in the purchase of necessary furniture, dress, etc., for her, which the husband can never take from her against her own wish" (see also Idem, Manners and Customs of the Modern Egyptians [London, 1896], p. 173 sqq.). Burckhardt (Arabic Proverbs [London, I8 30 ], p. I I 3 ) says that, at Cairo, "among the first-rate merchants the price is from 200 to 300 dollars; among those of the second class, from sixty to eighty; and the lower classes often pay no more than from three to five dollars. It is usual," he adds, "to pay half of the money immediately in advance." In Mecca the amount of the dowry, or mahr, varies extremely. "In vornehmen Familien wird ein beträchtlicher Mahr durch beiderseitigen Familienstolz erfordert und fügt der Vater des Brăutigams dem Versprochenen noch vieles hinzu. Mancher $\mathbf{V}$ ater aus den mittleren Klassen verlangt im Namen seiner Tochter einige hundert Dollars nicht wegen des Geldes, sondern weil er dadurch zeigen will, wie viel er auf sie hält. Andere heben hervor, ein guter Gatte sei ihnen willkommen, auch wenn er nur der Form wegen einige Zehner opfert. In den ärmeren Klassen muss man für die Jungfrau schon deshalb auf möglichst hohen Muhr dringen, weil daraus die sämmtlichen Kosten ihrer Aussteuer zu bestreiten sind und weil sie dadurch ein kleines Kapitälchen erhält für den Fall einer Scheidung. Die Ärmsten müssen über Alles hinwegsehen und mit ein paar Dollars vorlieb nehmen, wenn nicht ihre Schönheit die Begierde der Reichen erweckt" (Snouck Hurgronje, Mekka, ii. [Haag, 1889], p. 158 sq.). In Medina 400 dollars would be considered a fair average sum among respectable citizens (Burton, Personal Narrative of a Pilgrimage to Al-Madinah and Meccah, ii. [London, 1898], p. 23, n. 2). Among the Badawin of Al-Hijaz the "settlement" is usually about thirty Spanish dollars, half paid down, and the other owed by the bridegroom to the father, the brothers, or the kindred of his spouse; but some tribes will take animals in lieu of ready money (ibid. ii. III). Among the Bedouins of Mount Sinai the price of a girl varies according to circumstances, and is never exactly stipulated in a tribe. "It is from five to ten dollars, but sometimes amounts to thirty, if the girl is well connected and very handsome. Part only of the money is paid down, the rest standing over as a kind of debt. The father receives the money; or, if he is dead, the brother, or nearest male relation." The price of a widow is never more than half of what is given for a virgin and generally no more than one-third; and it is likewise paid into the hands of her masters (Burckhardt, Notes on the Bedouins and Wahábys [London, 1830], p. 152 sq.). The Aeneze, on the other hand, would consider it scandalous if a father should demand money for his daughter. Among the Ahl el Shemál he receives for her the homse, or "five articles," comprehending a carpet, a large silver nose-ring, a silver 
Yet, even though the woman has the full benefit of the sdaq, the marriage may nevertheless be an act of purchase. Among the At Ubáhti the price of 100 dollars and a female slave which the young man's father consents to pay, though it is afterwards reduced, is not the sssdaq, but the so-called tatmamt. Whilst the sșdaq is fixed once for all and consists of female wearing apparel, the tämamt is paid in cash and varies according to the circumstances, being chiefly determined by the wealth and position of the girl's father, as also by her own beauty. Whilst the ssdaq is only given on the day when the bride is brought to her new home, the tämamt must have been paid in full before the contract of marriage is made, the last portion of it being handed over at the timusit. And unlike the ssdaq the ta'mamt becomes the property of the girl's father, with the restriction that he is obliged to buy for his daughter a mat (ajertrtil) and a pillow (tágrart $\underline{\text { ) }}$ out of it ; in addition he perhaps spends some of the money on silver ornaments for her, but he is not required by custom to do so. If the girl's father is dead, the tatmamt is given to

neck-chain, silver bracelets, and a camel-bag of the Baghdad carpet manufacture; but they become her property (ibid. p. 62). In the rural districts of Palestine the marriage contract is avowedly an act of purchase, most part-or at least one-half (von Mülinen, 'Beiträge zur Kenntnis des Karmels,' in Zeitschrift des Deutschen Palästina-Vereins, xxx. [1907], p. 170)-of the dowry going to the girl's father (Van-Lennep, Bible Lands [London, 1875], p. 540; C. T. Wilson, Peasant Life in the Holy Land [London, 1906], p. 109 ; Klein, 'Mittheilungen uber Leben, Sitten und Gebräuche der Fellachen in Palästina,' in Zeitschrift des Deutschen PalästinaVereins, vi. [1883], p. 90; Jaussen, Coutumes des Arabes au pays de Moab [Paris, 1908], p. 49). It is this that makes the birth of a girl so much more welcome among the fellakin than among the townspeople, who do not appropriate the dowries given for their daughters (Wilson, op. cit. p. rog). Among the country-people and poor nomads of Judea the price of a wife often ranges from 150 to 250 dollars (Van-Lennep, op. cit. p. 541). 
her brother, mother, paternal uncle, or paternal cousin, and if she has no such relative she gets it herself. In case the marriage contract is reduced to writing, both the témamt and the sssdaq are mentioned in it.

The same institution is found among the At Buzéggu, At Yiznásen, and other tribes of the same neighbourhood, the Berbers of Algeria, ${ }^{1}$ and some of the Brâber. I was told that among the Ait Ndēr the tämamt is regularly double the amount of the ssdaq and may even be more, since the latter never exceeds thirty dollars. It is chiefly influenced by the beauty of the girl and her skill in weaving and spinning, but not by her virtue. It generally varies between forty and seventy dollars, and occasionally rises to a hundred ; but in exceptional cases even more may be paid for an extremely attractive and skilful girl, especially if she has many suitors. The témamt is paid with money only, or with animals, corn, or other provisions as well ; and here also it must be handed over to the girl's father before the wedding, whereas the ssdaq is paid later onone part of it, consisting of clothes, when the bride is fetched from her old home, and the other part at the death of the husband, or if he divorces his wife without a good cause, or, in the form of a voluntary present, for example a cow, at any other time he pleases. If the wife is divorced on account of her own misbehaviour, the tämamt must be returned.

The ticmamt is a Berberised form of the Arabic

1 Hanoteau and Letourneux, La Kabylie et les coutumes kabyles, ii. (Paris, 1873), p. 152 sqq. 
"ămâma, which means "turban," but this does not prevent it representing an old Berber institution which has survived under Islam, embellished with a new name. In Algeria it is also called tut $y$ it, which means "eating." 1 But a similar bride-price is found in many Arabicspeaking tribes in Morocco as well, where it is called mákla, or "food," and the tämamt and mákla have been represented to me by the people themselves as identical institutions. In the Hlot and Tliq the mákla is always paid in money, and is much higher than the sdaq, varying between twenty and two hundred dollars. ${ }^{2}$ In the Hiáina, on the other hand, it was said to consist of a bullock, a few sheep, wheat, and salt butter, which the parents of the young man take with them when they, in the company of the $f q \tau$ of the village and a few friends, go to pay the sdaq; but here also the girl's father keeps the mákla for himself.

Another survival of the old Berber marriage by purchase is perhaps, at least in part, the hdîya, "present," which in Andjra is given to the girl's father. As we have seen, ${ }^{3}$ it is discussed before the parties come to an agreement, but, unlike the șdaq, it is not mentioned in the written contract. Three days before the bride is fetched from her old home, men and boys from the young man's village take there the portion of the hdîya which is called l-hditya den-nga del-qauts, consisting of a considerable quantity of corn out of

1 Hanoteau and Letourneux, op. cit. ii. 152.

2 Michaux-Bellaire and Salmon, 'Les Tribus arabes de la vallée du Lekkoûs,' in Archives marocaines, vi. (1906), p. 226.

3 supra, p. 30 sq. 
that which was cleaned on the nhar n-nqa del-arûs, together with the butter, oil, candles, sugar, salt, henna, and slippers agreed upon. Two days later, on the day nhar d-djwâri del-arûșa, a large party of relatives and friends of the young man, accompanied by musicians, take to the girl's place the promised bullock, l-hdîya det-tsaur. People from her village meet them on the way, and when they approach her house some bachelors of the young man's party lift the bullock on their backs and carry it thus to the yard, where it is slaughtered and cut up, while the men are firing off their guns, and the girl-friends of the bride are making a quivering noise. One-half of the meat is left there for the entertainment of the women, the other half is taken to the young man's father, and the skin becomes the property of the bride's brother. In the case of a poor man's wedding, a sheep or goat is sent instead of a bullock.

At Tangier the bridegroom or his father sends, on the morning of the third day before the bride is brought to his home, some male friends and musicians to her house with a bullock or calf, which is slaughtered there at the door. When this is done they make fâtsha and go away, the musicians taking with them the head and skin of the animal. This day is called nhar $d$-dbêha, "the day of the sacrifice."

Among the Ait Wäryâgäl, on the day before the wedding is celebrated in the bridegroom's house, his uncle or brother is sent to the bride's father with three or four goats. But about a week previously his father 
has already taken to the latter a large quantity of wheat and barley-some thirty to sixty mudd_-and a mudd of beans, which he uses for the entertainment of the unmarried girls of the village who now spend all their time with his daughter, keeping for himself anything that remains. The amount of corn and beans was agreed upon at the same time as the ss $\underline{d} a q$, which consists of money only.

Besides payments or gifts to the girl's father a payment is also, in many tribes, made to other members of her family. The At Ubáhți call this payment lihra, which is a Berberised form of the Arabic kra, meaning " hire" "or "wages." It consists among them of ten dollars paid to the girl's mother, the same amount paid to her eldest brother, and smaller sums or presents given to her younger brothers, sisters, and other near relatives. It is paid on the same occasion as the támamt, but previously to it ; although, if the father of the young man cannot then pay it in full, some article of value, as a gun or pistol, may be left as security. Like the ssdaq, but unlike the tatmamt, it is never returned in the case of divorce.

Among the Arabs of the Hiáina, if the girl's father shows himself unwilling to accept the proposal, a réswa, "bribe," is offered to other male relatives of hers in order that they shall try to induce the father to give in. But even if the latter makes no objections to the match, réswa is paid to them, though in this case only on the occasion when the bride is fetched. 
Among the Ait Sádden, at the ceremony of lfâth when the first part of the sssdaq is handed over to the girl's father, her eldest grown-up brother, if she has any, also claims a sum for himself, which is fixed now but only paid afterwards, at the ceremony of asgiurt the brother does not allow the quivering noise to be made on the latter occasion unless he has previously received the sum agreed upon. This money, which is called rršut -from the Arabic réswa-may perhaps amount to some six or eight dollars. It is only given to the eldest brother of the girl, even though she have several brothers who are older than herself.

In the tribe of the Ait Warain, before the sssdaq is paid to the girl's father, the other members of her family receive from the young man's father some money or a garment, by which he hopes to induce them to help him in settling the ssdaq. Should a brother or uncle of the girl be left without such a present, it may happen that he, on the occasion when she is going to be taken away from her home by the bridegroom's party, will step forward and claim the money which has not been given him. If it is refused a fight ensues between the men of the bride's village and those of the bridegroom's party, first with stones and afterwards, if the refusal is persisted in, with guns. This is a fight in good earnest, and should anybody be killed there would be blood-revenge; it has happened that the bride herself has been wounded by stones. If the men of the bride's village win, the bridegroom's people have to pay the demanded sum, whereas in the opposite 
case the latter carry away with them the bride by force.

Among the Shlöh of Aglu, when the bridegroom's party come to fetch the bride, her brother locks the door of the house, and does not open it until they have paid him a small sum of money.

In Andjra, again, when the bride has been lifted into the box on the back of the mule which is going to carry her to her new home, her brother seizes hold of the animal and tells the bridegroom's people that he does not allow them to take away his sister unless they pay him a sum of money; and it is only after the bridegroom's brother, or the person who has led the mule, has paid him, say, three or four dollars as hláwa, "douceur," that the procession is allowed to start. It is also the custom in Andjra that if the eldest brother of the girl is opposed to her marriage, though her parents be in favour of it, the young man tries to prevail upon him by offering him a hláwa, as he has a kind of veto in the matter. Eight or ten dollars are perhaps sufficient for the purpose; but if the girl has many suitors the hlarwa may even amount to fifty. There is a similar custom among the Ait Wäryâgäl, who call the money in question ddaztttat, the Arabic $z t a t a$, which denotes the present or fee given to a $z \dot{e} t t a t$, that is, a person who conducts a stranger safely through his tribe.

The presents spoken of are thus expressions of a feeling of family solidarity. They show that the father or parents of the girl are not the only ones who have 
something to say in the matter of her disposal, and that the eldest brother in particular, who in case her father is dead is her recognised guardian, is an influential person even during his lifetime.

Presents, consisting of clothes, ornaments, and other things, are also given to the girl. These may, as we have seen, ${ }^{1}$ at least in part, be included in the sdaq, but in many Arab tribes they form a consideration by itself, called $d h \bar{a} z{ }^{2}$ which is discussed before the marriage contract is made. ${ }^{3}$ Among the Ulâd $\mathrm{Bu}$ 'Ăzîz, who require no part of the șdaq to be paid in advance, the $d h \bar{d} z$ comprises a great variety of things, not all of which, however, are meant for the fiancéesuch as a bullock, a sheep or two, a camel-load of wheat, a large jar (gúlla) of salt butter, four $̌ q o q$ of cotton-stuff, a belt (hặậm) and a veil (kěnbüs) of silk, a silk kerchief (sěbnîya), a black headgear called కarbîya, another headgear called ̌anbür, several pairs of slippers (one for the fiancée and the others for her

1 Supra, p. 69 sq.

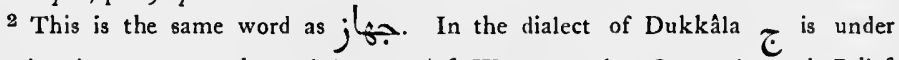
certain circumstances changed into $\supset(c f$. Westermarck, Ceremonies and Beliefs connected with Agriculture, certain Dates of the Solar $Y_{e a r}$, and the Weather in Morocco [Öfversigt af Finska Vetenskapssocietetens Forhandlingar, Bd. liv. 1911-1912, Afd. B. $\mathrm{N}: 0 \mathrm{I}]$, p. 57).

3 See Michaux-Bellaire and Salmon, loc. cit.p. 225 sq. In Palestine, also, the word denotes the stipulated presents which the bridegroom gives to the bride (Klein, loc. cit. p. 9I), whereas in Egypt, according to Lane (Modern Egyptians, p. 175), it means the articles which are bought with the dowry paid by the bridegroom and the additional money supplied by the bride's family, and which become the property of the bride. M. E. Mercier (La Condition de la femme musulmane dans l'Afrique septentrionale [Alger, 1895], p. 5I) observes:- "Il arrive que le djehaz (somme devant être affectée à l'achat de bijoux ou objets du trousseau de l'épouse, au moment de la consommation du mariage) se confond, en tout ou en partie, avec le neked; il n'est pas donc absolument obligatoire; cependant, dans la pratique, il est souvent stipulé à part." 
parents and brothers), a looking-glass, a comb (mäststa), soap for washing, henna, walnut root or bark (swak), ochre ('ăkdr), gum-benjamin ( $j d w i)$, dates, and other articles, especially such as are to be worn. If the young man is of a well-to-do family the $d h \bar{a} z$ may also include two silver bracelets ( $d b \bar{a} l j)$, two silver earrings (dwaiwạh), a silver breast ornament with a chain called kŭtfîyăt, and a female slave. Some ten days or more before the wedding the $d h \bar{a} z$ is taken to the tent of the girl's family by men and women of the young man's village, who are entertained there with a meal of séksu, after which the camels are unloaded and the presents exhibited to the admiring villagers. The girl's father gives a few of the dates and a little henna to everybody who happens to be there; but the girl herself is all the time sitting in another tent, being too bashful to appear. Among the Ait Támelldu the young man on the day of the proposal sends to the girl the so-called nnóqra, "silver," consisting of a silver ornament, dates, and henna.

In many cases the girl's father, also, gives her something in addition to what is bought with the sdaq. At Fez I was told that custom requires him thus to spend on her trousseau at least the same amount from his own money-the so-called mitsal. ${ }^{1}$ In Andjra he

1 In his description of the marriage customs of $\mathrm{Fez}$ four hundred years ago Leo Africanus (The History and Description of Africa, ii. [London, 1896], p. 450) writes with reference to the dowries bestowed by fathers on their daughters that "some doe striue so much to excell others, that oftentimes many gentlemen haue brought themselues vnto pouertie thereby." In Egypt not only the dowry paid by the bridegroom but an additional sum supplied by the bride's family, which is often more than the dowry itself, is expended in purchasing the articles of furniture, dress, 
is expected at his own expense to provide her with a ywar of wearing apparel $;^{1}$ and among the Ait Támèldu it is a matter of pride to a father to give his daughter a good ligqâma, consisting for example of a cow, some sheep, silver ornaments, silk kerchiefs, blankets, a belt (túggas), and other articles, worth perhaps from fifty to two hundred dollars; though a poor man may have nothing to give but some clothes bought with the amerwas. Among the Shlöh a daughter's marriage is not looked upon in the same business-like manner as among other Berbers.

and ornaments for the bride (Lane, Modern Egyptians, p. 175). In Upper Egypt, as at Fez, "the bride's tather is expected to give a like sum with that paid by the groom, - the entire amount being the bride's portion, which is ordinarily invested in coins or jewelry to be worn by the bride as her exclusive personal property" (Trumbull, Studies in Oriental Social Life [Philadelphia, 1894], p. 20). So also at Aleppo in Syria "le prix payé est ... employé, a vec une pareille somme que donne le père de la future, en meubles, ustensiles, effets d'habillement" (Guys, $U_{n}$ Dervich algérien en Syrie [Paris, 1854], p. 199). Among the Muhammedans of India "the bride's father is bound to furnish her with a wedding outfit, unless he is in straitened circumstances, when the obligation rests with the husband. When a man advances a sum of money towards the trousseau of his future wife, it is obligatory on the father, if he be possessed of means, to do the same or contribute such an amount as is customary" (Ameer Ali, op. cit. ii. 508).

I M. Michaux-Bellaire ('Quelques tribus de montagnes de la région du Habt,' in Archives marocaines, xvii. [1911], p. 128) says that among certain mountain tribes in Northern Morocco the father spends the sdaq on his daughter's šwar, and generally, in addition, uses some money of his own for the same purpose; but in Andjra the word šwar is applied only to articles which he buys with his own money, not to those bought with the șdaq. 


\section{CHAPTER III}

\section{CEREMONIES IN THE BRIDEGROOM'S HOME PREVIOUS TO THE FETCHING OF THE BRIDE}

Muhammedan law appoints no specific ceremony for the celebration of a marriage ; but, to quote Sĩdi Halil, " it is commendable to give a wedding feast, a day after the home-bringing of the bride, and it is incumbent on every guest specifically invited to accept, even though he be fasting." 1 In Morocco custom requires, at least if the parties have not been married before, that a wedding feast should be held in the bridegroom's home, and this is generally a big affair. An old Moorish proverb says that the Christians spend their money on lawsuits, the Jews on religious festivals, and the Moors on weddings. ${ }^{2}$

A wedding is called in Arabic "örs or "ärs, and in Berber támg்ra (Shlöh), támğra (Brâber of the Ait Yúsi

1 Sidi Halil, Muhtasar, $\$ 289$ (Russell and Abdullah al-Ma'mun Suhrawardy, 'A Manual of the Law of Marriage' from the Mukhtasar of Sidi Khalil [London, s.a.], p. 102). Respecting marriage feasts, the Prophet is reported to have said :"The first day's feast is an incumbent duty; and the second day's, a sunneh ordinance; and the third day's, for ostentation and notoriety (Lane, Arabian Society in the Middle Ages [London, 1883], p. 232 sq.). Cf. El-Buhāri, Sah̆th, Ixvii. 67 sqq., French translation by Houdas and Marçais, vol. iii. (Paris, 1908), p. 578 sq9.

2 Diego de Torres, Relacion del origen y sucesso de los Xarifes (Sevilla, 1586), p. 26 r. 
and Ait Ndēr), țimăgra (Ait Sádděn), ddimăgra (Ait Wäryâgaal), úrär (Aț Ubáḩti and neighbouring tribes), or islan (Ait Waráin). A bridegroom is called in Arabic 'ărûs, ărûs (Northern Morocco), or 'ărîs (Fez, Dukkâla, etc.), and in Berber isli (Aglu, Ait Yúsi, Ait Sádděn), ásli (Iglíwa, Ait Táměldu, Aț Ubáhți), or ạ́sri (Ait Wäryâgăl); a bride, in Arabic 'ărûsa, 'ărûșa, or 'ărûṣ (Hiáina), and in Berber tislit (Aglu), tíslit (Ait Yúsi, Ait Sádděn), táslit (Iglíwa, Ait Táměldu), țáslit (Aț Ubáhți), or dadsriț (Aiț Wäryâgäl).

Marriages are commonly celebrated in the autumn, when the harvest has come to an end and the granaries are full of corn. ${ }^{1}$ The Ait Waráin, for example, never hold a wedding at any other time of the year; whereas among the At Ubáhti weddings also, though less frequently, take place in the spring, and among the Ait Támeldu in other seasons as well, whenever it suits the parents of the fiancé. Marriages are avoided in Moharram, the first month of the Muhammedan year, at least by shereefs ${ }^{2}$ and according to Māliki law no valid marriage can be contracted by a person while on pilgrimage. $^{3}$ At Tangier Thursday is considered to be

1 Among the peasantry of many European countries marriages are likewise celebrated by preference in the autumn or the beginning of the winter; "man heirathet, wenn die Ernte geborgen ist,-das ist die hier allgemein vorwaltende Anschauungsweise" (v. Schroeder, Die Hochzeitsbräuche der Esten und einiger andrer finnischugrischer Volkerschaften, in Vergleichung mit denen der indo-germanischen Volker [Berlin, 1888], p. 48 sq.). Cf. van Gennep, Les Rites de passage (Paris, 1909), p. 199.

2 The Egyptians consider it unlucky to make a marriage contract in Moharram (Lane, Manners and Customs of the Modern Egyptians [London, 1896], p. 432).

3 Sidr Halrl, op. cit. $\$ 49$ (p. I6) :- " The marriage will be invalid, if any one of these three [viz. the bridegroom, the bride, and the wali] be in [the condition of] ihrām." Cf. ibid. \$66 (p. 23); Ameer Ali, Mahommedan Law, ii. (Calcutta, 1908), p. 324 ; El-Buhărr, op. cit. lxvii. 31, vol. iii. p. 56 r. 
the most suitable day for the fetching of the bride, in Andjra and among the Ait Táměldu either Sunday or Thursday, and among the Ait Wäryâgäl and Ait Sádden Thursday or Monday. ${ }^{1}$ The eve of Friday, the Sabbath of the Muhammedans, is regarded by them as a blessed night; and Sunday is considered a suitable time for the beginning of married life as being the first day of the week. ${ }^{2}$ It is also held to be the most favourable day for the beginning of the autumn ploughing, though in some tribes Thursday and Monday are likewise regarded as suitable for this purpose. ${ }^{3}$ Among the Tsul, again, the bride may be brought to her new home on any day but Tuesday, and among the Ait Waráin on any day but Friday. ${ }^{4}$ The Ulâd Bu-'Ăzîz

I In Cairo, according to Lane (Modern Egyptians, p. 175 sq.), "the bridegroom should receive his bride on the eve of Friday or that of Monday; but the former is generally esteemed the more fortunate period." According to Burckhardt (Arabic Proverbs [London, 1830], p. 114), on the other hand, Monday and Thursday are the days on which the ceremonies immediately previous to the marriage-night are performed; but Lane (op. cit. p. 574) denies the accuracy of this statement so far as Monday is concerned. In Tripoli, as in Morocco and Egypt, Thursday night is a favourite night for weddings (Mrs. Todd, Tripoli the Mysterious [London, 1912], p. 94). Among the Turks "Donnerstag ist der allgemeine Heirathstag. Infolge der Empfängniss des Propheten Mohammed, wird die Nacht, die von Donnerstag auf Freitag folgt, als die günstigste betrachtet; sie muss daher auch die erste Hochzeitsnacht sein. Witwen und Geschiedene heirathen am Montag" (Löbel, Hochzeitsbräuche in der Türkei [Amsterdam, 1897], p. 25 n. 1). Among European peoples Tuesdays and Thursdays are frequently considered the most suitable days for weddings (v. Schroeder, op. cit. p. 51 sq.; Sartori, Sitte und Brauch, i. [Leipzig, 1910], p. 60).

2 Cf. Trumbull, Studies in Oriental Social Life (London, 1895), p. 49:- "Sunday is a favorite day with Muhammadans for the beginning of an enterprise."

3 See Westermarck, Ceremonies and Beliefs connected with Agriculture, certain Dates of the Solar Year, and the Weather in Morocco (Öfversigt af Finska Vetenskapssocietetens Förhandlingar, Bd. liv. 1911-1912, Afd. B. N:0 1), p. 8.

${ }^{4}$ Addison (West Barbary [Oxford, 1671], p. 183) says that a bride must not be taken to her new home on a Tuesday, Wednesday, or Friday. In ancient Rome marriages of virgins were not celebrated on "high holidays" (Plutarch, Quaestiones Romanae, 105). 
celebrate their weddings at full moon in order to be safe from robbers.

The wedding proper is preceded by certain ceremonies in the homes of both bridegroom and bride. We have first to notice those connected with the cleaning of the wheat which is to be used for the wedding.

In a village in the Garbîya where I was staying the women of the various households came in groups to the place where the fiance was living, each group carrying a flag and every woman taking with her some loaves of bread, salt butter, eggs, and one or two small coins, as presents to the young man's mother. They sat down in a tent pitched for this occasion, on the top of which four flags were flying, and began to clean the wheat before them. The children of the village were standing outside the tent, while the men and bigger boys were gathered under a large shady tree out of sight. When the wheat had been cleaned and put in baskets, some guns were fired off and a meal was served out of the presents brought by the women and other provisions supplied by the father of the fiancé. All the villagers partook of this meal, first the men and boys together and afterwards the women. The wheat was subsequently taken to a mill to be ground. The occasion in question is in the Garbîya called tákhrij, [the] "taking out" [of the corn from the place where it is kept], or täsyer, "sifting." In the neighbouring mountain tribe Jbel lä-Hbib it is named tsasyar.

In Andjra the day when the corn is cleaned in the 
young man's house is called nhar n-nqa del-ärûs, " the bridegroom's day of cleaning." Four flags on the roof of his house indicate the importance of the occasion. In the yard there is lying a great quantity of wheat, barley, and durra. In one of the heaps is thrust a dagger, and on the top of it is placed a bowl containing a raw egg and some salt. The object of the dagger and salt is to keep away evil spirits from the corn, whilst the egg is put there "that the wedding shall be without rain and the life of the bridegroom shall be white"-the whiteness of the egg representing fine weather and a bright life. The unmarried women of the village sit down round the heaps to perform the principal business of the day, the cleaning of the corn ; but before they commence, the father of the fiancé sprinkles some salt both on them and the heaps as a safeguard against the spirits. The girls are singing while doing the work; the married women, standing behind them, make their usual quivering noise; and the bachelors repeatedly fire off their guns, which is also supposed to frighten away the evil spirits. When the cleaning of the wheat is finished the women and bachelors are, separately, entertained with kúsksu and meat, after which they all go away. The flags are left on the house till the day when the bridegroom has the henna washed off his hands. The rubbish which has been removed from the corn is put by his mother in some clean place, as it must not be defiled. The egg in the bowl is buried by her under the threshold of the house that it shall be stepped over by the young couple, 
whose lives are thereby supposed to become happy; and the salt is taken by the young man and placed in the roof over the bed where he will sleep with his wife.

Among the Tsal, another Arabic-speaking mountain tribe, belonging to the southern Jbâla, the wedding is preceded by a similar occasion, called $n$-năqa, when the wheat is cleaned in the house of the fiance's father, at the top of which has been fastened a bamboo cane with a white flag, to remain there till the wedding is over. All the women of the village, married and unmarried, assemble at the house, and are entertained with bread and figs before they commence their work. While some of them are cleaning the wheat the others dance and sing, clapping their hands; and when they get tired the latter take to the work and the former begin to dance. The following song is sung both by those who are amusing themselves and those who are

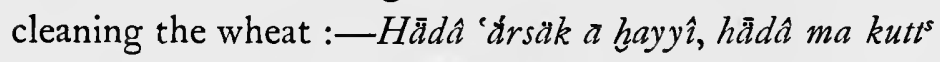
t’äntsmẹnna; farhô lak bnāts ammák, ḍafrô ráshum bă lhanná, "This is your wedding $\mathrm{O}$ my brother, this is what I wished for ; the daughters of your father's brother rejoiced for your sake, they plaited the hair of their head with henna." When the women clean the wheat they put the grit in a bowl with a raw egg in it; and on the evening when the bridegroom is painted with henna the first time, his sister takes this vessel and throws its contents into a spring in order that there shall be much rain for the good of the crops and that the newly married man shall be liked by the community. After the wheat has been cleaned, it is distributed 
among the various households of the village to be ground the same night. In the morning the women come back to the house each with a sieve ( $\dot{g} \dot{a} r b \bar{a} l$ ) to sift the flour. This occasion is therefore called $\iota^{s} \dot{g}$ '́rbil, " sifting."

Among the Arabs of the Hiáina there is likewise a white flag on the roof of the house where the wheat is going to be cleaned; and when the days of the wedding have come to an end, it is blown to pieces with guns, so that the bas, or evil, shall go away. The women of the village clean the wheat in the daytime and, after supper, grind it with the handmills which they brought with them. During the grinding, which in the case of a big wedding takes two nights, the men also come to the place to amuse themselves with playing and singing together with the women. The wheat must not be taken to other houses to be ground; this is done at a funeral and would consequently be bad at a wedding. This feast, which is called $t$-then, "the flour," is the next day followed by the $t^{s} \dot{g}$ arbizl, when the women all the day long are busied with sifting the flour and are entertained

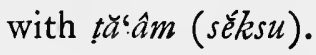

Among the Ait Sádden the wheat is cleaned in the yard of the fiance's father by all the women of the village. The grit is collected in a sieve (tallunt) containing a silver bracelet (adeblij) and the bridle (al$\left.g^{y} \hat{a} m u \dot{u}\right)$ which will be put on the mare ridden by the bride when she is taken to her new home. This grit is afterwards thrown by the young man's mother into a spring or river or buried in the ground, so that nobody 
shall work magic with it. The men of the village are also present on this occasion, and there is much powderplay, singing, music, and dancing. The women are entertained with bread and butter and perhaps tea, or with $t t a c a m$ and milk, but no meat ; and a meal is likewise given to the bachelors. This day is called ass ufran, "the day of the cleaning of the corn." The work may have to be continued on the following day, but without any feasting connected with it. The cleaned wheat is then sent to be ground at Fez or Șefru or a place on the river Sba where there is a water-mill, unless the quantity is very small, in which case the women of the village grind it with their handmills at the place where it was cleaned. The day when the flour is brought back from the mill is called ass n-yizuid, "the day of the flour"; and it is then received on the road by the men and women of the village with singing, music, and powder-play. On the same occasion the clothes and ornaments of the bride are also, in many cases, brought from the town.

Among the Ait Nder the wheat which has been cleaned by the women of the village in the tent of the fiance's father is at night ground in the same place with a few handmills, each of which is turned by two women, married or unmarried. Men are also present ; and it is considered a good omen that the bachelors take part in the grinding, replacing one of the women at the mill when she gets tired. While the grinding is going on the women are singing, and the unmarried men who take part in the work sing with them, while 
other men are firing off their guns outside the tent. Both at the cleaning and the grinding of the wheat the people are entertained with food. After the grinding, which, if the young man's father is a man of means, may have lasted for several nights, a long bamboo cane with a white kerchief tied to it is thrust through the tent or fastened to one of the tent-poles as an indication of the coming wedding. This is done in the morning, and, when the flag is seen, visitors in large numbers come to the tent, where they are treated with bread and salt butter. This occasion is called bạtțî. The next day some men and women, by invitation of the young man's father, go to the thicket with their animals to bring home fuel; and when they come back they are rewarded with a meal of bread and salt butter.

Among the At Ubáhtí, in conformity with the custom of most other tribes, a cane with a white flag is put on the top of the tent of the fiance's father on the morning of the day when the cleaning of the wheat begins, and is left there over the whole wedding. The men of the village also come to the place and fire off their guns inside and outside the tent. The grit is afterwards thrown by the young man's mother or sister into a river, water-course, or spring, partly in order to prevent anybody doing harm to the bridegroom or bride by practising magic with it, but partly also to make the season rainy and the crops good. After the wheat has been cleaned it is washed, dried, and ground in the handmills brought to the tent. If the fiance's father is fairly well-off, the grinding lasts for several days 
and nights, during which the women are not only busy with the work, but also amuse themselves with singing, playing, and dancing, and the men discharge gunpowder inside and outside the tent, sometimes also taking part in the grinding and singing, which is supposed to bring good luck. When the grinding is finished some men of the young man's family go to the thicket to gather fuel. All this time the fiancé himself is not to be seen, but spends his days and nights in another tent with his áuzir, or best-man.

Among the Shlöh of Glawi, some time before the wedding, there is the so-called igwis, or cleaning of wheat or barley in the house of the fiance's father. When the women of the village come to do the work they bring with them small presents of food. A meal is given them both before and after the work, and the latter meal is followed by dancing. The Ait Táměldu call this occasion áfran. Among the Ruâfa of the Ait Wäryâgäl, on the other hand, there is no such ceremony, but the young man's father during the week preceding the wedding goes about with a mule to all the houses in his own village, as also to those of friends living in other villages, distributing wheat to be ground by the women.

As appears from some of these statements, a superstitious importance is frequently attached to the grit which has been removed from the wheat. Care is taken that it should not fall into the hands of anybody who might practise sorcery with it, or it is thrown into water to produce rain for the benefit of the crops. 
Among the Ait Yúsi, again, it is thrown on the floor of the bridegroom's tent or house in order that the wedding shall be attended by many guests - as many as are the pieces of grit; and at Amzmüz, when the bride is carried into the bridegroom's house, the latter, who is sitting on the roof, throws on her not only dried fruit but also grit removed from the wheat on the day when it was cleaned.

The most important ceremony which takes place in the fiance's home before the fetching of the bride is the painting of him with henna, a colouring matter produced from the leaves of the Lawsonia inermis, or Egyptian privet. I shall give some detailed accounts of this custom, the particulars of which vary somewhat in different tribes and places.

In Andjra, the night before the day when the bride is fetched from her old home, a feast called l-lîlêts del"ărûs, "the bridegroom's night," is celebrated in his father's house. Musicians, tabbâla and gaiyâda, playing on drums and oboes, come and give an evening serenade to the bridegroom (keimissü 'ălă l-ărîss), who is inside the house with his family. The other people of the village are assembled in the yard, and the banging of guns is mixed with the sounds of music. When this performance, called $t^{s}$ emsiya, "the wish of a good evening," has been going on for about half an hour, the bridegroom comes out of the house and welcomes the musicians and other people in the yard, who answer him with a Nbârạ̣k mösê̋̂́ $\underline{d}$, "Be blessed and lucky." 
$\mathrm{He}$ invites the musicians to enter the house, or, if it has only one room, a neighbouring house of which he disposes for this occasion. They are there entertained with tea and küsksu served with mutton or goat's flesh, and the same is offered to the bridegroom's relatives who are sitting inside, whereas the people in the yard have only kúsksu with meat set before them.

After the meal the bachelors ask the musicians to go with them to an open place in the village, which is soon crowded with men and boys attracted there by the music and powder-play. From there they all go to meet the guests from other villages, who are now approaching in a body with dancing-boys and dancing-girls, the latter being the only women among them; and the whole party then proceed to the bridegroom's house, where they are received by him with a greeting of welcome, which they answer with the words, Nbârặk mös ôûd ma mậYi t'a"mel, "May it be blessed and lucky what you are going to do." The musicians retire to the room they occupied before and are there again entertained with a meal, this time without küsksu; and food is likewise given to the people in the yard. This meal is followed by several hours of music, singing, and dancing performed by the prostitutes from other villages.

Towards daybreak the bachelors call out the bridegroom, cover him up with a hâyẹk, ${ }^{1}$ and walk with him

I The hâyẹk is a long, rectangular, and seamless piece of white woollen cloth, worn without fastenings by men and women; it is also called ksä, especially when made of finer material. See infra, p. $166 \mathrm{n}$.; Dozy, Dictionnaire détaillé des noms des vêtements chez les Arabes (Amsterdam, 1845), p. 147 sqq.; Meakin, The Moors (London, 1902), p. 5 I sqq.; Doutté, Merrâkech (Paris, 1905), p. 248 sqq. 
and the musicians to the open place in the village. From there they slowly march back to the yard, the bridegroom surrounded by the bachelors, who are carrying four flags, and behind them come the musicians playing their instruments. The bridegroom is now and as long as the wedding lasts regarded as a sultan and the bachelors as his ministers (wazâra or wúzra). The latter are singing :

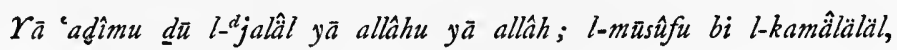
yă ăzî̀zu ya răbbî,

O great Majesty O God, O God; the one who is girded with a sword ${ }^{1}$ good luck to him for ever, $O$ dear one, $O$ God.

On their arrival in the yard the bridegroom sits down with his face still covered and the wazâra seat themselves round him, while the women present are standing. His mother comes out from the house, carrying in one hand a bowl containing henna, an egg, and four candles, and in the other a bottle filled with water. She places the bowl and the bottle on the ground, and addresses her son with the words :- Alláh yerd 'álik, " May God be gracious to you." The bridegroom's best-man, who is called sometimes l-hâjeb deș-șúltan, " the Sultan's chamberlain," sometimes l-uzîr, "the vizier," takes the bowl, lights the candles, and gives them to the bachelors who are holding the flags and kneeling before the Sultan. He breaks the egg, mixes it with the henna, and asks the bachelor next to him to pour some water over it. While slowly stirring this mixture with the little finger of his

1 This epithet is given to the bridegroom although he wears no sword in Andjra. In the neighbouring tribe of the Fahṣ he wears one. 
CHAP.

right hand, he sings as follows, the other wazâra chorusing his words :

Bismillậh r-rahmân r-rahîm yā allâh

'I $\underline{d}$ bi llâh mẹn š-seitân r-rajìm yã allâh

Qáddemna sîyidna Bâlâl u yā allâh

Qáddemna sîyidna 'Utsman u yā allâh

Qáddemna sî̀idna ${ }^{\circ} \hat{E}$ sa u yā allâh

Qáddemna sîyidna "Alî u yā allâh

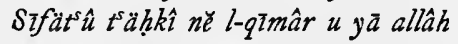

Medd yiddék nhännî̀ lek āyâ mülüi

Medd yiddék mnẹ kmâmäk ayyâ mülái

L-yūm wågfét iyämăk āyâ mũläi,

In the name of God the merciful and compassionate, $O$ God I take refuge with God from the devil, the stoned one, O God We have made our lord Būläl our leader and O God We have made our lord ' $U t^{5}$ man our leader and $\mathrm{O}$ God We have made our lord 'Êsa (Jesus) our leader and O God We have made our lord "Alr our leader and O God His face is like the moon and O God

Stretch out your hand we shall paint you with henna, O my lord Stretch out your hand from your sleeve, $\mathrm{O}$ my lord To-day your luck has stood up, O my lord.

The vizier applies henna to the palm of the bridegroom's right hand and then to the left palm, after which his little fingers are dipped into the bowl; and the vizier further smears some henna on his own hands.

After this ceremony is accomplished and the women have retired, the vizier orders the musicians to play, takes the four burning candles and puts them in the bowl containing the rest of the henna-mixture, lifts the bowl on his head, and begins to dance before the Sultan. After a while he hands the bowl with its contents to another bachelor, who does the same; and thus all the wazâra dance in turn with the bowl on their heads till 
the last one lets it drop down on the ground and break. This is supposed to remove l-bas, that is, "the evil." The Sultan now retires to his room and the people are entertained with kứsksu and meat. The bridegroom has his meal in the company of his family so as not to be seen eating by anybody else, and it is the custom that he should restrict himself to a very small quantity of food; indeed, throughout the wedding he must neither eat nor drink in public, but, if he needs it, a little food or. water is given to him secretly by the vizier when it is dark. After the meal the guests go away, and the musicians have a rest.

Among the Jbâla of the Tsal the painting of the bridegroom with henna is connected with ceremonies which differ in various points from those which we have just described. The first time it takes place in the evening of the day when the flour is sifted in his father's house. Dressed in a white cloak (sélh $\bar{d} m),{ }_{1}^{1}$ with a sword hanging over his right shoulder, the bridegroom comes walking to the house, accompanied by the bachelors and young married men of the village. The procession is headed by a young girl, the daughter of his father's brother, who is waving a silk kerchief towards the bridegroom, though they are separated by two men who, immediately in front of the latter, are crossing their swords to drive away evil spirits; there is no other

1 The sélhäm is a hooded cloak made of one piece of cloth, without sleeves, and open down the front ; it requires no fastenings, the front of it being caught together for a couple of inches to keep the hood on the head (cf. Meakin, op. cit. p. 59; Idem, An Introduction to the Arabic of Morocco [London, I891], p. $5 \mathrm{I}$ ). The selhäm is a more aristocratic garment than the jẹllạb, on which see infra, p. $114 \mathrm{n}$. 
CHAP.

woman in the procession besides her. The men are singing :

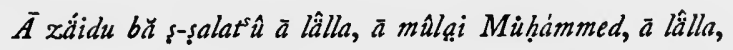

Oh go on with the prayer, O lady, O my lord Muhammed, $O$ lady.

When they are approaching the house they sing :

$\bar{A}$ bâba háayyi, à injjik alláh; à qtib r-rêhan, ả injjik alláh,

O father, my brother, oh may God save you; O switch of myrtle, oh may God save you.

On the arrival of the procession in the yard, the bridegroom sits down on a mézwud, or skin-sack, filled with clothes, and has his hands painted on both sides with henna by a daughter of his father's brother. Behind the bridegroom stands another girl-cousin of his, or some other girl from his village, holding in her hand the point of his hood with a silver bangle slipped over it. The assembled people, one by one, put money on a palmetto tray covered with a kerchief, on which has been placed another silver bangle for the purpose of making the contributions plentiful, while a berrah, or crier, calls out the name of every donor and the amount given by him. This collection is afterwards taken by the bridegroom's father; but some other money, intended for the bridegroom himself, is pushed into his mouth, where he leaves it till the ceremony is over. While he is being painted with henna all the women sing :-

$$
M^{w} \text { add yiddék, nhännihâ yā kayyî̀, }
$$

Extend your hand, I shall paint it with henna $\mathrm{O}$ my brother. 
When this ceremony has come to an end and the bridegroom is gone, the girl who painted him with henna puts the bowl on her head and dances with it singing :

Ma tștah̆ bè z-zlîfa $\dot{g} \bar{a} r$ lli hîya drî́fa,

May only she who is beautiful dance with the small bowl.

The other women also join in the song. At last she takes the bowl from her head and throws it on the ground so that it breaks, and thereby, it is thought, rids the bridegroom of his bas. But previous to this, the raw egg which was put into the bowl together with the henna is removed from it to be used in the same manner at the second painting of the bridegroom, after which it is boiled with the liver of the sheep slaughtered on the latter occasion. They are eaten together by the bride and bridegroom for supper the second night they pass together, the liver for the purpose of making them dear to one another, and the egg that their future shall be bright.

The occasion just described is called l-h̆anna s-sgêra " the little henna," and is followed the next evening by l-hánna l-kbira, "the great henna," when the bridegroom is painted for the second time, with ceremonies similar to those of the night before. But the latter feast is on a much larger scale. While "the little henna" was only attended by relatives of the bridegroom and folk from his own village, "the great henna" attracts people from near and afar, who bring with them séksu and meat as a present to the bridegroom's father. The former evening no such gifts 
were offered him; but on both occasions all the persons present are entertained with a meal.

Among the Arabs of the Hiaina the bridegroom has likewise his hands painted with henna on the day when the flour is sifted in his father's house; but it is done privately by women of his family, and round either hand is then tied a kerchief to prevent the henna from rubbing off. From this tying up of his hands the ceremony which takes place the same evening is called $r$-rbet. Men and women from his own and neighbouring villages are invited to take part in it. There is singing, playing, and feasting; the men eat first and the women afterwards, whilst the bridegroom has his meal in another house together with his bachelor friends, called islan, which is the plural form of the Berber word isli, "bridegroom." $\mathrm{He}$ has had his head shaved the same day, he is dressed in new clothes given to him by his parents, and on his feet he has a pair of new slippers bought with money out of the bride's share of the sdaq. After they all have eaten, he walks in a procession to the place where the people are assembled, with the islan behind him and two or three women fanning his face in front of him. He is now addressed as "Sultan," and close to him walks " the vizier" (l-uzîr). He wears a sword at his side, the hood of his cloak is pulled down over his eyes, his mouth is covered by the hây? slippers are pulled up. $\mathrm{He}$ sits down on a carpet (zarbîya) with a mézwud under him, so that he shall 
not be affected by bas (evil influences), or, as I was also told, that his own bas shall go into the sack. The vizier is standing on his right side keeping the hâyẹk of the Sultan in a fold under his chin so that the people can put money into it. Behind the Sultan a number of girls are making a quivering noise, and so is his sister or the other woman of his family who stands next to him keeping her hand round the point of his hood, over which has been slipped a silver bangle (démlijj), as among the Tsul. In front of him there is a palmetto tray (meidûna) covered with a silk kerchief (sěbnîya), on which has been placed a bowl (zlâfa) containing flour and rock-salt, the object of the latter being to protect the Sultan against $j n \bar{u} n$, or evil spirits. An elderly woman of his family, by preference his father's sister, keeps his bound-up right hand with the palm upwards in the bowl, and slowly rubs the kerchief covering it with flour. Meanwhile the girls are repeatedly singing :

\section{Mal îdak l-hâni yä háyyi,}

Extend your hand, the red one, $\mathrm{O}$ my brother.

The people are putting money on the table, in the bowl, and in the folds of the Sultan's hâyẹ̆k, while one of the islạn cries out, Allahh mia sîdi flạn, kättsár allàhu háirek a sîdi flạn, "May God be with my lord so-and so (mentioning the name of the donor), may God increase your wealth, $\mathrm{O}$ my lord so-and-so." They also try to knock money on the Sultan's head, but the young woman who is keeping his hood catches the blow and takes the money for herself. Some coins 
are likewise given to the girls who are making the quivering noise. The money put on the table is taken by the young man's parents, who buy with it sugar and candles for the wedding ; the money put into the bowl is for the woman who is rubbing his hand with flour; and that which is placed in the fold of his hâyẹk he keeps for himself. But the sums given on this occasion are not great. When the performance has come to an end, the vizier says, $\bar{A}$ men jâna ijih l-hair, "O he who has come to us, may wealth come to him." And the women sing :-Kättsár lláhu háirkum a lă-zâra kúllkum, "May God increase your wealth, $\mathrm{O}$ bachelors all of you." The Sultan gets up, some men who are carrying swords unsheath them to beat him, the vizier draws his master's sword to defend him, and they both run away in haste. ${ }^{1}$ While this is going on, some of the women are making a quivering noise.

On the evening of the following day, just before the bride arrives at her new home, the same ceremony is repeated, with the difference however that this time the flour, again mixed with salt, is rubbed on the bridegroom's bare hand, and that much more money is given than on the previous occasion. When the procession is coming, two of the islan go in front of the Sultan clashing their swords together, and the ceremony again ends with the flight of the Sultan and his vizier. It should be added that the bridegroom at the rbet carries on him some hármel (seed of Peganum Harmala), fâsoh̆

1 Among the Tsūl no attempts are made to beat the bridegroom, nor does he run away. 
(gum-ammoniac), rock-salt ( $l$-mélha l-háyya), and other charms against $j n \bar{u} n$; and both he and the islan paint their eyes with antimony and their lips with walnut root.

Among the Ulâd Bu-Ăzîz the bridegroom is painted with henna after the bride has arrived at her new home. While she and her female friends are sitting behind a curtain inside the bridegroom's tent, the following ceremony takes place in the yard. With his eyes and face hidden behind the hood of his cloak the bridegroom sits astride on a saddle which has been placed there for the purpose. He holds out his right hand, the palm of which is slowly smeared with henna by his aunt or sister or some other woman of his family, but not his mother. While this is going on, all the people present come one by one and drop a coin on the palmetto tray which is close by the bridegroom. In front of him is sitting a crier, L-berrth h, who with words of blessing calls out the names of the donors; and their praises are in addition sung by four women singers (mg்anniät), who stand behind the bridegroom each with a tambourine (târêja) in her hand. The money put on the tray becomes the property of the bridegroom, but the donors also give a small coin to the crier and the singers.

Among the Brâber of the Ait Warain the ceremony called lhänni támzziant, " the little henna," takes place on the day after the wheat has been ground. In the afternoon men and women of the village, as also friends 
from other villages, assemble in the house or tent of the bridegroom's father. The bachelors, who are particularly numerous on this occasion, sit together with the bridegroom in a room or tent by themselves. They have their supper first, then the other men, and lastly the women, the bridegroom's father attending to the male and his mother to the female guests. Whilst the mother remains with the women in the tent or room where they are sitting, the father retires before the arrival of the bridegroom and his bachelor companions. The young man has had his head shaved the same day. He wears a white cloak (dheddun, the Arabic sélhäm) with its hood drawn over his face-it must be white so that his days shall be white. Over his shoulder is hanging a sword ; and over his head two of the bachelorsthe future $\imath b e r r d h a ̈ n$ - are crossing their swords. He sits down on a tamzitt (the Arabic mézwud) placed on a new mat in the middle of the house or, if there is no house, in the yard (ásun) outside the tent. $\mathrm{He}$ is regarded as a sultan (djellid) and appoints one of the bachelors to be his vizier (luzîr); his most intimate bachelor friends bid for the post, and he gives it to the one who offers him the largest sum of money-a sum which is afterwards more or less refunded when the vizier gets married himself. What now follows is very similar to the corresponding ceremony in the Hiáina. On the right side of the Sultan stands his vizier and behind him a young sister of his, married or unmarried, keeping hold of the point (dilmus) of his hood, over which has been slipped a silver bangle (ademlij) as a 
means of bringing good luck, and making a quivering noise, while her brother is being painted with henna. In front of him there is a tray (tändutt) of palmetto or esparto, covered with a silk kerchief (tasebnist) on which is placed a bowl (táqnust) with henna. Close to the tray is sitting an aunt, maternal or paternal, of the bridegroom or, if he has none, some other elderly woman, by preference of his mother's kin, who slowly paints the palms of his hands with henna. In front of the tray stand two criers (ỉberrähän) crossing their swords and, when a person puts down money on the kerchief, calling out, "God be with so-and-so, he gave such-andsuch a sum"; but they only bestow this blessing on a donor who gives a coin to them also. The first coin however, which is given by a near relative of the bridegroom, is not put on the kerchief but into his right hand, where it is painted with henna; being of silver it is considered to bring good luck. The vizier collects the money, all the time taking notice of the donors and watching that the coins given correspond to the amount called out; but afterwards he gives it to the bridegroom, who distributes it among the bachelors so that they shall buy gunpowder with it. The people also remember the bridegroom's sister, who is standing behind him making the quivering noise, by putting coins between her lips. When the Sultan gets up, the bachelors who have been standing round him try to beat him gently with their hands or with sticks, while the vizier defends him, beating the aggressors in return; and at last they both escape to a roon in the house or 
to another tent, leaving the bachelors behind to break the bowl. This breaking of the bowl, and also the painting of the bridegroom with henna, the crossing of swords over his head, and the beating of him, are all ceremonies said to be calculated to remove or keep away evil. Later on the vizier calls the other bachelors to come and spend the night in the company of the Sultan, who early in the morning distributes among them the money handed over to him by the vizier, as said before.

After breakfast they all set out for a tour to neighbouring villages. The Sultan rides on a horse with a sword hanging by his side and the hood of his cloak drawn over his face. On his right walks the vizier, waving a silk kerchief towards his head as if he were a real sultan, and on his left a bachelor carrying a stick with a white flag representing the shereefian umbrella. In front of them walk the other bachelors discharging volleys of gunpowder when they approach and when they leave a village. The band are not only entertained with food in the villages they visit but also receive money and a live sheep, the money being collected by the vizier. While the Sultan, with the latter, remains in a village, he sends the other bachelors in small groups of four or five men in different directions to ask for money or, in default of such, some other present of every traveller they meet on the road; if he is a native of the tribe they actually compel him to contribute, whereas they are less exacting in the case of a stranger. Thus they travel about from village to village for seven 
days, and when they return from their tour, the money collected, as also that which is got by selling the sheep and other presents, is again divided among the bachelors, who buy gunpowder with it.

On the evening of the day when they come back there is "the great henna," Ihánni tamqqrant. The Sultan and his vizier hide themselves in some place outside the village, while the rest of the bachelors and the other guests are entertained with a big meal at the house of the bridegroom's father. After they have eaten the question is raised, "Where is the bridegroom?" The bachelors go to search for him; when he is found the vizier takes him on his back and runs away with him; but they are caught, and now they all walk in a procession to the house, two of the bachelors again crossing their swords over the bridegroom's head. On their arrival there the rrma, or huntsmen, form a ring and move slowly round their chief, who is in the centre. At a signal from him they all stop and fire off their guns at the same time, after which each of them throws his gun up into the air and catches it again when it falls down. This is done three times, while the women make their usual quivering noise. The bridegroom is then painted with henna with all the ceremonies of the former occasion, though the money now given is taken not by him but by his father. This time he wears his slippers with pulled-up backs. He is hastily carried away on the back of the vizier, while the other bachelors are again busy breaking the bowl; but they are caught and beaten by the latter, who in 
their turn are beaten by the vizier. The whole company then retire to the bridegroom's room, where they spend the night, remaining there till the bride arrives.

Among the Ait Nderr the ceremonies attending the painting of the bridegroom with henna are on the whole, though not in every detail, similar to the lhinni tamzziant of the Ait Waráin. On the morning of the day when it is going to take place, invitations are conveyed to neighbouring villages by two men of his family who ride about on horseback, one holding in his hand a stick to which is attached as a flag a kerchief bought for the bride with money from the ssdaq. Among the Ait Nderer the young man has not only his hands but also his feet smeared with henna by a married woman belonging to his family. When the painting is finished, he is carried away by the bachelors to the tent where they are going to spend the night together. One of the women puts the henna bowl on her head and dances with it, after which it is passed to other women, who dance with it in their turn; but the bowl is not allowed to fall.

Somewhat different are the corresponding ceremonies among the neighbouring Berbers of the Ait Sádden. On the day following the asgirt the bridegroom has his hands painted with henna on both sides, by either his sister or some female cousin of his. This, however, is done not in his own home but in the house of a relative or friend, and he is on that and following days taken about to many other houses to have his hands 
smeared with henna over and over again, so that at last they become quite black. He is entertained with a meal in the houses to which he is invited, and on the first day he puts some money in the vessel containing the henna, giving the largest sum the first time he is painted. This is often the only henna-ceremony to which the bridegroom is subject, but it also occurs that he is painted once more on the day when the bride is brought to his home, or one or two days later. The latter henna-ceremony, which is attended with the giving of money (lägramt, the Arabic grâma) on the part of the guests, is only performed if they are numerous; it is a matter of business, and is therefore often abstained from by people who are afraid of a reputation for greediness.

If it is decided that there shall be such a ceremony, the bridegroom with some friends, all on horseback, makes a tour to neighbouring villages on the morning of the day when the bride is going to be fetched from her home. They are called by the name imărâdün (sing. amărad), "inviters," which explains the object of their tour. The bridegroom has his face covered with his âban (hâyẹk) and the hood of the white aslham (sélhäm) in which he is dressed; a sword is hanging over his left shoulder, and the backs of his slippers are pulled up. He remains quiet while his friends, galloping on their horses, discharge two or three volleys of gunpowder in every village they visit. Later on in the day, when the guests have arrived, the bridegroom sits down outside his father's house. From a bowl contain- 
ing a silver bangle his sister, by preference a child, slowly smears a little henna on the palm of his right hand. Two iberr $\not h \ddot{d} n$, who are standing on either side of them crossing their swords, cry out, Alldh mia sidi $f \bar{d} n$, "God be with my lord so-and-so," every time a person puts down money on the tray (iswi) which has been placed near the bridegroom. Two other men, called imsnein, are sitting close to the tray, watching the amount of money given and putting it under a silk kerchief ; they afterwards give an account to the bridegroom of the donors and the sums they presented. Some money is also placed in the bowl containing the henna as a gift to the girl. All the time the women are singing and making their quivering noise.

Among the At Ubahthi the bridegroom is painted with henna only once, namely on the day before the bride is fetched from her home. It is done by a woman of his family, married or unmarried, but not old, who applies the henna both to his hands and the soles and tops of his feet. He has, as usual, the hood of his cloak drawn over his face, and the backs of his slippers are pulled up. Neither he nor any of his bachelor friends have swords, but he is protected against jnūn by carrying a pistol, as also by volleys of gunpowder discharged while he is on his way to the place outside his father's tent where he is painted with henna, and as long as the ceremony lasts. There is the usual quivering noise of women, and the giving of money (lägrâmett) in front of him, the contributions being laid 
on a tray covered with a silk kerchief (tásébniht), on which has been placed a raw egg to give good luck to the bridegroom and a good year to the community. In the bowl containing henna, on the other hand, no charm is put; nor is there any dancing with it after the painting is finished. The money is afterwards handed over by the best-man, or auzir ("vizier"), to the bridegroom, who gives part of it to the bride after their first intercourse in case he finds her a virgin. When the young man has been painted with henna, the auzir also smears some henna on the palms of his own hands, and the other bachelors make a line with it on their hands and clothes; the henna is supposed to partake of the bridegroom's baraka. When the ceremony is over, the bridegroom walks back to the tent from which he came. $\mathrm{He}$ and his bachelor friends are all collectively called islän, plural of $a s l i$, " bridegroom"; and here, as elsewhere, the bridegroom is regarded as a sultan.

Among the Ruâfa of the Ait Wäryâgäl, a week before the wedding, the bridegroom has his hands and feet painted with henna by a boy of his family-such as a son of his brother or uncle-who is a first-born child and has not yet had any brothers or sisters, whose parents are alive, and whose name is Muhammed. This painting is then repeated every evening; it is said that by being smeared with henna the young man is pardoned by God for his sins. $\mathrm{He}$ is now called ajeddid, "sultan," and his bachelor friends are called 
iuzîrẹn, "ministers." Accompanied by them and the boy, he spends the days in visiting his relatives and acquaintances in his own and other villages. In every house they are entertained with meat and bread, salt butter and bread, and bread and honey, and are obliged to eat a little of everything. In the evenings the iuzîrẹn amuse themselves with powder-play, while the girls are dancing at some distance from them, and they then retire to the bridegroom's house to sleep.

These visits are continued for a whole week before the day when the bride is taken to the bridegroom's house. All this time he affects great bashfulness; when the $i u z \hat{\imath} r \underline{n} n$ amuse themselves in his own village he himself avoids being seen, and whenever he appears in public his head is carefully covered with the hood of his cloak (ajeddjab, the Arabic jẹllăb), ${ }^{1}$ which must be black. He wears his slippers (iharkûsen) with the backs pulled up from the moment he is painted with henna for the first time till the bride has been brought to his house and he is going to pray before they have their first intercourse ; should they be removed or slip off during this period it is believed that he will get ill or die or lose some of his animals. For the same length of time he must abstain from washing himself; the iuzîrẹ̆n may wipe his face a little with a damp cloth,

1 The ${ }^{(\alpha)}$ jẹllạ́b, or $(d)$ jẹllạba, is a man's cloak of any material or colour, "made of a rectangular piece of stuff joined down the front, the upper portion being cut and ingeniously joined to form the hood. Arm-holes slit in the upper corners are supplemented by sleeves a few inches long, made out of the pieces cut out to form the hood. As the width of the made-up garment exceeds the length, the total length of the sleeves is ample, and the draping is perfect. There is usually a small pocket inside the front seam, and in North Morocco those of native cloth are frequently decorated . . . with tufts of silk, if not with embroidery" (Meakin, The Moors, p. $5^{8}$ sq.). 
but no water must be applied to any other part of his body, not even his hands-it is said that the painting with henna is his washing. If he prays during this time he makes his ablutions without water, either by touching a stone and then performing the usual motions with his hands or by making use of earth; and it is only when he is going to pray for the first time in the presence of the bride that he again makes an ablution with water. Nor is he allowed to change his clothes, except that he puts on a clean shirt for the great ceremony which takes place the evening before the bride is brought to his house.

There is then the so-called rhánni amáqqăran, "the great henna," attended by a large assembly of people. A pack-saddle is put in the yard (azqaq), and the women of the village (except the bride and her mother if they live there), as also the women who have come from other villages, sit down round the saddle, leaving an opening in the ring to allow the bridegroom to pass through. Accompanied by the iuzîtẹn firing off their guns, he comes to the yard and proceeds through the entrance of the ring to a young girl who is standing inside it holding in her hand a big bowl of henna. He dips the little finger of his right hand into the henna and then retires again. This is repeated three times. When he enters the ring of women for the fourth time, he sits down on the saddle, whilst the iuzîrẹn seat themselves outside the ring. On his right stands the young girl with the bowl, which besides henna contains a raw egg, so as to make his life "white"; 
she must be a girl whose parents are alive, by preference a daughter of the bridegroom's brother or of his paternal or maternal uncle. The men and boys enter one by one to present the bridegroom with money, each putting into his mouth a bilyun-piece of silver, or, if the donor is a grown-up man, several such coins, which he spits out into the bowl when his mouth gets filled. But it may also be that some man on this occasion makes him a present of several dollar-pieces, even as many as fifty or a hundred, which are thrown into his lap and then taken from there by his mother or sister, who puts them into the bowl. Such presents, however, are only given by persons who are engaged in blood-revenge and want to humiliate their enemy by showing their wealth. This may lead to a competition between the parties, in which one tries to surpass the other in liberality. The generous donor does not stand there alone, but has behind him his brothers ready to protect him against a revengeful foe, who may perchance be infuriated by his insolence. Instances have occurred in which a blood-feud has broken out on such an occasion in the yard, causing the women and the bridegroom himself to retire. When the giving of money is over, the girl who held the bowl is rewarded with a brlyūn or two, and also gets the egg, whilst the henna is taken and used by the women of the bridegroom's family.

Passing to the Berbers of Southern Morocco we notice that among the Igliwa of the Great Atlas the 
bridegroom has his hands daubed with henna on the three days preceding the bride's arrival; and all this time he is confined in his house, going to the top of it only when he hears the banging of guns heralding the coming of the bridal procession. In Aglu, in Sūs, the palm of his right hand is painted with henna by a woman of his family on the day when the bride is fetched; there is no grâma on this occasion. Among the Ait Támĕldu the bridegroom smears henna on the inside of the fingers of his right hand on the third evening after the bride has been brought to his house, the so-called $\ddot{u} d n \breve{e}$-lhănna; but he does so only in case his parents are dead. If they are alive he will be ashamed to make use of henna at his wedding.

The application of henna to the bridegroom is found not only in all the tribes with whose marriage ceremonies I am acquainted, ${ }^{1}$ but also in some of the towns. ${ }^{2}$ At Tangier, on the evening before the day when the bride arrives, there is a feast in the bridegroom's house, with music on various instruments performed by a band of awwâdin (literally "lute-players"); and on this occasion, which is called l-lîla del-ărûss, " the evening of the bridegroom," he dips the little finger of his right

1 See also Doutté, Merrákech (Paris, 1905), p. 333 sq. (Rahámna); Sạlmon, 'Une Tribu marocaine,' in Archives marocaines, i. (1904), p. 209 (Fahs) ; MichauxBellaire and Salmon, 'Les Tribus arabes de la vallée du Lekkoûs,' ibid. vi. (1906), p. 227 sqq. (Hlot and Tilq); Michaux-Bellaire, 'Quelques tribus de montagnes de 1a région du Habt,' ibid. xvii. (IgII), p. I 31 .

2 Michaux-Bellaire and Salmon, 'El-Qçar el-Kebir,' in Archives marocaines, vol. ii. no. ii. (1904), p. 69 ; Saîd Boulifa, Textes berbères en dialecte de l'Atlas marocain (Paris, 1908), p. 17 (Demnat). For Tangier, $c f$. Meakin, The Moors (London, 1902), p. 367 . 
hand into a bowl of henna which is held by one of the wazâra. The following morning he goes to the hot bath accompanied by three or four wazâra; but I am told that it formerly was the custom for him to have his bath on the morning of the day when he gave his feast.

The object of applying henna to the bridegroom ${ }^{1}$ is to purify him and protect him from evil influences; for henna is considered to contain much baraka, and is therefore used as a means of purification or protection on occasions when people think they are exposed to supernatural dangers, as for example at religious feasts. ${ }^{2}$ The bridegroom is supposed to be surrounded by such dangers; he is regarded as holy, which is emphasised by the title of Sultan so frequently given $\mathrm{him},{ }^{3}$ and

1 The application of henna to the bridegroom is also found among certain Berber tribes in Algeria (Gaudefroy-Demombynes, Les Cérémonies du mariage chez les indigènes de l'Algérie [Paris, 1901], p. 30 ; Destaing, Étude sur le dialecte berbère des BeniSnous [Paris, 1907], p. 288), at Aleppo in Syria (Guys, Un Dervich algérien en Syrie [Paris, 1854], p. 201), and among the Muhammedans of the Malay Peninsula (Skeat, Malay Magic [London, 1900], p. 375 sqq.) and India. With reference to the last-mentioned, Mrs. Meer Hassan Ali (Observations on the Mussulmauns of India, i. [London, 1832], p. 377 sqq.) states that long-established custom obliges the bride to send mayndhie (henna) to the bridegroom on the second night of the nuptials to be applied both to his hands and feet. According to Major Tremearne (Hausa Superstitions and Customs [London, 1913], p. 82), the bridegroom is stained with henna among the Hausas also.

2 See Westermarck, 'The Popular Ritual of the Great Feast in Morocco,' in Folk-Lore, xxii. (1911), p. 132 sqq.

3 This is the case not only in Morocco (see also Höst, Efterretninger om Marbkos og Fes [Kiфbenhavn, 1779], p. $9^{8}$; Mouliéras, Le Maroc inconnu, ii. 'Exploration des Djebala' [Oran, 1899], p. 495 ; Salmon, in Archives marocaines, i. 209 [Faḥs]; Michaux-Bellaire and Salmon, ibid. vi. 229 [Hुloṭ and TTliq] ; Doutté, op. cit. p. 333 [Raḩámna], but in Algeria as well (Gaudefroy-Demombynes, op. cit. p. 4I sq.; Destaing, op. cit. p. 289). In Syria the bridegroom and bride are regarded as king and queen (Wetzstein, 'Die syrische Dreschtafel,' in Zeitschrift für Ethnologie, v. [1873], p. 288), and in the Malay Peninsula they are called "sovereigns of a day" (Skeat, op. cit. p. 388). 
holiness implies not only that there is supernatural energy in the holy individual or object, but also that they are susceptible to all kinds of baleful influences, especially those of a supernatural kind, like evil spirits, magical tricks, and the evil eye.

We have seen that the henna is applied sometimes to the palm or fingers or little finger of the bridegroom's right hand, sometimes to both hands, and sometimes to his feet as well. The person who paints him may be either his best-man, or a first-born boy with the holy name Muhammed, or his sister, or some other young woman of his family, or an elderly female relative, by preference his aunt; but among the Ait Sádděn and Ait Yúsi he is painted by other persons besides, in the houses which he visits. The act is generally, but not everywhere, performed before the arrival of the bride. It is sometimes done privately, but more often publicly, and may be repeated more than once. In some tribes there are two henna-ceremonies, "the little henna" and "the great henna," and in others the bridegroom is painted every day for some time before the wedding. In one tribe he is not only privately smeared with henna, but his right hand, or the kerchief round it, is afterwards publicly rubbed with flour ; and that the latter ceremony is intended to serve the same purpose as the painting with henna is suggested by the fact that flour on other occasions is used as a means of purification or protection against jnunn. ${ }^{1}$ In

1 Westermarck, in Folk-Lore, xxii. (1911), p. 142 ; Idem, Ceremonies and Beliefs connected with Agriculture, etc., in Morocco, p. 50. 
certain tribes henna is not only applied to the bridegroom, but is used by his best-man or other bachelor friends as well, who smear it on their hands or clothes; and sometimes all of them paint their eyes and lips with antimony and walnut root, which are also supposed to contain baraka. ${ }^{1}$

The washing ${ }^{2}$ and shaving ${ }^{3}$ of the bridegroom and his dressing himself up in new clothes ${ }^{4}$ and new slippers may also be regarded as acts which have a purificatory import, ${ }^{5}$ though there are, no doubt, other than superstitious reasons for these practices. The beating of the bridegroom ${ }^{6}$ may be a ceremonial punishment inflicted on him by his bachelor friends because he is deserting their class, but it is expressly

1 See Westermarck, in Folk-Lore, xxii. 134.

2 It is a widespread custom that the bridegroom has a bath before meeting the bride. See Gaudefroy-Demombynes, op. cit. p. 40 sqq. (Tlemcen); Lane, Modern Egyptians, p. 180, and Idem, Arabian Society in the Middle Ages, p. 236 (Cairo); Klunzinger, Upper Egypt (London, 1878), p. 197; D'Arvieux, Travels in Arabia the Desart (London, 1718), p. 232 ; Van-Lennep, Bible Lands (London, 1875), p. 55 I (Palestine).

${ }^{3}$ Cf. Gaudefroy-Demombynes, op. cit. p. 4 I (Tlemcen); Klein, 'Mittheilungen uber Leben, Sitten und Gebräuchen der Fellachen in Palästina,' in Zeitschrift des Deutschen Palästina-Vereins, vi. (1883), p. 95 (peasants of Palestine).

4 Cf. Lane, Modern Egyptians, p. 180 ; D'Arvieux, op. cit. p. 232 ; Skeat, op. cit. p. 380 (Malay Peninsula).

5 Cf. Westermarck, in Folk-Lore, xxii. 132; Doutté, op. cit. p. 333 sq.

6 In Cairo, immediately before the bridegroom enters his house in order to meet the bride, "his friends leave him, but at parting strike him many times with their hands upon his back; these blows he endeavours to avoid by running in as fast as possible" (Burckhardt, Arabic Proverbs [London, 1830], p. 116). In ancient India the bridegroom was chaffed or beaten (Haas, 'Die Heirathsgebräuche der alten Inder,' in Weber's Indische Studien, v. [1862], pp. 300, 301, 41 I). In some parts of Germany he is beaten by the wedding-guests, especially the unmarried ones, "angeblich, damit er fühle, wie Schläge schmecken und seine Frau damit,verschone" (Sartori, op. cit. i. 88 sq.). Mannhardt, who gives many instances of the custom of beating a bridegroom or bride (Wald-und Feldkulte, i. [Berlin, 1875], p. 299 sqq.), suggests (p. 302) that its object is to expel evil spirits which might otherwise prevent fecundity. 
said to rid him of evil influences, and so is the breaking of the bowl by the bachelors or by the girl who painted him with henna $;^{1}$ even under ordinary circumstances it is the general belief in Morocco that, if an earthenware vessel falls down and breaks, its owner is thereby freed from his bas. The dancing with the bowl and the passing of it from head to head may likewise have a purificatory origin, as is the case with various other ceremonies consisting in some kind of motion, ${ }^{2}$ though it may at the same time be supposed to give those who dance with it the benefit of the bridegroom's baraka. The presence of burning candles ${ }^{3}$ and a bottle of water

1 At Bajār, when the marriage contract had been made, it was the custom for the guests to throw the bottles of rose-water which they had brought with them against the wall (Fraenkel, 'Aus orientalischen Quellen,' in Mitteilungen der Schlesischen Gesellschaft für Volkskunde, xix. [1908], p. 28). In his description of Jewish marriage ceremonies Addison (The Present State of the Ferws [London, 1676], p. 5 I) states that in some places "the young Men who wait upon the Bridegroom, at the hearing of the Husband giving the Missal Tob, or wishing happiness to his Wife, break certain small Earthen Pots which for that purpose they hold in their hands. And thereby signifie their good wishes of prosperity and health to the New-married Couple." Among the Jews of Morocco, according to the same author (p. 48), the Rabbi, after he has said the prayer which is called the nuptialblessing, "takes a Glass crowned with Wine, which having blessed and tasted of, he gives to the Bridegroom, who with a suddain Violence breaks it, in memory of the Destruction of the Temple." Nowadays, at Jewish weddings in Morocco, a glass of red wine is offered to the Rabbi, who tastes the wine and then "den Rest in einen Kübel ausgiesst, worin er schliesslich das Glas zerschlägt " (Jansen, 'Mitteilungen über die Juden in Marroko,' in Globus, lxxi. [1897], p. 360). At the German Polterabend it was the custom that "man in oder vor dem Hause der Braut lärmend Scherben hinwarf oder Töpfe zerbrach" (Samter, Geburt, Hochzeit und Tod [Leipzig \& Berlin, Igri], p. 60; Sartori, op. cit. i. 72). According to Sartori and Samter, the breaking of earthenware vessels on this occasion was intended partly to frighten away malevolent spirits by the noise, but partly also, perhaps, to serve as an offering to these spirits. As to the second of these suggestions, see infra, pp. 257 n. 2, 342 sq. On the European custom of breaking objects, and especially food-utensils, see also v. Schroeder, op. cit. p. 84 sq.

2 Westermarck, in Folk-Lore, xxii. 140, 158 sq9.; Idem, Ceremonies and Beliefs connected with Agriculture, etc., in Morocco, pp. 22, 95.

3 Among the Muhammedans of the Malay Peninsula a feature of the so-called "Henna Dance" "is a small cake of henna, which is contained in a brazen cup 
is also most probably intended to purify the bridegroom or to keep away evil spirits; fire and water are very common means of purification in Morocco $^{1}$ as elsewhere, the jnün love darkness and are terrified by light, ${ }^{2}$ and at Fez it is the custom for persons who are afraid of these spirits to have at night a vessel filled with water near their bed. In this connection may be mentioned the tradition of the Shi'ahs that the Prophet, before he gave his daughter in marriage to 'Ali, commanded her to fetch water and then sprinkled both her and 'Ali with it, invoking God to protect them and their offspring against the devil. ${ }^{3}$ We have seen that incantations against the devil also occur at the hennaceremony in Morocco. Moreover, the constant firing of guns, ${ }^{4}$ the loud music, and the quivering noise of women, especially of the one who keeps hold of the bridegroom's hood, obviously serve the purpose of purifying the atmosphere and frightening away evil spirits by the noise ${ }^{5}$ and, in the case of the powder-

and surrounded by candles. This cup is carried by the dancer, who has to keep turning it over and over without letting the candles be extinguished by the wind arising from the rapid motion" (Skeat, op. cit. p. 377).

1 Westermarck, Ceremonies and Beliefs connected with Agriculture, etc., in Morocco, pp. 67, 68, 79 sq9.; Idem, 'Midsummer Customs in Morocco,' in Folk-Lore, xvi. (1905), p. 40 sq.

2 Cf. Westermarck, "The Nature of the Arab Ginn, illustrated by the Present Beliefs of the People of Morocco,' in Fournal of the Anthropological Institute, xxix. (1900), p. 253.

3 Goldziher, 'Wasser als Dämonen abwehrendes Mittel,' in Archiv fiir Religionswissenschaft, xiii. (1910), p. 31 sq. Cf. Samter, Geburt, Hochzeit und Tod, pp. $67-89$.

4 For firing of guns at weddıngs, see Samter, op. cit. p. $4 \mathrm{I}$ sq9.; Idem, "Hochzeitsbräuche,' in Neue Fahrbulcher fïr das klassische Altertum, xix. (1907), p. 140 sq.

5 On the making of noise for the purpose of frightening away evil spirits, see Samter, in Neue Fahrbicher für das klassische Altertum, xix. 139 sq9.; Idem, Geburt, Hochzeit und Tod, p. $5^{8}$ sqq.; Sartori, op. cit. p. 71 sq. 
play, also by the smell of powder, of which the jnun are believed to be much afraid. For a similar reason the bridegroom carries a sword, ${ }^{1}$ dagger, or pistol ; and the crossing of swords over his head or in front of him is likewise intended to ward off $j n \bar{u} n$, who are afraid of steel and, especially, of weapons of this metal. The same is the case with his wearing of various charms and the use of salt, which is also a common safeguard against evil spirits. ${ }^{2}$ The hood pulled over the bridegroom's face and the hâyẹ̆k drawn over his mouth are further means of protecting him from baleful influences, especially the evil eye; and for a similar reason he is confined to his house and eats alone or in company with his family only, although his natural bashfulness, no doubt, has also something to do with all these practices. Being in a delicate condition he must not eat much nor sit on the ground, but must have underneath him a carpet and a sack or a saddle, and the backs of his slippers are pulled up so as to prevent their falling off and his feet coming into contact with the ground; sometimes, as we have seen, he is even carried away by his bachelor friends. ${ }^{3}$ But at the same time there is also a fear that the slippers might come into

1 Cf. Klunzinger, op. cit. p. $19^{8}$ (Upper Egypt).

2 See Westermarck, in Fournal of the Anthropological Institute, xxix. 255. On the use of salt at weddings, see Tremearne, Hausa Superstitions and Customs, p. 84; Crooke, Popular Religion and Folk-Lore of Northern India, ii. (Westminster, 1896), p. 23 ; Sartori, 'Der Schuh im Volksglauben,' in Zeitschrift des Vereins für Volkskunde, iv. (1894), p. 172 (Germany).

3 In Egypt, if the bridegroom be a youth or young man, one of his friends carries him a part of the way up to the harem; and Lane (Modern Egyptians, p. 182) says that this is done because " it is considered proper that he, as well as the bride, should exhibit some degree of bashfulness." Cf. Jaffur Shurreef, Qanoon-e-islam, or the Customs of the Mussulmans of India (Madras, I863), p. 84. 
the hands of an enemy who would harm him by working magic with them. ${ }^{1}$

Magical efficacy is attributed to the colour of the cloak worn by the bridegroom. Whilst in one case it must be black, presumably because the black colour is regarded as a protection against the evil eye, it is generally necessary that it should be white, partly, I believe, for the sake of purity, but professedly also in order to make his life bright. ${ }^{2}$ This custom leads us to a new class of practices connected with the hennaceremony, namely such as are intended not merely to keep off or expel evil influences but to bring more positive benefits. The white $\operatorname{~ggg~}^{3}$ which is put into the bowl or on the tray is expressly said to make the bridegroom's life white and happy, and in one instance to give a good year to the whole community. The silver bangle ${ }^{3}$ slipped over his hood or placed in the bowl or on the tray will bring him good luck or prosperity, not only on account of the value of the metal but on account of its whiteness, a quality which is constantly emphasised by the natives when they speak of silver as a charm for good luck. To the same class of practices belongs, at least in part, the giving of grama, consisting exclusively of silver coins, which frequently forms so conspicuous a part of the bride-

1 See infra, p. 290.

2 It appears from Euripides (Alcestis, 923) that in Attica, in the fourth century B.c., the bridegroom's dress was white.

3 Among some Algerian Berbers, at the henna-feast of the bridegroom, " on apporte deux ou trois plats, où un halkal (bracelet que les femmes portent à la cheville) a été posé sur une montagne de viande, d'ceufs et de beignets sefendj; il faut tout d'abord que le plus adroit des jeunes gens l'enlève, en échange d'une part dans les friandises amoncelées" (Gaudefroy-Demombynes, op. cit. p. 30). 
groom's henna-ceremony, though there are tribes (e.g. Andjra, Ait Yúsi, Aglu, and Ait Támęldu) in which it is not practised on this occasion. That the ceremony of $\dot{g} r a ̂ m a$ also has a magical meaning is indicated by the words said by the vizier when the money-giving has come to an end- "O he who has come to us may wealth come to him;" and its magical significance is, moreover, suggested by the painting of the first coin with henna, as also by the very formal character of the whole practice. The money given is really a loan which has to be repaid in the future under corresponding circumstances, or an indemnity for similar contributions in the past; hence the amounts given by the various donors are most carefully taken note of. Indeed, instances are even reported of prosecutions before the judge on account of unreturned grâma. ${ }^{1}$

We have still to notice certain ceremonies to which the bridegroom is subject before he goes to meet his bride.

In Andjra, after the musicians have given him a morning serenade, he comes out from his room and presents to the wazâra a live bullock, which they take away and kill ; and with the meat together with kísksu the guests are entertained on that day. There is "the

I See Michaux-Bellaire and Salmon, 'El-Qçar el-Kebir,' in Archives marocaines, ii. $70 \mathrm{n}, \mathrm{I}$. In Palestine "a feast generally takes place on the evening of the wedding, and the invited guests have to bring presents; a list of these and of their value is made, and when there is a wedding in the family of any of the donors, the bridegroom of this occasion has to give a present of similar value" (C. T. Wilson, Peasant Life in the Holy Land [London, 1906], p. 112). Cf. Guys, op. cit. p. 203 (Aleppo). 
CHAP.

baraka (holiness) of the Sultan" in that animal. The first part of it which is eaten is the liver, a little piece of it being given to every man and boy; but no woman is allowed to partake of it.

The bridegroom spends part of his day in the mosque of the village in company with his wazara. He feels bashful and, on leaving his refuge, sends some of his men to his mother to fetch a hâyẹk and four flags attached to bamboo canes. Covered up with the hâyệk and accompanied by the wazâra and the musicians playing their instruments, the bridegroom now marches to a spring to be washed clean of his henna -a ceremony called $l$-ǵsill del-hänna. The wazâra are singing :

Qáddemnah bă qdâmna, yâ mlẹh sálliu ‘ăl ắn-nbi la yișbăh,

We have made him our leader with our steps,

$O$ good people pray for the sake of the Prophet till it becomes morning.

On their way they are attacked by the married men, the so-called 'drab, "Arabs," who try to rob the wazâra of their flags and slippers and, if strong enough, even to make a prisoner of "the Sultan." If they succeed in catching him, the wazâra must promise to give a feast to the 'árab in order to be allowed to proceed to the spring. But there again the 'arab trouble the Sultan and his men, and a struggle ensues in which each party tries to throw the other into the spring. Should the Sultan be pushed into the water, it is believed

\footnotetext{
1 Instead of yâ mlgh, I have heard, in the Garbiya, wa 'lâmna, meaning " and our flag."
} 
that a little of his baraka would be imparted to the spring and remain there for the future.

After he is washed, he and his men go back to the mosque accompanied by the 'árab, who by this time have become quite peaceful. He enters the room of the $f q \tau$ inside the mosque, together with those wazâra who are scribes, and sits down there; whilst the 'arab outside are having an auction with the things they have captured, the wazâra now being obliged to buy them back with food brought there from the bridegroom's house. The Sultan's "vizier" brings some water, undresses his master, and wets the hair of his head, after which the $f q \bar{z}$ shaves it off while the musicians are playing outside the mosque. One of the wazâra goes to the bridegroom's mother to fetch the clothes which were sent for him as a present from his bride on the day of the $b \underline{d} \bar{u} \underline{d} e l-\breve{a} r \hat{u} \hat{u} a$, as also the hây him on the same occasion. ${ }^{1}$ The shaved-off hair is put inside his old clothes, and these are then taken to his mother, who envelops them in a kerchief and carries the bundle on her back "as if it were a baby." I was told that all such customs must be carefully observed, since otherwise Yiblis, the devil, would make husband and wife fight, being displeased with people getting married. It is easy to understand that the bridegroom's wearing of clothes presented to him by the bride and of the hâyệk in question (of which more will be said in next chapter) may be supposed to promote domestic peace; but as for the bundle carried by his mother on

1 See infra, p. 142 sq. 
her back, we have good reason to believe that it is really meant to be a magical means of making the marriage fruitful. The fight between the Arabs and the Sultan and his wazara no doubt emphasises the contrast between the married men and the bachelors, but it is probably, at the same time, a ceremony of purification, as is the case with the mock-fights on various other occasions. In this instance the purifying effect of the fight is of course increased by the circumstance that the parties try to throw each other into the spring.

Dressed in his new clothes, with a big turban and a silk cord round it on his head and covered with the hâyệ, which he wears pulled down over his face, the bridegroom goes outside the wall which encloses the harm of the mosque. There the vizier lifts him on to a saddled mule waiting for him. It is led by one of the ' $a r a b$ and surrounded and immediately followed by the wazâra, scribes, and shereefs, whilst the other people present walk behind, the musicians being the last. In front of the mule go the huntsmen, and on either side of it go three wazâra who are scribes, one waving a handkerchief to the bridegroom as is always done to the real Sultan when he is riding, and the others carrying flags. It is considered necessary that the persons who surround the bridegroom should be dressed in white clothes, as is generally the case with scribes. The procession moves slowly; the huntsmen are discharging volleys of gunpowder, the musicians are playing, and the scribes and wazâra are singing :- 
Yã Muhámmäd ya l-mudállal bt l-g̉amâma, ăléika salâmü llâh; u yā zeinû ĺămâma ăléika salâmù llâh,

O Muhammed $O$ he who is shaded by the veil, on you be the peace of God; and $\mathrm{O}$ beauty of the turban, on you be the peace of God.

This occasion is called $r$-rkub del-'ărûs, " the ride of the bridegroom," and the day in question nhar $r$-rkub del-'arriș. But as the bride is on the same day taken in an 'ammariya to her new home, it is also called nhar l-ammârîya.

If there is in the village a rada, or cairn, dedicated to the great mountain saint Mûläi 'Abdsslam, they bend their course thither; if not, they go to some other saintly place. Each member of the procession pelts the rduda with stones in order to drive away or kill Yiblis, who may easily accompany them on their way. After this ceremony of purification the bridegroom turns his mule towards the East, and, making fât $t^{5} h a$ with his hands, whispers:-Ana f harm alláh $u$ n-nbi Muhámmed, "I am under the protection of God and the Prophet Muhammed." He then faces Mûläi 'Abdsslam's mountain, whispering :- Ana f harm allah uf hadrmăk a mûläi 'Abdsslam, ărzáqni fü s-șáhha, "I am under the protection of God and under your protection O Mûläi "Abdsslam, give me health." All this is said in an inaudible voice, since the bridegroom is not permitted to speak aloud. The congregation likewise make $f \hat{a} t^{s} h a$, the $f q \bar{\imath}$ taking the lead. They now proceed to the bridegroom's house, accompanied at a distance by a crowd of women making their quivering noise. On their arrival at the yard a carpet from the 
bride's presents to the bridegroom is spread on the ground, the vizier lifts him from the mule and puts him down on the carpet, and there he sits reclining on a cushion (also given by the bride), surrounded by unmarried scribes from among his wazâra with flags in their hands. There is a continuous performance of music and powder-play lasting till about sunset, the procession having left the mosque at the time for the 'âșar prayer. Kǘsksu with meat is served to the congregation, especially good food being given to the wazâra, huntsmen, and musicians; but though the scribes who are sitting round the bridegroom partake of the meal, he himself abstains from eating. Three dishes of kứsksu with meat are sent by the bridegroom's mother to the mosque to be eaten by the $f q \bar{\tau}$ and schoolboys, who retired there when the performance in the yard came to an end.

After the meal the other people also leave the yard with the exception of the bridegroom and wazâra, some of whom, standing in front of their master, fire a few shots in the air. The bridegroom's mother brings four large candles, which are taken by the young men holding the flags, lighted by the vizier, and placed on the ground. The Sultan and his wazâra now perform their sunset prayer, and later on their evening prayer as well, sitting together all the time between the prayers.

Among the Ait Wäryâgäl the iuzîrẹ̆n, on the morning following " the great henna," shave the bridegroom's 
head and trim his beard, if he has any, after which they all have their breakfast. About midday they go out together, the bridegroom with his face covered as usual and carrying a basket filled with bread and meat. In the yard his mother has placed a mug ( $\underline{d} \dot{d} q \underline{d} \underline{h} \underline{t}$ ) upside down with a $\underline{d i}^{\prime}{ }^{1}{ }^{1}$ and an egg on the top of it, and the bridegroom now breaks both the mug and the egg with a kick, so as to destroy the evil. The iuzirẹnn fire off their guns, and the whole company, with the bridegroom in the centre, leave the yard. Outside it they are attacked by the married men and boys, who beat the iuzîręn with prickly-pear plants and try to rob the bridegroom of the basket. If they succeed, they eat its contents; whereas in the opposite case the bridegroom and iuzîrẹn go and have a meal together.

At Fez I have not heard of the custom of painting the bridegroom with henna, but the shaving of his head is, instead, attended with ceremonies and feasting. In the afternoon before the wedding-night, when the bride comes to her new home, or else on the previous evening, the bridegroom retires to the so-called dàr islän, a house which has been rented or lent for this occasion. He is accompanied there by a great number of male friends, more or less of his own age, married or unmarried, who drink tea and eat with him, while a band of alîyen amuse the company with their music. The older men, on the other hand, assemble in the house where the bridegroom is living, now called darr 
l-'yrs, "the house of the wedding," and are there entertained in a similar manner. After supper the family barber (hajjam) brings there a large wooden chair with painted designs, and tells some men of the bridegroom's relatives to fetch him from dar islann. $\mathrm{He}$ is then carried there by friends and accompanied by all the young men who were sitting with him. On his arrival at dar l'cors he is put down on the chair. To the house have been brought, as presents from some friend, two large round brass trays with feet (tiafar, sing. táifor), on one of which there is a heap of candles, whilst on the other is standing a brass bowl (tâsa) containing rose-water, myrtle twigs, and two or three small lemons of the kind called limun d-daqq. The mistress of the ngâgef ( $\left(-m^{\prime}\right.$ állma den-ngâagef) takes the bowl, which, like the heap of candles, has been kept under a conical cover (mkeb), and damps the bridegroom's hair with the wisp of myrtle twigs. The men now one after the other fix with spittle a large number of silver coins on his forehead and face, and even push coins between his lips; and for each person the barber's assistant, who acts as berrāah, or crier, calls out, Alláh m'a fän, "May God be with so-and-so." The barber knocks off the coins into a towel so as to give room for the next donor's contributions, and receives as his fee all this money, which, if the bridegroom belongs to a wealthy family, may even amount to one or two hundred dollars. After the end of this ceremony, which is called l-grâma 'al lă-'rîs $f$ Yyúlya, " the grâma on behalf of the bridegroom 
on the chair," the barber shaves the bridegroom's head and trims his beard, if he has any. He is then in great haste carried away by his friends to där islän; and now, about midnight, the bride is fetched from her home. All the time the aliyen have been playing.

Previous to this occasion, however, other less ceremonial preparations for the wedding have been going on in the bridegroom's house. A month or more after the sdaq has been paid, the young man sends a message to his fiancée's parents to inform them of the day when the wedding is to take place. The girl's mother then calls for the mistress of the ngâgef and orders her to hire a lot of mattresses and take them to the young man's house, as also to bring pearls to her daughter, telling her at the same time to keep herself disengaged on the day fixed for the wedding. A fortnight before that day there is the so-called $t^{s}$ inqil, "transportation." The mistress of the ngâgef, together with her assistants, takes to the girl's house one or more trays (tiafar) with a considerable quantity of agal-wood (' $\bar{u} d$ qmâri) and various other kinds of incense (qräs, tsabhêra, etc.), and a quilt (lhaf). Over the latter is put a muslin cover belonging to the girl, after which it is rolled up and, together with the tray or trays, in the afternoon taken by the ngâgef to the young man's house. They make a quivering noise outside the door, which is opened to them, and on entering the house they put down the things they carry and are entertained with tea and food. There is a feast going on with tabbâlats and female guests, and a 
similar feast is held in the girl's house; both these feasts are called $t^{s}$ anqil.

The next day the mistress of the ngâgef begins to send mattresses to the young man's house, and this is continued for the five following days. On the sixth day, which is called nhar l-far\}, the ngâgef with their mistress come there to put in order the nuptial chamber. By a wall of mattresses one end of the room is made into a special compartment, called dăḩ̌̌ǔsa, only large enough to hold a bed, whilst other mattresses are piled up along the back and side-wall of the outer and much larger part of the room, which is united with the daḩ̧ûsa by an opening left between the mattresses and the front wall. The piles of mattresses are of a considerable height, though they do not reach the roof, and on the top of them are placed tlâmat (sing. tsalmẹtta), or gold-embroidered covers. The visible side of each mattress is draped with sfaif-materials of different colours-and the uncovered parts of the walls above the piles are decorated with haitit, fancy stuff of European make. The floor is covered with carpets, and at the entrance of the room are hung two curtains, one of which is embroidered with gold. Many of these decorations, however, are not carried out on this occasion but two days before the wedding, on the day called nhar $z$-zina; this is the case with the covering of the mattresses with sfaif and the walls with hititi, the hanging of curtains at the entrance, and the laying of carpets on the floor. On nhar l-fars the muslin cover belonging to the girl is hung over the mattresses, 
to be removed again on nhar z-zîna, when they are draped with sfäif; and the quilt, which was likewise brought from her home, is put underneath the mattresses along one of the walls and turned double so as to be made thicker. On nhar $z$-zîna a mattress is placed in the dahȟûsa to serve as a bed for the young couple. 


\section{CHAPTER IV}

CEREMONIES IN THE BRIDE'S HOME

Meanwhile the bride also has to undergo certain ceremonies preparatory to the wedding.

At $\mathrm{Fez}$ she is purified both with water and henna. Five days before the wedding she goes in the afternoon to the hot bath, accompanied by some women of her family, one of whom carries a candlestick with a wax candle. When they enter the bath the candle is lighted, and the women make a quivering noiseobviously to ward off $j n \bar{u} n$, who are generally supposed to be haunting the hot baths. The same ceremony is again repeated on the following two days. On the latter of these occasions, that is, three days before the wedding, seven buckets of lukewarm water are poured over the girl by seven women, "so that she shall have no quarrel with her husband," in accordance with the saying, $L-m a$ dmān $u$-šarr mạ kän, "The water is safety and quarrel there is none." 1 This ceremony is called taqbtb, which means "pouring," and the day when it takes place is called nhar taqbib.

1 This saying is presumably a play on words, as the Berber word for water is aman, whilst the Arabic amän means "safety." 
On her return from the hot bath the girl sits down behind a curtain, which has been hung up in the room where she is living. She is there surrounded by unmarried girls of her family or kin, who sit and talk and drink tea and sup with her. After supper a miallma l-hännáya, or woman whose profession is to paint other women with henna, makes on her hands and feet a design called $l$-hänna be $t-t^{s} q w i \hat{s} a$, which is only made on brides. Round dots of henna are painted above the wrists and on the fingers, whilst the backs of the hands are partly, and the palms entirely, daubed with the same colouring matter; and the feet are painted in a similar manner. It is considered a bad omen if the painted parts become very red when they are rubbed clean the next morning, although on other occasions when henna is applied a strong red colour is much desired.

The following day is called qwâleb sgarr. On this day the female relatives of the girl assemble in the house, where a great feast is held, tabbâlat coming in the evening and playing till after sunrise, when they go away. The girl herself passes all this time behind the curtain in the company of her girl-friends, and is in the evening again painted with henna. The next day, which is called qwâleb kbār, some ngâgef come and dress the bride behind the curtain. When she is dressed she is led to the door of the room with her face covered, and lifted on to a low table. The ngâgef take the table on their shoulders with the bride seated on it, and dance about with their load in the middle of the house, singing : 
Hà hîya yä lâlla, hä hîya fi dírna,

Here she is $\mathrm{O}$ lady, here she is in our house.

This ceremony, which is called $d$-dôra, takes place in the evening, and as long as it lasts the tabbâlat are playing, and the other women are making a quivering noise. After a while the table is put down, and the girl retires to her room to have a short rest. She is then again led to the door of her room by the ngâgef, who there uncover her face, take hold of her shoulders, and move them gently to and fro, singing :

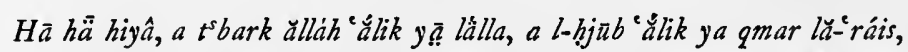

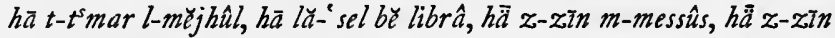
d̆ näs fiän,

Here, here she is, oh may trbark alláh be on you O lady, oh may the charms be on you $\mathrm{O}$ moon of the brides, here are the unheard of dates (an epithet ordinarily given by the people of Fez to the excellent dates of Tafilelt), here is honey bought for an [English] sovereign, here is beauty without salt (that is, the girl who has not yet had her face painted with cosmetics), here is the beauty of the so-and-so family (the name of the girl's family).

The phrase tsbark allahh, "may God be blessed," is a common charm against the evil eye," and is also used as such on this occasion. When this singing is finished the girl, who has all the time kept her eyes closed "out of shame," has her face covered again. The ngâgef sing :

\section{Hã hîya märhôna,}

Here is she who is pawned.

The girl's mother puts a small sum of money into a bowl which one of the ngâgef holds in her hand, lifts up

1 See Westermarck, 'The Magic Origin of Moorish Designs,' in Fournal of the Anthropological Institute, xxxiv. (1904), p. 211. 
the $i z a r^{1}$ which covers her daughter's face, and kisses her on both cheeks; she then drinks a little milk from a vessel held by another $n g g \hat{a} f a$ and takes a date from a bowl held by a third. All the other women present do the same one after the other. This is the so-called släm, "salutation." The money is meant as payment for the ngâgef; the object of the milk is, as before, ${ }^{2}$ to make the bride's life "white"; and the dates represent wealth. The whole of this ceremony is called $t^{s} a$ eye $q$, and it is considered obligatory on the women of related families to take part in it, since their presence is supposed to bring good luck to the bride. After the $t^{s} a^{\mathrm{c} Y} \hat{e} q$ is over the bride retires to her room with her girl-friends to have a short rest, the tabbâlat ${ }^{s}$ continuing to play and sing throughout the night and the guests remaining awake.

About daybreak the ngâgef place in the middle of the house a múnbar, or platform ascended by three steps, which has been brought from Sîdi Frạj the day before. The bride mounts it and sits down, whilst a $n g g \hat{a} f a$ is standing on each step and the others on the ground close to the múnbar. The htâtar, or female guests, now give presents, mostly consisting of clothing, to the bride. The present is handed to the nggâfa on the lowest step, who passes it to the one standing on the third, while the $n g g \hat{a} f a$ between them has her hands occupied by holding two wax candles ( $m \mathfrak{a} a ̂ a_{a}$, sing.

\footnotetext{
1 An $i z \ddot{a} r$ is a rectangular, seamless piece of material worn by women. On this garment see Dozy, Dictionnaire détaillé des noms des vêttements chez les Arabes (Amsterdam, 1845), p. 24 sqq.; Doutté, Merrâkech (Paris, 1905), p. 250 sq.

2 Supra, pp. 25, 27 sq.
} 
maš $d l)$. When the third nggâfa receives the gifts she cries out the names of the donors and calls down blessings on them, especially asking God to reward their children on similar occasions. Presents are given not only by the women, including the bride's mother, but also by male relatives and by friends of her father, who send their gifts by female proxies. While the presents are being given the women make a quivering noise. This ceremony is called l-múnbar, and the giving of presents is called l-grama ful $l$-múnbar. The clothes are enveloped in an izar by the ngâgef and handed over to the bride's mother. After the múnbar has come to an end the tabbâlats go away, but the htâtar remain. From her elevated place the bride retires to her room and spends the remainder of the day in the company of her girl-friends till about midnight, when she goes to the bridegroom's house. This day is called bits r-ráhha, "the room of rest," but it is also called nhar l-örs, because the wedding proper is then celebrated in the bridegroom's house.

In the afternoon all the women, including the bride, go upstairs leaving the ground-floor for the men. The male relatives of the bride's parents and other male friends of the father come there as invited guests; they are entertained with music of alîyen, tea, and nice food, and remain sitting there till the bridegroom's party come to fetch the bride.

At Tangier the bride is, in the evening of the fourth day before she leaves her old home, taken to the hot 
bath by female friends, both girls and married women. This evening is called l-lîla del-hạmmạm, "the evening of the hot bath."

In the evening of the next day, which is nhar $d$-dbeh $a,{ }^{1}$ the girl is carried by a black woman (ḩâderm), called the $n g g \hat{a} f a$, to the room in the house where she is now going to be painted with henna. The nggâfa holds up a little table on which there is a bowl with henna covered with a kerchief. A fqîra, or female musician, mixes the henna with water, and while stirring sings a song, accompanied by her six assistants on their instruments. The henna-mixture is then applied to the girl's hands and feet by a married woman who must have been married to a bachelor and not been married

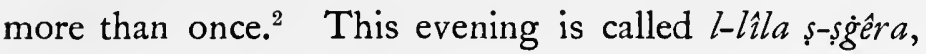

${ }^{1}$ See supra, p. 78.

2 The Shareefa of Wazan (My Life Story [London, 1911], p. 126 sq.) gives the following description of the painting of a bride with henna at Tangier :- "The leaves are dried and ground to a very fine powder, then sifted, and next put into a large basin. Hot water is stirred in until it becomes the consistency of a batter. For the feet, sandals are simulated by first arranging calico straps on the foot and round the base of the big toe. The henna paste is applied with care so as not to mar the symmetry of the straps; once the foot is well covered with paste, white cloths are wrapped round, and over that thick woollen ones. These coverings are not removed for some hours, when the paste generally comes off with the coverings. The rolled calico is removed, and a red-brown sandalled foot is presented. Sometimes the simulated shape received a decoration by a lace-work pattern being painted on the lines in 'Harkos,' a kind of Indian ink, which lasts for a long time. This is applied with a pointed cane pen. The process is long, as I can personally testify ; nevertheless it is most effective when well done. The hands to be henna-stained are treated in several ways, according to individual fancy. You may rub them well in the paste and dry them over the fire, or they may be carefully anointed, special care being taken to have no cracks. The nails receive an extra dose of paste, and are then wrapped in cloths. Sometimes a professional stainer will be summoned, and patterns will be designed with henna paste, which must be dried over a charcoal fire. This takes a very long time, and one can but admire the effect produced afterwards, especially when the design is interwoven with the delicate tracing of ' $\mathrm{E} 1$ Harkos." " 
"the little evening." The next day is l-lîla l-kbîra, "the great evening," when the painting of the bride with henna is repeated at the feast which is then given in her house with a large number of invited guests. Nowadays the henna-ceremony is mostly omitted on the former occasion, l-lîla s-sgêra, though there is still a small feast attended by relatives and intimate friends.

The day after l-lîla l-kbîra is called d-djwâri, " the neighbours." On this day there is giving of money (ǵrâma) for the benefit of the fqîra, the bride's mother being the first donor, and the other women following her example. There is no general feasting on this occasion, but food is given to the fqîra and her assistants, and tea and buns (fqâqaș) to all young married women present who have not yet been to a wedding since their own. They have come there dressed in their bridal costumes and are called $l-a$ arais, " the brides."

Among the country people certain ceremonies likewise take place in the bride's home before the wedding proper. In Andjra these ceremonies commence with

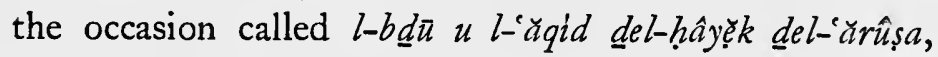
" the bride's beginning and tying of the hâyệ," three days before she is fetched by the bridegroom's people. Her girl-friends, the so-called wazâra or wúzra, make a canopy of blankets in the yard. Underneath it is placed a mattress on which the bride seats herself, with covered face and dressed in the new hâyẹk which she has this same day received from her betrothed. The wazâra sit down round her, and a married woman who 
is her husband's first and only wife, much beloved by him and blessed with children, plaits the fringe of the hâyẹk. A fqîra and her assistants are singing and

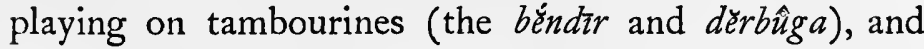
the wazâra join in the singing, while the bride is weeping. When this has been going on for a couple of hours, a meal is served to the wazâra. The hâyệk is the same day sent back to the young man, together with a big white turban, a silk cord (mésmär) to tie round it, two shirts, a qdftan, ${ }^{1}$ and a pair of trousers as presents from his fiancée. As we have seen, he subsequently wears this hâyẹk on the occasion when he proceeds to his house before he has the first intercourse with the bride. I was told that the ceremony of tying the fringe of the hâyẹk is intended to make the bride as fortunate as the married woman by whom it is performed - a mother of children and dear to her husband ; and this well agrees with what I take to be the object of the act of tying itself, namely, to strengthen the marriage tie. ${ }^{2}$ After the wedding the husband gives the hâyệk as a present to his wife, who keeps it in her box, though she may use it at any time she likes. The suggestion was made that by keeping the hâỵ̨k the baraka of the wedding is preserved in the house.

In the evening there is a feast in the girl's house, with only women as guests. Sitting on her bed, the

I A qáftän is a garment of coloured material which is worn by men and women over the shirt or chemise; it has wide sleeves and is buttoned all down the front. On this garment see Meakin, An Introduction to the Arabic of Morocco (London, 1891), p. 51 ; Idem, The Moors (London, 1902), p. 61 sq. ; Lerchundi, Vocabulario español-arábigo del dialecto de Marruecos (Tánger, 1892), p. 158.

2 Cf. infra, p. 260 sq. 
bride weeps and wails, mentioning by name every member of her family whom she is now going to leave. Then the wazâra dance. The bride's mother brings a bowl of henna and four candles in it, as also a waterbottle. One of the wazâra takes the bowl and mixes the henna with water, whilst four others take hold of the candles, which they light. The bride is lifted from her bed and has henna smeared on her hands and feet, the wazâra standing round her. After this is done she is again carried to her bed, and the wazâra resume the dancing. They must remain awake all night long lest the married women should get an opportunity to steal anything from the bride. This occasion is called l-lîla s-șérê del-'ărûsa, " the bride's little night."

After a short sleep in the morning the wazâra have their breakfast and the bride also, but custom requires that she should eat only a little-just an egg and a piece of bread. She is then washed with warm water and dressed in fine clothes and weeps, as she did the day before. The wazâra sing and dance till the afternoon when $l-\dot{g} d a$, or lunch, is served out of food brought from other households. It is the custom that on this day women from all the houses in which there is an unmarried girl bring to the bride a dish of küsksu with meat or milk, hence the day is called lă-ǵdîya del-ărûsa. A portion of the food is sent to the $f q \bar{i}$ and scribes in the mosque, whilst another portion, a particularly nice dish, is taken to the bridegroom, if he lives in the neighbourhood; otherwise only bread is sent to him. This is regarded as 
'ahd, or an act of covenanting, between bride and bridegroom. ${ }^{1}$ He has meanwhile ordered tabbâla and gaiyâda to go to his betrothed's house to play there at night. While they are playing the bride is weeping in her room, and so are her wazâra, who are sitting with her.

After supper the bride and the wazâra go together on a tour from house to house, accompanied by the young men of the village, who at short intervals fire off their guns; and wherever they go they are received with milk and food as "hospitality" ( $t^{s}$ ádvef) given to the bride. When they come back she is carried by her wazâra through the door of her house and placed on her bed. After this the wazâra leave her alone, and have a dance outside the house, one of them balancing on her head a bowl containing henna, a raw egg, and four burning candles. The bowl is then passed on to the head of another girl, and so forth; and anybody who should allow it to fall down and break would be obliged to entertain the other wazâra with a feast-at the expense, however, of the bride-since it is believed that otherwise that girl would never marry. The raw egg is eventually eaten by one of the girls who wants to get a husband soon. When the dance is over the wazâra enter the room where the bride is lying, and she is now a second time painted with henna, with ceremonies similar to those of the evening before, but

1 The Moorish ' $a$ hd derives its binding force from the idea that the covenanting parties transfer conditional curses to one another by a material medium, such as, e.g., food (Westermarck, ' $L$-âr, or the Transference of Conditional Curses in Morocco,' in Anthropological Essays presented to E. B. Tylor [Oxford, 1907], p. 373 sq.). See infra, p. 259. 
with more feasting. This occasion is called l-lîla l-kbîra del-'arrîsa, " the bride's great night."

The next morning the bride is washed and dressed in a new costume, and the musicians give her a morning serenade (keișábbha 'ălă l-ărûssa). On this day the bullock is sent by the bridegroom, as said before. The married women, both of the bride's own village and of neighbouring villages, assemble in her house. They give grama to her mother, who afterwards gives the money to her daughter, and to the fqir $r a$ as well, and are entertained with meat of the bullock. This day, on which the festivities in the bride's house come to an end, is called nhar d-djwâri del-arrụ̂a, " the bride's day of the neighbours."

Among the Tsal the bride is painted with henna on the evening before the day when she is taken from her old home. A young woman applies the paint to her hands and feet on both sides, while her sisters and cousins tie with silk cords two one-bǐlyu un pieces round the little and third fingers of her hands, and other women put in her lap some coins, which she afterwards gives to her mother. During this ceremony she has no belt round her, and she remains without it for a week. ${ }^{1}$ The painting is followed by a meal of sekssu and mutton, the women eating with the bride in her room and the men in another room or in the yard. The sheep which her father killed for this occasion was previously ridden by the bride, who gave it seven boxes on its ears, while her

1 See infra, p. 293. 
mother removed its right eye with a big needle. The dried eye is afterwards made into powder and, mixed with various spices, put into the food which the mother gives to the bridegroom's family to eat, so that they shall look upon her daughter with affectionate eyes. Before the bride leaves her old home her mother also makes little cuts with a knife between her eyes, on the tips of her nose and tongue, at her right shoulder-joint and all other joints of the right side of her body, and at her vulva. The blood from these cuts is wiped away with cotton-wool, which the bride takes with her to her new home and puts into water together with a few dates, after she has had her first intercourse with her spouse; and when he comes to her the following night she gives him the dates to eat in order to make him a loving husband.

In the Hiaina, on the evening before the bride is taken away, she is the chief figure in a ceremony which is very similar to that taking place the same evening at the bridegroom's house, with the difference, however, that she is publicly smeared with henna, not with flour. This ceremony is also called $r-r b \bar{t} t$; it is the $r b \bar{t} t$ of the bride. The henna is mixed with salt, and she has her hands and feet painted with it on both sides by her mother or some other elderly woman of her family. The backs of her slippers (rähîya) have been pulled up, round the wrist of her right hand has been tied a perforated silver coin sent by the bridegroom to serve as a protection against $j n \bar{u} n$, and over her face she has a silk 
CHAP.

kerchief; her eyes must be covered, because it is believed that misfortune would befall any person or animal the bride looked at before she has seen her husband on her arrival at his house. At her right side stands her uzîra, and behind her a woman making a quivering noise; but no swords are crossed over her head. There is playing and singing and the giving of grama. The bridegroom also sends her some money, or, if he lives in the neighbourhood, comes there himself with the islan after his own rbet, and puts coins on the tray, in the bowl of henna, between the lips of the bride, and on her head, the last being a present for the woman behind. When the painting of the bride has come to an end, the women sing the same song as is sung on the corresponding occasion at the bridegroom's rbet, and the bride is carried away by the uzira and other girls.

Among the Bråber of the Ait Warain, on the evening when "the great henna" takes place at the bridegroom's house the bride is painted in her home, where a feast is likewise held, though on a smaller scale. She is dressed in her bridal costume, consisting of new clothes; she has no belt (astau), the backs of her slippers (iiherkîsin) are pulled up, her hair is dishevelled, and on her head she has a so-called lqobbt, that is, a bent cane to which is attached a red ${ }^{1}$ silk kerchief hanging down in front of her face and a green one behind. Thus dressed she has the palms and backs of her hands

1 On the use of red in wedding ceremonies see Zachariae, ' $\mathrm{Zum}$ altindischen Hochzeitsritual,' in Vienna Oriental Fournal, xvii. (1903), p. 230 sqg. 
painted with henna by her mother or maternal aunt, in the presence of women and children only, and all the time she is weeping. Some of the women put silver coins on the tray close to her, though the sums are smaller than those given at the bridegroom's feast; and on this occasion, also, the henna bowl is broken when the painting is over. The guests, among whom there are men from the village, although these are not allowed to see the ceremony itself, are only entertained with gruel (tdịrirt) made with salt butter.

Among the Ait Ndēr, on the other hand, the bride is painted with henna in the presence of both men and women, sitting on her bed inside the tent. There is the usual money-giving, swords are crossed over her head, and when the painting is finished there is the same dancing with the bowl as at the bridegroom's feast. Like the latter, the bride in many cases has a bath before the hen na-ceremony, though this is not obligatory; and she has the backs of her slippers pulled up. If she has her home far away from the bridegroom's village, she is only painted with henna at the same time as he on her arrival there.

Among the Ait Yúsi a feast called tagyrt is held in the bride's home on the evening when the bridegroom's party have come to fetch her. About midnight henna is slowly pounded by a sister of the bridegroom or bride, or some other female relative, while songs are sung by all the people present. The woman 
who pounds the henna must be a married woman, but one who has been married only once, as it is believed that if she had been divorced by a former husband the same thing would also happen to the bride. She mixes the pounded henna with water and paints with the mixture the bride's legs below the knee and her feet on both sides. The new slippers (rréhit) sent by the bridegroom are then put on her feet; but before this is done some salt, a needle, a silver coin, and a date or raisin are placed in the right slipper-the salt and needle presumably to protect her against $j n \bar{u} n,{ }^{1}$ the silver in order that she shall be "white" like silver, and the date or raisin that she shall become "sweet" or dear to her husband's family. For this purpose she puts the date or raisin, as also the salt, into the food eaten by them for supper a week afterwards, when she for the first time removes her slippers from her feet. Until then she wears them with the backs pulled up, so as to prevent them from falling off; it is believed that anybody who should get hold of earth trodden upon by the naked foot of a bride might work magic with it, whereas there is no such danger in footprints made by her slippers. ${ }^{2}$ When she removes them she also carefully shakes out the henna-powder and throws it into water, in order that it shall not be used for magical purposes against her.

I The oid Ait Yúsi woman who told me of this pretended at first that she did not know the object of the sait and needle, but subsequently, when I again asked her about it, said that they were put there as charms against the evil eye. I have little doubt that she gave these answers because she was afraid of mentioning the jnün.

2 On the "sympathetic power" of footprints see Sartori, "Der Schuh im Volksglauben,' in Zeitschrift des Vereins für Volkskunde, iv. (1894), p. 4 I. 
After henna has been smeared on the bride's feet the same is done to her hands, arms, hair, and face. An egg enveloped in a kerchief (aȟenbus') is tied round her forehead; it is then broken by the woman who painted her, and is left there till the next morning when the bride is washed. This is done in order that her hymen shall be broken by her husband as easily as was the egg. ${ }^{1}$ After the woman has painted the bride she sprinkles henna on some bachelors or married young men, even as many as five or six, who are thereby appointed to be the bride's imsnein; these young men are chosen with regard paid to their wealth, since they are expected to give money to the bride when the wedding is over.

Next morning the woman who painted the bride washes her with water containing some henna, while she is seated on a weaving-stool (if iggg $^{\prime} g^{y} e n$ ) and a pack-saddle (tabard $\underline{d} a$ ). By riding the latter the bride is believed to gain power over her husband, as a person rules over the donkey or mule he is riding, whilst the washing on the weaving-stool is intended to remove the átqqăf (the Arabic $t^{s} q a f$ ) which was imposed on her in her early childhood. Among the Ait Yúsi it is the custom for every little girl to be taken on one occasion three times underneath the two upper cross-bars

1 Cf. Customs and Manners of the Women of Persia, trans, by James Atkinson (London, 1832), p. 71 :- "Dadeh Bazm Ará says, the bride should take a hen's egg in her hand, and on getting up throw it against the wall to break it, keeping her face towards the Kibleh, or in the direction of Mecca. Kulsúm Naneh thinks that a useless proceeding, and recommends a needle to be presented to her on her marriage." Addison (The Present State of the Ferws [London, 1676], p. 52) says that among the Jews of Morocco the bridegroom on the marriage-day "takes a raw Egg, which he casts at the Bride ; intimating thereby his desire that she may have both an easie and joyful Child-birth." 


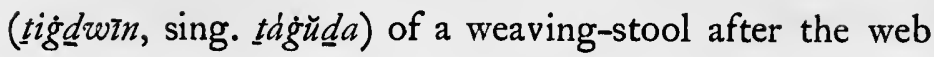
is ready, in order that no man shall be able to destroy her virginity, and the magical effect of this ceremony must naturally be cancelled before her wedding. After the bride has been washed she is dressed in the clothes sent to her by the bridegroom. The lizar (the Arabic izar) is not put on her in the ordinary way, but thrown over her left shoulder as if she were a man, whilst over her right shoulder is slung a dagger (asariy) hanging down on her left side. This dagger, which belongs to some unmarried young man, and is said to serve as a protection against magic, ${ }^{1}$ and also the lizar and the tamernșir $i t^{2}$ underneath, remain on her till the occasion when she is girdled. Her hair is covered with the ahernbus, over which is put the țášbnnt falling in front of her face as a veil. On the top of these kerchiefs is drawn the lizar, which is tied round the crown of her head with the lhăzdm (belt) and on which is painted with $z z^{i}$ afran (saffron) a broad circle called áyyur, "moon." Over the lizar is put a tahĕddunt, or mantle, presented to her by her parents, who also give her a carpet (țarrhalt) and an algrild (in Arabic mézwud). She is then ready to be taken away by the bridegroom's party.

Among the Ait Sádden, some days before the wedding, the young man sends to his bride a small sum of money, called tásdat. She puts this money under-

1 Cf. supra, p. 150 n. 1.

2 A tamenșürtt (the Arabic manșürîya) is a kind of chemise with sleeves, which opens in front down to the waist. On this garment see Meakin, The Moors, p. 61 ; Doutté, op. cit. p. 3 I 3 . 
neath the handmill when she performs the ceremony called izüd óhrir, "the flour of the àhir," consisting in her grinding some wheat with the handmill placed so that the flour falls over her uncovered right thigh. The grinding is subsequently continued by other women, and out of the flour is made ahrir, a kind of gruel prepared with salt butter, on the day before the bride leaves her old home. It is made with water brought early in the morning from a spring or well by seven girls who have gone there each with her aiddid, or goatskin bottle, in company with the bride. The latter fills all the bottles with water, after which she undresses herself and gets into the spring, or, if the bottom is too muddy, sits down on its edge; and the seven girls pour water over her and wash her body, hoping that by so doing they will get married themselves.

On the evening of the 'same day after sunset the bride's hands, feet, and head are smeared with henna, her lips are painted with walnut bark or root (lmswạh her eyes with antimony (tázillt), her cheeks with ochre $\left(l^{e} a k k^{y} a r\right)$, and on her face is made a design with saffron ( $z z^{\circ}$ afran), consisting of two lines, resembling whiskers, which are extended over the eyebrows and joined with a third line drawn along the ridge of the nose. The painting with saffron, which is called izriran, is, like the other kinds of painting just mentioned, applied not only to the bride but to other women as well, married and unmarried, who take part in the wedding.

Next day the bride is dressed in the clothes brought 
CHAP.

by the bridegroom's party, who have now come to fetch her, though they have been previously bought by her own parents with the ssdaq paid for her. The bridegroom's mother and sisters take in the clothes and dress the bride in them, and when this has been done the mother sings :

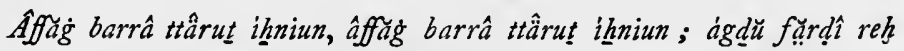

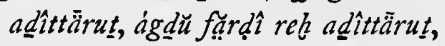

Go out may you give birth to male twins, go out may you give birth to male twins; even one [son] I wish you to give birth to, even one [son] I wish you to give birth to.

Before the bride leaves the room she has a broad line painted with saffron on the lizar round the top of her head. The reason for this was not stated, but considering that charms for persons who are troubled with inselmen $(j n \bar{u} n)$ are frequently written with saffron, it seems probable that the custom in question was originally intended to protect the bride against these spirits. So much importance is attached to it that it is practised even in the case of a widow bride, although she is not painted with henna. While the bride is being dressed the men are entertained with ahrir (a kind of porridge), no ttăcâm (sěksu) being served on this occasion.

Dressed in her bridal attire she goes out of the room and sits down on a mat to be painted with henna. Her mother or sister slips a silver leg-ring (țisðğněst) round the top of her lizar, and from a bowl in which has been put a silver bangle her sister slowly smears some henna on the palm of her right hand, while the other women are singing antiphonally : 
Go out may you give birth to male twins, go out may you give birth to male twins, and,

Even one [son] I wish you to give birth to, even one [son] I wish you to give birth to.

They are also making their usual quivering noise. The men give lăgramt (the Arabic grâma), and the women are meanwhile partaking of a meal of ahrir. When the money sent by the bridegroom with the imsnein is presented as the first gift, the two iberráhăn, who are crossing their swords over the bride's head, cry out, Alláh mia mûläi ssltan, "God be with my lord the Sultan." Two men of the bride's family are watching the amount contributed by each donor, all the money given on this occasion becoming her property.

Among the At Ubáhti the bride is painted with henna on the evening before the wedding. This act, which is performed by a woman of her family, must not be witnessed by men, nor is any giving of money connected with it ; but a substantial supper is served to the assembled people. Before the henna-ceremony the bride, like the bridegroom, has a bath.

Among the Ait Wäryâgäl it is the custom not only for the bridegroom but also for the bride to make a tour every day for a whole week before the wedding. Accompanied by the unmarried girls of the village, the so-called diuzîrin, she pays visits to her relatives in her own and neighbouring villages, but the nights they all pass together in her house. Every evening the bride 
has her hands and feet painted with henna by a girl of her family, a niece or cousin, who is a first-born child and has not yet had any brothers or sisters, whose parents are alive, and whose name is Fațîma; and at the same time the diuzîrin likewise daub their hands and feet with henna. Like the bridegroom's party the bride and her friends are entertained with food in every house they visit, and are obliged to eat a little of everything offered them. Should the two parties happen to meet in the same house, they do not mix together but sit in different rooms. The bride, also, must all this time affect great bashfulness; she has her head covered with a hâyẹ̆k, and the backs of her slippers are pulled up. The last evening there is a feast in her father's house with relatives and villagers as guests - an occasion which, like the feast simultaneously given in the bridegroom's house, is called rhănni amáqqăran. On this day the bride washes herself thoroughly with hot water.

Among the Shlöh of Aglu the bride stays in her room for two days before she is taken to her new home, doing nothing but eating and talking with her girl-friends. Previous to her departure she is painted with henna by her luzîra, a black woman who, like the nggâfa at Tangier, throughout the wedding acts as her attendant. The palms of her hands are smeared all over with it, designs are painted on their backs, and a line is drawn round the sides of her feet and over the toes. She is also dressed in her bridal costume, which 
includes the lizar brought by the bridegroom's people ; and while she is being dressed, custom requires that she should weep.

Among the Ait Támeldu it is the custom that, after the henna has been brought by the inddlaben to the girl's father, she stains her hands and feet with it over and over again, and her example is followed by her girl-friends. Subsequently, on the evening of the third day after she has moved to the bridegroom's house, she again paints herself with it, and so do all the other women present. This evening is called $\ddot{u} d n \ddot{e}$-lhanna.

Among the Igliwa the bride is confined in her house for three days before she leaves her home. During this time she has her hands and feet painted with henna on both sides every morning and evening, and a little of it is smeared on her arms.

At Amzmủz I was told that the bride's brother puts her slippers on her feet after he has placed a silver coin in the right one, and then taps her three times with his own slipper; but her girl-friends beat him in return so that he runs away. Here also the bride is crying aloud while she is being dressed.

Among the Arabs of the Ulâd Bu-Ăzîz the ceremonies of the evening before the bride's departure differ from those hitherto mentioned in so far that the bridegroom then has intercourse with her. A feast called $l-b a t t t a$ is given by her parents with the people of the village as guests. Before the slaughter of the ram which is to provide meat for the supper, the bride 
mounts it and boxes its ears in order that she shall rule over her husband, the latter being represented by the ram. After dismounting, she plucks out from it some eyelashes, so that her husband shall not get angry with her, and she hangs on it a necklace of glass beads (mdejja) with a view to making her husband weak and harmless like a woman. Before the ram is killed the necklace is removed by the slaughterer-the bride's brother or some other man,-who hangs it round his own neck, returning it to the girl after he has cut the animal's throat. Its stomach is taken out and placed in a wooden dish ( $g a s^{\prime} a$ ), and the bride puts her right foot on it, again for the purpose of making herself the ruler of the home. Lastly she takes the animal's heart and eats the whole of it the same evening, in order that the husband shall have a loving heart. The slaughter of the ram takes place in the afternoon.

Later on the same day the bride has the palms of her hands and the tops of her feet painted with henna by her maiden friends; she puts on a clean chemise (qmújja) and goes, accompanied by her friends, into a tent or straw-hut (nwậla) prepared for this occasion. There she finds the bridegroom sitting alone; he had previously entered with one or more bachelor friends, but the latter went away after the supper of sěksu and meat was offered them. The bridegroom gives some dates, walnuts, and almonds to the bride to make her friendly, and also to the other girls, after which the couple are left alone. They now have sexual intercourse. Before the connection the bridegroom gently 
smacks the bride, " in order that she shall always be afraid of him "; and after it the more beautiful of the two performs the usual ablution before the other, since it is believed that the children will resemble the parent who on this occasion washes first. If there is blood on the chemise of the bride, the bridegroom makes her a present of some dollars, called hällân l-hạgậm, "the loosening of the belt," whereas in the opposite case he flogs and abuses her by calling her a hajjâla, "widow" or "divorced wife." The absence of blood may indeed lead to an annulment of the marriage contract, a restoration of the presents given by the bridegroom, and an additional flogging of the bride by her parents; but it may also happen that the bridegroom after the thrashing forgives her for her lost virtue and marries her all the same. If the bride is found to be a virgin, the bridegroom pulls up the backs of his slippers and wears them in that fashion for seven days, whilst the bride wears her slippers with pulled-up backs only till she has arrived at her new home. The blood-stained garment is taken round the village by the women, and is also exhibited in the bridegroom's village if near. All the people come and look at it and rub their eyes with the red stains; for this blood, which is called s-sbah, "the morning," is supposed to contain baraka and be wholesome for the eyes. The people bless the bride, saying :-Flânna llah yớrdị ailẹha, jâbĕt s-șbaḥ měziânn, "May God be gracious to so-and-so, she has brought a nice morning." But whether the bride was found a virgin or not, the bridegroom does not remain 
long with her in the tent or straw-hut, but goes home for the night.

The custom of painting the bride with henna is extremely prevalent in the Muhammedan world, even more so than the application of henna to the bridegroom $;^{1}$ and there can be no doubt that it is universal in Morocco. Its real object is to purify her and protect her from evil influences; for the bride, who like the bridegroom is regarded as holy, is likewise held to be very susceptible to harmful supernatural influences, either magical forces or evil spirits. There is a jẹ̆nn called hătțaf lä-'rais, whose speciality is to steal brides. ${ }^{2}$

As we have seen, the henna is applied not only to the bride's hands and feet, but sometimes also to her legs below the knees, her arms, face, and hair. The painting is performed either by her maiden friends or

1 Gaudefroy-Demombynes, Les Cérémonies du mariage chez les indigènes del'Algérie (Paris, 1901), pp. 17, 26; Robert, Voyage à travers l'Algérie (Paris, s.a.), p. 226 ; de Calassanti-Motylinski, Le Djebel Nefousa (Paris, 1899), p. Ix2; Biarnay, Etude sur le dialecte berbère de Ouargla (Paris, 1908), p. 458. Mrs. Todd, Tripoli the Mysterious (London, 1912), p. 97. Lane, Manners and Customs of the Modern Egyptians (London, 1896), p. 178 sq.; Idem, Arabian Society in the Middle Ages (London, 1883), p. 234 (Cairo); Klunzinger, Upper Egypt (London, 1878), p. 198. Snouck Hurgronje, Mekka, ii. (Haag, 1889), p. 165. D'Arvieux, Travels in Arabia the Desart (London, 1718), p. 231. Wortabet, Syria and the Syrians, i. (London, 1856), p. 286. Klein, 'Mittheilungen über Leben, Sitten und Gebräuche der Fellachen in Palästina,' in Zeitschrift des Deutschen Palästina-Vereins, vi. (1883), p. 95 ; Van-Lennep, Bible Lands (London, 1875), p. 547 (Palestine). Löbel, Hochzeitsbräuche in der Tilirkei (Amsterdam, 1897), p. 46 (Baghdad). Meer Hassan Ali, Observations on the Mussulmauns of India, i. (London, 1832), p. 384 . Skeat, Malay Magic (London, 1900), p. 375 sqq. Tremearne, Hausa Superstitions and Customs (London, 1913), pp. 85,87 sq. Among the Hausas "the henna is doubtless a Mohammedan introduction; formerly it would seem that oil or grease was used instead."

2 For a similar belief in Algeria, see Gaudefroy-Demombynes, op. cit. p. 49 ; $I d e m$, in Revue des traditions populaires, xxii. (1907), p. 54 . 
by one or the other of the following persons: her mother, aunt, or sister, a first-born girl of her family bearing the name of the Prophet's daughter Fațima, the bridegroom's married sister, a married woman who must have been married to a bachelor and not been married more than once, or a female professional. The bride is painted privately or publicly, sometimes on two festive occasions, but in most tribes in the presence of women and children only. Henna is, moreover, used by her girl-friends ${ }^{1}$ and even the married women present, and they may also, like the bride herself, ${ }^{2}$ be painted with other purifying or protective stuffs, such as antimony, walnut bark, and saffron.

The bride is further purified by bathing or waterpouring, ${ }^{3}$ to which much importance is attached by

I Cf. Biarnay, op. cit. p. $45^{8}$ (Ouargla); Lane, Modern Egyptians, p. I79.

2 Cf. Lane, Arabian Society, p. 234 (Cairo); D'Arvieux, op. cit. p. 231 ; Wortabet, op. cit. i. 286 (Syria); Klein, loc. cit. p. 95 (Palestine); Meer Hassan Ali, op. cit. i. 384 (Muhammedans of India); Skeat, op. cit. p. 375 sqq. (Muhammedans of the Malay Peninsuia). Arabic writers say that the bride should brighten her face, put on the best of her apparel, adorn her eyes with antimony, and stain her hands and feet with henna (Lane, Arabian Society, p. 234 sq.).

3 Cf. Gaudefroy-Demombynes, op. cit. p. 44, Villot, Mours, coutumes et institutions des indigènes de l'Algérie (Alger, 1888), p. 107, and Robert, op. cit. p. 226 (Algeria); Menouillard, 'Un Mariage dans le Sud Tunisien (Matmata),' in Revue Tunisienne, ix. (I902), p. 372 ; Lane, Modern Egyptians, p. 177 sq., Idem, Arabian Society, p. 233 sq., and Klunzinger, op. cit. p. 197 (Egypt); D'Arvieux, op. cit. p. 231 ; Guys, Un Dervich algérien en Syrie (Paris, I 854), p. 200, and Wortabet, op. cit. i. 286 (Syria); Klein, loc. cit. p. 95, and Van-Lennep, op. cit. p. 547 (Palestine); Löbel, op. cit. p. 24 sq. (Muhammedans of Turkey); Jaffur Shurreef, Qanoon-e-islam (Madras, 1863), p. 89 , and Meer Hassan Ali, op. cit. i. 384 (Muhammedans of India). According to Arabic writers, "it is a sunneh ordinance that the bride wash her feet in a clean vessel, and sprinkle the water in the corners of the chamber, that a blessing may result from this" (Lane, Arabian Society, p. 234). Among the Bedouins of Sinai the girl is on her betrothal sprinkled with the blood of a sheep sacrificed for the occasion, and remains for three days in the tent erected for her in front of her father's habitation; at the end of this period "she is conducted by a procession of women to 'a spring of living water' (that is, a perennial spring), and after performing her ablutions is led home to the house of her husband" (Palmer, The 
townsfolk. Her grinding of wheat over her bare thigh may be a ceremony of purification, or, perhaps, a fertility charm. ${ }^{1}$ The taps which her brother gives her with his slipper may have the same object as the beating of the bridegroom, that is, to drive away evil influences, and it is not impossible that a similar idea really underlies the bridegroom's gentle smack, though it is now said to have the purpose of making the bride afraid of him. To the same class of ceremonies, as we have seen, belong the dancing with the henna bowl ${ }^{2}$ and the breaking of it, which occur at the feasts of both parties, although at the bride's feast the bowl is not generally allowed to drop and break. At the henna-ceremony of the latter we also meet with burning candles, a bottle of water, salt, steel-in the shape of a needle,-the crossing of swords, ${ }^{3}$ loud music and singing, the quivering noise of women, and occasionally powder-play; and in one case a silver coin is said to be tied round her

Desert of the Exodus [Cambridge, 1871], p. 90). In his description of the marriage customs of the Jews, particularly those of Morocco, Addison (The Present State of the Fews [London, 1676], p. 46) says that the bride bathes daily for eight days before the wedding. Among the ancient and modern Hindus, as also among other IndoEuropean peoples, it has been, or still is, considered an essential preparation for a wedding that the bride should have a bath (Colebrooke, Miscellaneous Essays, i. [London, I837], p. 208; Haas, 'Die Heirathsgebräuche der alten Inder,' in Weber's Indische Studien, v. [Berlin, 1862], pp. 198, 278, 294 sqq., 304, 381, 382, 4 II ; Winternitz, 'Das altindische Hochzeitsrituell,' in Denkschriften der Kaiserl. Akademie der Wissenschaften, Philos.-histor. Classe, xl. [Wien, 1892], p. 43 sq9.).

1 Cf. infra, p. 195 sq. n.

2 In Syria, after being painted with henna, the bride, supported by two of her relatives, makes as if to dance; after which "the ladies take their turn at dancing" (Wortabet, op. cit. i. 286).

3 In other Muhammedan countries there are in the bridal procession two men with drawn swords escorting the bride. See Mornand, La Vie arabe (Paris, 1856), p. 58 (Constantine, in Algeria); Van-Lennep, Bible Lands (London, 1875), p. $55^{1}$ (Palestine); Lynch, Narrative of the United States' Expedition to the River Fordan and the Dead Sea (London, I850), P. 448 (Jaffa). 
wrist as a protection against $j n \bar{u} n$. The custom of her imitating the appearance of a man by wearing her lizar thrown over her left shoulder and a dagger slung over her right, or by having designs resembling whiskers painted on her face, has already been discussed in a previous chapter. ${ }^{1}$ She has her face and eyes covered, ${ }^{2}$ both as a shelter for herself and because her own gaze is considered dangerous. ${ }^{3}$ She is confined in her house for two or three days before the wedding. She has the backs of her slippers pulled up; and sometimes she is carried to and from the place where she is painted with henna. The carrying of the bride, however, may not only be meant as a prophylactic, but may be a ceremonial expression of her bashfulness or pretended reluctance to marrying, as is the case with the crying which is expected from her during the preparations for her departure. ${ }^{4}$

1 Supra, p. 27.

2 The veiling of the bride is not only universal in the Muhammedan world but has also been common in Europe (v. Schroeder, Die Hochaeitsbräuche der Esten und einiger andrer finnisch-ugrischer Völkerschaften, in Vergleichung mit denen der indogermanischen Volker [Berlin, 1888], p. 72 sq9.; Samter, Familienfeste der Griechen und Römer [Berlin, I90I], p. 47 sq9.). The importance which the ancient Romans attached to this custom appears from the ordinary use of the word nubere or obnubere to denote a woman's marrying. The veiling of the bride is referred to in Genesis, xxiv. 65.

3 Among the Touareg of the Ahaggar the bride is not allowed to look at the fantasia of the horsemen, because, "si, par malheur, elle regardait un des cavaliers, celui-ci tomberait et un accident se produirait" (Benhazera, Six mois chez los Touareg du Ahaggar [Alger, I908], p. I5).

${ }^{4}$ Cf. Burckhardt, Notes on the Bedouins and Wahábys (London, 1830), p. 151. For the customary weeping and crying of the bride among Indo-European peoples, see Haas, loc. cit. p. 327 sq.; Winternitz, loc. cit. p. 42 sq. ; v. Schroeder, op. cit. p. 86 sq9.; Rossbach, Untersuchungen über die römische Ehe (Stuttgart, 1853), p. 329. There is no ground for Winternitz' suggestion that this custom is a survival of an earlier marriage by capture ( $c f$. Westermarck, The History of Human Marriage [London, 1894], p. 388). Among some South Arabian Bedouins the bridegroom and his bachelor friends have to search for the bride when they come to fetch her; 
At the same time there are also connected with the bride's henna-ceremony things and actions which are intended to have a favourable influence on her future. There is the giving of grâma, but not so frequently nor on so large a scale as at the bridegroom's feast. ${ }^{1}$ Besides the coins there are other objects of silver, and eggs and milk, to make her life bright and happy, and the eating of dates to make her prosperous. There are various magical practices intended to make the husband obedient to his wife or to make her dear to him or his family. And there are, finally, certain ceremonies performed with a view either to facilitating the first intercourse between the young couple or to promoting fecundity.

and when they find the cavern into which she has fled, they are received by her girl-companions with a shower of stones (v. Wrede, Reise in Hadhramaut [Braunschweig, 1870 ], p. 262 sq.). Among the Bedouins of Sinai, should the girl get an inkling of her betrothal, "it is considered etiquette for her to make a show of escaping to the mountains"; nay, in one tribe she actually "runs off to hide in the mountains for three days, instead of remaining in a tent near her father" (Palmer, op. cit. p. 90 sq.; $c f$. Burckhardt, op. cit. p. 153). "Chez les Beni Saber, la femme s'enfuit . . . le premier soir du mariage" (Jaussen, Coutumes des Arabes au pays de Moab [Paris, 1908], p. 55). Among the Nestorians of Syria the bride remains in a corner of the apartment, or the church, during the greater part of the nuptial ceremony; "when they have reached a part where hands are to be joined, several women catch hold of the bride, veiled as she is, and pull her by main strength half across the room towards her intended husband, who is at first equally resolute in his modest reluctance, but finally yields and advances towards the bride. A smart struggle ensues in his effort to secure her hand; but he at length succeeds" (Van-Lennep, op. cit. p. 552 sq.). Cf. v. Schroeder, op. cit. ch. xxiii.: "Das Entlaufen oder Entfliehen der Braut,' p. 141 sqq.

I In Egypt, " a large quantity of henna having been prepared, mixed into a paste, the bride takes a lump of it in her hand, and receives contributions (called 'nukoot') from her guests. Each of them sticks a coin (usually of gold) in the henna which she holds upon her hand; and when the lump is closely stuck with these coins, she scrapes it off her hand upon the edge of a basin of water" (Lane, Modern Egyptians, p. 178). At Mecca the sticking of coins to the forehead of the bride is called nasssah (Snouck Hurgronje, op. cit. ii. 181). 


\section{CHAPTER V}

\section{THE FETCHING OF THE BRIDE}

$\mathrm{O}_{\mathrm{N}}$ the day when the wedding proper begins the bride is taken to her new home. The fetching of her is connected with various ceremonies, which will be now described.

At Fez, when the bridegroom has been shaved, the men of his family, with the exception of his father, together with some female relatives and a crowd of boys, go to fetch the bride. If there is living in her house any unmarried woman or girl, the women say to the bride when she leaves, Furr réjlek, "Drag your foot," so that the unmarried one shall get a husband. The bride is accompanied not only by the bridegroom's party, but also by some men of her family, including her brothers (but not her father), a large number of boys, the ngâgef, and some-perhaps six or eight-women relatives, who are dressed like herself, so that no one can distinguish between them; this is to protect her from magic and the evil eye. The men and boys of the bridegroom's party head the procession, behind them walk the women, including the bride, and last 
come her male relatives, both men and boys. The ngâgef and boys carry candles in their hands. When they walk along the streets the boys of the bridegroom's party sing :

\section{'Abbâha abbâha u lláh ma hallaha,}

He (that is, the bridegroom) took her, he took her, and God did not leave her behind.

The boys of the bride's party again sing :

'Abbât s'u abbầtsu, luwwâts u fă ksâts'u,

She took him she took him, she wrapped him up in his ksa. ${ }^{1}$

When the procession comes to running water, one of the women places herself between the bride and the water and throws salt into it before she passes, as a protection against $j n \bar{u} n$; and the crossing of any open bridge from which water can be seen is carefully avoided.

If the bridegroom is a shereef or belongs to one of the old Arab families of Fez, the bride is brought to his house in a box with a pointed roof (like that of many a saint's tomb), nicely draped, and decorated with pearl bands. This box, which is called gúbba, is pro-

I Mr. Meakin (The Moors [London, 1902], p. 51) gives the following description of the ksa:- "Its cream-white, gauze-like texture surmounts the turban and shields the sides of the head from sun and wind, this ample head-piece being perhaps the most effective part of it all : other folds form abundant skirts and liberal sleeves, while the whole is held in place by a silk-striped, long-fringed end which crosses the breast and hangs gracefully down the back. It is surely the survival or descendant of the famous Roman toga. When taken off, this costume, complete in itself, is found to be but a plain piece of hand-woven woollen material, about six and a half yards by one and three-quarters, with a fringe at each end, and a few silk stripes, also white, at one end." The ksā is often called hâyệk (see supra, p. 96 n.). On the ksā, see also Dozy, Dictionnaire détaillé des noms des vêtements chẽ les Arabes (Amsterdam, 1845), p. 383 sqq. ; Bel, 'La djâzya,' in Fournal Asiatique, ser. ix. vol. xx. (1902), p. 210 sq.; Doutté, Merrâkech (Paris, 2905), p. 249 sqq. 
cured by so-called shhâfa, that is, men whose principal occupation is to carry the dead to the grave, and they also carry the box with the bride to her new home. The bridal box is mentioned by Leo Africanus in his description of $\mathrm{Fez}$, dating from the early part of the sixteenth century. He writes as follows :

"The bridegroom being ready to carry home his bride, causes her to be placed in a wooden cage or cabinet eight-square covered with silk, in which she is carried by porters, her parents and kinsfolk following, with a great noise of trumpets, pipes, and drums, and with a number of torches; the bridegroom's kinsmen go before with torches, and the bride's kinsfolk follow after : and so they go unto the great market place, and having passed by the temple, the bridegroom takes his leave of his father-in-law and the rest, hying him home with all speed, and in his chamber expecting the presence of his spouse." I

At Tangier the bride is transported to the bridegroom's house in a box called 'ammarrîya, ${ }^{2}$ on the back

I Leo Africanus, The History and Description of Africa, trans. by Pory, ii. (London, I 896$)$, p. $45^{\circ}$.

2 The Shareefa of Wazan (My Life Story [London, I9 I 1], p. 13 1 sq.) gives the following description of an "ammāritya:- " 1 t is of plain wood, more like a huge meat-safe, with a conical roof. There is a doorway, naturally, but no door, although the woodwork in front of the entrance is raised some few inches. As a general rule the bridegroom's family undertake to decorate the litter, and before assembled guests, musicians, and cries of "zahrits" the work commences.-Take a large sheet, double it, and drape it round, leaving the entrance a little loose. This is securely pinned over the knobs at each corner, and flounced up to the summit of the cone, where it is fixed with a stout string. This covers the woodwork entirely, and serves as a foundation to secure the rest of the decorations. Next, take a length of gauze or muslin, which must be at least eight yards long by one and a half yards wide, and drape it over the sheet, fixing the gauze with pins, or sometimes with needle and cotton. Next, a belt is arranged on the sloping part of the cone-shaped roof, and the cords used by the women for holding up their voluminous sleeves are disposed. The cone itself is dressed with handkerchiefs like a woman's head-dress, and many have asked me if it was the bride's head emerging from the top of the litter! On very rare occasions pearl necklaces have been added, but few people are inclined to use such a display for fear of accidents of an unpleasant kind." 
of a mule. She is lifted into it by a brother or uncle and is taken a roundabout way to her new home, where the nggâfa lifts her down and puts her on the bed. In the seventeenth century, according to Addison, the "almaria," with the bride in it, was carried through the streets by Christian captives, "and for want of these by Negro's, or by a meaner sort of Whites." 1

In the north of Morocco the ammariya is found in the country as well as in towns. ${ }^{2}$ In the Garbîya it is placed not on a mule but on a stallion, so that the woman shall give birth to male offspring; but formerly a camel was used for the purpose. In Andjra the 'ammarîya is made of oleander branches, which are draped with new cloths of different colours, the oleander being supposed to afford particularly good protection against the evil eye. The box is put on the pack-saddle of a mule, and a boy is shut up inside it, as it is said, to keep it steady; or an unmarried youth may take his place so as to get married soon. It is then transported to the bride's house in a long procession of men, women, and children. A brother of the bridegroom leads the mule; but the bridegroom himself

1 Addison, West Barbary (Oxford, 1671), p. 184.

2 See also Salmon, 'Une Tribu marocaine,' in Archives marocaines, i. (1904), p. 209 sq. (Faḅs); Michaux-Bellaire, 'Quelques tribus de montagnes de la région du Habt,' ibid. xvii. (I91 I), p. I31 sq.; Michaux-Bellaire and Salmon, 'El-Qçar el-Kebir,' ibid. vol. ii. no. ii. (1904), p. 70 sq. In the Hlot and Tliq, according to Messrs. Michaux-Bellaire and Salmon ("Les Tribus arabes de la vallée du Lekkoûs," ibid. vi. (1906), p. 229), the ammäriya is used only by very rich and powerful families, who get one from Alcazar. For the word ammginya, cf. Dozy, Supplément aux dictionnaires arabes, ii. (Leyde, 1881), p. I71 sq.; Marçais, Textes arabes de Tanger (Paris, 1911), p. 391. According to Lerchundi (Vocabulario español-arábigo. del dialecto de Marruecos [Tánger, 1892], p. 74) the bridal box is also called buja. 
and his mother stay at home, whilst his father may go if he likes. The procession is headed by the rma, or huntsmen, who fire off their guns while walking along; after them comes the bridegroom's brother leading the mule ; then two married sisters or other married female relatives of the bridegroom-the so-called haddayin; then eight prominent men of the village, among whom is the $f q \bar{\imath}$, or schoolmaster, riding on mules with the articles belonging to the sdaq; then a large crowd of people; and last of all the musicians (tabbâla and gaiyâda). When they arrive with music and powderplay in the yard of the bride's house, her father welcomes them; they are all served with a meal of kúsksu, and the principal men, who are invited inside the house, are also entertained with tea. They have a friendly conversation with the bride's father, promising him that his daughter will be well treated in her new home. Meanwhile the bride herself is sitting in her room together with her wazâra, very lightly dressed and with her hair loose, and is weeping all the time since the arrival of the procession. A strong woman of her kin lifts her from the bed and carries her on her back into the ammạrîya, which has been placed close to the door and covered with blankets in such a manner as to make it impossible for any outsider to see the bride; it is believed that anybody who should see her would get blind. Her brother receives the hláwa due to him, as has been said before; but even now the procession is not allowed to leave in peace : the married women who remain behind tell the little boys to throw stones at the 
'ammarîya, and then follows a shower of stones thrown by men and boys of the village. Of this custom a twofold explanation was given: it was said to make the husband love his wife and prevent his sending her back to her old home, but I was also told that it would cause her to take her evil with her instead of leaving it behind. The procession is again headed by the huntsmen, who all the way fire off their guns; then comes the mule with the ammariya and the bride, led by the brother who received the money, and guarded on each side by two other brothers or male relatives; then the bride's hadday in, who are two married women of her family, followed by her female relatives or friends with the exception of her mother and unmarried sisters, who remain at home; then two mules out of those which were brought from the bridegroom's place, this time loaded with bread and figs presented by the bride's family to be used as provisions on the way; then the general crowd; and last the musicians playing their drums and oboes. The six other mules, ridden by prominent men of the bridegroom's village, were sent in advance to his house laden with the bride's luggage and accompanied by the bridegroom's haddayzm, whose business is to see that nothing is stolen from them.

If the procession passes a village on its way, a woman comes out and offers the bride some milk, which is supposed to make her a good wife. It is given to one of the hadday ${ }^{2}$, who hands it to the bride inside the box; she drinks a few drops of it and blows on the 
rest so as to impart to it a little of her holiness. The hadddy in and other persons round her then moisten their lips with it, and what is left is taken back to the house, where it is drunk or poured into the churn in order to make the butter plentiful.

Among the Tsal, on the day of the second hennaceremony of the bridegroom, people from his village, including his brother but not his mother, go to fetch the bride, taking with them a mare ridden by the brother. This is done even if the bride is living in the same village; in such a case she leaves her home about sunset, otherwise earlier in the day, according to the distance between the bridegroom's village and her own. She is mounted on the mare by a brother or cousin, and is accompanied by a sister or a daughter of her father's brother, or by a paternal aunt, but not by her mother. She has with her two sacks, one of which is filled with $t^{s} r i d$, that is, very thin large round cakes made of wheaten flour, water, and butter, whilst the other contains raisins; both the $t^{s} r \bar{l} d$ and the raisins are the next morning distributed among the men in the bridegroom's village as z-zérda dyāl l-ărûsa, " the feast of the bride." When she leaves her parents' house her relatives throw stones after her and her party, which is said to relieve her of her bas and make her happy in her marriage. But before this is done it may happen that her father or brother, if displeased with her, flings at her a sooty piece of an old broken earthenware pan, in order that her husband shall soon die and she return 
to her old home. She has on her head a conical hat made of cane, bound round with silk cords, from which are hanging two or three silk kerchiefs to conceal her face. She must not look at anybody; if she did there would be fighting and manslaughter at the wedding that very day. Nor must she turn her head lest her husband should die. If the procession passes a village on its way, women come out and sprinkle milk on the bride so as to make her future white.

In the Hiaina the bride is fetched by a crowd of women and men, including the bridegroom's mother and brothers, but not his father, unless, indeed, something still remains to be settled with the bride's parents. They take with them a saddled mare which is ridden by a little boy, since an empty saddle would be a bad omen. When the women enter the bride's house they sing :

\section{feinnāk á mmì l'ărû̉s, gul linna márhaba,}

We have come to you $\mathrm{O}$ mother of the bride, say to us welcome.

They are sometimes entertained with a meal and sometimes not. A brother of the bridegroom lifts the weeping bride from the door of the house into the saddle. She has her face covered, so that nobody can see it and she can see nobody, and her hair is loose. A little boy rides behind her, not only to keep her in the saddle but in order that she shall give birth to male offspring. The mare is led by the bridegroom's mother, whilst the bride's mother goes behind holding the tail so as to make it impossible for any wicked 
woman to bewitch the bride by pushing her finger into the vulva or anus of the mare. When the bride and her party leave the village, the children and young folk of the place throw stones after them, and are then themselves pelted with stones by the boys in the procession. There is powder-play all the way, and milk may be offered the bride when passing a village. The procession arrives at the bridegroom's place at night, shortly after he has had his hands rubbed with flour, as described before. The men and women guests, who assemble there about midday, have been entertained with tea, țấam (š̌ksu) and meat, and bread and meat; and there has been powder-play on horseback as well as music

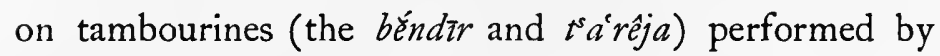
women and men. This is the wedding proper, l-örs.

Among the Arabs of the Ulâd Bu-Ǎzîz the 'örs (or 'ärs) takes place in the bridegroom's tent on the evening following l-bătța. The men of his village are practising powder-play, and both they and the other villagers are entertained with séksu and the meat of a sheep or bullock which has been slaughtered the same afternoon. After this meal a crowd of men, women, and children go in a big procession, some riding but most of them on foot, to fetch the bride from her home, taking with them a camel, on which one or two children ride. The men are firing off their guns, and the women are making their usual quivering noise. When they arrive at the bride's tent they are welcomed by her family and entertained in the open air with séksu and 
meat of the sheep which was slaughtered the day before. The women then enter the tent where the bride is waiting. Her hair is combed and perfumed; she and her mother weep, and the other women are making a quivering noise. Dressed in a cloak (sélhäm) belonging to some man of her family, with her head and face well covered by the hood, she is lifted out of the tent by her brother or, if she has no grown-up brother, by her cousin. She is then put down in a standing position outside the entrance, where a brother or friend of the bridegroom gives her a silver coin, which she hands over to her mother ; the object of this is to make her "white" like the silver, that is, a good wife. Her brother or cousin lifts her on to the camel, which besides is loaded with her clothes, some chickens, salt butter, and flour. Custom requires that she should weep on this occasion, otherwise it is said that she does not care for her parents. When she is riding, a boy of her family is sitting in front of her and another behind. The camel is surrounded by her relatives only, while the bridegroom's party walk at some distance from it. The procession advances amidst the quivering noise of women and powder-play on the part of the men; and if they pass a village the inhabitants offer the bride milk, fresh or sour, and a silver coin.

From Arabic-speaking tribes we shall pass to tribes belonging to the various Berber groups. Among the Brâber of the Ait Sádden, on the wedding day (ass $n$-tmăgra), a large crowd of people from the bridegroom's 
village go to fetch the bride. If she is living far away, the procession starts in the morning, otherwise later in the day; and if she is from the bridegroom's own village, she is only fetched about an hour before sunset; it is considered a good omen for the people of her new home if she arrives there at the same time as the flocks and herds return from the pastures. The bridegroom's mother, sisters, and other female relatives must be in the procession, and if the bride lives in the neighbourhood even the bridegroom himself may go, though well covered up. Indeed, it may happen that hardly any other living beings but the dogs remain behind. The people take with them a mare, which is ridden by a little brother or male cousin of the bridegroom; and the boy holds in his hand a flag, which is afterwards given to the bride. The mare is led by the bridegroom's mother, while his sister or sisters keep hold of the tail, and the two imsnein'walk on either side with their hands on the stirrups. The beast on whose back the bride is going to be carried away may not be a horse or mule, but must be a mare, which is a fruitful animal, and the person who rides it must be a little boy.

When the procession has reached its destination, the bridegroom's mother and sisters take in the bride's clothes, which they have brought with them ; and after she has been dressed in them she is painted with henna, as said before. Her little brother or a paternal cousin then removes his taqbbut (jẹllạ b) and places it in front of her, or, if he wears an áslhạm (sélhäm) or âbạn (hâyyệk), spreads a part of it on the ground. As a present to 
him she puts on it the money called táydat, which was sent by the bridegroom on a previous occasion. She takes a step or two on the cloak or âban in front of her, one of the imsnein lifts her up on the mare which is standing close by, and the other amsnäi places behind her a little brother or paternal cousin of hers, who is the same as the one just mentioned in case he is a young boy. Sitting behind the saddle the boy keeps his arms round her waist; the bridegroom's mother again leads the mare, his sister or sisters keep hold of the tail, and the two imsnein walk, as before, on either side with their hands on the stirrups. Any suspicious person, such as a scribe or an old woman, that comes near the mare is driven away by the imsnein and the bridegroom's sisters, who are concerned with protecting the bride from witchcraft (sshiör or ihärgy än, the latter being the name given to witchcraft practised by women). In the procession there are also people from the bride's village, including her mother, who carries with her the so-called l'âda (literally, "custom")-dried fruit put into an ahred (the Arabic mézwud) or tahrett (diminutive of ahred), as also a small box (ásfad) containing two or three looking-glasses, antimony, walnut root or bark, and hárrăqsus, a sweet stuff eaten to prevent hoarseness, which is subsequently given by the bride to the bachelors. The bride's father, on the other hand, cannot go with her, nor her grown-up brothers, who must avoid their sister during the wedding period. When they have proceeded a few steps from the house, the boys and bachelors of the village begin to throw 
stones at the bride and the people round her, so that they shall carry away with them all the evil (ainndihhan) of the village. A similar ceremony, though on a smaller scale, takes place if the bride and bridegroom are from the same village; and in either case the stone-throwing is returned by the people in the procession. I was told that the object of this ceremony could not be to prevent the bride from coming back either on account of divorce or of her husband's death, since the young men do not like the girls of their village to be taken away from them, and are only too happy if a woman who has been married to a man of another village soon returns. The bride is holding in her hand the white flag brought by the boy who rode the mare. The men of the bridegroom's party discharge gunpowder at it to burn it to ashes, and try to break the cane to which it is fastened, by loading their guns with bent twigs. The bride makes fruitless attempts to prevent the destruction of the flag and cane by waving them round. When successful in their efforts the men laughingly say, "Now she is no longer a virgin," or, "This evening she will be broken like the cane."

When the procession amidst volleys of gunpowder passes a village, the women come out and sprinkle the bride and the people accompanying her with milk or, if they have no milk, with a mixture of henna and water. This was represented to me as a safeguard against evils which would otherwise result from the discharge of gunpowder-it prevents enemies coming to attack the village with their guns; for the milk or henna 
brings security and peace. It is to be noticed that the same ceremony took place when the bridegroom's party went to fetch the bride, on that occasion also amidst volleys of gunpowder, and that among the Ait Sádden no milk is offered to the bride to drink.

Among the Ait Yúsi a brother or some other male relative of the bridegroom walks in the centre of the procession of people who go to fetch the bride. He carries on his back a variety of goods: a tamĕnșürt, a lizar, a belt (lhăzám), an ordinary head-kerchief (ahěnbus) and another one made of silk (țdsěbnțt), a pair of slippers (rréhit (timrit), as also some henna (lhd̈nna), saffron (zziafran), and cloves (nnwar) —all presents sent by the bridegroom to his bride. There is music, singing, and dancing, but no powder-play during the march. If the bride's village is far away, the people take with them the mare on which the bride is going to ride ; otherwise it is sent the following day. Neither the father nor, in some places, any grown-up brother of the bridegroom must go with the procession, since it would be regarded as shameful if they saw his bride; but his mother may go if she is not too busy.

The procession arrives at the bride's home in the evening, and both men and women are entertained there with tea and aftäl (sěksu) and meat. About midnight the bride is painted with henna, and the next morning she is dressed in her bridal costume. She then goes to the entrance of the tent or threshold of 
the house, where a brother or, if she has none, a paternal cousin is standing with a part of his âban spread on the ground. She takes three steps on it and lets a silver coin, a quarter or half a dollar, drop down as a present to the brother or cousin, to whom it is supposed to bring good luck on account of the baraka of the bride. With her face covered she is then lifted into the saddle (tariht) by one or two of the imsnein appointed by the bridegroom from among his relatives or friends (he may appoint from two to four), and behind her is placed a little boy who puts his arms round her waist. The mare is led by a woman of the bridegroom's family, whilst women of the bride's family walk behind keeping hold of the tail. The sexual organ of the mare is covered with a kerchief for the purpose of preventing any man or woman from pushing a finger into it, as it is believed that this would deprive the bride of her virginity, and thereby perhaps lead to a speedy divorce. The bride's mother may or may not accompany her daughter, but it is not the custom for her to take dried fruit with her if she goes. There is music, singing, dancing, and powder-play as the procession moves along. The bride holds in front of her a cane, with or without a flag, which she waves to and fro in order to save it from being broken by the men firing at it. They want to blow it to pieces so that the bridegroom shall be able to break the hymen of his bride that night, but out of bashfulness she makes some efforts to prevent it.

There is no general stone-throwing at the departure of the bride from her old home, but it may happen 
that some person who is angry with her throws after her seven stones in succession, saying, "May God prevent you from coming back." When they pass a village some woman comes out and sprinkles the bride and her company with milk to give them good luck; but if the year is dry and rain is wanted, the bride is sprinkled with water instead of milk. The imsnein capture sheep from the flocks seen on the road, though not more than one animal from each village. The shepherds try to keep the sheep out of the way; but when one is caught it becomes the property of the bride, who decides whether it shall be slaughtered or not, and no compensation can be claimed by its owner.

Among the Ait Nder the bridegroom's mother takes new clothes to the bride, either carrying them on her back or riding with them on a mule, when she goes with the others to fetch the bride. The father may also go if he likes, but more often, it seems, he remains at home. For the same reason as in other tribes the animal on which the bride is brought to her new home must be a mare, and when it is taken to her place it is ridden by somebody, as here also an empty saddle would be looked upon as a bad omen. When the procession arrives at the bride's village it is met with a shower of stones thrown by men and women, as if it were a troop of enemies ; but this is only a joke, which soon gives way to a friendly reception. The value of the clothes brought by the bridegroom's mother is written down by two scribes, as it is counted in the 
ssclaq; and a meal of affäl (séksu) is served to them and two or three other persons of importance. The bride is lifted into the saddle by a man belonging to the bridegroom's family, and if she is afraid of falling down a boy is placed behind her. She is well covered up; the Ait Nderr, like the Tsal, believe that there would be fighting the same evening if she looked at anybody on the way. If the bridegroom's village is at some distance the bride's mother accompanies her there, taking with her butter, flour, bread, dried fruit, salt, and sugar ; whereas, if the bridegroom lives in a village close by or in the same village, she goes there early next morning. Other women also, but no men, of the bride's family go with the procession. In front of the bride, over the mare's head, the men of the bridegroom's party are firing off their guns at short intervals as they proceed.

Among the Ait Warain the people who go to fetch the bride include the bridegroom's mother and brothers, but not his father. They bring with them nothing else but a mule with an empty pack-saddle (lbérda't) and a saddle-cloth (táhläst). On their arrival they are entertained with tahrirt left from the previous evening. The bridegroom's brother lifts the bride from the doorway of the house and puts her on the mule, which is then led by her young sister or some other girl of her family. The mother always goes with her daughter to the bridegroom's house, but returns at once escorted by two or three men; it is believed that if she should stay there she would take away her daughter's 
beauty. The procession further includes many other persons from the bride's village, both women and men, among whom may be her brothers but not her father. They take with them a mat (ájertil), a táhläst, some five or six lemdûd of roasted barley (tûrift), together with raisins, almonds, pomegranates, figs, and honey, as also a skin-sack (tamzitt) filled with figs, raisins, almonds, and walnuts. All this is put on the mule on which the bride is riding, seated on a new taberdót or mantle, which has been placed over the saddlecloth. In front of her men with guns are discharging volleys of gunpowder, while the female members of the procession are playing the tambourine (allun). When they pass a village the women come out making a quivering noise, and offer the bride some milk in a bowl, which she takes in both hands and sips from, the women themselves drinking what is left.

Among the At Ubáhți the wedding is celebrated in the bridegroom's home with much eating, powder-play, and timusit, or quivering noise of women. Among the people who go to fetch the bride there are all the bachelors of the village except the $a$ uzir, and many other men and women besides; but the parents of the bridegroom stay at home. They start early enough in the day for the bride to arrive at the village in the afternoon, at the time for the 'âsar prayer, and they take with them a mare or a mule, which must be ridden by somebody so as not to go with an empty saddle. From the entrance of the tent the bride is lifted on to the animal 
by one of the islän; and she is accompanied on her journey by her mother, who takes with her salt butter, flour, raisins, figs, and dates for the meal she is going to serve the following day at the bridegroom's place.

Among the Ait Wäryâgäl four or five married men from among the bridegroom's relatives, but not his father, go to fetch the bride from her home. After they have been entertained with food she is carried out by her brother or, if she has no grown-up brother, by her paternal or maternal uncle, and is placed on a mule which is led by a boy-a brother or cousin. She is accompanied by men, women, and children from her village, but not by her parents, who remain at home. The women sing and make a quivering noise, and the men fire off their guns. When they pass a village milk is brought to the bride, who dips the little finger of her right hand into it ; the milk is afterwards mixed with other milk, so as to give it the benefit of the bride's baraka and thus serve as a charm against witchcraft, which is much feared. This day is called dámăgra, "wedding."

Among the Shlöh of Aglu the bride is fetched by a crowd of people, including musicians with drums and women who make a quivering noise. They take with them a camel bearing a so-called aragn, that is a frame made of four wooden posts with a strong network stretched between them, as also a lizar for the bride and several pairs of slippers for the men and women of 
her family. The bride, with her face covered, is carried out of her room by a brother or some other male relative and placed on the arign on the back of the camel. Four other girls seat themselves there, two on either side of her. ${ }^{1}$ The camel is led by a black man, on both sides of it walk two other men, and in front of it goes the luzîra, carrying on her head a flower-pot with a sweet-scented plant called lhăbáq. The women of the procession sing :

Tigimmi lájwad as äittáwi ùgaras, ig̉ tullan läjwad ilint tiğausîwin,

A house of good people whereto the road will take her; if there are good people, there are all kinds of good things.

Among the Ait Táměldu the bride is fetched by a large number of men with guns and a few women of the bridegroom's family, but his parents are not among them. On their arrival at the bride's home they are entertained with a meal of bread and meat, or sěksu with meat. Well covered up, the bride walks out into the yard (tágrurt). Her brother, uncle, or cousin lifts her on to the back of the mare or she-mule which the bridegroom's party brought with them, mounts the animal himself, and rides seated in front of her. They are accompanied by a large number of women and children and a few men from the bride's village, but not by her parents. Her mother goes to the bridegroom's house three days afterwards, in the evening, and her father, in the company of a few friends, only

1 At country weddings in Egypt, when the bride is conveyed to the bridegroom's dwelling seated on a camel, "sometimes four or five women or girls sit with her on the same camel, one on either side of her, and two or three others behind " (Lane, Modern Egyptians [London, 1896], p. 184). 
when the wedding is over, taking with him the liqqâma. Here, also, it is the custom that, if the procession passes a village on its way, women come out and offer the bride milk to drink for good luck.

Among the Igliwa the bride is taken from her home on a mule, to which she is carried by a brother or cousin, or other strong male relative, unless she is so big that she has to walk there herself. Her face is well covered up, and behind her sits a boy called múmmu $n$-islan. The mule is led by one of her male relatives, whilst the woman who painted her with henna keeps hold of its tail with a cloth so as not to touch the hair with her bare hand; I was told that this custom has a magical foundation, though my informant was unable to explain it. In front of the bride go men discharging volleys of gunpowder, and after her follow women and children. The procession first goes to a river, which the bride crosses on her mule three times to and fro, while the others are waiting on the bank.

At Amzmüz the bride is taken to her new home on a saddled mare. When she is about to mount it she first walks on a blanket which has been spread over the floor and threshold of her room, in order to prevent her treading on the ground, and is then carried to the mare by a strong man, who may or may not belong to her family. Her young brother or, if she has none, some other boy from among her relatives rides behind her. If she has to cross a river on her way, her family claim money from the bridegroom's family because they are taking her so far away; and. if the procession passes a 
shrine, the bride on the mare is taken three times round it and fâtha is made.

To sum up:-The bride is fetched by relatives of the bridegroom or by other people from his village as well, generally persons of both sexes, though in one case she is fetched by a few men only. The bridegroom himself almost invariably stays at home, ${ }^{1}$ and so does, as a rule, his father, and in several tribes his mother, whereas in others the latter frequently or always goes with the procession. In one instance not only the bridegroom's father but also his grown-up brothers are prevented by custom from fetching the bride. The party are generally well received by the bride's family, and in many cases entertained with a meal; but in one tribe stones are thrown at them when they arrive, probably as a sham opposition to their taking away the girl, ${ }^{2}$ but perhaps also with a view to preventing their bringing evil with them. Sometimes the bride's brother does not allow them to take away his sister until they have paid him some money, and a similar claim may be made by the bride's family on the road.

In country places the bride is carried to her new home on the back of an animal, on to which she is lifted

I In some parts of the East the bridegroom goes himself to fetch the bride. See Van-Lennep, Bible Lands (London, 1875), p. 551 sq. (Palestine); Lynch, Narrative of the United States' Expedition to the River Fordan and the Dead Sea (London, 1850), p. 448 (Jaffa); v. Wrede, Reise in Hadhramaut (Braunschweig, 1870), p. 262 sq. The same, as we have seen, was the case at Fez in the days of Leo Africanus.

2 In Palestine, when the bridegroom and his friends come to fetch the bride, "a show of resistance, and sometimes quite a struggle, ensues, when she is surrounded by the bridegroom's friends, taken possession of, and borne away" (Van-Lennep, op. cit. p. 552). 
in some tribes by her brother, male cousin, or uncle, or 'a strong woman of her kin, but in others by a man belonging to the bridegroom's family or some bachelor friend of his. The animal is sometimes led by a relative of the bride, such as her brother or unmarried sister, sometimes by a woman of the bridegroom's family, especially his mother, and in one instance by a black man. The bride is often accompanied by her mother, whereas her father always, and in some tribes her mother also, stay at home. The same may even be the case with her grown-up brothers; and in one of the tribes no men at all from her village go with her.

Various precautions are taken to protect her against jnün, the evil eye, or other harmful influences. At Fez she walks in company with some women who are dressed like herself, ${ }^{1}$ and there are burning candles, ${ }^{2}$ salt, and an avoidance of open bridges. ${ }^{3}$ In the

I In Palestine the bridegroom leads by the hand a little boy dressed precisely like himself and called "the mock bridegroom," whe imitates his slightest movements and thus diverts the company (Van-Lennep, op. cit. p. 55 I sq.). In Egypt, when the bridegroom goes to the mosque before meeting the bride, he walks between two friends dressed like himself (Lane, Modern Egyptians, p. I80 sq.). See also supra, p. 26 sq.

2 Among the ancient Jews, when the bridegroom, attended by a company of young men ( $F$ udges, xiv. II), brought home his bride from her father's house, the young female friends of both parties joined the train, lighting their torches (St. Mattherw, xxv. I sqq.). In modern Palestine lanterns and torches are held aloft in front and along the flank of the bridal procession (Van-Lennep, op. cit. p. 551). In ancient Greece and Rome the bride was always taken to her new home with torches (Sticotti, ' Zu griechischen Hochzeitsgebräuchen,' in Festschrift fïr Otto Benndorf [Wien, 1898], p. 182 ; Rossbach, Untersuchungen ïber die römische Ehe [Stuttgart, 1853], p. 335 sqq.; Samter, Geburt, Hochzeit und Tod [Leipzig \& Berlin, I9II], p. 72 sqq.). In Rome one of these torches was made of whitethorn, which was believed to keep away evil influences. Plutarch (2uaestiones Romanae, 2) asks why the Romans "light at nuptials five torches, neither more nor less." This custom might well be imitated by the Moors, who look upon the number five as a charm against the evil eye.

3 In Syria, where the bridal procession also, as at $\mathrm{Fez}$, takes place in the early part of the night, " it is reckoned a very bad omen to pass with the bride before 
country she is dressed in a man's cloak, ${ }^{1}$ guns are repeatedly fired off in front of the animal on which she rides, ${ }^{2}$ and there is loud music ${ }^{3}$ and singing ${ }^{4}$ and the quivering noise of women. ${ }^{5}$ Perhaps the sweet-scented plant which in one place is carried ahead of her is also meant as a charm against evil influences. She is well guarded on her way so that nobody shall be able to harm her by magical tricks; it is for this reason that her mother or other women of her family or the bridegroom's sister or the woman who painted her with henna go behind the animal, keeping hold of its tail. The object of the blanket or garment spread in front

a public bath, and therefore those streets are carefully avoided into which the baths open " (Burckhardt, Arabic Proverbs [London, 1830], p. 115 n.; see also Wortabet, Syria, i. [London, 1856], p. 287).

1 Among the Bedouins of Mount Sinai, if the bride belong to another camp than the bridegroom, one of her relatives throws over her an ' $a b b a$, or man's cloak, before she is placed upon the camel which is going to carry her to her new home; but this is not done if the bride is a widow or divorced wife (Burckhardt, Notes on the Bedouins and Wahábys [London, 1830], pp. 150, 152). Among the peasants ( fellakinn) of Palestine the bride is likewise covered with an 'aba when she is taken to the bridegroom's place (Klein, 'Mittheilungen über Leben, Sitten und Gebräuche der Fellachen in Palästina,' in Zeitschrift des Deutschen Palaestina-Vereins, vi. [1883], p. 98).

2 Cf. Féraud, 'Mœurs et coutumes kabiles,' in Revue africaine, vi. (1862), p. 430 ; Falls, Drei Fahre in der Libyschen Wiiste (Freiburg i. B., 1911), p. 277; Wilson, Peasant Life in the Holy Land (London, 1906), p. 111 ; Jaussen, Coutumes des Arabes au pays de Moab (Paris, 1903), p. 53 ; v. Wrede, op. cit. p. 263 (Haḍramaut).

${ }^{3}$ Cf. Lane, Modern Egyptians, p. 177 sqq.; Wortabet, op. cit. i. 287 (Syria); Van-Lennep, op. cit. p. $55^{1}$ (Palestine); Meer Hassan Ali, Observations on the Mussulmauns of India, i. (London, 1832), p. 388 . According to one tradition the Prophet approved of the beating of tambourines at the celebration of a marriage, but in another tradition this practice is condemned (Lane, Arabian Society in the Middle Ages [London, 1883], p. 233).

4 Cf. Lane, Modern Egyptians, p. I84 (country weddings in Egypt).

5 Cf. Falls, op. cit. p. 277 (Libyan Desert); Lane, Modern Egyptians, p. 178 sq.; Trumbull, Studies in Oriental Social Life (Philadelphia, 1894), p. 49 sq.; Conder, Tent Work in Palestine (London, 1885), p. 323 ; Jaussen, op. cit. p. 53 (Moab); v. Wrede, op. cit. p. 263 (Ḥaḍramaut). 
of her is to prevent her stepping on the ground or the threshold, ${ }^{1}$ and a similar idea no doubt underlies the lifting of the bride. ${ }^{2}$ She has her face well covered or is, in some parts of the country, shut up in a box on the animal's back, ${ }^{3}$ so as to be sheltered from the evil eye, but also because her own look, or even the sight of her, is considered injurious to others. She must not even turn her head, lest her husband should die. This, like many other taboos, seems to have originated in the feeling that a person who is in a dangerous state or is a source of danger to others should do as little as possible and especially avoid doing anything unusual which is not directly intended as a means of warding off the threatening evil; but at the same time the supposed consequence of the bride's breaking the taboo in question may have been suggested by an association between her turning her head and her returning to her old home in the case of the death of her husband. ${ }^{4}$

The dangers to which the bride is exposed and those

I Cf. Emily, the Shareefa of Wazan, op. cit. p. I 36 :- " A bride would be unlucky to put her foot to earth at this period."

${ }^{2}$ Cf. infra, p. 219 sq.

3 At Constantine, in Algeria, the bride is carried on a horse "dans une sorte de cage entourée de gazes épaisses qui la voilaient aux yeux de tous" (Mornand, La Vie arabe [Paris, 1856], p. 58). "In the towns of Palestine and Egypt the bride walks under a canopy, escorted on either side by a man with a drawn sword" (Van-Lennep, op. cit. p. 55I; see also Lynch, Narrative of the United States' Expedition to the River Fordan and the Dead Sea [London, 1850 ], p. 448 [Jaffa]).

4 "In vielen Teilen von Deutschland ist der Glaube verbreitet, dass sich ein Brautpaar auf dem Wege zur Kirche nicht umsehen dürfe. Als Grund hierfür wird angegeben, wer von den beiden sich umsehe, sehe sich nach einem andern Gatten um, werde also bald verwitwet" (Samter, op. cit. p. 147). After mentioning other ideas connected with the prohibition of turning the head, Dr. Samter (ibid. p. 148 sqq:) suggests-I think without sufficient reason-that the original object of this prohibition is to prevent the person to whom it refers from seeing evil spirits which, if looked at, would do mischief. Cf. infra, pp. 231, 250,255 . 
to which she exposes others lead to ceremonies of purification. She is taken three times across a river to and fro, or round a shrine, or she is pelted with stones when she leaves her home-a custom which sometimes is said to rid her of evil, sometimes to cause her to take her evil with her or to remove all the evil from the village, but sometimes also to be a safeguard against divorce. In one instance the sprinkling of milk on the bride and other members of the procession is said to hàve the purpose of averting evil, namely, the fighting which would otherwise result from the discharge of gunpowder; and the same effect is attributed to the sprinkling with water and henna, perhaps because water is "safety" 1 and lhänna phonetically resembles lhäna, "quietness." But more commonly the widespread custom of sprinkling the bride with milk or offering milk to her is looked upon as a means of making her future "white" or lucky, whilst the bride in her turn is supposed to impart to the milk a little of her baraka, which is then utilised in some way or other by those who offered it; and in one case she is said to be sprinkled with water in order that rain shall fall. Yet I am inclined to believe that the idea of protecting the village which the bride passes from misfortune is a more primitive motive for the customs in question than the intention to benefit her or to derive benefits from her baraka. A bridal procession is in Morocco considered to be a cause of ill-luck to anybody who meets it on the road; among the Ait Wäryâgäl it is the

\footnotetext{
1 See supra, p. 136.
} 
custom that if two bridal processions meet, the women of both parties throw stones at each other to drive away the evil, and in Andjra I was told that such a meeting will cause the death of one of the brides. It should also be noticed that milk or water is offered to strangers who come as guests, and, as we shall soon see, to the bride herself when she arrives at the bridegroom's village, side by side with other ceremonies intended to neutralise the evil influences which she might carry with her to her new home. In one tribe the women on the road give to the bride not only milk but a silver coin, and a similar gift has previously been made to her by a brother or friend of the bridegroom in order to make her a good wife; whereas in other tribes the bride presents her brother or cousin who spreads his cloak or hâyẹk on the ground for her with some silver money to give him the benefit of her baraka.

The animal on which the bride rides is not infrequently considered to exercise a magical influence on her. In mountainous districts it is commonly a mule, and among the people of the plains it is often a camel ; but in some tribes near Fez it is invariably a mare on account of its fruitfulness, and in a tribe in Northern Morocco a horse, in order that the bride shall give birth to male offspring. So also the riding of a boy behind her is, sometimes at least, supposed to make her a mother of boys, and it seems that a similar idea underlies the custom which requires that the animal should also be ridden by a little boy when it is taken 
to the bride's place $;^{1}$ anyhow it would be a bad omen if it went there with an empty saddle. There is, finally, a practice prevalent in some Berber tribes which is intended to make it easy for the bridegroom to deprive the bride of her virginity.

1 At Constantine, when the bridal litter is ready, "une mule la conduit chez la femme et y transporte, jusqu'au seuil de sa maison, deux jeunes enfants, garçon et fille, qui attirent sur les époux la faveur divine, et par leur présence leur assurent une postérité " (Gaudefroy-Demombynes, Les Cérémonies du mariage chez les indigènes de l'Algérie [Paris, 1901], p. 37). 


\section{CHAPTER VI}

THE ARRIVAL AND RECEPTION OF THE BRIDE

A $\mathrm{T} F e z$, when the procession arrives at dar l-örs, the men and boys of the bride's party at once go back to her parents' house, from which they came, whilst those of the bridegroom's party proceed to där islän, where he himself is passing the time with his male friends. Only the women of the procession enter dar l-örs, together with the bride, whom they accompany to the door of the nuptial chamber. Her own relatives then return to her old home, while the women of the bridegroom's party go upstairs. The ngâgef, on the other hand, conduct the bride into the nuptial chamber, but remain in its outer compartment when she retires into the däḩû̧́a. After a little while, however, they also enter the däḩứsa, and paint her eyes with antimony, her under-lip with walnut root, and her cheeks with ochre; and on the cheeks they besides make black spots with a pigment called hárqos (prepared from wood ashes, pitch, and spices), ${ }^{1}$ and white spots with a preparation called biad l-ûjäh mixed with water. They then

1 Cf. Meakin, The Moors (London, 1902), p. 70. 
dress her in her bridal costume and take her out into the open space in the middle of the house, where she is carried round on a small table in the same manner as she was the night before in her own home. The ceremonies of the ta $\left.t^{2}\right\} \hat{e} q$ are now repeated in the presence of the women of the bridegroom's family or kin, his mother taking the same part as her mother on the former occasion; but in the singing of the ngâgef the words $h \bar{a}$ $z$-zin $m$-messûs and $h \bar{a}$ hîya märhôna are now omitted, as the bride's face has been painted with cosmetics and she no longer is " pawned." After this performance is over the bride retires to the $d \ddot{a} h \underline{\zeta} \hat{u} \zeta a$ and remains there alone, while the mistress of the ngâgef sits in waiting in the outer compartment, and the other ngâgef are sent by the bridegroom's mother to dar islän with a bundle of new clothes for her son.

In Andjra, when the bride and her company approach the bridegroom's village, the women receive them on the road with their usual quivering noise, and accompany them to the bridegroom's house. On their arrival at the yard his mother offers the bride some milk, a little of which is drunk by her and the hadday 2 , whilst the rest is returned to the mother, who subsequently gives it to her son to partake of just before he enters the room in which he will meet the bride. His mother also receives her daughter-in-law with a raw egg and a cloth filled with little pieces of different kinds of bread, raisins, figs, and walnuts. She dips the egg into the milk and then into some flour, and after pro- 
nouncing a blessing, breaks it by throwing it at the forehead of the mule, " in order that the bride shall be white and red like the egg and bring no evil (bas) with her, but be lucky and a blessing to her husband." She then throws the bread and dried fruit over the ammariya, so that the married couple shall have much to eat. What falls on the ground is picked up and eaten by the children, or is taken by persons who want to impart the bride's baraka to their corn by putting it underneath the heap ( $s a b a$ ) on the threshing-floor. The bride's brother takes her out of the box and puts her on the back of a strong woman belonging to the bridegroom's family, by preference one of his haddáy̆n, who carries her into the room. All this is done in the shelter of blankets, so that nobody else can see the bride, while the assembled women fill the air with their quivering noise. The ammarîya is now undraped, the covering being taken into the room where the bride is sitting. There is much music and powder-play in the yard, and the bridegroom's parents entertain the people with kúsksu and meat. This day is called nhar l-ammạrîya.

Among the Tsal, when the bride arrives at the bridegroom's house, she is received there by his mother

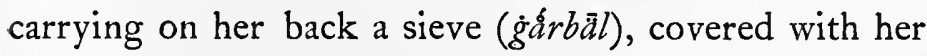
izar; the meaning of this custom is that the young wife shall give birth to children, the sieve representing a baby. ' While the bride is still on the mare, the

1 Among the Ait Wäryâgäl, when a person buys sheep or goats, he puts a sieve at the entrance of the yard and makes the animals step over it so that they 
bridegroom's mother hands to her a tray containing barley with $t^{s} r d$ on the top of it. She takes hold of the tray, throws the trid in all directions over the people, thus conferring on them the benign virtue of her baraka, and then returns the tray with the barley. A brother or cousin of the bridegroom lifts her down from the mare. The bridegroom's mother pours the barley into the bride's izar, which she holds up with her hands, and the bride gives a little of it to the mare to eat, throwing the rest of it in its face, "so that the year shall be blessed and the mare give birth to foals." One of the bachelors mounts the mare and rides on it in order to get married soon. The bridegroom's brother or cousin lifts the bride into the house and puts her down on the nuptial bed, after which she kisses his head. The women, married and unmarried, enter the room and eat a meal there, while the men are having their supper outside in the yard. The bride is all the time sitting on the bed with covered face, partaking of nothing. After the meal the women go away, and she remains alone in the room waiting for her husband.

In the Hiaina the procession goes seven times round the bridegroom's house, after which the mare with the

shall multiply. At Tangier, according to the Shareefa of Wazan (My Life Story [London, 1911], p. 306), "a woman who has had the misfortune to lose all her children except the first one at birth, takes a sieve and rolls it behind this surviving child, whom she burns on the heel with a spoon-handle every time another child is born, so that its brother or sister may live." For the use of a sieve in wedding ceremonies, see Mannhardt, Mythologische Forschungen (Strassburg, 1884), pp. 357, 358, 360, 361, 364 ; Samter, Familienfeste der Griechen und Romer (Berlin, 1910), p. 99. Mannhardt looks upon it as a symbol of fecundity. 
bride is halted at the door. While she is still mounted, the bridegroom's mother offers her a palmetto tray

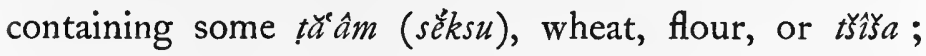
she takes the tray with both hands and throws it with its contents backwards over her head, thereby throwing away the bas. She is then lifted off by the bridegroom's brother and put down at the entrance of the house, from which she walks to her bed. When she is carried from the animal, the men fire off their guns and the women make their quivering noise and sing :

\section{Nezzélha ya ḥmâha, yẹnál bak u bâha,}

Set her down $O$ her brother-in-law, curse your father and her father.

The bride remains in the room in the company of the unmarried girls, who only leave her alone shortly before the entering of the bridegroom.

In the Garbîya the bride on her animal is taken three times round the bridegroom's house or tent from right to left. Outside its entrance a woman belonging to her family throws on the ammariya dried fruit, which the people pick up and eat. The ammariya is then taken down and placed close to the entrance. The bride's brother or cousin lifts her into the house or tent and puts her on the nuptial bed, but he first pricks the bed several times with the point of his dagger as a precaution against witchcraft.

Among the Ulåd Bu-Ăzîz, also, the procession, on the arrival at the bridegroom's tent, goes three times round 
it, after which the camel is made to kneel down before the entrance. The bridegroom's mother or sister hands to the bride some water, which she sprinkles on the people round her in order that there shall be sufficient rain during the year. The mother also offers her some barley or wheat, which she likewise throws on the people so as to make the year good. The bridegroom's brother lifts her from the camel into the tent and puts her down on the bed. Her female friends enter with her and hang up a hâỵ̣̆k as a curtain (hăjba) to prevent others from seeing her. Behind the curtain they all have a meal of sěksu together, while the men and boys who have come from the bride's village are entertained outside the tent.

Meanwhile the bridegroom, dressed in a sêlhäm with the hood drawn over his forehead, is sitting in another place with some friends. A band of scribes come and sit down with them, and they all have a meal. They then stand up and the scribes recite something from the Koran, the bridegroom standing in the centre together with two other men who are dressed like himself, so that the people and especially the bride shall not be able to recognise him. The whole group proceed slowly towards the tent, the scribes all the time continuing their recitation. When they come near the tent the bridegroom and the two men who are dressed like him rush inside it. As soon as they begin to run, the men and boys of the bride's village beat them with sticks; and when they enter and pass through the tent the bride smacks one or more of them with her slipper (rähîya), while the other 
women inside the tent strike them with sticks. If the bride succeeds in hitting the bridegroom she is supposed to become his mistress; but it may also be that she, not recognising him, hits one of the other men.

After this ceremony is completed the bridegroom, together with the scribes, enter the compartment behind the curtain, from which the bride and her women companions have previously moved to the other part of the tent. The scribes ask the bridegroom for " a chicken," and after receiving from him a small sum of money and sugar, recite something from the Koran. The bridegroom's mother brings them dates and incense; the latter they burn and the dates they distribute to the bridegroom, to each other, to the bride and her mother, and to anybody who comes and asks for some and is willing to pay a little money for the gift and the blessing accompanying it. Persons who are desirous of offspring, or suffer from some illness, are particularly anxious thus to secure the blessings of the scribes, who first spit on the dates which they give them to eat. The scribes make fâtha on behalf of the bridegroom, and then go away with him, after which the bride and her female friends enter the division behind the curtain and remain there while the bridegroom is painted with henna outside the tent, as has been said before. The same evening, for some hours, the bridegroom's mother carries on her back a $\dot{g} u \mathbf{r} b a g l$, as if it were a baby.

Among the Ait Sádden the bridal procession, on 
arriving at the bridegroom's village, goes three times round the mosque, from right to left. While this is being done the bride mutters some words like these :"O Lalla Jẹbrîn (the name given by women to a mosque), bless me with sons who will become scribes." The bride and her company then proceed to the temporarily erected tent, into which she is to be taken, ${ }^{1}$ and go round it three times. At the commencement of this tour the men of the party take by force the headgears of the bridegroom's mother and sisters and those of the imsnein, as also the slippers of the bride, which must afterwards be redeemed by the l'âda brought by her mother. After the three circuits round the tent the procession stops outside its entrance. Turned towards the tent the bride, still on horseback, moves her head and hands as if she were praying, and says by herself four times :-Llâhû kbar, "God is most great." She then beats the tent three times with the remains of the cane which was broken by the men of the bridegroom's party on the road, and throws it at the tent; if it falls down on or behind the tent it is considered a good omen, whereas it is regarded as an evil foreboding if the stick does not reach the tent. This ceremony is intended to remove any evil which may be in the bridegroom's family and to expel death from the domestic animals; it would be very unpleasant for the young wife if a child or animal should die shortly after her marriage, as its death would naturally be

\footnotetext{
1 Among the Ait Sádden weddings are celebrated in small tents pitched for the
} occasion. 
associated with her presence. The bridegroom's mother sings :

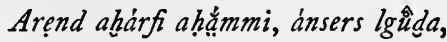

Bring a ram with black rings round its eyes ${ }^{1}$ (this being addressed to the bride), let us set down the excellent woman.

This song is repeated by the other women. The imsnein take down from the mare the saddle with the bride sitting in it, and thus carry her into the tent, which is filled with men, women, and children. A woman of the bridegroom's family puts into the bride's hand some butter, with which she smears the dhammar, or horizontal pole supporting the roof of the tent; this is done that there shall be an abundance of "grease"butter, oil, and honey. The bridegroom's sister, or some other woman of his household, pours barley into the bride's lap; the latter gets up and, with her face covered as before, goes to the mare outside the tent, lets it eat three times of the barley, and throws the rest over its head, so that there shall be much corn in the household. When she is back again the bridegroom's mother throws a silk kerchief round her neck and leads her by it to the four corners of the tent, saying at each corner one of the following sentences:-Häy azigyläl

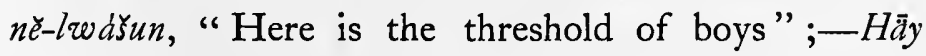
azig"lal n-wuilli d-izzyarn, "Here is the threshold of sheep and cattle";-Häy dzig"lal né-lmân dét-lhăna, "Here is the threshold of safety and quietness" ;-

I An aharrfi aḥ̣̂mmi, that is, a ram with black rings round its eyes, is considered to possess much baraka; it is therefore looked upon as the most suitable animal that can be chosen for sacrifice (Westermarck, "The Popular Ritual of the Great Feast in Morocco,' in Folk-Lore, xxii. [1911], p, 141). 
Häy ázigylal nắ-rrha, "Here is the threshold of cheapness." In former days, when the Ait Sádden lived in tents, the bridegroom's mother used to take the bride to the fireplace, but in this provisional tent there is no such place.

The bride now sits down on a mat. A bachelor lifts up one of the tirrsal (sing. tarrrelt), or vertical tentpoles, and puts it into her lap, in order that she shall remain in her new home and support it by becoming a mother of sons, as the tatrrselt supports the tent. While she is sitting with the tent-pole in her lap she is surrounded by the bachelors, to whom the imsnein distribute the dried fruit brought by the bride's mother as also the antimony and walnut-root, with which they paint their eyes and lips, and the hárrăqsus, with which they clear their voices. The bridegroom's mother comes and sings :

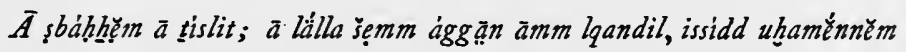
sigy ẫ

Oh good morning to you $\mathrm{O}$ bride; O lady you became like a lamp, your tent became very bright.

All the bachelors and women repeat the song to the accompaniment of tambourines. This ceremony is called așabbath-it is " the morning salutation" of the bachelors, although other persons join in it. The time when it takes place depends upon the hour when the bride arrives, and in case the weather is bad it may be postponed till the following morning when the guests who went away in the evening have returned. It is only after the așăbbdth that the bachelors are entertained 
with a meal, although the other people may already have been served with food on the arrival of the procession. The bride has her meal alone or with her mother or sister only, either in the tent after the people have left it, or in the house to which she retires to meet the bridegroom. She must not eat in the presence of the people nor speak to anybody nor be spoken to, and she has her face covered all the time.

Among the Ait Yúsi, when the bride and her company come near the bridegroom's village, they are sprinkled with milk or, if rain is wanted, with water, by villagers who come to receive them. The bride is not allowed to enter the village until she has been taken three times round it; but if, as is often the case, there are several brides whose weddings are celebrated on the same occasion they must wait for each other so as to perform this ceremony all together, and if any of them is from that village itself she also comes out and joins them, riding on a mare. In case there is in the village a woman who was married within a month previously, she leaves the place before the brides are taken round, since it is believed that otherwise all the evil would fall on her; this obviously shows that the ceremony in question is performed for the purpose of ridding the brides of the evil influences which they are carrying with them. If the village contains a mosque the brides also ride round it three times, and it may be that in such a case the tours round the village are dispensed with. While the bride is being taken round 
the village or mosque, volleys of gunpowder are discharged, and the bachelors and other young men try to rob her of something; this results in a fight between them and the imsnein, who are armed with sticks and swords, and the women as well, who all do their best to defend the bride. What is taken away from her is afterwards returned, but the robbers have to be compensated with a meal of aftual (seksu) with salt butter offered them by the bridegroom's mother, or with dried fruit brought by the mother of the bride.

After her tour round the village or mosque the bride is taken to the entrance of the bridegroom's tent ; in some parts at least of this tribe, weddings are always celebrated in tents. She stands up in the stirrups with her face turned towards the entrance, and the bridegroom's mother or sister, or some other woman of his family, gives her a palmetto tray (amidun) with red raisins, which she receives with both hands and throws over her head; the raisins, which are supposed to bring good luck on account of their sweetness, are picked up and eaten by the children. A lamb is handed to the bride by the bridegroom's mother or, if she has no lamb, by some other person, after which the bride hurls the animal over the tent-so that there shall be many sheep in the village. She beats the tent three times with the cane in her hand, in order that the evil shall go away from it; if shortly after the bride's arrival a death or some other unhappy event takes place in the village, it is attributed to her unlucky fringe (taunza), whereas good events indicate that she has a lucky fringe. 
When she has beaten the tent she flings the cane at the top of it. It is believed that if it falls down on the top the evil will go from the tent only, whereas if it falls down behind the tent the whole village will be cleared of the evil; but I have also heard that in the former case the husband will rule over his wife, whereas in the latter the wife will rule over her husband. The bride then stands up on the saddle, the imsnein keeping hold of her feet to prevent her from slipping, and moves both hands three times towards the East, each time repeating the words, Llâhu këbâr, "God is most great" ; this is called tazallit $n$-tslit, "the prayer of the bride." She sits down in the saddle, and is in this position carried into the tent by one of the imsnein, who subsequently replaces the saddle on the back of the mare. The bridegroom's mother puts some aftäl, made without butter, into the lap of the bride, who walks out and three times gives the mare a little of it to eat, then throwing the remainder in its face. The object of this ceremony is said to be to remove from the mare the evil influences with which it is affected on account of having been ridden by the bride and which would otherwise cause its death or barrenness; for there is baraka both in the bride and the mare, and if baraka comes into contact with baraka it may lead to disastrous consequences. When the bride is back again in the tent, one of the imsnein takes her on his right shoulder and the bridegroom's mother gives her some salt butter to smear on the horizontal pole supporting the roof of the tent, in order that there shall always be butter in 
the larder. The amsnai dances a little with the bride seated on his shoulder and then sets her down on her bed.

Meanwhile the guests have been entertained with afttäl and salt butter, neither bread nor meat being served on this occasion. If several weddings are celebrated simultaneously, the people who have assembled outside the wedding-tents come together to be counted and divided into groups of equal numbers, to be treated by the families of the various bridegrooms, the divisions being made on the principle that people from the same village shall eat together. After the meal there is music, singing, and dancing outside and inside the tents. When most of the guests have left the tent where the bride is, the bridegroom's mother offers her some afttal on her uncovered right thigh, and the bride snaps up a little of it three times, slightly biting the mother-in-law; this is supposed to make the two women friendly to each other.

Among the Ait Nder the procession goes seven times round the tent in which the bride and bridegroom will meet. It is in most cases a small tent, provisionally pitched, where the bride spends the first seven nights and days and not infrequently the seven following nights as well ; but sometimes the meeting takes place in an enclosure (t $t \dot{u} \dot{g} l i l t)$ in the middle of the tent occupied by the bridegroom's family. Persons belonging to the latter throw dried figs over the bride and the mare she is riding - " so that everything shall be sweet," 
like the figs. When the animal stops outside the entrance of the tent, the same man as previously lifted the bride into the saddle now lifts the saddle with her sitting in it inside the tent and puts it down on the bed, where it is left for seven days. The bride gets up and kisses the head of the man, who gives her a silver coin for good luck. A woman of the bridegroom's family pours some barley into a fold of her clothes; she walks with it to the entrance of the tent where the mare is standing, gives the animal to eat of it, and throws the rest over its head. The woman also puts some salt butter into the bride's right hand and lifts her up so that she can reach the ahammar, or horizontal pole of the tent, on which she smears the butter. She then sits down on the bed, and other women, married as well as unmarried, keep her company, playing and singing. They all have supper there; but when the bride eats she hides herself underneath her clothes, and when she has something to say to any of the women she only speaks in a whisper. The other women go away leaving the bride alone to receive the bridegroom.

Among the Ait Warain the procession is met outside the bridegroom's village by the villagers. The bride throws over her shoulder her taberdö $t$, which with its designs gives her a more picturesque appearance. The bridegroom's mother offers her milk, as also some flour in a palmetto or esparto tray (ándî or tändutt); of the former she drinks a little and sprinkles some on the people, and of the latter she takes a double handful and 
throws it over her head to get rid of all the evil influences attached to her. She stands up on the packsaddle making fâtha with both hands without saying anything, and the people round her likewise hold out their hands calling down blessings on themselves. Still standing on the mule, she takes some dried fruit from the skin-sack (tamzitt) and throws it on the people, who are so anxious to eat of it that persons who have not been able to catch any even buy some from others who have been more successful; on account of the bride's baraka it is supposed to remove evil from those who partake of it. The mule is now led seven times from right to left round the little mosque outside the village ; this was said to be a salutation to the ditmort (contraction of ait tmort), that is, the spiritual masters of the place, including both saints and $j n \bar{u} n$.

The procession enters the village and stops outside the bridegroom's dwelling. His brother lifts the bride from the mule and carries her inside the house or tent, where she goes and sits down on the bed. The unmarried girls keep her company, playing and singing, and they all have a meal together. The bridegroom's mother enters and, after the bride has kissed her hand, takes her to the fireplace (timssi) and washes her right foot and hand over one of the three fire-stones (inyan), in order that she shall be as permanent in the house as these stones, which the Ait Warain, unlike many other Berbers, never change. The water is then sprinkled on the cattle, so as to make her fond of them. The bridegroom's mother also takes the bride's silk kerchief 
(tásebnist), or cotton kerchief (táš̌nbừ̌t), and ties it very firmly on the head of a donkey; if it remains there till the following morning, it is a sign that the wife, too, will remain with her husband, whereas, if the kerchief has come off before then, it is believed that they will soon separate.

In one division of this tribe, the Ait Hăssan, it is the custom for the bride, when she arrives at the bridegroom's village, to be taken to a tárga, or little watercourse made for the purpose of watering the soil, where she dismounts. There she meets the bridegroom, standing on the other side of it. He pushes a piece of cane over the surface of the water towards the bride opposite him. If it floats straight across to her it is a good omen, indicating that the husband himself will be straight, whereas the opposite will be the case if it takes another course. The bride then returns the cane in the same manner towards the bridegroom, and now it is her future conduct that is indicated by the way in which it floats over the water.

Among the At Ubáhti the bride is taken seven times round the bridegroom's tent from right to left and then stops outside the entrance. His mother throws over her figs, dates, or raisins, which the people pick up and eat; the object of this ceremony was said to be to make the bride "sweet" to the bridegroom's family. His mother then sprinkles water on her, which is supposed to produce a rainy season and make the year good. The bride makes no fât tha, as is done 
in other tribes. The bachelor who lifted her on to the animal now takes off the saddle (tritht) with her in it, and carries her thus into the tent, where he puts his load on the bed prepared in an enclosure (t túglglelt) in the middle of the tent. But before they enter the tent two or three bachelors fire off their guns so close to the bride that she is quite enveiled in the smoke; this was said to be done in order to prevent her evil influences from affecting the $i s l a n$. The saddle remains in the tent till the following morning, and the bridegroom's mother smears on it henna, or some blood of the sheep or goat slaughtered by her husband, so that it shall cause no harm; I was told that the slaughter of the animal for the purpose of providing the wedding party with food serves at the same time the object of removing the danger attached to the saddle in which the bride has been riding. Sitting on the bed she takes off her belt ; for contrary to the custom of many other tribes she has come there with her belt on. She is attended by a young married woman friend, who, however, leaves her alone before the bridegroom enters.

Among the Ait Wäryâgäl the bride, on her arrival at the bridegroom's house before sunset, is welcomed by his mother with milk, into which she dips the little finger of her right hand. The man who lifted her on to the mule-her brother or uncle-has a sham-fight with the bridegroom: he takes a flag which the women have brought with them and goes to the door of the bridegroom's house, inside which the latter himself is stand- 
ing, likewise holding a flag in his hand, and the two men, on either side of the threshold, now knock the flag-staffs together. The bridegroom's father, or some other member of his family, gives to the bride, still sitting on the mule, some barley, which she throws on the people round her; they catch of it what they can and mix it with their own barley so as to give it the benefit of the bride's baraka.

The man who had the fight with the bridegroom lifts the bride from the mule into the house, where he passes with her between the bridegroom's legs-so as to make her a good wife. The bridegroom then takes her in his arms and puts her down on the bed, removes her headgear, kisses her on her cheeks, and leaves the room. Outside the house he is attacked by all the women assembled there, who strike him with their fists; but he makes his escape through the crowd with a dagger in his hand, without hitting anybody. He goes and sits down with the iuzirẹ̣n in the yard, and then has his supper with them in a room, spending the night in their company. His own room is after his departure invaded by the women, including his mother, who have their supper with the bride and also spend the night with her; but before they go to sleep they dance and sing in the yard, while the men are firing off their guns in the air. It should be added that after the bride is lifted into the bridegroom's room, the boy who led the mule rides on it three times round the house; he then removes the bridle and hides it somewhere, or gives it to somebody to keep for him, the bridegroom having 
to buy it back for a peseta or two. Next morning a meal is served to the guests, after which they go away; but before the women leave, the bridegroom must give each of them a silver coin as a present.

Among the Shloh of Aglu, when the procession arrives at the bridegroom's house in the evening, the camel is made to kneel down, and the bride is carried into the house by her brother or some other male relative. While she is taken there the people of the procession protect her with a blanket against the bridegroom, who is throwing down dates, almonds, and raisins from the roof where he is sitting with his luzîr. The women sing :-L'âdaňk a mûläi, "Your custom, $\mathrm{O}$ my lord." The dried fruit is shaken off the blanket and picked up and eaten by the people. The bride is put down on a bunk, to which she must be carried, as it would be bad for her to walk. While she is sitting there the bridegroom's mother takes to the door two small pails (tálmärjlin, sing. tálmărjęlt), one filled with milk and the other with water, which are handed to the bride by the girls attending her; she drinks three times from each, only uncovering her mouth. She hardly eats anything that evening, so that she shall not be obliged to leave her bed, nor does she speak much. The bridegroom, who spends his time out-of-doors in company with his male friends, only comes to her in the evening of the following day, which she passes on her bed, without treading on the floor. It should be added that in Aglu all the young men of a village who 
marry in the same year have their weddings on the same day in the autumn. If shortly after the weddings there should come locusts instead of the expected rain, the newly married people are taken outside the village and told to make sacrifices at a saint's tomb so as to put a stop to the plague, which is supposed to have been caused by their weddings.

Among the Ait Támeldu the same man as lifted the bride on to the mare or mule also lifts her down when she arrives at the bridegroom's place. She walks into his house accompanied by other women, and in this tribe also it is the custom for the bridegroom, sitting on the roof or upper floor of the house, to throw down dried fruit-dates, walnuts, and figs, - as well as bread, on the blanket held over the bride and on the people round her. This ceremony was said to serve the object of averting the evil eye from the bride, as the things thrown would attract the looks of the people. After she has entered the house the bridegroom's mother gives her milk to drink; and she spends there the night in the company of other women. This evening is called $\ddot{u} d n$-tmigra, "the night of the wedding."

Among the Igliwa the procession makes a halt at a little distance from the bridegroom's house, at the door of which his family are standing, crying out their welcome. The bride's brother, or some other man of the party who is a good speaker, answers that they will not enter until the things agreed upon are given them. $\mathrm{He}$ is asked, "What do you want?" to which he replies, "We want slaves for the wife, a male and a 
female." This and the rest of the dialogue, however, is only a sham one. The bride is received with dates, flour, henna, and milk. After she has bowed her head three times towards the East, she dips the little finger of her right hand into the milk and wipes it on the mane of the mule. Her people ask, "Where are the dates?" The bridegroom and his friends, who are sitting with him on the roof of the house, reply, "They are coming with camels from Sahara." They then begin to throw dates on the blanket with which four men are protecting the bride from the bridegroom's attempt to strike her with the cane he holds in his hand. Her people ask for more and more dates, and at an opportune moment the man who lifted her on to the mule takes her down and rushes with her into the house. If he does this so cleverly that she escapes the blow intended for her, the bridegroom is put to ridicule.

At Amzmüz, when the bride arrives at the bridegroom's house, a man fires a shot inside the room she is going to occupy, after which she is taken down by the man who lifted her on to the mare and carried straight to the bed. As she approaches the door the bridegroom, who is sitting on the roof, throws on her head walnuts, dates, almonds, and grit removed from the wheat on the day when it was cleaned $;^{1}$ and the fruit is picked up and eaten by the children.

It appears from these descriptions that the ceremonies which are connected with the bride's arrival at

1 See supra, p. 95. 
the bridegroom's place are largely intended to prevent her from carrying evil with her to her new home. For this purpose she is taken either three or seven times round the bridegroom's house or tent or the mosque of his village or the village itself. ${ }^{1}$ The milk or water which is offered her or sprinkled upon her ${ }^{2}$ in all

1 Among the Bedouins of Mount Sinai the bride, mounted on a camel, is taken three times round the bridegroom's tent, while her companions utter loud exclamations (Burckhardt, Notes on the Bedouins and Wahábys [London, 1830], p. 150). Dr. Seligmann informs me that among the Kabbabish, an Arabic-speaking nomad tribe on the Kordofan-Darfur border, the slave or slaves who bring the bride to the tent where she is going to meet the bridegroom carry her three times round the outside of it. Among the Touareg of the Ahaggar "les hommes amènent le marié à la tente. On lui en fait faire le tour trois fois" (Benhazera, Six mois chez les Touareg du Ahaggar [Alger, 1908], p. 16). Cf. the Indo-European custom of taking the bride round the fireplace (Haas, 'Die Heirathsgebräuche der alten Inder,' in Weber's Indische Studien, v. [Berlin, 1862], pp. 316 sqq., 396; Winternitz, 'Das altindische Hochzeitsrituell,' in Denkschriften der Kaiserl. Akademie der Wissenschaften, Philos.historische Classe, xl. [Wien, 1892], p. 57 sqq.; Crooke, The Popular Religion and Folk-Lore of Northern India, i. [Westminster, 1896], p. II :-“"In India the bride and bridegroom are made to revolve round the sacred fire or the central pole of the marriage-shed"; v. Schroeder, Die Hoch $\approx$ eitsbräuche der Esten und einiger andrer finnish-ugrischer Völkerschaften, in Vergleichung mit denen der indo-germanischen Völker [Berlin, 1888], p. 127 sq9.; Samter, Familienfeste der Griechen und Römer [Berlin, I901], p. 20 sqq.), which may also have been a purificatory rite; in his description of the wedding ceremonies of ancient India Dr. Winternitz (loc. cit. p. 42) remarks :"Dass man Böses von der ins Haus einziehenden Frau befürchtete, geht aus verschiedenen Versen hervor." In Perthshire it is, or was, the custom for bridal processions to go round the church (v. Reinsberg-Düringsfeld, Hochzeitsbuch [Leipzig, 1871], p. 236). Of the Jews in Morocco Addison (The Present State of the Ferws [London, 1676], p. 52) writes:- "At the Wife's first meeting of her Husband she walks thrice about him, because the Scripture saith, A woman shall compass a man, Jer. 31. 22. And the Man walks once round the Woman."

2 Among some Algerian Berbers, "dès que la mariée a mis pied à terre pour pénétrer dans sa nouvelle demeure, on lui fait boire du lait frais, du leben (lait aigri) et de l'eau " (Féraud, 'Mœurs et coutumes kabiles,' in Revue africaine, vi. [1862], p. 430 sq.). The peasants of Palestine place on a bride's head a jar of water, which she is to carry thus into the bridegroom's house; and if she be too tall to pass under the doorway with the jar on her head, an egg is substituted for it (C. J. Wilson, Peasant Life in the Holy Land [London, 1906], p. 114). In Rome it was the custom to receive a bride "with water and fire" (aqua et igni accipere); see Rossbach, $o p$. cit. pp. 351, 361 sqq., and Samter, op. cit. p. 14 sqq. Water ceremonies have been practised at weddings in many other European countries (v. Schroeder, op. cit. p. 133 sqq.), as wcll as in ancient India (Haas, loc. cit. pp. $341-342,35^{8}, 365,367,373$ ). 
probability serves the same object, even though the sprinkling of water sometimes is said to bring about rain. She is also received with grain, flour, bread, séksu, $t\} \hat{\imath} \zeta^{3} a, t^{s} r d d$, or red raisins, and very commonly dried fruits-raisins, figs, dates, walnuts, or almonds-are thrown over her or the bridal box by the bridegroom's mother or other people of his family or the bridegroom himself or, in one case, by a woman of the bride's family. ${ }^{1}$ The throwing of bread and dried fruit is in

1 Among some Algerian Berbers, after the bride has drunk the milk and water offered her, "on lui donne une poignée de blé, d'orge et de sel, qu'elle doit jeter, à droite et à gauche, par dessus ses épaules ; c'est, disent-ils, pour faire descendre la bénédiction et l'abondance dans la famille" (Féraud, loc. cit. p. 431). Among the Maronites "the bride, conveyed to her new home, is pelted with corn and raisins, and on arriving she flings a pomegranate amid the party, which is greedily seized and divided by the bridegroom's companions (Conder, Heth and Moab [London, I 885], p. 293). The custom of throwing grain, seeds, or dried fruit of one sort or another over the bride or over the bridegroom as well, or sometimes over other persons present at the wedding, has been observed from India to the Atlantic Ocean (Winternitz, loc. cit. p. 75 sqq.; Crooke, op. cit. ii. 26 sq.; Mannhardt, op. cit. p. 354 sqq.; Schroeder, op. cit. p. 112 sqq.; Samter, op. cit. p. 1 sqq.; Brand, Observations on the Popular Antiquities of Great Britain, ii. [London, 1849], p. 101 :-“The English, when the bride comes from church, are wont to cast, wheat upon her head"). Mannhardt (op. cit. p. 365 sqq.) and Mr. Hartland (Primitive Paternity, i. [London, 1909], p. 109) think that this custom is intended to promote fecundity; and so it obviously is in certain cases. Addison (op. cit. p. 52) states that, among the Jews of some countries, "the Guests bring with them handfuls of corn, which they cast at the New-Married, saying, Increase and Multiply. By which they also wish them Peace and Abundance." With reference to the present Jews of Morocco Dr. Jansen ('Mitteilungen über die Juden in Marroko', in Globus, lxxi. [1897], p. 359) writes :- " 14 Tage vor der Trauung wird an einem Donnerstage an der Tür des Brautzimmers ein Krug voll Getreide zerschlagen, mit der symbolischen Bedeutung, dass die Braut fruchtbar sein moge." Mr. Crooke (Things Indian [London, 1906], p. 319) says that rice or wheat is poured over the heads of the pair with the object "to annul the influences which would prevent the fertility of the union" ; but he also observes (Popular Religion and Folk-Lore in Northern India, ii. 26) that one object of this rite "would seem to be to keep in the soul which is likely to depart at such a crisis in life as marriage." Dr. Samter (op. cit. p. 2), again, remarks that in Greece dried fruits were thrown not only over a bride but over a newly bought slave as well, and that the custom in question, therefore, must have had another object than that of ensuring fecundity. He suggests that it was originally meant as a food-offering to spirits which required propitiation (ibid. p. 7 sq.; 
one tribe supposed to increase the food-supply for the married couple and also to benefit others, who pick up what falls on the ground and use it to impart the bride's baraka to their corn; whereas in another tribe this custom is looked upon as a method of averting the evil eye from the bride. ' Sometimes the raisins, figs, or dates are said to bring good luck, or to make everything sweet, or to make the bride sweet to the bridegroom's family; and the trid, barley, or wheat which is offered her and then thrown by her on the people is said to give them the benefit of her baraka or to make the year good. But in two instances the wheat, flour, séksu, or $t \xi \hat{\imath} \hat{\zeta}_{a} a$ which she throws over her head is represented as a means by which she rids herself of evil influences, and in one instance the dried fruit which she throws on the people is said to remove bas from those who partake of it. The offering of henna to the bride on her arrival at her new home no doubt serves a purificatory object, and this may also be the case with the bridegroom's attempt to strike her with a cane, though it has the appearance of a ceremony by which he tries to get power over her. ${ }^{2}$ It is for the express purpose of

Samter, Geburt, Hochzeit und Tod [Leipzig \& Berlin, I9x1], p. I72 sqq.); and the same opinion has been expressed by M. Reinach (Cultes, mythes et religions, i. [Paris, 1905], p. 117) and Herr Sartori (Sitte und Brauch, i. [Leipzig, 1910], p. 91). This explanation gains no support from Moorish ideas. Professor Schroeder (op. cit. p. $210 \mathrm{n}^{\mathrm{I}}$ ) thinks it probable that the Jews have borrowed the custom from IndoEuropeans, as it is not known to have prevailed among the ancient Hebrews; and the same may have been the case with the people of Northern Africa.

I In Palestine (Lydia Einszler, 'Das böse Auge,' in Zeitschrift des Deutschen Palaestina-Vereins, xii. [1889], p. 208) and Syria (van Kasteren, "Aus dem 'Buche der Weiber," ibid. xviii. [1895], p. 49) the throwing of grain and salt at a wedding is likewise looked upon as a charm against the evil eye.

2 "It is said that as a Druze bride enters her husband's door he gives her a smart 
expelling evil that the bride beats the bridegroom's tent ; and to the same class of ceremonies seems to belong the short religious rite she performs while still on the animal, nothing being more purifying than prayer. There is, moreover, the quivering noise of women, loud music, and the firing off of guns, ${ }^{1}$ the purificatory or protective character of which is particularly obvious when it is done so close to the bride that she is enwrapped in the smoke or when a shot is fired inside the room which she is going to occupy. In one instance the shots are said to prevent her evil influences from affecting the islän.

The animal which the bride has ridden must also be purified in some way or other : a boy rides on it three times round the house, or the bride wipes the finger which she has dipped in the milk offered her on the mane of the mule, or the bridegroom's mother throws an egg, which she has dipped into milk and flour at its forehead, partly, I presume, to purify the mule, ${ }^{2}$ or the

blow with a stick, to show that she is under his rule and authority" (Wilson, op. cit. p. 114). Among the Maronites the bridegroom, standing on the flat roof of the house over the aoor, holds a sword above the head of the bride (Conder, op. cit. p. 293). Among the Algerian Berbers already referred to, after the bride has thrown grain and salt over her shoulders, "le mari s'approche, à son tour, et lui tire, à hauteur de la tête et presque à bout portant, un coup de fusil ou de pistolet qui, parfois, met le feu à sa coiffure. Cette grossière galanterie est le prélude de l'assujettissement de la femme, elle l'avertit que son mari est désormais le maître absolu de son existence" (Féraud, loc. cit. p. 431).

1 Among the Touareg of the Ahnet, at the moment when the bridal procession arrives at the bridegroom's tent, "on tire quelques coups de fusil" (Bissuel, Les Touareg de l'ouest [Alger, 1888], p. 105).

2 In Andjra it is also the custom that, when a person buys a horse, mule, or donkey, he breaks an egg against its forehead; besides which he puts a dollar-piece or some other silver object on the ground and makes the animal walk over it. In the Hiáina, when a horse is bought, an egg is likewise broken against its forehead, and some white wool is tied to its right foreleg. Among the Igliwa a newly bought horse or mule is taken over a bowl of milk which has been placed on the threshold 
bride gives the animal barley or sěksu to eat, throwing the rest in its face or over its head. The object of the last-mentioned ceremony is sometimes said to be to remove from the mare evil influences which would otherwise cause its death or barrenness, sometimes to make the corn plentiful in the household, and sometimes both to make the year good and the mare fruitful; but I think we have reason to believe that, whatever ideas may now be connected with this ceremony, it was first suggested by a feeling that the animal with which the bride had been in so close a contact was in need of purification. It is for a similar reason that the saddle is sometimes smeared with henna or blood.

The custom of taking the bride into the bridegroom's house behind a cover of blankets may, like her veiled face, be intended to protect the people from her dangerous glance, at the same time as it shelters her from their looks; as said before, she is both a source of danger to others and in a state of danger herself. For the latter reason she must be carried to the nuptial bed or across the threshold, ${ }^{1}$ which

of the house or on some flour strewn on it. It was pointed out to me that the good effects of the egg, wool, milk, and flour are due to their whiteness and, in the case of the wool, to its baraka also, which it possesses as coming from a holy animal.

1 In Palestine "a bride is often carried over the threshold that her feet may not touch it, to do so being considered unlucky" (Wilson, op. cit. p. 114); and in Cairo the bridegroom, who meets the bride when she arrives before the gate of his dwelling, "suddenly clasps her in his arms as if by violence, and running off with his fair prize carries her into the females' apartments up stairs (Burckhardt, Arabic Proverbs [London, 1830], p. I16). The custom of carrying a bride over the threshold has prevailed in Rome (Rossbach, op. cit. pp. 351,359 sqq.) and many other countries both in Europe and elsewhere (v. Schroeder, op. cit. p. 88 sqq.; Trumbull, The Threshold Covenant [New York, 1896], p. $3^{6}$ sqq. ; Samter, Geburt, Hochzeit und Tod, p. 136 sqq.). In ancient India a bride was not allowed to step on the threshold (Winternitz, loc. cit. pp. 23, 72). 


\section{is considered haunted by $j n \bar{u} n$, presumably on account} of that uncanny feeling which superstitious people are apt to experience when they first enter a dwelling $;^{1}$ although the carrying of the bride into her new home may, at the same time, be a ceremonial expression of the reluctance which a virgin pretends to feel against being given away in marriage. ${ }^{2}$ Owing to her

1 In Morocco nobody is allowed to sit down on the threshold of a house or at the entrance of a tent; should a person do so he would get ill himself or give bas to the house. So also it would be unlucky for the house and its inhabitants if anybody should pull up the backs of his slippers on the threshold. Chenier (The Present State of the Empire of Morocco, i. [London, 1788], p. 277) says that when the bride enters the bridegroom's house, her relatives carefully observe that "she shall not touch the threshold of the door." Dr. Samter (Geburt, Hochzeit und Tod, p. 140 sqq.), following Dr. Winternitz (loc. cit. p. 72), maintains that the threshold is feared because it is believed to be haunted by the souls of dead people, and thinks that this belief may have originated in an earlier custom of burying the dead underneath the threshold, although he can adduce no evidence for this supposition. The Moorish jnunn, however, are not the souls of departed men, nor can it be proved that the ancient Arabic jinn were souls. They seem to have been beings invented to explain or personify the mysteries of nature (see Westermarck, 'The Nature of the Arab Ginn, illustrated by the Present Beliefs of the People of Morocco,' in Fournal of the Anthropological Institute, xxix. [1900], p. 252 sq9.); and as for the jnun haunting the threshold, I have little doubt that they simply owe their origin to that uncanny feeling mentioned in the text.

2 Cf. Crawley, The Mystic Rose (1902), p. 350 sgg. In Turkey, when the bride arrives at the bridegroom's house, " she is expected, for the sake of appearances, to show great reluctance to enter" (Hutchinson, Marriage Customs in Many Lands [London, 1897], p. 79). With reference to the ancient Romans, Plutarch (op. cit. 29) writes : - "Why do they not permit the new married woman herself to step over the threshold of the house, but the bridemen lift her over? What if the reason be that they, taking their first wives by force, brought them thus into their houses, when they went not in of their own accord? Or is it that they will have them seem to enter into that place as by force, not willingly, where they are about to lose their virginity?" Many modern writers have likewise tried to explain this custom as a survival of marriage by capture, e.g. Rossbach (op. cit. p. 360), Lord Avebury (The Origin of Civilisation [London, 1912], p. 102), Schroeder (op. cit.p. 92), and Jevons (in his edition of Plutarch's Romane Questions [London, 1892], p. xcv. sq.); but without success (cf. Samter, Geburt, Hochzeit und Tod, p. 137 sq.; Zachariae, 'Zum altindischen Hochzeitsritual,' in Vienna Oriental Fournal, xvii. [1903], p. 140 sq9.). In many cases the man who carries the bride over the threshold is neither the bridegroom nor any of his friends, but a man of her own family ( $c f$. Crooke, 'The Lifting of the Bride,' in Folk-Lore, xiii. (1902), p. 239); and side by side with the custom of lifting the bride, there is the custom which simply requires her to avoid stepping 
dangerous condition the bride must be silent, ${ }^{1}$ or only speak in a whisper, and avoid being seen eating; and in one instance the man who carries her to her bed pricks it with his dagger to make it safe for her.

Besides ceremonies which, though probably purificatory in their origin, are looked upon as means of positively promoting the welfare of individuals, the family, or the whole community, there are others which no doubt from the beginning have been practised with such objects in view. The bride hurls a lamb over the bridegroom's tent so that there shall be many sheep in the village. She smears the horizontal pole of the tent with butter so that there shall be an abundance of butter or "grease" in the household." She is taken

upon the threshold. Equally unsatisfactory is Zachariae's suggestion (loc. cit. p. I42 sq.) that the chief feature of the ceremony is the lifting-up of the bride, not her avoidance of touching the threshold with her feet. "Das Heben an sich," he says, "war augenscheinlich eine feierliche, bedeutsame Handlung. Personen, die man feiern oder ehren wollte, wurden in die Höhe gehoben : so bei der Hochzeit die Braut und . . . auch der Bräutigam." This may apply to some other ceremonies mentioned above, but does not explain why the bride is carried over the threshold ( $f f$. Samter, op. cit. p. 138 sqq.). The Roman custom of lifting a bride over the threshold has been said to serve the object of preventing the bad omen which would be caused by her stumbling on it (Preller, Römische Mythologie [Berlin, 1865], p. 585). According to Mr. Crooke (loc. cit. p. 242), "the lifting over the threshold may . . . be in some cases a fertility charm ; in others it may have been intended to protect the bride from some contamination, or to avoid ill-luck."

${ }^{1}$ Cf. Customs and Manners of the Women of Persia, translated by Atkinson (London, 1832), p. 70 :- “The bride herself must not speak to any one." See also Crawley, op. cit. p. 342.

2 In Algeria, says M. Villot (Mours, coutumes et institutions des indigienes de l'Algérie [Alger, 1888], p. I05), "la jeune épouse est amenée jusque sur le seuil de sa nouvelle demeure; la belle-mère l'y reçoit et lui tend un pot de beurre. La jeune fille y plonge la main et, après l'en avoir retirée, elle enduit de beurre les montants de la tente. Cette cérémonie, dont l'origine se perd dans la nuit des temps, a pour but de faire descendre la bénédiction du ciel sur le jeune ménage." In Palestine, again, "when the bride comes to her husband's house, she has, before entering, to place a piece of leavened dough on the doorpost. This act is a wish that as the leaven placed in a mass of dough increases till the whole of the mass is 
to the four corners of the tent as representing the "thresholds" of boys, of sheep and cattle, of safety and quietness, and of cheapness. Other ceremonies are performed by her or her mother-in-law to make her fruitful ${ }^{1}$ and, particularly, a mother of sons; to make the two women friendly to one another $;^{2}$ to make the bride a good wife; to make her permanent in the house; or to make her fond of the cattle. In this . connection we should also remember the belief mentioned in the last chapter, that it is a good omen for the people of her new home if she arrives there at the same time as the flocks and herds return from the pastures. ${ }^{3}$

leavened, so she may have a numerous family, and by her the clan may grow and be increased" (Wilson, op. cit. p, I I4). The same custom is mentioned by Abêla, 'Beiträge zur Kenntniss abergläubischer Gebräuche in Syrien,' in Zeitschrift der Deutschen Palaestina-Vereins, vii. (1 884), p. 93 ; Conder, op. cit. p. 293 (Maronites); Trumbull, op. cit. p. 28 sq. (Upper Syria); Jaussen, Coutumes des Arabes au pays de Moab (Paris, 1908 ), p. 54. In Rome the bride anointed the door-posts of the bridegroom's house with grease or oil and hung wool on them (Rossbach, op. cit. pp. 351, $35^{6}$ sqq.; Samter, Familienfeste der Griechen und Römer, p. 80). For the use made of wool in magical practices in Morocco, see supra, p. 218 sq.n. 2 ; infra, p. 26r. Among the Jews of Morocco the bridegroom dips some cotton-wool in a mixture of honey and henna and then fixes it together with a silver coin on the head of the bride, "als Zeichen ihres künftigen Wohlbefindens und Gedeihens" (Jansen, loc. cit. p. 360).

1 "A Kérak et à Mādabā, lorsque l'épouse entre pour la première fois dans la maison de son époux, on écrase une grenade dont on disperse les grains pour figurer les nombreux enfants attendus de ce mariage" (Jaussen, op. cit. p. 54). Eijūb Abēla (loc. cit. p. 93) gives the following description of the manner in which a Syrian bride is received:- “Wenn die Braut bei der Thüre des Hauses ihres Bräutigams anlangt, giebt man ihr ein Stück Sauerteig, damit sie es über der Thüre befestige. Auch legt man auf die Schwelle einen Granatapfel, auf welchen sie treten muss, so dass die Körner auseinanderstieben. Dadurch gewinnt man die Überzeugung, dass sie mit der Familie des Mannes in gutem Einvernehmen leben und viele Kinder bekommen werde."

2 At Aleppo, as soon as the bride has arrived at the bridegroom's house, his mother "rompt en deux avec elle une grosse pastille de sucre, et ayant à la main un morceau de candi, elle le lui met dans la bouche pour qu'elle ait le parler doux avec sa belle-mère" (Guys, Un Dervich algérien en Syrie [Paris, 1854], p. 202).

3 Among the Touareg of the Ahnet, on the other hand, "la marche est calculée de manière à ce que le cortège arrive à la tente du mari à l'instant du dohor" (duhr), i.e. at 1.30 P.M. (Bissuel, op. cit. p. 105). 
The bride is generally lifted into the bridegroom's house or tent by the same man as previously put her on the animal, but sometimes it is the bridegroom's brother or cousin that takes her in although it was her own brother or cousin that mounted her. In one case, where a woman of her kin has lifted her into the bridal box, and her brother has lifted her out of it, a woman of the bridegroom's family carries her into his house ; and in another case the bridegroom himself puts her down on the bed after her brother or uncle has carried her into his room. ${ }^{1} \quad$ There is a ceremonial fight between these two men, and the bridegroom is besides attacked by the women. In other instances the bridegroom and friends of his who are dressed like him are struck by the men and women of the bride's village, including the bride herself, who thereby hopes to become his master; or the bridegroom tries to strike the bride; or the men of the procession rob the bridegroom's mother and sisters and the imsnein of their headgears and the bride of her slippers; or the bachelors and other young men try to take something from the bride, who is defended by the other women and the imsnein; or the women curse both her and the bridegroom's father, as if the marriage were an offence against their sex; and in one instance the bride's brother refuses to proceed to the door of the bridegroom's house. ${ }^{2}$ In

1 Cf. Féraud, loc. cit. p. 43 I (some Algerian Berbers).

2 Among the Touareg of the Ahaggar, at some yards' distance from the bridegroom's tent "le fils de la tante maternelle de la mariée s'avance et veut retenir la mariée, en lui disant: 'Je ne te laisserai pas partir avant d'avoir reçu mon cadeau, mes sandales.' . . . Le marié ou ses amis lui font alors passer une paire de sandales mises de côté à son intention ou, à défaut, un autre cadeau" (Benhazera, op. cit. 
these customs we find a ceremonial expression of the antagonism between different social groups represented at a wedding, and of the husband's and wife's desire to rule over one another. But at the same time it seems quite probable that they have a purificatory significance as well, as is the case with sham-fights on various other occasions in Morocco.

p. 17). Among the Arabs of Moab, if the bride is brought from a neighbouring tribe, a curious scene takes place when the procession approaches a camp in the bridegroom's tribe :- "Les femmes du campement se réunissent, poussent des cris, ramassent des pierres, les jettent sur la fiancée, fort accroupir son chameau, la traînent par terre, se mettent à la frapper; le sang coule; mais les hommes ne tardent pas à mettre un terme à ce combat féminin. La même scène se renouvelle, paraît-il, chaque fois que le cortège doit passer auprès d'un campement, avant d'arriver à celui du fiancé. Les femmes de la tribu ne veulent point recevoir cette étrangère, dont l'arrivée paraít être une insulte à leur beauté ou à leurs attraits" (Jaussen, op. cit. p. 53). 


\section{CHAPTER VII}

THE MEETING OF THE BRIDE AND BRIDEGROOM AND THE MORNING AFTER

$\mathrm{W}_{\mathrm{E}}$ shall return to the bridegroom at Fez, whom we left in dar islän when we accompanied the bride to dar l-örs.

On their arrival at dä islän the ngâgef, sent there by the bridegroom's mother, remove his clothes and put on him the new ones which they have brought with them ; being black women they have no shame in doing so. On this occasion, however, the white farajîya, which is otherwise worn over the coloured qaftan, ${ }^{1}$ is omitted, and he has no belt (h̆ăzâm) put round him. With his $k s a$ pulled over his face he walks to his house surrounded by the ngâgef and followed by his male friends. When they arrive at the door the ngâgef make a quivering noise as a signal to the women inside to go upstairs. On entering the house his friends remain in its centre while he himself and the $n g \hat{a} g e f$ proceed into the nuptial chamber, where he mounts one of the lower steps of a ladder leaning against the pile of

1 Whilst the qdftan is buttoned all down the front, the farajiya is only buttoned from neck to waist. 
mattresses opposite the entrance. A nggâffa with a wax candle in her hand stands on either side of him, while the other ngâgef stop near the door. One of the latter holds in her hand an empty bowl, another a bowl with milk, and a third a bowl containing dates. The men come one by one and put into the empty vessel some money, which is taken by the ngâgef; the second $n g g \hat{a} f a$ gives the donor some milk to drink, and the third one hands to him a date to eat. While this is going on the ngâgef sing :

Allàh $m^{2} a$ șhäb lă-rû̀s,

May God be with the bridegroom's friends;

and the women upstairs make a quivering noise. When all the men present have thus given their tribute and been rewarded with some milk and a date, they go back to dar islān and the women come down again. The bridegroom gets off the ladder and enters the dăḩ̌̂̌sa accompanied by a nggâfa, who takes off his hâỵ̆k and removes the bride's ornaments, putting the latter in a box standing in the däḩûya. After she has locked the box and given the key to the bride, she goes away and closes the door, leaving the bride and bridegroom alone. The other ngâgef have already left the room.

The bridegroom now passes a while with the bride. Before they part she gives him two cotton kerchiefs (drer, sing. derra) embroidered with silk, one of which he ties round his waist as a belt, using the other as a handkerchief, and a $t^{s} e^{k} k a$, or cord for keeping up the trousers, with embroidered and fringed ends to hang 
down in front; and it is the custom that the bride herself should thread this cord through the trousers. The bridegroom then goes alone to dar islän, after which one of the ngâgef, the so-called gellâsa, enters the room and sits down near the door to attend on the bride.

In the morning a band of tabbâlin, some of whom are playing drums (tabbâlin in the restricted sense of the word) and others (so-called gaiyattin) oboes, come to darr l-örs. When their music is heard at dar islän the bridegroom and all his friends go to join them. They enter the house, the bridegroom sits down in the nuptial chamber on a mattress opposite the door, the gaiyattin also seat themselves inside the room near the door, while the tabbâlin remain standing in the centre of the house. The musicians with their music ișábbhư al lă- 'rîs, that is, wish a good morning to the bridegroom. While they are playing all the men, including the bridegroom, pay a fee to the band by placing silver coins on the forehead of the chief of the gaiyattin, after which the musicians go away and the bridegroom and his friends return to dãr islän. But about eight o'clock the gellâsa comes to fetch him for his breakfast, which he has together with the bride in the däḩ̌ûsa; his friends, on the other hand, are served with breakfast in dār islän, and thither he returns himself after a while. On the morning of this day, which is called nhar s-sbah, "the day of the morning," he no longer has his face covered.

It should be added that if he has had intercourse during the night-which is by no means always the 
case-he goes in the early morning to the hot bath, accompanied by his friends from dar islän; and on his way back he buys a large quantity of fakky (dried fruit), fills a taifor with it, and sends it, covered up with a $m k e b$, to the house of the bride's parents, distributing the rest of the fakya to the bride and htattar in his own house. The frkya indicates that the bride was a virgin. A nggâfa takes her drawers, folds them so as to show the blood, and ties them up in a sebnîya, or silk kerchief, with golden embroidery; she then carries the bundle on the top of her head to the middle of the house, where she puts it down on a cushion near the door of the nuptial chamber, and opens it so that the blood becomes visible. A quivering noise is made by all the women present, who one after the other put money on the top of the drawers. When this ceremony, which is called s-sarwal, "the drawers," is finished, the money is removed and kept by the ngâgef as their fee, the drawers are again tied up, and the $n g g \hat{a} f a$, accompanied by other ngâgef, carries the bundle on the top of her head to the house of the bride's family, where her female relatives are still assembled. When the ngâgef arrive at the door of the house they make a quivering noise to advertise the event, though their arrival was foreboded by the fakkya sent in advance. After they have been entertained with tea and food, they exhibit the drawers on a cushion placed in the middle of the house, all the women make a quivering noise, and the htattar put money on the top of the drawers. The ngâgef then return to dar l-yrs, leaving the drawers 
behind to be washed with other clothes, and the htattar go away for good, the feast in the house of the bride's family having now come to an end. As already indicated, these ceremonies with the drawers do not necessarily take place on the day after the bride was fetched, but on the day after the first intercourse and the appearance of hymeneal blood, and the htattar remain in the house of the bride's parents till the drawers are sent there, but only if they appear within seven days; after the lapse of this period the htâtar go away in any case.

If the bride is found not to be a virgin the wedding may come to a sudden end, the sdaq being returned, as also the clothing which the young man sent to his fiancée. But it may also happen that the bride's parents, in order to avoid a scandal, bribe the bridegroom to conceal the fact for the present, in which case the blood of a fowl or pigeon is used as a substitute for the lacking signs of virginity. If the bridegroom accuses the bride of not being a virgin, her parents send an aunt of hers to ask her if the accusation is true. If she denies it and her parents believe her, they send two qwậbel, or professional midwives, and two 'ădull, or notaries, to the bridegroom's house, the former to examine the bride and the latter to write down the result. If the bridegroom was wrong her parents accuse him before the governor, who orders him to be flogged and put into prison, and in former days he was besides taken about in the streets of the town with his hands tied behind his back. When he then comes out of prison and breaks the hymen of his wife, a nggâf $f$, 
accompanied by male musicians, takes the blood-stained drawers on her head to the house of the wife's family, where a feast is celebrated on this occasion.

In his description of a wedding at Fez four hundred years ago Leo Africanus gives the following account of. the meeting of bride and bridegroom :

" The father, brother, and vncle of the bride lead her vnto the chamber-doore, and there deliver her with one consent vnto the mother of the bridegroome: who, as soon as she is entered, toucheth her foote with his, and foorthwith they depart into a generall roome by themselues. In the meane season the banket is comming foorth : and a certaine woman standeth before the bride-chamber doore, expecting till the bridegroome hauing defloured his bride reacheth her a napkin stained with blood, which napkin she carrieth incontinent and sheweth to the guestes, proclaiming with a lowd voice, that the bride was euer till that time a vnspotted and pure virgine. This woman together with other women her companions, first the parents of the bridegroome and then of the bride doe honourably entertaine. But if the bride be found not to be a virgine, the mariage is made frustrate, and she with great disgrace is turned home to her parents." 1

In Andjra, after the bridegroom and wazâra have performed their evening prayer, the latter take him to the room where the bride is waiting. They all get up and walk with flags and candles to the door of the room. The hâjeb, or best-man, calls for the bridegroom's parents, who come out, the mother still carrying the bundle of clothes on her back. He tells the bridegroom to kiss their heads. The mother puts down the bundle, containing her son's shaved-off

1 Leo Africanus, The History and Description of Africa, ii. (London, 1896), p. 450. 
hair, and asks the hâjeb to tell him to step three times over it; this is done in order to prevent the working of magic on him by any one who may have got hold of some hairs when he was shaved. The hajjeb says to the parents :-Árḍu "ála wîlldkum, "Bless your son." $\mathrm{He}$ then throws the carpet, cushion, and flags into the room through the doorway, which is only closed by a curtain:

The bridegroom enters the room, which is lighted up with four candles, and shuts the door behind him ; but he must take care not to turn his head back, as otherwise evil spirits may enter with him. He takes off his hâyệk, turns his face towards the East, and says a prayer. He eats of the food, consisting of two chickens, eggs, thin cakes of bread called rgaif, and dried fruit, which was brought from the bride's house and placed by her haddáy $\mathrm{He}$ addresses the bride, who is sitting behind a curtain, with the words :- $\bar{A}$ dik lulîya, lâzem tsâkul m'âya, "O lady, you must eat with me." As she gives no answer he pulls back the curtain and sees his bride, perhaps for the first time in his life. He puts into her mouth a piece of rgaif, which she eats with downcast eyes. $\mathrm{He}$ then puts into her mouth a date with the stone removed, a raisin, a small piece of fowl, a piece of a walnut, a piece of a fig, and a small piece of an egg. He takes a new bottle filled with water and a new bowl, brought there among other articles from the bride's house, goes to the four corners of the room and sprinkles a little water in each corner, takes hold of the 
bride's hands, first one and then the other, and dips the tips of her fingers into the water which he has poured out into the bowl. He drinks from the bowl and then holds it for the bride to drink from; it is necessary that he should drink first, in order to become her master. Touching her temples with the thumb and middle finger of his right hand he recites the "sûra of the dinn," and, still keeping his hand in the same position, adds some words like these :- "O lady, may God bless you and me and our house, may he give us children, and may he give us peace, and may he give us herds and flocks; there is no god but God, and Muhammed is the Prophet of God." 'He undresses himself completely, takes hold of the bride, and removes her clothes. He has to untie seven knots made by her hadddyin in the cord ( $\left.t_{1}^{s} e k k a\right)$ of her drawers; should he omit doing so, he would have to pay a fine to them.

Before he has intercourse with the bride he puts his own and her slippers under her in the bed to serve as evidence of her virginity. Should no blood appear he would at once go and tell his mother about it, and the bride would be sent back to her parents; but let us assume that she is a virgin. The slippers are removed from the bed and the bride is left there to sleep. The

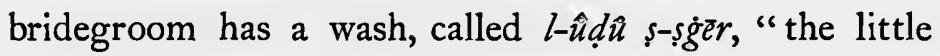
ablution," dresses, prays, and then has a short sleep on the ground. After awakening he has a second wash, l-vidu l-kbir, "the great ablution," sits down, and recites a sura of the Koran. At daybreak some of the 
wazâra knock at the door asking him to make himself ready. The bride's haddáy night in a neighbouring room, tell them to wait a little, enter the room of the young couple, examine their slippers, make a quivering noise, and kiss the bridegroom's head, congratulating him with the usual phrase, Hnîya 'álik. When the wazâra hear the quivering noise they fire off some shots. The haddáy̆n take out to them four palmetto trays (ǵrâbel, sing. gárbäll), filled respectively with rgaif, ordinary bread, raisins and walnuts, and figs and dates, all of which have been sent by the bride's family. The wazâra knock once more at the door, informing the bridegroom that they are ready. He comes out well covered up and with his eyes painted with antimony, after which the haddayzn again enter the room and receive the money which he has put in one of the bride's slippers as a present for them.

He now goes to the mosque with the wazâra, who are carrying the trays given to them by the haddayin. He is received by the $f q \bar{\imath}$, who kisses him on the head, saying, Hnîya "ălik, "My congratulation to you"; and the same is done by the wazâra, who address him sîdna, " our lord." The "árab also come one by one and kiss him on the head, saying, Hnîya 'álik a s-súltan, "My congratulation to you, O Sultan "; but they have only been allowed to enter after they have had their hands tied behind their backs. They then leave the room but enter once more and this time all together, with their hands untied, for the purpose of robbing the Sultan of 
his slippers and turban and other articles of his dress and carrying away the flags. A struggle commences between them and the wazâra; if the latter are victorious the 'arab are tied and punished with sticks before the Sultan, and are only set free after they have asked for pardon. The wazâra, the $f q \tau$ and schoolboys, and the 'arab sit down and eat in three separate groups, whereas the Sultan partakes of nothing, sitting silent with downcast eyes. One of the wazâra brings a pail of water, and, after an ablution, the Sultan and others say the dha prayer.

Meanwhile the musicians strike up a morning serenade at the bridegroom's house, where the bride is sitting with her haddaym and other women of her family. The bridegroom and the wazâra go there and sit down on a carpet in the yard. The hajjeb comes and distributes silver coins to them, a peseta to the Sultan and a bulyun to each of the wazâra-money which was all previously handed to him by the Sultan. The latter gets up and gives his coin to one of the musicians, and the wazâra follow his example; this is l-ğrâma del-ǵaiyâda, after which follows l-grâma deșsúltan, the men from among the young couple's relatives presenting the bridegroom with silver money, varying from a bilyun to a few dollars. At this ceremony there is nobody who cries out the donor's name and the sum given by him, as the bridegroom now himself can see everything going on. One of the bride's hadday̌n comes out with a fine towel ( $f \hat{u} t a$ ) worth about a dollar, and hangs it on the shoulder of the 
chief of the tabbata; this is the bride's present to the musicians, who afterwards sell it and divide the money between themselves. The haddayın then bring palmetto trays filled with various kinds of food from the bride's trunk and give one tray to the musicians, four to the Sultan and his wazâra, one to the schoolboys, and three to the 'arab. The musicians take their food to their room, the Sultan and wazâra go with theirs to the mosque, and the schoolboys and 'arab eat theirs in the yard.

Among the Tsal, when the bride hears the bridegroom coming, she takes her right slipper in her hand and waves it seven times towards the door, in order that she shall rule over him. When he enters he cuts the rope supporting the curtain which hides the bride, and goes, without saying a word, to the bed where she is sitting. She kisses his hand. He removes the cover from her head, crushes its cane-work and throws it on the floor, thus destroying the bas, and taps her seven times on her head with the flat of his sword, so as to become her master. Only then does he begin to speak to her, and burns various kinds of incense to drive away evil spirits. If she makes resistance and he is not strong enough to overcome her, he calls for his $u z \hat{i}$, or best-man, who is standing outside the door, ready to step in and help him by tying the bride's wrists together or her arms to her legs. When the bridegroom is resting his head on her arm she may, if she is in love with him, say to herself in an inaudible 
voice :-Farrást lek l-hăbár u gatțittek be l-hăbár, drúmni má ram l-mîyęts l-qbar; qáulet allàh u qáulets $r$-rsúl $u$ qáulets lşlla Fațima bents l-mkün jebbâdèts s-shọor men sébe $a$ bhorr, "I have made you a bed with [my] flesh and I have covered you with [my] flesh, may you be fond of me as the dead is fond of his grave; the speech of God and the speech of the Prophet and the speech of Lady Fatîma, the daughter of the [holy] places, who took charms from seven seas."

When the bridegroom leaves the room the $u z \hat{i} r$ fires two shots, and the women of the village assemble there. If they find blood on the bride's chemise (manșorîya), which is on this occasion styled sárwal, "drawers," they make a quivering noise and dance in the room, the bride's sister with the chemise on the top of her head. It is then hung up in the yard so that all the people shall see the marks of virginity. Should there be no such marks the bridegroom's family would exclaim, Ddi kélbt"ak 'aliya, "Take away from me your bitch" ; and the bride's father or, in his absence, her brother would shoot her dead in the room or in the yard, besides which all the money and presents given would be returned. But it very rarely happens that a bride is found not to be a virgin. In the morning the bride's mother sends to the bridegroom's family a dish of sěksu and meat, called $l-g d s^{\prime} a$ dess-sváh, " the dish of the morning," to be eaten by them alone.

In the Hiaina the bridegroom, accompanied by the islan, goes to the door of the house in which the bride 
is waiting. He is there left alone by his friends, and enters the house. He cuts with his sword the rope which has been tied from wall to wall in front of the bed; this is to cut off the bas. He gently slaps the bride on her forehead and shoulders with the flat of his sword, so as to expel evil spirits. He takes off her right slipper, removes the needle which her mother has put into it as a protection against $j n \bar{u} n$, and throws it away, at the same time throwing away the bas, and then puts the slipper back on her foot. He plaits the hair on the right side of her head, opens her manșorîya or qáftan, takes hold of her, and pulls her up to stand. She now removes his slippers; there was said to be some magic in this, perhaps the bridegroom thereby hopes to become master. He gives her some money, which is called hállän lä-hzậm, "the opening of the girdle"; but this is only a figurative expression as she has no girdle on her. They partake of some figs and búsiyar from the mézwud brought from the bride's house, and some incense is burned as a safeguard against $j n \bar{u} n$. I was told that, if the bride remains long alone before the bridegroom enters the room so that she dozes and is then awakened and frightened by the noise he makes, she may be struck by $j n \bar{u} n$ and get a distorted face or lose her senses.

When the bridegroom is gone, his and the bride's mother, together with other women, enter the room and make a quivering noise when they see the stains of blood, whilst the men outside fire off their guns. The mézwud is taken out of the room and the islan 
have a fight about it with the unmarried women, the victorious party eating its contents. The bride's mother entertains the people with tăâm (séksu). This morning is called sbah búsiygar, "the morning of búsiyạr."

Among the Ulåd Bu-Àzîz, the bridegroom, after being smeared with henna, quietly goes behind the curtain in the tent where the bride is sitting, and takes her with him to a nwạla, or straw-hut, to have connection with her, or, in default of a straw-hut, has connection with her in the tent or on the waste land outside the village; but in any case they part before daybreak. As we have noticed, however, they already had intercourse the previous evening with ceremonies similar to those which in other tribes take place at the meeting of the bride and bridegroom after she has been brought to her new home.

In the morning men of the bride's village kill the fowls sent the day before by her mother, while the women from her village make bưsiyär of flour from the wheat belonging to the $d h \bar{a} z$, together with salt butter. These cakes, thin like wafers, are torn into pieces, the gravy of the boiled chickens and melted butter are poured over them, onions are added, and then chickens are laid on the top. This dish, which is called rệsa, is served about midday, and is partaken of by the people from both the bride's and bridegroom's villages, the men having their meal in the mosque or in a large tent, and the women 
afterwards in the bridegroom's tent. After finishing this meal, which is called lè-mmúdda dyält l-mra (" the time of the woman"), all the men put some money in the empty dish, the bachelors giving more than the married men, and the bridegroom taking the lead with the most liberal gift - a dollar or two; he also partook of the meal, with the hood of his cloak drawn over his face. Fâtha is made, and the men with the exception of the bridegroom and his unmarried friends go away. The money just referred to is taken by the mother of the bride.

Among the Ait Sádden the bride and bridegroom meet some time in the night between the hour for the evening prayer and daybreak. When one of them has arrived in the room, the imsnein go and fetch the other partner and remain themselves outside the entrance with the door shut, if there is a door, ready to come in and tie up the bride in case she makes difficulties and the bridegroom calls for them. Before the connection the bridegroom gives to the bride a small sum of money, from half-a-dollar to two dollars, which is called tiruyi $n-\dot{u} h a z z a m$, corresponding to the Arabic hăllan lä-ḩzâm. He removes the sword which he is carrying, but both he and the bride keep on their slippers not only that night but for seven days and nights.

Very early in the morning, before sunrise, the bride's chemise is exhibited on the roof of the house by her mother or sister or the bridegroom's mother. 
There is always blood on it, because, if the bridegroom suspects his bride of not being a virgin, or from his own experience knows that she is not so, he has a cock ready to kill, and then, if necessary, smears her chemise with its blood; I was told that it never happens that a bride is sent away on account of lost virginity. A man of the bridegroom's household or some bachelor fires off his gun once outside the house, and the bridegroom's mother or some other woman of his family makes three tiğ̛̆ratin. The women and other people, who assemble outside the house, take down the chemise from the roof, put it in the yard or inside the tent, and sing and dance round it, the men playing on tambourines. The dancing women are then entertained with breakfast consisting

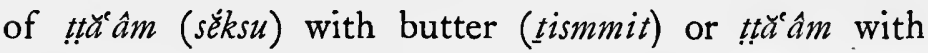
meat. This breakfast is called ssbah $n$-tslit, "the morning of the bride."

Among the Ait Yúsi the bride late in the evening walks with the imsnein from the tent where she has been sitting, either to another tent or to a lonely spot outside the village to meet the bridegroom. Here also the imsnein assist the latter, if he is in need of help, and subsequently take the bride back to the tent from which they came. There they and the bride together partake of a dish called $u^{\prime} g^{y} n u$, which consists of roasted wheat, pounded and mixed with melted butter. This dish, which has been prepared by the bridegroom's mother, is eaten by them under 
the cover of a woman's mantle (taheddunt), and the same spoon is used by the bride and the imsnein, who may be as many as four, although in the case of a poor man's wedding there may be a single amsnäi only.

It may also be, however, that the couple do not meet at all on the night after the bride's arrival. Next day in the afternoon the bridegroom and imsnein have a meal together off the so-called lechdit $\underline{t} n$-tslit, "the present of the bride," consisting of meat and dates, which, covered up with a kerchief belonging to the bride, are taken to them on a palmetto tray (amidun) by a procession of men and women amid singing, playing, and dancing. When the bridegroom and imsnein have finished their meal, they put some lgrama on the tray and send it back. The imsnein then go away, and another man, of the bridegroom's family, takes the bride to some place outside the village, where she meets her spouse; this distant place is chosen in order that the voice of the bride shall not be heard in case she makes a noise. On this occasion the bridegroom pays her a small sum of money, half-a-dollar or less, which is called táruyi unazzam, "the opening of the girdle." After they have had connection she goes back to the tent to spend the rest of the night alone.

The morning after the intercourse a woman who is an expert dancer takes the chemise of the bride stained with blood (the bride's or that of a fowl), puts it on her head, and dances with it before the people of the village, who also begin to dance and sing. The 
bridegroom's family entertain all the villagers with ahrir, or porridge made of wheaten meal, which is served and eaten with salt butter; and while eating they smear some of it on each other's faces. The same day the bride paints herself with antimony and walnut root; at the $t a g^{y}$ rurt she was painted with henna only, whereas the bridegroom on the day when she was fetched, before her arrival, not only had his hands painted with henna but also his eyes with antimony and his lips with walnut root. It may be added that the bridegroom carries neither sword nor dagger.

Among the Ait Nderr the bridegroom enters stealthily the place where the bride is waiting, kicks her lightly, so as to become her ruler, and puts his sword on the bed. If the bride makes resistance and the bridegroom cannot manage her, he calls in his "vizier," who is standing outside ready to come in and tie up her hands. Before they part he makes her a present of a dollar or two out of the money which he received when he was painted with henna; this present is called lfus n-ssbah, " the moneylof the morning" or "hymeneal blood" (the word ssbah, "morning," being used to denote such blood). When he goes out, the vizier fires off his gun once or twice at the entrance, and they both retire to the tent from which they came. When the shot is heard the women of the village come and examine the bride's clothes, and if there are stains of blood on them one or two of the women make a quivering noise. Later in the morning they paint 
with saffron a line on the bride's forehead and along her nose and spots on her cheeks. As for the stains of blood, it does not matter whether they are genuine or come from a cock killed for the purpose of disguising lost virginity, or even if they are altogether wanting. Among the Ait Ndēr, as well as among other Brâber, the girls are not noted for their chastity, and it is common for a young man to have intercourse with his fiancée even in her father's tent; hence the absence of the marks of virginity in a bride is interpreted as an indication that the bridegroom has previously had intercourse with her, and it is no disgrace for him to keep her. Indeed, it may happen that she is already with child or even a mother at the wedding. Only in rare cases is she sent away, and then she leaves the bridegroom's tent no longer dressed in her bridal costume but in the mat which her father gave her, and both the tämamt and ssdaq paid for her must be returned.

When the bride's mother hears the quivering noise she gets up and makes bread of the flour which she brought with her, being assisted in her work by the women of the tent. With this bread and the butter and dried fruit which she also took with her she entertains the people who now come and salute and congratulate her, and receives money from them in return. This money she gives to her daughter, and goes back home.

Among the Ait Warain, at the moment when the 
CHAP.

bridegroom enters the room or tent, the bride, if she is acquainted with the proper custom and does not feel shy, throws at him one of her slippers in order to get power over him; on the other hand, if she refrains from doing so, he taps her three times on the head or shoulder with his sword, so as to become her master. He hangs his sword on the wall over her head, as a safeguard against jnūn. They partake together of a dish of bdzin, that is, sekksu made of small lumps of flour with milk and salt butter. The bridegroom burns some gum-benjamin (jâwi mekkáwi) " to please the spirits of the place," and while this is being done the couple refrain from speaking for fear of the spirits, who are then supposed to be about. He performs an ablution and says two rekiat, after which he makes fâtha, asking God to bless him with good children; this ceremony is considered so necessary for the production of good offspring that, even though he has never prayed before, he has to learn it for this occasion. Just before he lies down with the bride he gives her a dollar; there is good luck in this

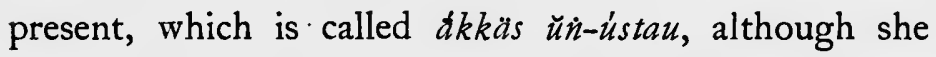
has no belt (astau) on her. If she makes resistance he calls for the $l u z \hat{i} r$, who is standing outside the door of the room or tent, ready to enter and tie the bride's hands to her legs; indeed, it seems to be the custom that she should be obstinate on this occasion.

Later on in the morning, after the young couple have had connection, they eat together some tarffist, that is, bread-crumbs kneaded with salt butter; and 
it is considered necessary that the bachelors also should subsequently have a share of this dish owing to its baraka. When the bridegroom leaves the bride, the luzîr comes in again and fires off his gun, after which he goes out, loads it afresh, enters, and fires a second shot. The object of this ceremony was expressly said to shoot the bas, and the shots are two in order to destroy the bas of both the bride and bridegroom. The bridegroom and luzîr then go together to the bachelors' room or tent, whilst the bridegroom's mother and a maternal aunt of the bride enter the nuptial apartment and make there a quivering noise. The former places a flag attached to a bamboo cane on the roof of the house or tent, and hangs on the wall the drawers of the bride to flutter in the air ; among the Ait Warain drawers are worn by women on this occasion only. The flag and the drawers, however, are only left there for a little while to serve as an advertisement of the bride's virginity; one of the bachelors soon blows the flag to pieces by a shot from his gun, and two other bachelors do the same with the drawers-a ceremony which was said to destroy the bas. The bride's mother then brings a dish of setksu to the yard, where a fight ensues between the bachelors and the women, married and unmarried, who hurl at each other stones, earth, slippers, and anything to hand; nay, the defeated party still try to prevent the victors from eating the food by throwing into it the fresh dung of animals. This fight was said to have a beneficial effect. The drawers of the bride are of course only exhibited if 
there are stains of blood on them, but here also the blood may be that of a cock. Among the Ait Warain, as among the Ait Nderer, it is very common for a man to have connection with his future wife before marriage, and in such a case she often makes him solemnly promise to marry her. If the bridegroom unexpectedly finds that the bride is not a virgin, he may send her away dressed in an old piece of tent-cloth, or he may keep her on condition that her father returns to him half of the ssdaq, but then the father would compel him to swear that he has had no connection with her before the wedding. It may be added that also the bride herself advertises her virginity by dabbing a small spot of blood on either cheek, though even that may be the blood of a cock.

The same morning the luzîr, with the assistance of some other men, distribute among the people present the tûrift which was brought the day before from the bride's home, and which is considered to contain much baraka. Among the Ait Hăssan, a division of the Ait Waráin, the following ceremony also takes place on this morning. The bride's mother, who then comes to the bridegroom's place, is asked by the bachelors to give them lfțor né-ssérwal, "the breakfast of the drawers." When she replies that she has nothing to give them, they seize hold of her and put her into a trittsa, that is, a net made of rope for the purpose of carrying straw. This net, with the woman in it, is hung up inside the house, with one end attached to the wall and the other end to the tatrkizt, or pole supporting 
the centre of the roof. She is then swung to and fro with such force that she is knocked against the wall, and this is continued until the bachelors get what they have asked of her. Custom requires that she should first refuse their request, so that they get a reason for putting her into the tráttsa. For the ceremony in question has magical significance : it is parallel to the bridegroom's mother carrying a sieve or a bundle of clothes on her back as if it were a baby. In this tribe, as elsewhere, rocking is a common method of putting a baby to sleep, and a tráttsa is sometimes used for the purpose.

We have still to notice an interesting ceremony which takes place the same morning among the Ait Warain. The bride, whose hair was untied the day when she was painted with henna, now has the left side of it plaited by the bridegroom, but only after the ribbon (dzellum) with which it is fastened has been subjected to the following procedure. It is put by the women into a bowl of henna, from which the bachelors try to take it; formed in a ring round the bowl, the women oppose them, and a fight ensues. If the bachelors win, the bride has to give them food, of which the women also partake, though by themselves, whereas, if they lose, the women are entertained with a meal of which the bachelors get nothing. The condition of the izellum after the fight is taken for an omen: if it is untorn, the wife will always remain with her husband, and their marriage will be happy; if it is a little torn, they will separate after some time; and if it is much 
torn, there will be speedy separation. The bridegroom's father is the first to examine the dzellum, and seems to take the matter quite seriously. The bride hands it to the bridegroom on the evening when they meet again, and after plaiting her hair he gives her some money.

Among the At Ubahthti the bridegroom visits the bride late at night, when the people in the tent have gone to sleep and the light has been extinguished. But he does not enter the enclosure alone: he is accompanied by his auzir, who lights a candle, which is then left burning till he leaves. He puts his pistol underneath the pillow, and taps the bride with his right slipper seven times between her shoulders. If she is obstinate the áuzir ties up her hands, and if she makes serious difficulties and becomes noisy, she may even be beaten by both of them. But whether she offers resistance or not, the duzir remains in the enclosure as long as the bridegroom, only turning his back to the couple when they have intercourse. He talks and jokes with them and congratulates and blesses them; nay, he even laughingly proposes that he also should have his share of pleasure with the bride. After the connection the bridegroom gives her the so-called șbah, consisting of about half of the money received at the henna-ceremony.

If no blood is found on the bride's lizar, the auzir goes and reports the fact to the bridegroom's mother, who gives him some blood of a cock to sprinkle on it. 
It is not the custom for a bride to be sent away because there are no signs of blood, and yet it is not usual for a man and woman to have intercourse with each other before their wedding. Before the bridegroom and áuzir depart, the latter ties the belt of the bride round the hâyẹk over the crown of the bridegroom's head, where it is left as long as the bride remains ungirdled. When the two men have left the tent some of the islän fire two or three shots, and the woman attending the bride makes a quivering noise. The lizar of the bride is exhibited on the roof of the tent, so that the people shall see the blood, but is then again used the following nights, without being washed until seven days have passed. On the morning after the first intercourse the bride's mother gives breakfast to the bridegroom and bachelors in the tent where they are sitting, and afterwards also to the bridegroom's family and the women who are with the bride. This meal, which is called șbah n-trinttot t, " the woman's morning," consists of figs, dates, raisins, and thin cakes made of flour and salt butter (țǐarqut ), and all who partake of the meal put some money in an empty dish ( $d z z e ̂ ́ w a)$ as a present to the mother, who, however, divides it with her daughter if she is sufficiently fond of her.

Among the Ait Wäryâgäl the bridegroom has his first intercourse with the bride only on the day after her arrival, when all the guests have gone away, and if he is shy of his parents he waits till the evening before he goes to see her. When he enters the room where 
she is sitting he has his head covered and must not look back. He goes to the bed and beats her with the cord (firu) of his dagger (d dihadmit) three times between her shoulders, so as to make her obedient to him. He gives her his right hand as a greeting, and puts into hers a silver coin which he has between his fingers ; this money is called rfrus nec-ssram, " the money of greeting," and its object was said to be to make the family prosperous. He performs the usual ablution preparatory to prayer and says two rek'at, after which he makes fâtha and says, S-slâmu 'álikum, "Peace be with you." He pushes back the hood of his cloak, she removes the shawl from her head, and they have together a' meal consisting of bread, eggs, raisins, almonds, and walnuts. He seizes hold of her; she makes resistance and cries, but regardless of this he has intercourse with her. They spend together the rest of the day, as also the night, the bridegroom only leaving the room early the following morning with his head covered as before. His mother and the other women of his family come there and examine the chemise which was underneath the bride on the bed. The latter now puts on her forehead the didli mentioned before, and dresses herself in fine clothes; unless, indeed, she is found not to have been a virgin. In this case she is sent back to her father, who kills her either by shooting or poisoning; but such cases are very rare.

In Aglu, also, the bridegroom pays the first visit to his bride on the day after she was taken to his house. 
Before he enters the room where she is waiting for him, he sends there the luzira with his sword, which she puts on the bed; from the day when the bride is fetched, and as long as the wedding lasts, he carries a sword. In the evening he goes there himself accompanied by his luzîr, but enters alone. He first places his right foot twice over the threshold and makes his entrance by a third step. He throws at the bride his right slipper, into which he has put some salt, and she then throws at him her right slipper likewise containing some salt. He says two rek'at and proceeds to the bed. The luzîra brings a dish of meat, a dish of séksu, and a third dish containing bread, honey, and salt butter. From each of these dishes the bridegroom pushes a little food three times into the mouth of the bride, who bashfully tries to prevent it, and she then does the same to him. After this he gives her a small sum of money, called lfüs n-ssêrwal, " the money of the drawers," and dates. The money generally has an appeasing effect on the bride, who first makes resistance, sometimes even scratching the bridegroom's face so that blood flows. If he succeeds in breaking her hymen, he leaves the room with the backs of his slippers pulled up, fires off his gun, and goes with the luzîr to the mosque after performing the necessary ablution. The shot is a signal which attracts to the room men and women, who come to examine the blood-stained lizar ; they partake of the food left in the dishes, and the bride gives to all of them dates to eat. There is dancing that morning, in which the bridegroom takes part in case he has 
deprived the bride of her virginity. If she is found not to be a virgin she is sent away; and sometimes she is killed by her father or brother, or given in marriage to some man living in a distant place, so that nothing may be heard of her for the future.

It may be added that the candle or candles burning in the room when the young couple have their first intercourse must not be extinguished by anybody, but must be left to burn out-a custom which also prevails at Marrakesh and Mogador. ${ }^{1}$ In some parts of Sus, though not in Aglu, and among the Shlöh of Demnat as well, it is the custom that, when the bridegroom is going to have connection with the bride, the latter takes one of her new slippers and beats him three times with it on his body; it is believed that if he keeps perfectly silent he will be the ruler of the house, whereas in the opposite case he will be ruled over by his wife.

Among the Ait Támeldu the bride is in the evening of the day after her arrival subject to the ceremony called afssai $n$-ihf, "the loosening of the hair" (lit. " head "), that is, her hair, which has been tied up with a knot behind, is now loosened, combed, smeared with henna, and arranged in the fashion of married women. The next evening is the $\ddot{u} d \underline{d} \tilde{e}$-lhdunna, of which it has been spoken before; and the third night after the bride was taken to the bridegroom's house or, if his parents are alive, only when all the guests have gone

1 Cf. Plutarch, Quaestiones Romanae, 75 :-“"Why did they (that is, the Romans) not extinguish a candle, but suffer it to burn out of its own accord?" 
away, he has his first intercourse with her. Before he opens her belt (tákŭst) he gives her the so-called áfssai $n$-tákŭst, consisting of a small sum of money-a few pesetas or a couple of dollars. If he finds her a virgin, he fires a shot through the window of the room, and the women outside make a quivering noise (táugritt). In the opposite case he removes his white cloak and puts on a black one, and thus dressed walks out through the crowd of people. The guests then disperse, and the bride is taken back to her old home.

Among the Igliwa the bridegroom visits the bride in the evening of the day when she arrives at his house. The woman who attends her brings some meat, bread, and dates, of which she first gives a little to the bridegroom to put into the mouth of the bride and then a little to the bride to put into the mouth of the bridegroom. This ceremony may be repeated two or three times. The bride does not speak a word but appears bashful, and when the woman has gone away and the bridegroom undresses the bride, it often happens that she makes resistance. If he finds her a virgin he pulls up the backs of his slippers and walks thus out of the room together with the bride; and if he is not a scribe or man of distinction he joins in the dancing which is going on in the same or a neighbouring house or in the yard. So also the bride joins in the dance for a little while, after which she returns with the bridegroom to their room, where they finish the food brought by the woman ; the bride's bashful- 
ness only lasted as long as she remained a virgin. In the morning the bridegroom receives lgrâma from the people, who put down their coins on a tray (iš̆ggi) close to the spot where he is sitting with covered eyes. When giving their money the donors say, "This is on behalf of myself," or, "This is on behalf of my family," or some similar phrase.

If the bride is found not to be a virgin, she is beaten by the bridegroom, sent away in ragged clothes, and sometimes killed by her cousin or brother.

At Amzmüz, if the bridegroom finds the bride to be a virgin, he goes out with the backs of his slippers pulled up as an indication of her virginity, and the blood-stained garment is shown to the people. In the opposite case he beats her and sends her away dressed in black and dirty clothes.

Among the customs described in this chapter we have first to notice those preceding the bridegroom's intercourse with his bride.

Many of them serve the purpose of protecting him or her or both of them from the dangers of which the atmosphere is full when he enters the room or tent where she is waiting for him. He must not let her wait so long that she falls asleep, lest she should be struck by jnün when she is awakened by the noise he makes. ${ }^{1}$ He puts his right foot twice over the

1 The Moors believe that a person seized with sudden fear is peculiarly liable to the attacks of $j n \bar{u} n$, and that it therefore is dangerous to be awakened out of sleep too suddenly (Westermarck, 'The Nature of the Arab Ginn, illustrated by the Present Beliefs of the People of Morocco,' in Fournal of the Anthropological Institute, xxix. [1900], p. 254). 
threshold before he makes his entrance by a third step. ${ }^{1}$ He must not look back, lest evil spirits should enter with him. ${ }^{2}$ To drive away such spirits or other evil influences, he sends his sword in advance to be put on the bed, or puts it there himself, or hangs it on the wall, or lays a pistol underneath the pillow; and he burns incense in silence, sprinkles water in each corner of the room, dips the bride's fingers into water, ${ }^{3}$ and recites over her "the sûra of the dinn." For a similar reason, I presume, he, after an ablution, says two rek'at, ${ }^{4}$ or forms of prayer, which is considered to be essential for the production of good offspring; even in ordinary married life it is held necessary that the husband before having intercourse with his wife should say bismilláh, "In the name of God," lest the devil should enter the

1 Among the Touareg of the Ahaggar, when the bridegroom has been taken to the tent by his friends and has walked round it three times, "il y pénètre ensuite en ayant soin de poser le pied droit le premier, toujours parce que cela porte bonheur" (Benhazera, Six mois chez les Touareg du Ahaggar [Alger, 1908], p. 16). Among certain Algerian Kabyles, when the bride has arrived at the bridegroom's house, she puts her right foot on the threshold of the door, and is then carried in by the bridegroom (Féraud, 'Mœurs et coutumes kabiles,' in Revue Africaine, vi. [1862], p. 43I). In a mosque a Muhammedan always puts his right foot first as he passes into the square devoted to prayer (Hughes, $A$ Dictionary of Islam [London, 1896], p. 329). In ancient India it was considered essential that in crossing the threshold the bride and bridegroom should do so right foot foremost (Winternitz, 'Das altindische Hochzeitsrituell,' in Denkschriften der kaiserlichen Akademie der Wissenschaften, Philosophisch-historische Classe, x1. [Wien, 1892], p. 72). A similar custom prevails among the Greeks of Turkey and in Albania (Löbel, Hochzeitsbräuche in der Türkei [Amsterdam, 1897], pp. 143, 144, 172). Cf. Crooke, "The Lifting of the Bride,' in Folk-Lore, xiii. (1902), p. 241.

2 See supra, p. 189.

3 In Persia, when the bridegroom has entered the bridal chamber, " $\mathrm{a}$ basin and ewer and water are . . . brought, and the right leg of the bride and the left leg of the bridegroom are placed together and washed, and their hands also in the same manner" (Customs and Manners of the Women of Persia, trans. by Atkinson [London, $1832]$, p. 43).

${ }^{4}$ Cf. Lane, Manners and Customs of the Modern Egpptians, i. (London, 1871), p. 218. 
woman and make the child a villain. ${ }^{1}$ The bridegroom cuts off the bas by cutting a rope which is hanging in front of the bed, throws away the bas by throwing away a needle which has been put into the bride's slipper, and crushes the bas by crushing the cane-work of her headgear. In one case he is said to expel evil spirits by tapping her on her forehead and shoulders with the flat of his sword, whereas in other cases his tapping her three or seven times on her head or shoulder with his sword, or his beating her three times between her shoulders with the cord of his dagger, or his smacking ${ }^{2}$ or kicking her, is represented as a method of making himself her ruler. In one tribe he taps her seven times between her shoulders with his right slipper; in another tribe both of them throw at each other their right slippers containing salt, and this suggests the purpose of mutual purification, since salt is a common charm against $j n \bar{u} n$. But we also hear that the bride throws at the bridegroom one of her slippers in order to get power over him, or that she with the same object in view waves her right slipper seven times towards the door when she hears him coming; and when she beats him three times on his body with her slipper, it is said

1 Cf. El-Buhărr, Saḩ th, lxvii. 66, French translation by Houdas and Marçais, vol. iii. (Paris, 1908), p. 578 :--“D'après Ibn-'Abbâs, le Prophète a dit : 'Eh bien! si l'un de vous, voulant avoir commerce avec sa femme, disait: "Au nom de Dieu. Ô mon Dieu, écarte de moi le démon; écarte le démon du fruit de notre union," et qu'ensuite le Destin ou la Prédestination fît naitre un enfant de ces relations, le démon ne pourrait jamais nuire à cet enfant." "

2 Among the Beni Snus in Algeria, as soon as the bridegroom has entered, "il donne, à celle qui va être sa femme, trois ou quatre coups de poing dans le dos. Quand le jeune honme est mal disposé, il la frappe à lui en laisser le corps tout bleu, mais, de la sorte, la femme craint son mari" (Destaing, Étude sur le dialecte berbère des Beni-Snous [Paris, 1907], p. 289). 
to depend on his behaviour whether he or she will be the ruler. The association between a slipper and domestic rule is so natural that these ceremonies may very well have had from the beginning the meaning which is now ascribed to them by the natives, ${ }^{1}$ but at the same time they may also be methods of purification, as seems to be the case with other slipper-ceremonies mentioned above. ${ }^{2}$ In the Andjra custom of water-

I On the shoe as a "symbol" of power see Sartori, "Der Schuh im Volksglauben,' in Zeitschrift des Vereins firr Volkskunde, iv. (1894), p. 173 sq9.; Goldmann, 'Přemysl-Samo,' in Mitteilungen des Instituts für österreichische Geschichtsforschung, xxx. (1909), p. 33 r sqq.

2 The throwing of shoes is common at weddings. At a Turkish wedding the bridegroom "has to run for his life to the harem under a shower of old shoes; for, according to the Turks, an old slipper thrown after a man is an intallible charm against the evil eye" (Cox, An Introduction to Folk-Lore [London, 1897], p. 18). In his Account of the Isle of Man (vol. ii. [Douglas, 1845], p. 129) Train writes :-"On the bridegroom leaving his house, it was customary to throw an old shoe after him, and in like manner an old shoe after the bride on leaving her home to proceed to church, in order to ensure good luck to each respectively; and, if by stratagem, either of the bride's shoes could be taken off by any spectator on her way from church, it had to be ransomed by the bridegroom." Sartori (in Zeitschrift des Vereins fiir Volkskunde, iv. [1894], p. 153) thinks that the main object of throwing a shoe after bride and bridegroom was to ensure fecundity, and Mr. Hartland (Primitive Paternity, i. [London, 1909], p. 109) seems to be of the same opinion. But Brand says in his Observations on the Popular Antiquities of Great Britain (vol. iii. [London, 1849], p. 168) that it is also "accounted lucky by the vulgar to throw an old shoe after a person when they wish him to succeed in what he is going about." M'Lennan (Studies in Ancient History [London, 1886], p. 14 sq. n. ${ }^{3}$ ) suggested that the English custom of hurling an old shoe after the bridegroom may be a relic of capture, being "a sham assault on the person carrying off the lady"; but whatever else may be said against this explanation, it is disproved by the fact that an old shoe was also thrown after the bride. Equally unsatisfactory is, in my opinion, Samter's suggestion that the hurling of a shoe after the bride and bridegroom in England and elsewhere was originally meant as an offering to dangerous spirits (Samter, 'Hochzeitsbräuche,' Neue Fahrbuicher für das klassische Altertum, xix. (1907), p. 134 sqq.; Idem, Geburt, Hochzeit und Tod [Leipzig \& Berlin, 1911], p. 201 sqq.); in this, as in various other cases, he seems to have exaggerated the influence which the belief in spirits has exercised on the wedding ceremonies and underrated the belief in impersonal magical forces. Zachariae ('Zum altindischen Hochzeitsritual,' in Vienna Oriental Fournal, xvii. [1903], p. 138 ) maintains that the custom in question was in the first place meant to avert evil influences, such as malevolent spirits or the evil eye, and that its connection with the idea of good luck is secondary; and that he, also, thinks 
CHAP.

drinking and the order in which it is performed we have an instance of the idea of mastership being connected with a custom which obviously does not owe its origin to that idea. And it is interesting to notice that at Demnat, where I was told that the bride beats the bridegroom with her slipper, it also occurs, according to the description given by $\mathbf{M}$. Sald Boulifa, that she beats him with a piece of rock-salt. ${ }^{1}$

There are other ceremonies that are probably intended to make the husband ruler over his wife, or at all events symbolise his superiority : she removes the slippers from his feet, she kisses his hand. ${ }^{2}$ But she also tries to make him fond of her by whispering some magical words while he is resting his head on her arm. He, for his part, asks God to bless them with children and make them prosper, and when he gives her his hand he puts into hers a silver coin "to make the family prosperous."

It is a very common custom that the pair partake of some food together before they have intercourse. ${ }^{3}$

of it mainly as a safeguard against spirits, appears from his hesitating, but entirely unfounded, supposition that spirits are afraid of leather (ibid. p. $13^{8} \mathrm{n}^{5}{ }^{5}$ ). See also Goidmann, Beiträge zur Geschichte der germanischen Freilassung durch Wehrhaftmachung (Bresiau, 1904), P. 21 ; Idem, in Mitteilungen des Instituts für osterreichische Geschichtsforschung, xxx. (1909), p. 333.

I SaÏd Boulifa, Textes berbères en dialecte de l'Atlas marocain (Paris, 1908), p. 19.

2 At Cairo, when the veil has been removed from the bride on the bridegroom's entrance in the bed-chamber, she rises and kisses his hands (Burckhardt, Arabic Proverbs [London, 1830], p. 116 sq.).

3 The custom of bride and bridegroom partaking of some food or drink in common is very widely spread. See v. Schroeder, Die Hochzeitsbräuche der Esten und einiger andrer finnisch-ugrischer Volkerschaften, in Vergleichung mit denen der indogermanischen Volker (Berlin, 1888), p. 82 sq9.; Westermarck, The History of Human Marriage (London, 1894), p. 419 sq9.; Sartori, Sitte und Brauch, i. (Leipzig, 1910), p. $73 \mathrm{sq}$. In India, for exampie, the bride and bridegroom eat food from the same dish (Crooke, Things Indian [London, 1906], p. 319). 
Sometimes the bridegroom eats first and then puts some food into the bride's mouth, and sometimes, among the Shlöh, they both push a little food into each other's mouths. All over Morocco eating together is a frequent method of sealing a compact of friendship; it is a form of 'ahd, or covenant, which ultimately derives its binding force from the idea that the parties transfer conditional curses to one another by a material medium -in this case the food,-as appears from the usual saying that the food will repay him. who breaks the contract. ${ }^{1}$ In a previous chapter I mentioned that on the occasion called lă-g்dîya del- ărûsşa a portion of food is sent from the bride's house to the bridegroom, and that this is regarded as 'ahd between the parties. To the same class of ceremonies belongs the bride's and bridegroom's partaking of food in common: it is a means of sealing their union by an act which has naturally been suggested by one of the most prominent features of married life, the husband's sharing of food with his wife. Considering, however, that the eating together takes place before the sexual intercourse, it seems at the same time to serve the object of bringing bride and bridegroom nearer each other previously to the great event by which the union is completed. But sometimes there is a common meal after the intercourse as well as before it, and in one instance, referred to in a previous chapter, ${ }^{2}$ there is an eating ceremony the second night, when the pair partake of the liver of the sheep slaughtered

\footnotetext{
1 Westermarck, ' $L: a ̂ r$, or the Transference of Conditional Curses in Morocco,' in Anthropological Essays presented to E. B. Tylor (Oxford, 1907), p. 373 sq.

2 Supra, p. 101.
} 
at "the great henna" of the bridegroom, as also of the egg which was in the bowl containing the henna. The native explanation of this custom was that the liver is eaten for the purpose of making the parties dear to one another, and the egg to make their future white. ${ }^{1}$

Nearly related to the eating ceremonies there are others referring to dress. We have seen that in Andjra the bridegroom, when he goes to visit the bride, has round him a hâyệk which was previously worn by her on the occasion called " the bride's beginning and tying of the hayẹk." ${ }^{2}$ In another tribe the belt of the bride is tied round the bridegroom's hâyẹ̌k over the crown of his head after they have had intercourse, and at Fez the bride, before they part, gives him two handkerchiefs, one of which he ties round his waist, and a cord which she threads through his trousers. In this connection we should further remember the Hiáina custom, according to which the bridegroom, at his rbet, has on his feet a pair of slippers bought with money out of the bride's share of the $s d a q .^{3} \quad$ These customs remind us of another form of 'ahd, namely, that which consists in an exchange of articles of dress; as I have said in another place, " in times of rebellion chiefs exchange their cloaks or turbans, and it is believed that if any of them should break their covenant he would be punished with some grave misfortune." 4 But we may assume that in the

1 Among the Muhammedans of India some milk in a cup is given to the bridegroom to drink, after which the bride's mouth is touched with the leavings; this is supposed "to create a mutual affection between them" (Jaffur Shurreef, Qanoon-eislam, or the Customs of the Mussulmans of India [Madras, 1863], p. 91).

2 Supra, pp. 127, 128, 142 sq. 3 Supra, p. 102.

* Westermarck, in Anthropological Essays presented to E. B. Tylor, p. 373. 
wedding ceremonies the article of dress belonging to or presented by one of the partners and worn by the other, like the food partaken of in common, is meant not merely to serve as a pledge, but to establish a more intimate union between them.

It is no doubt for a similar purpose that the bridegroom sometimes plaits the hair on one side of the bride's head. Besides the Arabs of the Hiaina and Berbers of the Ait Warain, there are other tribes, such as the Ulâd Bu-Ăzîz and the people of Andjra, in which the bride arrives with her hair dishevelled, and the reason for this custom is avowedly to prevent the bas from accumulating by being tied up. I presume that the ceremonies connected with the plaiting of her hair among the Ait Warain-the putting of the dzellum into henna, the fight over it, and the bridegroom's paying of money to the bride after he has coiffed her ${ }^{1}$-are meant to neutralise the danger with which the act is supposed to be attended. ${ }^{2}$ There are other instances in which the payment of money serves as a prophylactic. When a shereef, or $f q \tau$, or somebody else who is possessed of baraka, tries to cure a sick person by reading an incantation over him and touching his forehead or the affected part of his body with his right hand, the patient must give him a small sum of money, at least a dérham, or, if he has no money, something white, like wool, eggs, buttermilk, salt, or sugar, or some grain. This

1 At Fez, on the fifth day after nhär l'ors, when the bride's hair is opened, the bridegroom undoes the end of one of her plaits and puts on her hair a silver coin (infra, p. 276).

2 The Roman custom of parting the hair of a bride with the point of a spear (Plutarch, 2uaestiones Romanae, 87) may have had a similar origin. 
reward is called le-ftöh ( $l-f t^{5}$ öh), i.e. "the opening," or derham l-ftsyh, or uqiit Y-Y̌ę ; and it is thought that, if it is not given, the illness will affect the doctor. So also I believe that the money, called "the opening of the girdle " or "the money of the drawers," which the bridegroom presents to the bride before the connection, is really intended as a safeguard against evil influences, ${ }^{1}$ although it is in one case said to bring good luck and in another to have an appeasing effect on the bride. ${ }^{2}$ The opening of a woman's belt is considered to involve danger to others even if she is not a bride. In the Hiáina, if a strange woman spends a night as guest in another person's house, she is not allowed to undo her girdle unless a fowl is killed or a cut is made in the ear of a sheep; the blood of the fowl or sheep is then supposed to destroy the bas emanating from her when she loosens her belt. Similarly, among the Ait Warain a married woman, widow, or divorced wife must not open her girdle when she spends the first night in a relative's house or tent, unless an animal or fowl is killed, or a cut is made in the ear of an animal, and the blood is sprinkled on the threshold; and the same rule has to be observed whenever such a woman is guest for a night in the home of a stranger. Among the Ait Ndēr, again, she is under no circumstances allowed to loosen her girdle in another person's tent, and if she stays

1 In ancient India the bridegroom recited certain verses when he opened the girdle of the bride (Haas, 'Die Heirathsgebräuche der alten Inder,' in Weber's Indische Studien, v. [Berlin, 1862], p. $3^{89}$ sq.).

2 The rfrus nę-ssräm, or " money of greeting," which the-Rifian bridegroom gives to the bride for the professed object of making the family prosperous may have had a similar origin. 
there overnight for the first time the host kills a fowl or makes a cut in the ear of a goat, and in the latter case, he, besides, secretly smears a little of the blood on her clothes. In many tribes (Andjra, Tsal, Hiáina, Ait Waráin, etc.) the bride comes to the bridegroom's place without a belt, ${ }^{1}$ and I was expressly told that the object of this custom is to prevent her giving bas to the bridegroom. Now it is true that even in some of these cases he pays money to her before they have intercourse, but considering that this money nevertheless is called "the opening of the girdle," it is a fair conclusion that the payment of it is either a survival from a time when it deserved its name or is a custom borrowed from without. Sometimes money is given by the bridegroom not before but after the connection; in such cases it is looked upon as a pretium virginitatis, but its original object may notwithstanding have been to remove a danger. ${ }^{2}$ At the same time I admit that an idea of compensation may be connected even with the money given before the consummation of the marriage. ${ }^{3}$

1 Also among the Beni Snũs in Algeria (Destaing, op. cit. p. 289).

2 In Dukkâla it is called hällän l-hạ̣ậ̣m, though given after the connection.

3 At Cairo the bridegroom must give to the bride a present of money, which is called "the price of the uncovering of the face," before he attempts to remove the shawl which she has thrown over her head; on removing the covering, which she does not allow him to do without some apparent reluctance, if not violent resistance, he says, "In the name of God, the Compassionate, the Merciful "- a phrase which almost suggests the idea of the act being attended with supernatural danger (Lane, Manners and Customs of the Modern Egyptians [London, 1896], p. 182;Idem, Arabian Socicty in the Middle Ages [London, 1883], p. 237 ; Burckhardt, Arabic Proverbs, p. I16 sq.). Among the Turks the bridegroom, when unveiling the bride, gives her a present called jitz görimliik ("the seeing of the face "), generally consisting of a valuable ring (Löbel, op. cit. p. 35). At Constantine, in Algeria, "le mari ne doit point adresser la parole à sa femmenavant que l'union ait été consommée; pour faciliter leurs premières relations et éloigner la crainte de son cœur, il lui remet une certaine somme d'argent, qui sera calculée par exemple en donnant cinq francs par chaque 
Besides the fear of bas there 'may yet be another reason for the custom which requires the bride to come to her new home with dishevelled hair or without a belt; tangles or knots are looked upon as magical impediments and are therefore not infrequently avoided at childbirths and weddings. ${ }^{1}$ An idea of this kind seems to account for the fact that the bridegroom also, in some places, has no belt round his waist-a custom which I have found not only at Fez but at Tangier and elsewhere. ${ }^{2}$ But if a knot acts as an impediment, the undoing of it naturally has the opposite effect. The making of seven knots in the cord of the bride's drawers ${ }^{3}$ may be a sham attempt on the part of the

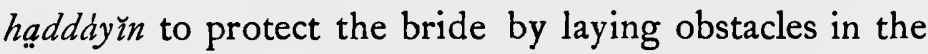
bridegroom's way, but I venture to believe that its real object is to give him an opportunity to facilitate the consummation of the marriage by untying the knots;

centaine de francs de la dot : c'est ce qu'on appelle le droit à la parole, haqq el keläm; il y ajoute parfois un bijou" (Gaudefroy-Demombynes, Les Cérémonies du mariage chez les indigènes de l'Algérie [Paris, 1901], p. 61). In Southern Algeria, "la jeune fille demande à son mari le droit de la première entrevue. Celui-ci donne immédiatement une pièce de dix, cinq ou deux francs, selon le plus ou moins d'aisance de la famille" (Villot, Mours, coutumes et institutions des indigènes de l'Algérie [Alger, 1888], p. 106).

I Frazer, Taboo (The Golden Bough, pt. ii.; London, 191 I), p. 294 sqq. (especially p. 299 sq.:- "Knots are supposed to prevent the consummation of marriage"); Samter, Geburt, Hoch «eit und Tod, p. 121 sqq.

${ }^{2}$ See infra, pp. 281, 293. Cf. Gaudefroy-Demombynes, op. cit.p. 74 (Tlemcen).

3 In Rome the girdle worn by the bride was tied up in a so-called "Herculean knot" (nodus Herculaneus)-particularly difficult to untie-" "quod vir in lecto solvebat" (Festus, De significatione verborum, ed. Mueller [Lipsiæ, 1839], p. 63). This custom was explained as being intended to secure a fruitful marriage, because Hercules had many children (ibid.). Modern writers have taken it to be an amulet against the evil eye (Marquardt, Das Privatleben der Römer, i. [Leipzig, 1886], p. 45 n. $^{2}$ ) or "the symbol of a stable marriage, and perhaps the original of the "true lover's knot" "(Smith, Wayte, and Marindin, A Dictionary of Greek and Roman Antiquities, ii. [London, 1891], p. 142). But perhaps the Herculean knot, also, was made for the purpose of being untied by the bridegroom. 
and this may have been thought the more necessary on account of the previous ceremony of tying the fringe of the bridegroom's hâỵ̧k while worn by the bride. ${ }^{1}$ These two ceremonies occur in the same tribe, Andjra, and I have heard of them nowhere else.

In many tribes, especially Berber, resistance is said to be made by the bride, and it seems that she is driven to it not only by instinctive bashfulness or fear but by custom or etiquette. ${ }^{2}$ Among the Berbers living near $\mathrm{Fez}$ and the Algerian frontier, as also the southern Jbâla, drastic methods are applied to subdue her, ${ }^{3}$ and in one tribe the best-man is actually present when the intercourse takes place.

The ceremonies which follow on the connection are, like those preceding it, largely of a purificatory or protective character; for evil forces are still active, and the hymeneal blood (called șdaq or şbah) in particular is a seat of danger. It is true that baraka and medicinal virtue is sometimes ascribed to it, but I have also heard the accuracy of this opinion emphatically denied; and, besides, baraka itself is more or less dangerous. I am told that in Andjra there are bridegrooms who take care that no offspring can result from the defloration of the bride, since many people believe that the child

1 Supra, p. 142 sq.

2 Among the Bedouins of Mount Sinai, the more the bride "struggles, bites, kicks, cries, and strikes, the more she is applauded ever after by her own companions" (Burckhardt, Notes on the Bedouins and Wahábys [London, 1830], p. 150). Cf. Biarnay, Étude sur le dialecte berbère de Ouargla (Paris, 1908), p. 473 sq.

3 Cf. Burckhardt, Bedouins and Wahábys, p. 15 I n.t:-Among the Bedouins of Sinai " it sometimes happens, as I have been assured, that the husband is obliged to tie his bride, and even to beat her, before she can be induced to comply with his desires." 
would be diseased if the semen came into contact with the hymeneal blood; whilst others maintain that the child will be all right if only the bride and bridegroom avoid cleaning themselves with the same towel.

In the early morning the bridegroom, after the necessary ablutions, prays and recites a surra of the Koran while still in his room, or goes to the mosque or the hot bath. In Andjra he walks out well covered up and with his eyes painted with antimony, which is a purifying substance, whilst in other tribes the bride paints herself with antimony and walnut root-the bridegroom having previously been painted with the same colouring matters-or has saffron smeared on her forehead and face. In some tribes the bridegroom after the connection pulls up the backs of his slippers as an advertisement that he has deprived the bride of her virginity, but also, I presume, as a precaution ; for he wears them in this fashion for several days, and in other cases, as we have seen, he has pulled up their backs already before meeting the bride.

In Sūs he fires off his gun if he has found his bride to be a virgin, ${ }^{1}$ whereas in other places a shot or generally two or more shots are fired by the best-man or other bachelors. ${ }^{2}$ This, also, serves as an announcement of the defloration of the bride or as a signal for

1 Among certain Algerian Kabyles "aussitôt que l'acte du mariage est consommé, le mari tire un coup de pistolet dans la chambre où il se trouve" (Féraud, loc. cit. vi. 431 ).

${ }_{2}$ Cf. de Calassanti-Motylinski, Le Djebel Nefousa (Paris, 1899), p. 113 ; Destaing, op. cit. p. 290 (Beni Snus). 
examining her clothes, but there can be little doubt that at the same time it is meant as a safeguard against evil influences, as is the case with the shooting on various other occasions; indeed, in one instance the two shots fired by the best-man are expressly said to destroy the bas of the bridegroom and of the bride. Similar ideas seem to be connected with the quivering noise made by the bride's haddady the bridegroom's mother, or some other woman or women of his family or village, or even by all the women who are present when the drawers of the bride are exhibited ${ }^{1}$ I take this noise to be not merely an announcement of the bride's virginity or a formal expression of joy but, as we have previously found it to be, a means of expelling evil. To the same class of ceremonies belong the singing and dancing round, or in the presence of, the blood-stained garment of the bride, and the woman's dancing with it on the top of her head. In one tribe the people who partake of the porridge served on this occasion smear a little of it on each other's faces, and porridge made of wheaten meal is naturally a purifying substance. ${ }^{2}$ In another tribe the drawers of the bride, together with a flag attached to a bamboo cane, are blown to pieces in order that the bas shall be destroyed. ${ }^{3}$ It is a common though not

1 Cf. Lane, Modern Egyptians, p. I 82 sq.

2 See Westermarck, Ceremonies and Beliefs connected with Agriculture, certain Dates of the Solar $Y_{e a r}$, and the Weather in Morocco (Offversigt af Finska Vetenskapssocietetens Förhandlingar, Bd. liv. Igrr-1912, Afd. B. No. I. Helsingfors, 1913), ch. i. passim; Idem, 'The Popular Ritual of the Great Feast in Morocco,' in Folk-Lore, xxii. (I9I I), p. $14^{2}$.

3 It is reported that in some places in Algeria the chemise of the bride is burned (Gaudefroy-Demombynes, in Revue des traditions populaires, xxii. [1907], p. 52). 
universal custom in Morocco that the garment with the marks of virginity is publicly exhibited. ${ }^{1}$

Sometimes, among the Shlöh, the bride or bridegroom, or both, join in the dance of the people in the night or morning, but only in case he has deprived her of her virginity and the pair consequently are in particular need of purification. ${ }^{2}$ To the ceremonial fights which follow on the consummation of the marriage I am likewise inclined to ascribe a purificatory significance. Sometimes there is a fight between the bachelors and women over the food brought by the bride's mother; this is said to have a beneficial effect, and as for the dung which the defeated party tries to throw into the dish it is worth mentioning

1 Cf. Villot, op. cit. p. 107 (Algeria). Burckhardt (Arabic Proverbs, p. 117 sq.) says that "among the lower classes of Moslims at Cairo it is customary that on the day after the nuptials certain female relations of the bride should carry her innermost garment in triumph to the houses of their neighbours. But this practice is not adopted by the more respectable inhabitants, among whom the chemise is exhibited only in the bridegroom's house to the women assembled there; and in many instances the people of high rank condemn even this exhibition as indecent, and no longer allow it." At Mecca the bride's mother shows the garment to the women who have spent the night in the house (Snouck Hurgronje, Mekka, ii. [Haag, 1888], p. I 85 sq.). The Aeneze do not require any indelicate proofs of virginity (Burckhardt, Bedouins and Wahábys, p. 62).

2 Among some Algerian Kabyles the bride dances in the midst of the guests, moving her blood-stained chemise with her hands (Féraud, loc. cit. p. 431). "Among the peasants of Upper Egypt, the relations and acquaintances of the bridegroom and bride meet together on the day after the marriage; and while a number of the men clap their hands, as an accompaniment to a tambourine or two, and any other instruments that can be procured, the bride dances before them for a short time. She has a head-veil reaching to her heels, and a printed cotton handkerchief completely covering her face, and wears externally the most remarkable of her bridal garments" (Lane, Modern Egyptians, p. 575). In Palestine the Rev. C. T. Wilson (Peasant Life in the Holy Land [London, 1906], p. 113 sq.) has seen a sort of effigy of the bride called Zarâfeh, consisting of some of her clothes stuffed with straw in the form of a person, fastened to a pole, and carried by a man who makes it appear to dance in the midst of the wedding guests; and it seems that the bride herself occasionally will come out and dance. On the custom of dancing at weddings in Europe see Sartori, op. cit. p. 103 sqq. 
that cowdung is in Morocco used as a means of purification. $^{1}$ Sometimes the islan and the unmarried women have a fight in the morning about the contents of the bride's mézwud; and sometimes the married men fight with the bachelors, trying to deprive the bridegroom of his slippers, turban, and other articles of his dress.

At Fez the women put money on the drawers of the bride when exhibited in the houses of the young couple's parents; but previously to this the men gave grama to the bridegroom, amid the quivering noise of women, while he was seated in the nuptial chamber immediately before his first meeting with the bride. In other places, again, the bridegroom is subject to a grâmaceremony on the morning after the marriage has been consummated.

Congratulations and good wishes are in the morning presented to the bridegroom, bride, and her mother. It is a common custom that a meal is then given by the mother, or that some food from her house is served to the bridegroom and bachelors or to the bridegroom's family or to other people as well.

After the consummation of the marriage, as well as before it, there are magical practices which are intended either to make the union fruitful or to improve the offspring. To a ceremony of the former kind the bride's or the bridegroom's mother is sometimes subject, whilst the order in which the bride and bridegroom

1 See Westermarck, Ceremonies and Beliefs connected with Agriculture, etc., in Morocco, pp. 80, 81,83 . 
wash themselves after the connection is supposed to influence the looks of the child.

If the bride is found not to be a virgin, she is frequently sent away and the price paid for her and the presents given for her have to be returned. Sometimes she is killed by her father, brother, or cousin, either on the spot or afterwards, or she is given in marriage to some man living in a distant place. But it may be that she is kept if one-half of the bride-price is given back, or that she is forgiven after a thrashing, or that little notice is taken of the whole affair. Among the Berbers near Fez and the Algerian frontier a bride is rarely or never sent away on account of lost virtue, and in order to save appearances the blood of a fowl is used as a substitute for the missing marks of virginity. ${ }^{1}$

Most commonly the bride and bridegroom meet and have intercourse the night after the former's arrival at her new home. In one of the Arab tribes, however, it is the custom for them to have connection on the previous night at the bride's place, whilst in some Berber tribes the bridegroom visits her only on the day after her arrival or later. Mr. Crawley has made the suggestion that the practice of thus postponing the consummation of the marriage, which is found in

I The following account was given by Mouette (The Travels of the Sieur Mouette, In the Kingdoms of $F_{e} z$ and Morocco, During his Eleven Years' Captivity in those Parts [trans.; London, 1710], p. 43):- "If he (that is, the bridegroom) finds her not a Maid, he takes off the Cloaths he has given her, and without seeing her Face, restores her to the Kindred, who conduct her back to the Father, and it is in his Power to Strangle her, if he will go to the Rigour. When the Matches are among Relations, those Ceremonies are seldom practis'd, for Fear of disgracing the Family; but for saving of the Formalities, the Husband kills a Pigeon upon a Pair of Drawers, which he throws out, and then unveils his Wives Face." 
various countries, is, like many other practices, due to the notion of sexual danger and illustrates the principle " that a temporary self-denial of a dangerous satisfaction will obviate the risks of its ordinary fulfilment " ${ }^{1}$ and he may be right. In Morocco the postponement of the act is closely connected with sexual shame; but we have previously noticed cases in which sexual bashfulness is combined with the feeling of superstitious fear, even though it cannot be looked upon simply as a later development of this feeling.

There are even cases recorded of the defloration of the bride being performed not by the bridegroom himself but by somebody else. An old man from the Hianina told me that the following custom formerly prevailed among the Beni Ulîd, an Arabic-speaking mountain tribe in the neighbourhood of Fez. On the evening of the day when the bride arrived at her new home the bridegroom, accompanied by members of his family and women, went to a neighbouring village to fetch from there a man to spend the first night with the bride and have intercourse with her. When they fetched him the women sang :

Fárḩi ya lälla u zỉd, u t-ťággab jāk men Bni Ulîd,

Rejoice $O$ lady and continue [to rejoice], and the perforator has come to you from the Beni Ulîd.

According to another account given me by two Berbers from the Ait Waráin and Ait Sáddenn, it was the custom among the Beni Ulîd that, if the bridegroom was not

3 Crawley, The Mystic Rose (London, 1902), p. 343. 
strong enough to deprive the bride of her virginity, he asked his best-man to inform his father about it and tell him to send for some man who was reputed for his virility. A messenger on horseback was despatched to fetch such a man, who was then received by the women singing the following ditty :

Fárḩi ya Ṭâma u zid, t-tqqab jāk men Bni Ulid,

Rejoice $O$ Tâma and continue [to rejoice], the perforator has come to you from the Beni Ulîd.

He was paid for his service.

Two men from the At Ubáhți told me that among their neighbours the At Zihri (Zkâra) it is the custom for the chief of the village to be secretly sent for by the bridegroom's family to have intercourse with the bride the first night, unless she be a widow or divorced wife. They said that this is well known to all the neighbouring tribes, though denied by the At Zihri themselves. This statement agrees with the information obtained by M. Mouliéras, although, according to him, the person who is said to perform the act belongs to the caste of the rusma, or spiritual leaders of the tribe. ${ }^{1}$

It is impossible for me to decide whether there is

I Mouliéras, Une Tribu Zénète anti-musulmane au Maroc (les Zkara) (Paris, 1905), p. 85 sqq. Of the ancient inhabitants of the Canary Islands it has been reported that "no maiden was taken in marriage till she had passed a night with the chief, which was held a great honour" (Alvise Cadamosto, 'Delle navigationi,' in Ramusio, Navigationi et viaggi, i. [Venetia, 1554], p. 106); or, that "the night before the bride was presented to her husband, she was delivered to the Guanarteme (or king), who, if he did not chuse to lie with her himself, gave her to the Faycag (a priest or lawyer next in dignity to the king), or to some other noble person of his intimate acquaintance, to enjoy her" (de Abreu de Galindo, The History of the Discovery and Conquest of the Canary Islands [London, 1764], p. 69). Abreu, however, says that "the present natives deny that such a custom ever existed among their ancestors"; this being written in $16_{32}$. 
any truth or not in these accounts from neighbouring tribes; but I think it may be worth our while to notice in this connection certain unusual customs peculiar to other Berbers, even though I do not wish to suggest that they actually are survivals of practices similar to those imputed to the At Zihri and Beni Ulîd. I have spoken of the curious behaviour of the best-man among the At Ubáhti, who is not only present when the bridegroom has intercourse with the bride, but jokingly claims his share of the pleasure, and of the remarkable intimacy between the bride and the imsnein or amsnäi among the Ait Yúsi, eating as they do under the cover of the same cloak and using the same spoon. Among the Ait Ndēr, again, the bridegroom appoints a bachelor or young married man from among his friends to be the bride's "vizier," and this implies that the young man shall spend with her the seven days following on the consummation of the marriage, retiring only at night when the bridegroom comes to her. He keeps in his hand a silk string, the other end of which is tied round the bride's headgear, and he does not leave her alone even when she must go out for a minute. When they have a meal the vizier throws a hâyẹ̆k (âban) over their heads, so that she cannot be seen eating by the people who come and go in the division of the tent where they are sitting. They eat out of the same dish, and if the bride is too bashful to help herself, the vizier pushes food into her mouth. When she wants to have a rest she sleeps with her head in his lap. In spite of all this I am emphatically assured that he never takes any undue liberties with her. 


\section{CHAPTER VIII}

THE CONTINUATION AND END OF THE WEDDING

AT Fez, in the afternoon of nhar s-sbah, "the day of the morning," which follows on nhar l-"ors, "the day of the wedding," dar islän gets filled with guests. The bridegroom and his company occupy a room by themselves; he is looked upon as a sultan, and one of his friends now appoints his ministers (wûzâra), notaries (kitts $\bar{a} b$ ), soldiers ('áskar), and so forth. In the centre of the house musicians (alîyen) are playing; tea is drunk, incense is burned, and about sunset a meal is served, after which the guests go home, except a few friends of the bridegroom, who remain overnight. But before the guests part the Sultan and his court pay a visit to dar l-'ors, where a feast is held the same afternoon.

The female relatives of the bridegroom are sitting there on mattresses in the centre of the house listening to the music of the tabbâlat ${ }^{s}$, to whom each of them throws some money enveloped in a kerchief. The women of the bride's family and other women have also assembled there, but only as spectators standing at the 
door with covered faces. The bride is lifted up by some ngâgef and placed on the top of a pile of mattresses (sder) opposite the door of the nuptial chamber; she is beautifully dressed and her face is uncovered, but she keeps her eyes closed. All the women come and look at her, and the bridegroom is sent for. He goes there with the dignity of a sultan, accompanied by his court. Both when he leaves dar islän and when he arrives at dar l-örs the soldiers line themselves up in two rows, and when he passes between them they bow and cry out :-Alláh ibârek fă 'mór sîdi, " May God bless the life of my lord." When he enters the house the tabbâlats strike up a tune. He proceeds into the nuptial chamber and sits down near the door for a few minutes looking at the bride, and then returns to dar islän after giving some money to the tabbâlats. At sunset supper is served in dar l-örs for the women; the tabbâlats then go away, and the htatatar, who spend the night in the house, retire to sleep. The bridegroom comes once more from dar islän to sup and sleep with the bride. It often happens that the young couple have their first intercourse this night, and in such a case the ceremony of the sarrwal, described in the previous chapter, takes place on the following day, which is called şbôhi.

In the afternoon of this day the ngâgef paint the bride's face as before, dress her up in a new costume,

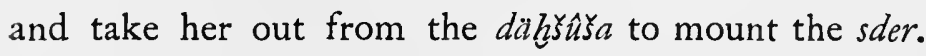
The htattar sit in the centre of the house, likewise dressed in clothes. different from those they wore previously ; for they, too, must every day wear a new suit 
of fine clothes, which is generally hired for the purpose. A new band of tabbâlats are playing, and the htattar give money to them also. In dar islän the bridegroom's friends are assembled, drinking tea and listening to the music of the aliyen. When the bride is sitting on the sder the bridegroom is again sent for; he comes to look at her with the same ceremonies as the previous afternoon, and returns shortly after. About sunset supper is served both in dar l-'örs and dar islän; but the bridegroom takes his supper in the däḩû́Ya with the bride. On this day he must give her a handsome present consisting of an article of dress.

The next day is called $t^{s} \hat{a} n i$ șbôhi. The ceremonies of the previous day are again repeated, but in the evening the male friends of the bridegroom go away for good, and dar islän is closed. The programme of the following day, which is called $t^{s} \hat{a} l t^{s} t^{s} s b \hat{h} h$, is the same as that of the day before, with the omission of the gathering at dar islän and the procession of the Sultan with his court. The bridegroom now spends his day in the upper part of dar l-ors or in the street, but he must come and look at the bride in the afternoon. The next day-the fifth after nhar l-örs-is called nhar hall $r$-ras, because the hair of the bride is then opened. In the afternoon when she comes down from the sder, she goes to the door and sits on a cushion. A nggâfa uncovers her head; the bridegroom undoes the end of one of her plaits, puts on her hair a silver coin, which is taken by the $n g g \hat{d} f a$ as her fee, and then leaves the room. The nggâfa now opens all the little plaits 
(dfayer, or diffrats) into which the bride's hair was made on the day before she left her old home-a head-dress called selt $t^{s} a$-and the coiffure of grown-up women, consisting of a plait on either side of the head, takes their place. The same afternoon the bride's mother sends her daughter three tables (miâdi), one loaded with small loaves of sweet spiced bread called qrâsel, another with hard-boiled eggs, and the third with $l \bar{u} z$ $m \dot{q} q l i$, that is, roasted almonds which have been put into salt water and afterwards dried. This gift is called l-hámmam, on account of the hot bath which the bride takes on the evening of the same day. The contents of the tables are eaten by the bride, bridegroom, and htâtar. Later on supper is served, and the bride goes to the hot bath in the company of some ngâgef, or she takes the bath in the house.

On the sixth day after nhar l-örs, which is called nhar $l a \underline{a}-\dot{g} s \hat{\imath} l$ because she was washed the previous evening, the ceremony of climbing the sder is preceded by a change of headgear: on her head is placed the so-called hantoz, a triangular pad covered with silk kerchiefs embroidered in gold-a head-dress which is used only by married women. When she is sitting on the sder this day, she keeps her eyes open for the first time. After she has exhibited herself for $a^{\text {" }}$

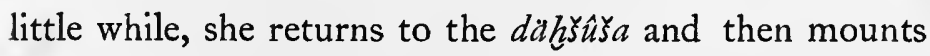
the sder another time, dressed in different clothes, and this is repeated till she has successively shown herself on the sder in seven different costumes. On this day it is usual for the bride's parents to send 
to the bridegroom's house some four or six miâdi, each loaded with a different kind of baking, besides one or two tables with sugar. There is the pastry called $k a^{\circ} b \dot{g} z e l$-crescents made of an icing of pounded almonds, sugar, and cinnamon, covered with an extremely thin coat of paste. There are the grîbabuns made of flour, sugar, and butter. There is the mhansa-icing of pounded almonds, cinnamon, sugar, and butter, rolled out into a long strip which is enveloped in paste and twisted into a spiral. There is the pastry called brệwats_-small triangles made of pounded almonds, cinnamon, and sugar, enveloped in a paste and then boiled in oil and, when still hot, poured into a vessel full of honey. There is, finally, the bstêla-a pie consisting of stewed pigeons placed between two round pieces of dough, which are closed up and baked. Each table, covered up with a mkeb and embroidered cloth, is taken to the bridegroom's house on a nggâffa's head. This gift is called lë-ftôr, " the breakfast."

The food on the tables is left to be eaten at a banquet, which some days afterwards is given in the bridegroom's house, and to which are invited the men of the bride's family as well as those of his own. About noon they assemble and drink tea with $k a^{i} b$ gzel and grîba, while aliyen are playing and singing. Then a meal is served consisting of mutton boiled in oil and butter with the addition of saffron and peppercorns, fowls likewise boiled in butter and oil, mhánY̧a, bstêla, and brệwatts. Both the bridegroom 
and his father take part in the banquet; it is the first occasion on which the latter is present since the commencement of his son's wedding. The day on which this feast is held is called nhar le-ftôr, but it takes place only if lë-ftiôr has been sent by the bride's parents; in the opposite case there is no gathering in the bridegroom's house in which the bride's family join before the next religious feast. When the tables are sent back they must not all be empty: on one of them is placed a fine new garment bought by the bridegroom's father or the bridegroom himself as a present for the bride, to whom it is afterwards handed over by her parents.

On the day following nhär lặ-ģsill the ngâgef and htâtar leave dar l-örs, and the wedding has now come to an end. Two or three days afterwards some ngâgef come and take away the mattresses and all other things that do not belong to the house ; the day when this is done is called nhar tîh l-fařs.

In Andjra the day following the fetching of the bride is called s-șbah del-'ărûsa $u$ del-ărôs or also

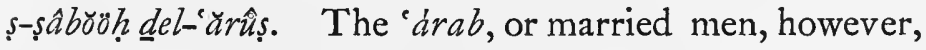
call it nhar t-tsetruif, "the day of ambulation." They are again very troublesome. After the meal spoken of above they seize hold of the male relatives of the bride, tie their hands behind their backs, and push them against or through the door of the room where the bride is staying. The 'arab complain of hunger; the hadday in give them bread and rgaif, 
and set free the bound men. The 'drab now catch and bind men from among the bridegroom's relatives and push them into the room of his parents, who in their turn have to give them food to release the prisoners. The 'árab then tie up the bridegroom's brother and take him about in the village from house to house amid a continuous banging of guns, beating him at every house so that he cries, and receiving bread and rigaif from the people, who at last succeed in liberating him. After this the 'árab go to the room where the bride is sitting, discharge volleys of gunpowder at the door, and insist in a most insolent manner on having food, which is also given to them by the haddayın; and the same is repeated outside the room of the bridegroom's parents.

In the afternoon the women of the village again visit the bride, and a woman from each house gives her a small sum of money. They are all served with küsksu and meat and entertained with singing and music by the fqira and her assistants, who in return receive a small gratuity from the women. The bridegroom's mother sends a large quantity of food to the mosque to be eaten by the unmarried scribes who are sitting there with the bridegroom, by the $f q \tau$ and schoolboys, and by the poor, who have their meal outside the mosque. After the sunset prayer the bridegroom leaves the place together with those of the wazara who are scribes, goes to his parents, kisses their hands, and receives their blessing, Allah yerd 'ălik. Then he goes to the bride, and the wazâra throw into the room the 
flags, cushions, carpet, and handkerchiefs which were used for waving, and shut the door. The huntsmen among them fire off their guns outside the room, after which all the wazâra retire to the mosque carrying with them four or five dishes of küsksu presented by the bridegroom's mother.

On the following day, which is called n-nhar l-ménsi, "the forgotten day," the bridegroom remains in his room with the bride without going out at all, not even for necessities, his mother bringing the young couple food and also attending on them in every other respect. On this day she presents her daughter-in-law with a dollar. The following three days the bridegroom likewise remains with the bride; if he went out then he would run the risk of being caught by the 'arab, who would not set him free until he entertained them with a good meal. On n-nhar l-ménsi the bridegroom does not put on his girdle lest the offspring should be sickly; but this is the only day when he is subject to such a taboo.

Both in Andjra and among the Tsül the guests go away the day after the arrival of the bride, but in the latter tribe the young men remain with the "Sultan" for seven days. This assembly is called yislän. One day they go to the market with music and a white flag, the bridegroom riding and the others on foot. The people there give them henna, figs, raisins, oranges, and other things, but no bread; and the butchers give them money instead of meat. 
In the Hiaina, on the day following the weddingnight, the "Sultan" and islan make a walking tour from village to village, the Sultan with his sword hanging over his shoulder and the hood of his cloak drawn over his face. When they arrive at a house the "vizier" throws into it the white flag which they are carrying with them, saying:- $H a$ "äwaid l-árab, "Behold the customs of the Arabs." This is a kind of " $a r$, which compels the owner of the house to give them both a meal and a sheep or goat or some money. So also when they meet people on the road they throw on them the flag, repeating the same phrase. A similar tour is made every day for seven days in succession, but in the evenings, about sunset, the party return to the bridegroom's village, where they have their supper together, the bridegroom then retiring to sleep with the bride. The sheep and goats are slaughtered and eaten in the village, while the money is kept by the bridegroom till the seven days have come to an end, when he divides it into two equal shares, keeping one share for himself and distributing the rest among the islan.

Among the Ulåd Bu-Ăzîz the bridegroom and his

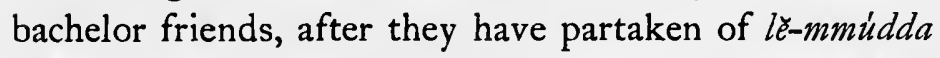
dyālt l-mra and fâtha has been made, "make y̆̌slän" (idîru y̌̌slän). The bachelors paint the bridegroom's and their own eyes with antimony and the lips with walnut root. The bride gives them her belt and a skin-bag (d́ábya) containing dates and a few silver coins, which she and her female friends present to 
them for good luck. These things the young men take with them on the tour which they now make mounted on horses, mules, or donkeys, visiting the tents in their own and neighbouring villages, the bridegroom, or "Sultan," with his face covered as before. They first go to the tent of his family, who ask them, "Give us camels." The yislän offer them dates and get money in return. This is repeated at the other tents where they call. When the dates come to an end they answer, "The camels are away to Marrakesh"; but money is all the same given to them by the people. While the bridegroom and his friends are away the women both of his and of the bride's village make t-tăzyina on their faces. They paint the bride's and their own eyes with antimony, the cheeks with ochre, and the teeth with walnut root, apply hargos (hárqos) ${ }^{1}$ to the eyebrows and the bridge of the nose, and paint with the same colouring matter a line along the nose, another round the cheeks and over the chin, and a third from the under-lip downwards. The women of the bride's village then go home with the exception of her mother.

When the bridegroom and his friends return from their tour and approach his tent, he and two or three others dismount and run fast to the division of it where the bride is sitting. There the bridegroom remains, whilst the bachelors go to amuse themselves with singing and playing, accompanied by the musicians, who have been with them all the time. The tour is 
repeated for the following six days, but the bridegroom does not take part in it every day; when he stays at home he is represented by one of his friends who imitates his dress. The party also visit the marketplace, where they are presented with eatables and money, and in return call down blessings on the donors. With the money collected on these tours they buy a sheep, some sugar, and tea, as also cotton and silk goods for the bride; and when they return from the market they have a feast in the bridegroom's tent.

Among some of the Berbers the wedding ceremonies likewise include tours made by the bridegroom and his friends. Among the Ait Nderr the bridegroom, or "Sultan," and islan start for their first tour in the morning of the second day after the consummation of the marriage, and, if the wedding is a big one, repeat it during the following four or five days, though not necessarily every day. They walk about from village to village. When a meal is wanted in a tent which they are going to visit, the Sultan sends there in advance two of the islan, one carrying a gun and the other one a cane with a red ${ }^{1}$ silk kerchief belonging to the bride as a flag. The latter beats the tent with the cane, and this compels the inhabitants to prepare a meal, which has to be ready when the others arrive. The entertainment, however, must afterwards be returned in a similar manner, when there is a wedding in the tent of the 
host; hence custom requires that it should only be asked of a family with an unmarried son. But the older married men, ${ }^{1}$ representing rebellious Arabs (ärabenn), follow the islan and claim the meals for themselves. This leads to wrestling matches between the parties, in which, however, neither the Sultan nor his "vizier" take part; but whoever come off victorious, the defeated ones are also allowed to join in the meal. A little of the meat, eggs, and other food served on these occasions, but neither séksu nor bread, is every day preserved by the vizier and in the evening given to the bride; and in one of the villages a hen is caught by the islan, likewise to be given to her by the bridegroom, who pretends that it is a she-camel he now presents her with. This hen, which is a compulsory present, is not killed, nor are the eggs it lays eaten, and the chickens which come from them are the wife's property. In the villages which they visit the islan also receive money and presents of corn, fowls, eggs, and other articles, which are afterwards sold ; of the money the bridegroom keeps one-half for himself and distributes the other half among his companions. Every evening they come back to their village, and the bridegroom spends the night with the bride. In the daytime, while he is away, the bride is guarded by her vizier, as has been said above. She kisses the head of every grownup person who enters the place where she is sitting, and receives some money in return.

Among the At Ubáhți similar tours, likewise on foot,

1 Among the Ait Nderr the islan $n$ also comprise the younger married men. 
are made by the bridegroom and his bachelor friends. Here also they start on the second day after the bride's arrival, and return every night; but it may be that when the wedding week has come to an end they make another tour to more remote villages, staying away for seven days. They have constant fights with the socalled legwał̧̧̧, or married men-both those from the bridegroom's village and those in the villages they visit -but are themselves supported by all the bachelors. The legwdyey try to rob the "Sultan" of his slippers and the bride's belt, which he wears round his head, and the "vizier" of his flag; and the islān have then to buy back the captured things. Among the At Ubáhti, also, the money collected on these tours is divided between the bridegroom and the bachelors, who buy powder with their share of it.

We have seen that among the Ait Wäryâgäl and Ait Warain similar tours are made before the wedding. Among the former it is the custom that on the morning after the consummation of the marriage the bridegroom a second time enters his room, after the women who came to examine the bride's clothes have left; and he now stays there till the wedding week has passed. When he comes out again, he no longer has his head covered with the hood of his cloak. On the next market-day he goes out and buys either a head-kerchief

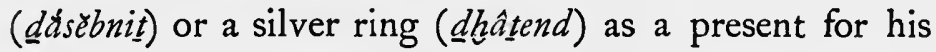
wife.

Among the Ait Warain, on the other hand, the bridegroom and his bachelor friends, who sit together 
the first day after the wedding-night, go out to hunt on the second morning, and stay away for the rest of the day; and the same thing is repeated the two following mornings. If the bridegroom's family are not particularly well-off, the wedding festivities now come to an end, but otherwise they may last for another couple of days, which are spent in eating, singing, and playing.

Among the Ait Sadden the wedding festivities come to a close with the following ceremony. A sister, paternal cousin, or other female friend of the bridegroom, either married or unmarried, takes to him a palmetto tray (iswi) with dried fruit-figs, raisins, and datesand some silver money varying from a quarter to two dollars. Carrying the tray on her head she goes to him accompanied by a crowd of women and men, who are singing, playing, dancing, and discharging volleys of gunpowder. $\mathrm{He}$ is sitting in the house of a relative or friend, with the hood of his cloak drawn over his head, and when they arrive there the woman hands the tray to the imsnein, who put it down in front of him, remove the silk kerchief covering it, and pour out the contents. The bridegroom takes some money from his bag, ties it up in the kerchief, and puts it on the empty tray as a present to the woman, at the same time giving her his blessing just as the Sultan blesses his subjects. The sum which he presents to her may even amount to some ten dollars, if she is an old friend of his. In very many cases the same ceremony is then repeated by other 
sisters, female cousins, or friends of the bridegroom, their number largely depending on his ability or willingness to give a handsome present in return for theirs; whereas if he is a poor man who has no sister it may happen that nothing at all is offered him. The woman's present of dried fruit is called tiswit, diminutive of iswi, and is considered to bring good luck; it is distributed by the bridegroom among the bachelors. In this ceremony, which is performed either on the first or second day after the fetching of the bride, only people from the bridegroom's village take part, the guests from other villages having already gone away. For some time the bridegroom still spends his days in the house of a friend, being shy of his parents, and visits the bride only at night, until, on the sixth day after her arrival, he is taken to his parents to kiss their heads; and on the following day he for the first time after the wedding appears in public with uncovered face.

Among the Ait Yúsi the day after the pair have had connection is spent by the bride in the company of the imsnein in the tent, where the wedding is still continued. In the evening she is again taken away by the imsnein to meet the bridegroom, and on their return they eat together a dish of $\dot{u}^{\prime} y u$, as on the night before. The following day the guests and imsnein leave the place, and henceforth the pair spend the nights together in a section of the tent behind a curtain, though secrecy is still preserved for some time. In other cases, again, the bridegroom, who had his first intercourse with the bride in a place outside the village, comes the next night 
stealthily to his tent and disappears at daybreak; and this is repeated the three following nights or longer.

Among the Igliwa the bridegroom for a few days neither walks about in the village nor does any work, but spends his time sitting with his friends. The duration of the wedding festivities depends on the means of the bridegroom and his family, lasting sometimes a night only and sometimes three or four days. Among the Ait Táměldu the guests are entertained by the bridegroom's family for three days after the evening of the bride's arrival; on the fourth day they are served with food from other households in the village, and the next morning they go away. Meanwhile the bridegroom is sitting in a special room together with his bachelor friends, without showing himself to the people. Even on the occasion when he threw dried fruit and bread on the blanket held over the bride and on the crowd around, he was not seen by them.

It is not merely out of bashfulness but, no doubt, also for fear of evil influences that the bridegroom thus lives in retirement for some time or covers up his face. ${ }^{1}$ $\mathrm{He}$, as well as the bride, is still considered to be in a

I Among the Berbers of Ouargla, in Algeria, "pendant les sept jours qui vont suivre la consommation du mariage, les nouveaux mariés ne peuvent, sous aucun prétexte, sortir de la maison nuptiale" (Biarnay, Étude sur le dialecte berbère de Ouargla [Paris, I908], p. 474). Among the Touareg of the Ahaggar, during the same period, "les nouveaux époux ne quittent pas leur tente : on vient les y distraire et leur rendre visite" (Benhazera, Six mois chez les Touareg du Ahaggar [Alger, 1908], p. 18). Among the Bedawin of Palestine bride and bridegroom "remain in seclusion for eight days, or retire to the hills and live alone for a month" (Robinson Lees, The Witness of the Wilderness [London, 1909], p. 123). Cf. Genests, xxix, 27 :- "Fulfil the week of this one." 
more or less delicate condition and exposed to supernatural dangers. In the Hiáina he wears throughout the wedding week the charms which he assumed at his rbet. ${ }^{1}$ Among the Ait Warain, Ait Nderr, and At Ubáhți he carries his sword or pistol for the same period, every night hanging it up on the wall at the head of the bride or putting it on the bed or underneath the pillow. In various Arab and Berber tribes (Ulâd Bu-Ǎzîz, At Ubáhți, etc.) he keeps the backs of his slippers pulled up till the end of the same week, in some tribes (Aiț Sádděn, Aiț Yúsi, Ait Nderr) even leaving the slippers on his feet at night; and the same is the case with the bride. There is fear lest some malevolent person should get hold of them and thereby be able to work magic on their owner. An old man from the Ait Yúsi told me that once when he, as a bridegroom, removed his slippers (ibürhsěn), some enemy took them away, with the result that he no longer loved his bride; she now appeared to him like a black cow, and he divorced her soon afterwards. In the same tribe bride and bridegroom protect themselves against magic by putting a needle in their right slipper; and it is the custom that the slippers worn by them should never be repaired. Among the Ait Nder and At Ubahhti they must abstain from bathing throughout the week of the wedding, and the bridegroom is not allowed to have his head shaved. Among the Ait Warain he has his head shaved only when he goes to visit his parents-in-law a fortnight after the girdling 
of his wife. Among the At Ubáhti and Ait Waráin he must not change his clothes. In Andjra the bride has her hair open during the wedding, and among the Ulâd Bu-'Azîz the same is the case with the bridegroom's mother and the other women of his family as well. ${ }^{1}$

The bride commonly remains in her seclusion till the sixth or seventh day after her arrival. ${ }^{2}$ On this day there are certain ceremonies which indicate the end of the wedding and the beginning of ordinary married life.

In Andjra the bridegroom on the sixth day saddles his mule and, accompanied by a married sister or some other married woman from among his relatives, goes to visit his parents-in-law; he takes with him some rgaif, ordinary bread, cooked chickens, eggs, and dried fruit, to give to them-a present called t-tajjin del-'arrûs, " the earthenware dish of the bridegroom." He kisses them on the head, and spends the night in their house. Next day he returns in the company of his mother-inlaw, who takes with her on his mule the same kinds of food as he gave her and her husband; and the unmarried women and little girls of the village go with

1 The following taboo is mentioned by the Rev. C. T. Wilson in his book on Peasant Life in the Holy Land (London, 1906), p. 114 :- "In some parts of the country neither bride nor bridegroom may cross a stream for a period of seven days after the wedding, as this would be most unlucky, and would mean the cutting off the succession, the Arabic idiom for crossing a stream being that of cutting it."

2 Cf. supra, p. 289 n. ; Jaussen, Coutumes des Arabes au pays de Moab (Paris, 1908), p. 54 :- "Dans les campements, un endroit spécial dans la tente appelé bullah est disposé pour la fiancée ...; c'est là qu'elle passera huit jours en comptant comme premier le soir de l'entrée." The Bedouins of Sinai think it decent that a virgin bride should remain at least one fortnight in the interior of her tent, leaving it only at night (Burckhardt, Notes on the Bedouins and Wahábys [London, 1830], p. 152). 
them, so that they also shall marry. On their arrival they are received by the bridegroom's parents, who kiss the bride's mother on the head. She enters the room alone where her daughter is sitting, and the latter, who now sees her mother for the first time after the beginning of the wedding, repeatedly kisses her head and hand and asks the mother to bless her. Subsequently the room is filled with the girls who came from the bride's village and the girls and little boys of the bridegroom's village, whose hands she kisses and who in return kiss her hand. But before the others enter, the bridegroom's mother takes into the room a palmetto tray with rgaif, ordinary bread, and dried fruit, out of the food brought from the bride's old home, as also eight candles provided by herself. She puts a loaf of bread on her daughter-in-law's head, and ties another loaf on her back, in order to give her baraka. Standing on the tray with the rest of the food at her feet and with her hands over her head, the bride has now her belt put round her waist by an uncircumcised boy, while the other little boys encircle her with the lighted candles in their hands. She then crosses her arms over her chest and in this position eats some bread and rgaif put into her hands by the boy who belted her. The loaves of bread which she had on her head and back are deposited in her trunk, as there is baraka in them. Food is given to all the people in the room, particularly the little boys, while the men of the village are entertained with a meal in the mosque, partly out of the provisions brought by the bride's mother. This day is called 
n-nhar s-sába del-earûs u del-"ărûșa, "the seventh day of the bridegroom and bride," or nhar l-hạzạm, "the day of the girdle." The girdling of the bride takes place in the afternoon.

At Tangier the bride is belted in the evening of the seventh day after her arrival by two little boys, to each of whom is given a raw egg and some dried fruit; I was told that the object of this ceremony is to make her a mother of sons and her life white. ${ }^{1}$ On the same day the bridegroom also resumes his girdle, ${ }^{2}$ which he has not worn since he had his hot bath previous to the arrival of the bride; and he celebrates this occasion with a garden party for his friends. Among the Tsul and Ait Warain the bride is girdled on the morning of the seventh day, among the former by a little boy-for the same reason as in Andjra and Tangier-and among the latter by the bridegroom. In other tribes (Hiaina, Ait Sádděn, Ait Yúsi, Ait Ndēr, Aț Ubáhți) the girdling of the bride takes place on the sixth day after her arrival. In the Hiaina, where this ceremony is called lă-hzậm dyäl lü-rûsạ, it is performed by some

1 The Shareefa of Wazan (My Life Story [London, I9I I], p. 137 sq.) gives the following description of the belting of the bride at Tangier :- "She stands on the bed over a dish containing dried fruits and sweetmeats, and two little boys wind the belt round her waist with the aid of a professional dresser, who in turn hands the dish and contents to the children. At the same time the bridegroom's mother gives a piece of silver to each boy. The toilette and belting being completed, the bride is assisted from the bed; now she may open her eyes, and, with lighted candles, music, 'zahrits,' incense and scent sprinklers before and behind, the tour of inspection is commenced. The bride stops at the doorway of each room, and on arriving at the kitchen door a fish is produced, and a pretence is made of scraping it on her foot-a symbol of plenty in the culinary department." For the use of fish in connection with weddings, see infra, p. 299.

2 Cf. Gaudefroy-Demombynes, Les Cérémonies du mariage chez les indigènes de l'Algérie (Paris, 1901), p. 74. 
respectable elderly woman, by preference a shereefa, but in no case by the bride's mother or mother-in-law. Among the Ait Sádden, who call the day in question ass ühazzam, "the day of the girdle," or ssibä n-tslit, "the seventh [day] of the bride," she is belted by her girl-friends, among the At Ubahţi by the woman who has been attending her, and among the Ait Yúsi and Ait Nder by herself. ${ }^{1}$

The girdling of the bride is evidently looked upon as a somewhat dangerous undertaking. Among the Ait Waráin the bridegroom gives her a small sum of money as soon as he has tied the belt round her waist, just as he gave her money after plaiting her hair. In the Hiaina the ceremony is performed in the presence of women who are playing on tambourines (bnâder and $t^{5}$ arj) and making a quivering noise, and the same day there is a sacrifice, called $d b e h t^{s} l \not a-h z a ̂ t m$, which reminds us of the little sacrifice made to destroy the bas emanating from the loosened belt of a strange woman who spends a night in another person's house. I was told that among the Arabs of the Ulâd Jâma in the neighbourhood of Fez the girdling of the bride is likewise followed by the slaughter of a sheep or goat : she herself keeps hold of the animal when the bridegroom cuts its throat, and he then wipes the bloody knife on

\footnotetext{
I Among the Beni Snūs in Algeria the young woman resumes her belt when the seven days of marriage have passed (Destaing, Ėtude sur le dialecte berbère des BeniSnous [Paris, 1907], p. 290). At Mazouna, a small town in the same country, the bride is on the seventh day solemnly girdled by the women of her family; "on fait, ce jour-là, de petits gâteaux de semoule, therid, qui sont vendus un sou à chacune des femmes présentes" (Gaudefroy-Demombynes, in Revue des traditions populaires, xxii. [1907], p. 53).
} 
her clothes. The burning candles and loaves of bread in the Andjra ceremony look like safeguards against evil influences, and so does the distribution of bread or dried fruit there and at Tangier, charity being a method of purification. ${ }^{1}$ Among the At Ubáhti the woman attending the bride not only puts the girdle round her but also on the same occasion paints her with henna, ochre, antimony, and walnut root. Among the Ait Yúsi the bride, after girdling herself, smears her hair with henna and covers it with seven kerchiefs. Among the Ait Sádden the bride's girl-friends, after they have belted her, give her antimony and walnut root to smear on her eyes and lips, one of them paints the design called izriran with saffron on her face, and they apply the same cosmetics to themselves and each other. Yet though these ceremonies of painting seem to have a purificatory origin, they may serve a wider purpose of purification than merely neutralising the dangers resulting from the girdling of the bride. This is undoubtedly the case with certain other ceremonies still to be mentioned.

In Andjra, on the evening of n-nhar s-saba the bride takes one of the loaves which she put into the trunk and goes to the spring which supplies the household with water; she goes there alone and in secret, without speaking to anybody or looking back. She drops some pieces of the loaf on her way, puts some

I See Westermarck, 'The Popular Ritual of the Great Feast in Morocco,' in Folk-Lore, xxii. (191r), p. 135 sqq. See infra, p. 370. 
round the spring, and throws others into the water, saying, Ana mẹd dyâf llah u mèd dyâfkum, a mwâlin l-blad, "I am [one] of the guests of God and of your guests, O owners of the land." Being a stranger, she thus places herself under the protection of the spirits and saints of the district. She also gives seven pieces of bread to the dog of the house, putting them one after the other on the top of her foot and letting the dog take them from there so as to make it friendly. From the spring she brings back a bottle of water to wash herself with, after putting salt into it as a protection against $j n \bar{u} n$. Next morning before sunrise she goes secretly, accompanied only by a young brother of her husband, to the patron saint of the village or the sîyid nearest the house, taking with her a cock, onehalf of the other loaf in her trunk, a dẹrhạm, two candles, some gum-benjamin, a little charcoal for burning it, and matches. She addresses the saint with the words, Ana mëd dyāf llah u mĕd dyâfạk, a sîdi l-wâli, "I am [one] of the guests of God and of your guests, O my lord the saint;" as a stranger she does not yet know, or is not supposed to know, the name of the saint. The cock is killed by the boy, and the knife with which it is done, and also the bread and dérham, are left at the siyid. The other half of the loaf is kept for ever after in the trunk, so that there shall always be bread in the house.

In the Hiáina the bride, as soon as she has been girdled, goes, with her face still covered up, to a river, spring, or well, in the midst of the women, who go on 
with their music and quivering noise. Her mother-inlaw takes with her some bưsiyạr, which she breaks into pieces and gives to the bride and other women to eata ceremony called le-fts $\hat{a} t^{s}$, meaning "the crumbs." The bride fills a large earthenware bottle (bî́s) with water and carries it home on her back. With some of it the uzîra washes her right foot; and now she no longer keeps her face covered. It was said that the water washes away her "sins" $(d n \bar{u} b)$.

Among the Ait Yúsi the bride, after belting herself, goes with the skin water-bottle (aiddid) of the household to the place from which they generally get their water, and other women, married or unmarried, accompany her, likewise carrying with them their waterbottles. She fills her own bottle with water and then six others, in the hopes that by doing so she will give birth to seven sons. A similar custom prevails among the Ait Sáddenn, where the procession consists of all the women and children of the village, who are singing and clapping their hands.

In Aglu, when the week of the wedding is finished, the bride goes to a spring with other women and a boy whose parents are still alive. He gives her twice water to drink from his hands and, after filling them a third time, washes her face with the water. She then fills her bottle from the spring and carries it back on her shoulder. The procession is headed by the luzîra, who holds in her hand a pail (tálmärjëlt) containing tummit, a mixture of roasted corn and salt, and of this she gives a little to anybody they meet on the road. 
It seems obvious that these water ceremonies, at least in part, are meant to rid the bride of the bas still clinging to her; and when they follow immediately on the girdling they are also perhaps intended as safeguards against the particular dangers resulting from this act. I was told that among the Ulâd Jâma bride and bridegroom, after the sacrifice spoken of above, have a bath in a river or spring with their clothes on and throw water over each other. The idea of purification may also underlie the distribution of bussiyạr and tummit, like that of bread and dried fruit at the ceremony of belting. The purifying character of water makes the fetching of it the most suitable beginning of the young wife's household duties. Among the Ait Yúsi she also grinds some wheat and prepares the supper, which consists of aftal (séksu) with salt butter and milk. Among the Ait Sádden the young wife goes alone to fetch some palmetto leaves, of which she makes a small rope ; this is the first handwork she does in her married state, and its object is to bring to the house many horses, mules, and cattle, each of which is, as usual, to be tied up with a small rope at night. Among the Tsal the young wife likewise goes and gathers some fresh palmetto leaves after she has been girdled, and this was said to make her days "nice and green" and the year blessed. In the evening she prepares the supper herself.

Among the Ait Warain the girdling of the bride is followed by the following curious ceremony, to which she and her mother-in-law are subject. The bachelors 
tie them each to a tarkizt-one of the vertical poles supporting the roof-by twisting a rope round the woman's waist and the pole and pulling it at both ends in opposite directions so that it tightens. It is believed that she who first cries out will be ruled over by the other.

Among the Ulåd Bu-Ăzîz the bride spends the week of the wedding behind the curtain in the tent, and only leaves her prison on the evening when that period comes to an end ; but she is still bashful and covers her face, except the eyes. On this occasion her mother, outside the tent, entertains the women of the place, including her daughter, with a supper consisting of buisiyär and dates, and next morning she goes back to her home.

At Fez on the ninth day after nhar l-örs the young wife must make bread, which, as usual, is sent to a public oven to be baked, and her husband buys some fish which he gives her to prepare. The bread is made in order that there shall always be much bread in the house, and the fish is supposed to bring prosperity; to eat fish is generally considered to be lucky. In his description of the marriage customs of $\mathrm{Fez}$ some four centuries ago Leo Africanus writes :-

"So soone as the new married man goeth foorth of the house (which is for the most part on the seuenth day after the mariage) he buieth great plentie of fishes, which he causeth his mother or some other woman to cast vpon his wiues feete; and this they, from an ancient superstitious custome, take for a good boading." 1

\footnotetext{
1 Leo Africanus, The History and Description of Africa, ii. (London, 1896), p. 45 I.
} 


\section{CHAPTER IX}

\section{LATER CEREMONIES AND TABOOS}

WHEN the wedding and the ceremonies mentioned at the end of the previous chapter are over, the young wife may still for some time be subject to certain restrictions. At Fez she must remain inside the house for two months, or at least six weeks, not even being allowed to go on the roof. At Tangier she was formerly obliged to stay at home for a whole year, but this period has been reduced to three or four months. In Andjra and among the Ait Wäryâgall there seems to be a rule that she should keep to the house and its immediate neighbourhood for forty days, but in the former tribe at least the time, as a matter of fact, varies considerably according to the circumstances.

As soon as the young wife is allowed to leave her new home she pays a visit to her parents, in certain tribes on the very day she has been girdled. In some places it is the custom for her to be accompanied by her husband, in others not; but if he does not go with her he may afterwards make a formal call alone on his parents-in-law. 
At Fez the young husband does not accompany his wife when she goes to visit her parents, but two or three days afterwards he sends them the so-called noffqa, consisting of a lot of chickens, sugar, and tea. After another couple of days she goes to the hot bath, and a $n g g \hat{a} f a$ then dresses her up as a bride, though not in any of the clothes she wore at the wedding. When she has spent a few days with her parents she returns home after sunset in the company of the $n g g \hat{a} f a$, who holds a wax candle in her hand, and four black women, who carry the same number of miâdi, loaded with chickens, meat, $k a^{\prime} b \dot{g} z e l$, and $\dot{g} r i \hat{b} a$ respectively. This present of food from her parents is called $l a a^{\prime} \zeta a$, "the supper." The following day, in the early afternoon, her husband gives a little feast, to which he invites his father-and brothers-in-law, as also some friends. The young wife is again dressed up in a new costume by the $n g g \hat{a} f a$ and then, for the first time, ascends to the roof of the house, where she remains till sunset; and the same ceremony is repeated the two following days.

At Tangier the occasion when the young wife for the first time leaves the house and goes to see her parents is called l-hárja, "the going out." She takes with her some food as a present for her mother, who gives a feast with her friends as invited guests. Next day a feast is given for the girl-friends of the young wife. She remains with her parents for about four days or a week, and, before she leaves, presents her mother with materials for a dress. Afterwards her husband makes a call on her parents. 
In Andjra the young wife visits her parents in the company of her husband and sister-in-law, and takes with her some bread, dried fruit, and other food. This is called z-ziâra del-arûsa, " the reverent visit of the bride." Her mother gives of the bread, which is saturated with the baraka of the bride, to the people of the village, who bring food as hospitality to her daughter. This visit lasts for about a week.

Among the Tsal, about a month after the girdling of the bride, she and her husband go to kiss the heads of her parents and other members of her family. $\mathrm{He}$ takes with him some flour and meat or, if his parentsin-law live near, a dish of küsksu and meat. Next morning after breakfast he again goes away, whereas his wife remains with her parents for five or six days, if they live at some distance from her new home.

Among the Ulâd Bu-Ăzîz two or three months elapse before the young wife goes to see her parents, accompanied by her mother- and brother-in-law, but not her husband. She gives to her father a sheep as well as some flour and dates, and he in return presents her with a cow. This visit, which lasts for five or six days, is called dhol l-haima, "the entering into the tent."

In the Hiaina, on the other hand, the young wife pays her visit on the evening of the day after she has been girdled. Her mother- or sister-in-law accompanies her, and they take with them some flour and sugar and the meat of a sheep slaughtered for this occasion. On their arrival her mother washes her daughter's feet 
with milk, which was said to be a good thing to do. The daughter kisses her parents on the forehead and removes their slippers, which she kisses seven times; and if there are brothers or sisters she kisses their hands. Other relatives soon assemble in the house and are received by the young wife with a kiss on the head. Supper is served, henna is pounded, and the wife and other women, with the exception of her mother, smear it on both sides of their hands. In the morning she goes out and sprinkles henna on the cattle, sheep, goats, and horses, which is supposed to be good for them, as there is still baraka in the young wife. This visit has from its chief feature, the kissing of the head, got the name $h a b b b r$-rùs. The wife spends one night only in her parents' house, and then goes with her companion to visit other relatives in the village ; and all those who received réswa when she was given in marriage now present to her money or articles of dress. These visits may take a week or more. Before she leaves the place her father gives her a bullock or cow, meat, flour, buisiygar, sugar, figs, and so forth. On her way back she is also accompanied by her own mother and her fatherin-law, who have come after the others to pay the remaining portion of the șdaq so that the young wife shall not be detained but be allowed to return to her husband. Her homeward journey, too, is made in the evening, as she is still considered to be very susceptible to the evil eye. Her mother is, on her arrival at her daughter's new home, painted with henna, and the young husband comes and kisses her on the forehead and 
cheeks and gives her some money; this, however, he only does reluctantly, as he is much ashamed to meet her, and he goes away at once. She stays in his house for three days, and when she leaves she is presented with a silk kerchief, sugar, money, or a sheep. Some days afterwards the young husband quite empty-handed pays an evening call to his father-in-law. $\mathrm{He}$ is received by his mother-in-law, who offers him some milk to drink, and then kisses his father-in-law on the head without saying a word in answer to his greeting. He shows very great bashfulness and goes away as soon as he has had his supper.

Later on the young couple together go to visit the wife's parents, but this visit is preceded by some interesting ceremonies which take place on the fortieth day after the arrival of the bride, nhar l-drbain. Accompanied by her mother- and brother-in-law, the young wife goes in the afternoon of that day to the thicket to procure fuel. She removes her girdle and slippers and puts the former on the heap of cut wood, so that the last bas shall go there and subsequently be burned. She then belts herself again and carries away the wood barefooted. When they approach the village she passes her load on to her mother-in-law's back and puts on her slippers. On her entering the house her sister-in-law, or some other unmarried girl who lives there, sprinkles water over her and puts on her a pair of new slippers and a new girdle instead of the old ones, which she has been wearing since her wedding, and which are now given away to some poor woman, 
as they must never again be used by the wife. I was told that the object of this ceremony, also, is to remove her bas. When her husband comes home in the evening she takes off his slippers and puts them over her own and thus goes and fetches a new pair for him, which she slips on his feet; this is supposed to make the young couple friendly to one another and to prevent divorce. The old slippers are given away to some poor man. The husband now slaughters a sheep or goat in the presence of his wife only, who assists him by keeping her hand on the animal's throat, and with its blood they seven times paint the heels of their feet (which during the wedding were covered by the backs of their slippers), so that the bas shall go away from them. Half of the meat is served with tăcam (sěksu) at the supper, in which the schoolmaster and scribes and some shereef of the village partake as invited guests, and after the meal fâtsha is made. The same evening the husband goes and hangs the lungs and heart of the slaughtered animal at a sîyid near by, and brings from there some earth to be suspended at his wife's belt to keep it "clean." When the guests have gone, the girl who sprinkled water on the young wife opens her hair, washes it with hot water into which she has put pounded qrónfél and sënbel, combs it, and does it again into two plaits; she then fumigates herself with harmel underneath her clothes, which reminds us of the earlier precautions taken when the hair of the bride was plaited.

1 Cf. Wuttke, Der deutsche Volksaberglaube der Gegenwart (Berlin, 1900), § 570, p. 376:- "Die ersten Schuhe, welche die junge Frau abreisst, dürfen nicht weggegeben, sondern müssen weggeworfen werden, sonst wird sie unglucklich." 
She is accompanied to the door of her room by the young wife carrying a burning lamp or candle, and when she enters the room the young wife blows out the light_ " to blow out the jnunn," as I was told-and goes in darkness to her husband. Next morning the wife boils the other half of the meat in water which has been in the house over-night, and with fuel from the wood procured by her the day before, thereby boiling and burning away the bas. This meat is then put into a dish ( $\left.g d^{\prime} s^{\prime} a\right)$ of $t \tilde{c}^{\circ} a m$ and taken by the young couple to the wife's parents, with whom they are now going to spend six days in succession. During the first three nights they do not sleep together. On the fourth day the wife's mother smears henna mixed with a little salt on her daughter's hands, feet, and hair, and paints her eyes with antimony, her lips with walnut root, and her cheeks with ochre; and this painting with antimony, walnut root, and ochre is repeated the two following nights. She now sleeps with her husband for the rest of the time, and has every day a hot bath in a little enclosure made for this purpose, the so-called hadmmam n-nwalla. The mixing of salt with the henna, which is practised only on the present occasion and at weddings, shows that the young wife is still supposed to be in danger of being struck by jnün.

Among the Ait Sádden the young wife is on the day after she was girdled taken to her father's house by her mother, who from the beginning of the wedding has been with her daughter during the day, and also spent the nights in the village if her own home is remote. 
The wife kisses her father on the head-a ceremony called asûd meat or some kind of bread or pastry - a present called țdrzzift. She stays in his house for a night or two, and when she leaves he gives her a sheep or cow, or perhaps even more than one, or a sum of money-a gift which is named asêfüd because she is "sent off" with it. If she has no mother she is accompanied by her motheror sister-in-law. The young husband, on the other hand, waits a month or more before he visits his fatherin-law, or does not call on him at all ; and if he goes he takes no present with him.

Among the Ait Yúsi the wife visits her parents the day she has been girdled if they live in the neighbourhood, otherwise later on; and she stays with them for a day or two. She gives them as tárzzift some hartêța - that is, pancakes made of flour and butter but without sugar-or something else of the kind. She is accompanied by her mother-, sister-, or brother-in-law, but not her husband, who neither visits nor speaks to his parents-in-law for a considerable time, perhaps a couple of years.

Among the Ait Nderr the husband and wife go together to the parents of the latter on the day after she has put on her belt or later; if they live far away the visit may even be postponed till a much later date. The young couple give the old folk a tatrzeft of nice bread and dried fruit, kiss them on the head, and remain with them for a day or two or longer. A portion of the bread and fruit, however, is distributed 
among the people of the village to give them the benefit of the baraka of the young wife. Before her departure her father presents her with a ewe or she-goat, or money to buy one-the animal must be a female that it shall give birth to young ones, and thus increase her private property; and her mother gives her some bread made with butter and dried fruit, if she has any-a present which is also called tatrzeft.

Among the Ait Warain the newly-married couple pay a visit to the wife's parents a fortnight after she has been girdled, taking with them as presents a slaughtered sheep, flour, and butter. On their arrival they are received by the mother with a bowl (táqnust) of milk, of which they drink, holding the bowl with both hands; this is said to bring good luck. The young husband kisses his father- and mother-in-law on the head and presents to the latter a dollar or two. A feast is given with other relatives as invited guests. This visit, which is called tárrzeft, lasts for three days.

Among the At Ubáhti the visit to the wife's parents takes place as soon as she has been girdled, or on the young husband's return from his tour to other villages. They are accompanied by his mother and the áuzir. The husband takes with him presents of sugar and tea and a live sheep, which he slaughters on their arrival; and both he and his wife kiss the heads of her parents. Next morning he and the auzir go away, whereas his wife and mother remain with his parents-in-law for two or three days more. When they leave they are pre- 
sented with some tísargit (thin bread made with salt butter) and a portion of the slaughtered sheep, raw or boiled, which they take away with them. This present is called tamdwilt.

Among the Ait Wäryâgäl, when the forty days mentioned above have come to an end, the husband slaughters a goat, and the wife boils its meat in oil and makes a lot of bread. They then load the meat and bread on two mules and take it to the wife's parents. Of the bread they must give a loaf to every party of people, and half a loaf to every single person, whom they meet on the road. Should they refrain from doing so, the people they met would make a cairn, thrust a cane with a flag into it, and dung over the stones; this is looked upon as a powerful curse, which will probably make the couple childless. Subsequently the wife's father gives a loaf of the bread to each household in the village, for there is baraka in it. The husband kisses his parents-in-law on the crown of the head; he is very bashful, and only speaks to them in a low voice. After a couple of days he goes away, whereas his wife stays with her parents for a whole month, and then he comes back to fetch her. At their departure her parents present her with a cow or some goats and a lot of bread, of which she gives a loaf to each household in her husband's village. The present given to her parents is called ditrzeft, and so is also the bread which they give to her.

Among the Ait Támelldu a whole year passes before the couple pay a visit to the wife's parents. They take 
with them a present of bread, dates, and henna, and kiss the old folk on the head. The husband goes away in the evening; the wife, on the other hand, remains with her parents for two or three days.

There is commonly much reserve in a man's relations to his parents-in-law and other members of his wife's family. In Aglu he kisses his mother-in-law on the head when she comes to his house a few days after the fetching of the bride, but he refrains from speaking to her for some time ; and even in the future he generally avoids both her and his father-in-law, neither speaking to them much nor eating with them. Among the Igliwa, also, the bridegroom kisses his mother-in-law on the head when he first meets her after her arrival at his house, but shows much bashfulness in her presence. In the beginning he must not speak to her, and he can never eat with her, unless she comes and lives with her daughter in his house. So also he for some time refrains from speaking to his father- and brothers-in-law, and even later he never eats with them, nor is he seen together with them in public; should any of them come where he is sitting with other persons, he at once gets up and leaves the company. If a man meets a friend whom he has not seen for a while, he jokingly says :-Maḩ átèrggult fillî, isak ${ }^{y}$ gi ddüggal;" "Why have you been running away from me, am I your brother-in-law ?" Among the Ait Nder a married man does not eat with his father-in-law, and is also shy of his mother-in-law, though he is allowed to 
see her face. Among the Ait Warain, I was told, he is even shyer of his mother- than of his father-in-law. Among the Ait Wäryâgäl he speaks to his parents-inlaw but does not sit together with them if they meet outside their own houses, and when he meets them he pulls the hood of his cloak over his face. There are similar customs among the Arabic-speaking tribes. In Andjra, it is true, a man may both talk and eat even with his mother-in-law, but he is shy of her and the rest of her family, and must speak no improprieties in the presence of either his parents- or brothers-in-law ; and if an indecent conversation is carried on when his father-in-law is present, he must leave the company. Among the Ulâd Bu-Ăzîz a man refrains from eating together with or in the presence of his father-, mother-, or grown-up brother-in-law, if they are of another village. If, on the other hand, his father- and brothersin-law are of his own village, he is not ashamed to eat with them, but there must be no indecent talk in their presence; in case anything indecent is said; he goes away at once, and if it has reference to himself he may even complain of it to his governor, with the result that the offender is compelled to pay a fine. He has much respect for his father-in-law; there is a saying that, if a man has no saint in the place where he is living, his father-in-law is his saint_Li ma 'áddu fqër nsîbu hûwa fqêru. Between a man and his mother-in-law there is mutual shyness. They speak to each other, but not much, and only sensible words-l-kläm l-ma'qol; if they are from different villages they avoid looking at each 
other, while if they are from the same village she covers her face and refrains from eating in his presence, though he may eat in hers. In the Hiáina a man does not speak to his parents-in-law if his own parents are alive, otherwise he begins to converse with them when a month or so has passed. He is still shyer of his father-in-law than of his mother-in-law, and also avoids a grown-up brother-in-law. At Fez, on the other hand, the intercourse between a married man and his father- and brothers-in-law is not subject to any special restrictions, but for a couple of years after the wedding he avoids meeting his mother-in-law; if she comes to his house to see her daughter he must retire, although he may speak to her from a distance. $\mathrm{He}$ is called the $n s i b$ of his father-, mother-, and brothers-in-law, and of his wife's paternal and maternal uncles; each of these persons is also his $n s i b$ or, in the case of his mother-inlaw, nsîba, and collectively they are his $n s \bar{a} b$. Another name for them is $l i d-h t^{s} \vec{a} n$. In the Hiaina a husband is the $n s i b$ of all the persons, men and women, who belong to his wife's community, whether related by blood or not, and they on their part are his nsab.

I was told that a man would naturally be shy of the persons with whose daughter or sister he has sexual intercourse, and this I take to be the true explanation of the restrictions in question. I believe that they ultimately spring from that feeling of sexual aversion which prevails between members of the same domestic circle, with the exception, of course, of husband and wife. This aversion, to which I trace the customs and 
laws prohibiting incest, ${ }^{1}$ has also, in my opinion, been the chief cause of the feeling of sexual shame, which is particularly strong precisely inside the family but, owing to the influence of early sentiments and taboos, has extended far beyond its limits, throwing a veil of secrecy over sexual relations in general. Especially in a country where the sexes are separated from each other to such a degree as they are in Morocco, the mutual relations into which a man and woman enter by their marriage are looked upon as something to be ashamed of, and this feeling of shame would naturally display itself very acutely in the presence of persons who would not only at once come to think of those relations but feel aversion to the very idea of them. It seems to me quite clear that the young man's shyness of his parents-in-law is psychologically connected with his shyness of his own parents in all matters relating to his marriage. This shyness shows itself from the moment when the marriage is first thought of till the wedding has passed and even longer. We have seen that there is no conversation on the subject between the young man and his parents, or at least his father, and that he sometimes entirely avoids the latter from the day when the arrangements for his marriage commence. ${ }^{2}$ At Fez the father keeps away

1 See infra, p. 370 sqq.

2 Cf. Menouillard, 'Un Mariage dans le Sud Tunisien (Matmata), in Revue Tunisienne, ix. (1902), p. 372 :- "Le fiancé est mis au courant huit jours avant la célébration du mariage, par des amis de son âge, des dispositions arrêtées entre parents ; il quitte alors la maison paternelle, car dès ce moment, par pudeur et par respect, il ne doit pas se montrer à ses parents, et cette interdiction dure encore pendant plusieurs mois après son mariage. Il va cacher dans les jardins, où ses amis lui apportent à manger et viennent lui tenir compagnie." At Qalà' of the Beni Rached, in Algeria, it is an old custom that "le fils nouveau marié évite son père durant les 
from his son's wedding; on the great occasion when the bridegroom, after the arrival of the bride, comes to dar l-örs to meet her, his father hides himself somewhere in the house or in another house, or stays in the street. Sometimes the bridegroom puts off his first intercourse with the bride till all the guests have gone away, or till the evening of that day, because he is shy of his parents. ${ }^{1}$ Among the Ait Yúsi, if he lives in the same tent as his parents or one of them, he will, out of bashfulness, stay away during the day even for a whole month, taking his meals somewhere else and visiting his wife only at night; and here, as in many other tribes, he resumes his intercourse with them by a special ceremony, that of kissing their heads. Among the Ait Sáddenn, on the day when the bride has been girdled, he is taken to his parents' house by a procession of men and women, who are playing on tambourines, singing, and dancing; accompanied by the two imsnein, he enters the house with the hood of his cloak still drawn over his face, and kisses them on the head. Among the Ait Nderr, after the young husband has returned from his excursion on the evening of the day when his wife has belted herself, he enters his parents' tent in the company of his "vizier" and another bachelor, all

deux ou trois mois qui suivent son mariage" (Gaudefroy-Demombynes, in Revue des traditions populaires, xxii. [1907], p. 55. Cf. Idem, Les Cérémonies du mariage cher les indigènes de l'Algérie [Paris, 1901], p. 75 [Tlemcen]). Among the Beni Snüs, whilst the young wife sees her parents-in-law as soon as she has resumed her girdle, her husband "reste encore trois ou quatre jours sans oser paraître devant son père et revant sa mère. Puis il vient les embrasser à son tour" (Destaing, Étude sur le dialecte berbère des Beni Snous [Paris, 1907], p. 290).

1 Supra, pp. 249, $25^{2}$ sq. 
three with the hoods of their cloaks pulled over their faces, and one after the other they kiss the parents' heads; he is too bashful to appear alone, nay for some days afterwards he still shows great shyness of his parents. Among the Ait Warain it is the custom that the young husband does not show himself or speak to his parents till some three weeks have passed, when he kisses their hands. This custom is not always observed, but as a rule a son is so shy of his father that he avoids him for a considerable time, "even as long as forty days," after his wedding; and when his wife becomes a mother he never holds the child in his arms in the presence of his father. $\mathrm{He}$ is less shy of his mother than of his father, whereas he is more shy of his motherin-law than of his father-in-law. There is also bashfulness in the relations between the bride and her parents. ${ }^{1}$ In Andjra she does not see them as long as the wedding lasts. Among the Ait Sádden and at Fez, as we have noticed, the "girl avoids her father at the time of the betrothal, and nowhere in Morocco does the father go to his daughter's wedding. In some places her mother also stays at home, and the same may even be the case with her grown-up brothers.

If, as I believe, the husband's avoidance of his parents-in-law is ultimately based on the sexual shame felt inside the domestic circle, it may be asked why his avoidance of his own parents should be of a much

1 Cf. D'Arvieux, Travels in Arabia the Desart (London, 1718), p. 235 :-_" All the relations assist at the wedding, except the bride's father, who leaves the house that evening out of an odd piece of niceness that will not suffer him to be at home whilst they are putting his daughter to bed with a man. The fathers make this a point of honour." 
shorter duration, although it is a more direct expression of the feeling which is at the bottom of both customs. The answer, however, is not difficult to find. There is no feeling which is more easily influenced by habit than shame, and it would be difficult for the son to avoid his own parents for long, living as he does in their vicinity, if not under the same roof, and having so many interests in common with them. It is worth noticing that there is much less restraint in a man's relations to his parents-in-law if they live in his own than if they live in another village, and that his avoidance of them soon ceases if his own parents are dead, and there consequently is more inducement for him to attach himself to his wife's family than would otherwise be the case. ${ }^{1}$ It

1 These facts are at variance with Sir E. B. Tylor's conclusion that the avoidance between a man and his wife's family is intrinsically connected with the custom of the husband taking up his abode with the latter. He argues as follows :- "If the customs of residence and the customs of avoidance were independent, or nearly so, we should expect to find their coincidence following the ordinary law of chance distribution. In the tribes where the husband permanently lives with his wife's family (sixty-five out of three hundred and fifty), we should estimate that ceremonial avoidance between him and them might appear in nine cases, whereas it actually appears in fourteen cases. On the other hand, peoples where the husband at marriage takes his wife to his home (one hundred and forty-one out of three hundred and fifty), would rateably correspond with avoidance between him and her family in eighteen cases, whereas it actually appears in nine cases only" (Tylor, 'On a Method of Investigating the Development of Institutions,' in The Fournal of the Anthropological Institute, xviii. [1889], p. 247). This argument, however, suffers from a very serious defect. The fact that the avoidance in question has been noticed in a comparatively large number of tribes where the custom is for a man to reside in his wife's family, by no means proves that it really is less common in tribes whose habit it is for the husband to take her to his own home; for it would naturally be much more conspicuous in the former cases than in the latter. Hence $I$ do not think Sir E. B. Tylor has successfully interpreted the custom of avoidance by saying that, "as the husband has intruded himself among a family which is not his own, and into a house where he has no right, it seems not difficult to understand their marking the difference between him and themselves by treating him formally as a stranger" (ibid. p. 248). Nor is there any foundation for Lord Avebury's hypothesis that the avoidance between parents-in-law and son-in-law is a conse- 
is true that his avoidance of his parents-in-law may also have something to do with the fact that he has deprived them of their daughter; but many of the statements all the same show that this avoidance is essentially connected with sexual shame. The same is obviously the case with the mother-in-law's avoidance of her son-inlaw, whose presence is apt to call forth associations of ideas that make her blush both as a woman and as a mother.

There is no special avoidance noticeable in the relations between a wife and her parents-in-law. In some places at least it is the custom that she, as soon as she has been girdled, kisses them on the head. Among the Ait Warain after the girdling she kisses her fatherin-law's head and hands and he gives her a silk kerchief, whereas her husband, as we have seen, avoids him for another couple of weeks. She addresses her father-in-law sîdi, "my lord," and her mother-in-law lálla, "my lady"; but when she becomes more familiar with them she calls the former amgarinü, "my sheik," and the latter tamgartînu, " my mistress." Among the

quence of marriage by capture (Avebury, The Origin of Civilisation [London, 1912], p. 103); this form of contracting marriage has played a much more prominent part in the imagination of anthropologists than in the life of savages. According to Mr. Fison, the mutual avoidance of mother-in-law and son-in-law is due to a fear of intercourse which is unlawful and to the consequent idea that the slightest familiarity between them would be indecent (Fison and Howitt, Kamilaroi and Kurnai [Melbourne, \&c., 1880], p. 103 sq.) ; whilst Mr. Crawley (The Mystic Rose [London, I902], p. 408) thinks that this avoidance is "causally connected with a man's avoidance of his own wife," being part of the system of sexual taboo, which contains "amongst other things mutual avoidance between engaged couples, and between the married man and his wife." The most obvious weakness in these two explanations is that they do not take into account the frequent avoidance between a man and his father-in-law. 
At Ubáhti a married woman, in speaking to her fatherin-law, calls him 'ámmi, "my paternal uncle," and her mother-in-law she addresses hadlti, " my maternal aunt." Among the Arabs of the Hiáina the husband's father is his wife's Yeh, "sheik," and his mother is called by her lä-'güza, "the old woman," but when she speaks to them she addresses them sîdi and lálla respectively; they on their part call her their bents, "daughter." At Fez the husband's father is his wife's $h m \hat{u}$, his mother is her $h m a$, his brother her $l \bar{u} s$, and his sister her lûsa. 


\section{CHAPTER X}

\section{SUMMARY AND EXPLANATIONS}

$\mathrm{W}_{\mathrm{E}}$ have noticed a great variety of superstitious beliefs and practices connected with Moorish marriages.

Sometimes divination is resorted to by the young man's mother in choosing a suitable wife for her son. ${ }^{1}$ Sometimes the girl prevents a betrothal which she finds objectionable by making use of bad and ominous words or by behaving like a woman at a funeral. ${ }^{2}$ The transference of conditional curses by means of $a r$-sacrifices is a common method of bringing about a betrothment $;^{3}$ and even when no such sacrifice is made it is considered bad if the girl's father or parents persist in refusing a proposal. ${ }^{4}$ In some Berber tribes the fear of liar has led to a custom which makes it possible for a married woman to run away from her husband and, by taking refuge in another man's dwelling, compel the latter to marry her. ${ }^{5}$

The wheat which is to be used for the wedding, and which has been cleaned in the bridegroom's house,

\footnotetext{
1 Supra, p. 32.

3 Supra, pp. 35, 38, 42, 45, 46, 5 I.

5 Supra, p. 60 sqq.
}

4 Supra, pp. 28, 45. 
must not be taken to other houses to be ground; for it would be bad to do at a wedding what is regularly done at a funeral ${ }^{1}$ - a feeling which also prevents honey being served at a wedding. ${ }^{2}$ On the other hand, it is supposed to bring good luck if the bachelors who are present on the occasion when the wheat is cleaned and ground now and then take part in the grinding and singing. ${ }^{3} \quad$ A superstitious importance is attached to the grit which has been removed from the wheat; it is put in a clean place so as not to be defiled, ${ }^{4}$ or it is thrown on the floor of the bridegroom's dwelling in order that the wedding shall be attended by many guests, ${ }^{5}$ or the bridegroom casts it together with dried fruit on the bride when she approaches the door of his house, ${ }^{6}$ or it is disposed of in some other manner still to be mentioned.

Marriages are avoided in certain periods, ${ }^{7}$ and are by preference or invariably celebrated on certain days of the week. ${ }^{8}$ In one tribe it is considered a good omen if the bride arrives at her new home at the same hour as the flocks and herds return from the pastures. ${ }^{9}$ There is much omening at weddings. When the bride has been painted with henna, it is an evil foreboding if the painted parts become very red when they are rubbed clean the next morning. ${ }^{10}$ When the animal which is going to bear her to her new home is taken to her parents' dwelling, it would be a bad omen if it went

1 Supra, p. 9 r.

4 Supra, p. 89.

7 Supra, p. 86.

10 Supra, p. 137.
2 Supra, p. 23 n.

5 Supra, p. 95.

8 Supra, p. 86 sq.
3 Supra, pp. 92, 94.

6 Supra, Pp. 95, 214.

9 Supra, p. 175. 
there with an empty saddle $;^{1}$ and empty dishes, trays, or tables, are likewise avoided at weddings, ${ }^{2}$ as on certain other occasions. $^{3}$ When the bride has arrived at the bridegroom's place, there are omens indicating whether the husband will rule over his wife or the wife over her husband, ${ }^{4}$ whether their conduct will be straight, ${ }^{5}$ whether the wife will remain with her husband or there will be speedy separation, ${ }^{6}$ whether she will be domineered by her mother-in-law or vice versa, ${ }^{7}$ and so forth. ${ }^{8}$

A very large number of marriage ceremonies spring from the feeling or idea that bride and bridegroom are in a state of danger, and therefore stand in need of purification and of special protection against magical influences and evil spirits. To this class of customs belong avowedly or presumably, at least in part; the bathing and washing of bride or bridegroom, ${ }^{9}$ and other water ceremonies; ${ }^{10}$ the shaving of the bridegroom, ${ }^{11}$ and the dishevelling of the bride's hair $;{ }^{12}$ the assumption of new clothes and slippers $;^{13}$ the painting

1 Supra, pp. 172, 180, 182, 192.

2 Supra, pp. 24, 25, 34, 239, 241, 249, 279, 287.

3 Westermarck, Ceremonies and Beliefs connected with Agriculture, certain Dates of the Solar Year, and the Weather in Morocco (Öfversigt af Finska Vetenskapssocietetens Förhandlingar, Bd. liv. 191 1-1912, Afd. B. N:o. I), p. $3^{8}$.
4 Supra, pp. 205, 252.
${ }^{6}$ Supra, pp. 208, 209, 247 sq.
5 Supra, p. 209.
7 Supra, p. 299.
8 Supra, pp. 200, 205.

9 Supra, pp. 11 8, 120, 126, 127, 136, 140, 141, 144, 146, 149, 153, 155, 156, $161,162,228,232,266,277,296-298,301-303,305$ sq.

10 Supra, pp. 97, 1 $21,122,126,128,144,162,231,232,255,304$.

11 Supra, pp. 102, 106, 120, 127, 130, 131, 133.

12 Supra, pp. 148, 169, 172, 247, 261, 264, 291.

13 Supra, pp. 102, 120, 128, 146, 148, 1 50, 152-154, 156, 175, 194, 225, 275, 304 . 
with henna, ${ }^{1}$ antimony, ${ }^{2}$ and walnut root or bark, ${ }^{3}$ and, in the case of the bride, with saffron as well $;^{4}$ the purification with flour, ${ }^{5}$ bread, ${ }^{6}$ wheat, séksu, or $t \xi_{i} \zeta^{4} a ;{ }^{7}$ the use of candles ${ }^{8}$ the burning of incense $;^{9}$ the firing off of guns $;^{10}$ the loud music ${ }^{11}$ and singing, ${ }^{12}$ and the quivering noise of women ${ }^{13}$ the use of salt, ${ }^{14}$ needles, ${ }^{15}$ steel-weapons-like daggers ${ }^{16}$ and swords ${ }^{17}$ and pistols ${ }^{18}$ the wearing of various other charms, for example, silver coins $;^{19}$ the making of the bridal box of oleander branches ${ }^{20}$ the hiding or covering of the face ${ }^{21}$ the shutting up of the bride in a

I Supra, pp. 95, 97-102, 105, 107-120, 136, 137, I41, 142, 144-151, 153-158, $160,161,242,295,303,306$.

2 Supra, pp. 105, 153,193, 233, 242, 266, 282, 283, 295, 306.

3 Supra, pp. 105, 1 53, 193, 242, 266, 282, 283, 295, 306.

4 Supra, pp. 152-154, 242, 243, 266, 295.

5 Supra, pp. 103, 104, 119, 153, 162, 194, 195, 197, 207, 208, 214, 216 sq.

8 Supra, pp. 292, 295. 7 Supra, pp. 197, 217.

8 Supra, Pp. 97, 98, 121, 122, 130, 132, 136, 139, 144, 145, 162, 166, 187, 226, 23 x, 248, 252, 292, 295.

9 Supra, pp. 235, 237, 244, 255, 305.

10 Supra, pp. 41, 44: 45, 48, 50, 78, 89, 92-96, 108, 109, I11, I12, I14, I15, I17, I 22, 123, 128, 130, 1 $31,145,162,169,170,173,174,177,179,181-183,185,188$, $195,197,204,210,211,214,218,281$; shots fired on the consummation of the marriage, supra, pp. 233, 236, 237, 240, 242, 245, 249, 251, 253, 266 sq.

11 Supra, especially pp. 122, 162, 188, 218, 294, 297.

12 Supra, especially pp. 162, 188, 267.

13 Supra, pp. 25, 33, 35, 41, 44, 45, 48, 50, 67, 78, 89, 103, 104, 107, 109, 112, $122,129,136,138,140,148,155,162,173,174,182,183,188,194,195,197$, $218,226,294,296$ sq.; quivering noise made on the consummation of the marriage, supra, pp. 228, 233, 236, 237, 240, 242, 245, 249, 253, 267, 269.

14 Supra, pp. 89, 90, 103-105, 123,147, 1 50, 162, 166, 187, 251, 256, 296, 306.

15 Supra, Pp. 150, 162, 237, 256, 290.

16 Supra, pp. 89, 123, 152, 163, 197, 211,22 1.

27 Supra, pp. 97 n., 99, 102, 104, 106-109, I11, I12, 123, 149, 155, 162, 235, 237, 239, 242, 244, 251, 255, 282, 290.

18 Supra, pp. 112, 123, 248, 255, 290.

19 Supra, pp. 104, 105, 123, 147, 162, 163, $290 . \quad 20$ Supra, p. 168.

21 Supra, pp. 97, 102, 105, 106, 108, I 11, 1 12, 114, 123, 128, 131, 137, 138, $142,147,148,152,156,163,172,174,179,181,184,185,189,196,198,203$, $212,219,225,233,239,250,254,266,282,283,287,289,296,299,314$ sq. 
box ${ }^{1}$ the dressing-up of the flance as a bride, ${ }^{2}$ and the bride's imitating the appearance of a man $;^{3}$ her walking with women dressed like herself $;^{4}$ the pullingup of the backs of the slippers $;^{5}$ the keeping-on of the slippers at night $;^{6}$ the beating, smacking, or tapping of the bride or bridegroom $;^{7}$ their throwing of a slipper at each other $;^{8}$ the destroying or removing l-bas by blowing to pieces, ${ }^{9}$ breaking, ${ }^{10}$ crushing, ${ }^{11}$ cutting, ${ }^{12}$ burning, ${ }^{13}$ boiling, ${ }^{14}$ or throwing away ${ }^{15}$ some object; the pelting with stones ${ }^{16}$ dancing; ${ }^{17}$ incantations against the devil ${ }^{18}$ prayers, ${ }^{19}$ recitations from the Koran, ${ }^{20}$ the singing of religious songs, ${ }^{21}$ and the performance of other ceremonies of religious import $;^{22}$ and various abstinences, such as from leaving the dwelling, ${ }^{23}$ from eating much, ${ }^{24}$ from eating and drinking in public, ${ }^{25}$ from speaking or speaking aloud, ${ }^{26}$ from

1 Supra, pp. 166-1 68, 189.

2 Supra, p. 25.

3 Supra, pp. 27, 152, 153, 163, 174, 187 sq.

4 Supra, pp. 27, 165, 187; $f f$. p. 198.

5 Supra, pp. 102, 109, 1 1 1, I1 2, 1 14, 123, 124, 147-150, 156, 159, 163, 251 , $253,254,266,290$.

6 Supra, pp. $239,290$.

7 Supra, pp. 104, 107-109, 120, $121,157^{-159,162, ~ 198, ~ 199, ~ 214, ~ 217, ~ 223, ~}$ $235,237,244,248,250,252,256$ sq9.

8 Supra, pp. $251,256$.

9 Supra, pp. 91, 245, 267.

10 Supra, pp. 99, 101, 108, 109, 121, 131, 149, 162.

11 Supra, pp. $235,256$.

13 Supra, pp. 304, 306.

12 Supra, pp. 235, 237, 256.

15 Supra, pp. 197, 237, 256.

14 Supra, p. 306.

17 Supra, pp. 98, 101, 110, 121, 137, 145, 149, 162, 206; dancing on the consummation of the marriage, supra, pp. 236, 240, 241, 25x-253, $267 \mathrm{sq}$.
18 Supra, p. 98.
19 Supra, pp. 130, 231, 232, 244, 250, 251, 255, 266.
20 Supra, pp. 198, 199, 232, 255, 266.
21 Supra, pp. $98,100,126,129$.
22 Supra, pp. 129, 186, 200, 205, 208, $214,218$.
23 Supra, pp. 117, 123, 156, 157, 163, 281, 286, 289, $291,300$.
24 Supra, pp. 99, 123, 144, 196, 212.
25 Supra, pp. 99, 123, 130, 203, 207, 221, 234, 240, 241, 273.
26 Supra, pp. 129, 203, 207, 21 2, 221, 234, 244, 253. 
falling asleep, ${ }^{1}$ from turning the head and looking back, ${ }^{2}$ from bathing or washing ${ }^{3}$ or having the head shaved ${ }^{4}$ or changing clothes ${ }^{5}$ for a certain length of time, from wearing a girdle, ${ }^{6}$ from sitting on the ground, ${ }^{7}$ from treading on the ground or the threshold, ${ }^{8}$ and, in the case of the bride, from the crossing of open bridges. ${ }^{9}$ As a protection against magic the grit removed from the wheat which is to be used for the wedding is thrown into a river, water-course, or spring, or buried in the ground $;^{10}$ the bridegroom steps three times over the bundle of old clothes containing his shaved-off hair ; ${ }^{11}$ the bride is carefully guarded by women on her way to the bridegroom's place, particularly for fear lest some malevolent person should in a magical manner deprive her of her virginity $;^{12}$ she shakes out the henna-powder from her slippers and throws it into water $;^{13}$ and when the young wife pays her first visit to her parents she goes and comes back in the evening, being still very susceptible to the evil eye. ${ }^{14}$ Superstitious fear is also at the bottom of the rules that the bride must not be spoken to, ${ }^{15}$ that the bridegroom should put his right foot twice over the threshold of the nuptial chamber

\footnotetext{
1 Supra, pp. 237, 254.

3 Supra, pp. 114, 115, 290.

2 Supra, pp. 172, 189, 231, 250, 255.

5 Supra, pp. $115,291$.

6 Supra, pp. 146, 148, 225, 237, 263, 264, $281,293$.

7 Supra, pp. 25, 27, 100, 102, 103, 105, 106, $115,123,130,132,139,142,227$.

Supra, pp. 109, 110,123, 130, 132, 133, 141, 144, 145, 148, 163, 168, 169, 172, 174-176, 179, 181-189, 195-198, 201, 205, 207, 208, 210, 212, 214, 219 sq.

9 Supra, pp. 166, 187.

10 Supra, p. 91 sqq.

11 Supra, p. 230 sq.

13 Supra, p. 150.

15 Supra, p. 203.

4 Supra, p. 290.

12 Supra, pp. 172, 173, 175, 176, 179, 185, 188. 14 Supra, p. 302 sq.
} 
before he makes his entrance by a third step, ${ }^{1}$ that the candle or candles burning there must not be extinguished by anybody, ${ }^{2}$ that the slippers worn by the bride or bridegroom must never be repaired, ${ }^{3}$ and that the slippers and girdle which the bride has worn since the wedding must be removed on the fortieth day, and never again be used by her. ${ }^{4}$ The sacrifice performed on the girdling of the bride, ${ }^{5}$ and the money which the bridegroom gives her immediately before or after their first intercourse, ${ }^{6}$ or on plaiting her hair ${ }^{7}$ or on undoing the end of one of her plaits ${ }^{8}$ or on girdling her, ${ }^{9}$ seem to have a prophylactic origin ; and $I$ am further inclined to ascribe a purificatory significance to the ceremonial fights and sham robberies which take place at the wedding and in some cases centre round the bride or bridegroom.

The bride, however, is considered to be not only herself in danger but also a source of danger to others. Customs that have direct reference to her may at the same time be looked upon as safeguards against evils which threaten the bridegroom, as is evidently the case with various ceremonies which immediately precede the consummation of the marriage. Moreover, customs that are supposed to protect or purify the bride may also be practised for the purpose of protecting other persons less intimately connected with her than is her husband. Thus she has her face well covered, or she is shut up in

1 Supra, pp. 251,254 sq.

3 Supra, p. $29^{\circ}$.

2 Supra, p. 252.

6 Supra, pp. 11 3, 159, 237, 239, 241, 242, 244, 248, 251, 253, 262 sq.

7 Supra, pp. 248, 261.

${ }^{8}$ Supra, pp. 261 n. I, 276.

5 Supra, p. 294 sq.

4 Supra, p. 304 sq.

9 Supra, p. 294. 
a box, not only to be sheltered from the evil eye, but also because her own glance or the sight of her is considered injurious to others. ${ }^{1}$ The pelting of her with stones when she leaves her old home is sometimes said to rid her of her evil, ${ }^{2}$ and sometimes to cause her to take her evil with her, ${ }^{3}$ or to remove all the evil from the village. ${ }^{4}$ The sprinkling of the bride with milk or a mixture of henna and water, when the bridal procession passes a village, is in one instance explained as a method of averting evil from the village ${ }^{5}$ and the ceremonies which precede or are connected with the bride's arrival at the bridegroom's place are largely intended to prevent her carrying evil with her to her new home. It is presumably for this purpose that she, on her way thither, is taken to a river which she has to cross on her mule three times to and fro, ${ }^{6}$ and that, if the procession passes a shrine, she has to ride round it three times and fatha is made. ${ }^{7} \quad$ For a similar purpose she is taken three or seven times round the bridegroom's house or tent ${ }^{8}$ or the mosque of his village ${ }^{9}$ or the village itself $;^{10}$ purifying substances, like milk, ${ }^{11}$ water, ${ }^{12}$ and henna, ${ }^{13}$ are offered her or sprinkled on her ; an egg which has been dipped into milk and flour is thrown at the forehead of the mule ridden by her in

1 Supra, pp. 148, 163,169, 172, 181, 189, 219.

2 Supra, pp. 171, 190.

4 Supra, pp. 176, 177, 190.

6 Supra, pp. $185,190$.

8 Supra, pp. 196-198, 200, 206, 209, 215.

9 Supra, pp. 199, 200, 203, 208, 215.

3 Supra, pp. 170, 190.

5 Supra, pp. 177, 178, 190 sq.

7 Supra, pp. 185, 186, 190.

11 Supra, pp. 194, 203, 207, 210,212 sqq.

10 Supra, pp. 203, 215.

12 Supra, pp. 203, 209, 212, 215 sq.

13 Supra, pp. $214,217$. 
order that "she shall bring no evil with her;" ${ }^{1}$ and the wheat, flour, seksu, or $i \xi_{i} \imath^{*} a$ which is given her and which she casts over her head is represented as a means by which she rids herself of evil influences. ${ }^{2}$ For the express purpose of expelling evil she beats the bridegroom's tent three times. ${ }^{3}$ The animal which she has ridden is purified in some way or other, ${ }^{4}$ and the saddle used by her is smeared with henna or blood. ${ }^{5}$ Before she is carried into the bridegroom's tent guns are fired off close to her in order to prevent her evil influences from affecting the islän, that is, the bridegroom's bachelor friends. ${ }^{6}$ The ceremonial wedding fights may serve a prophylactic or cathartic object for all who engage in them $;^{7}$ and as for the dung of animals used in one of these fights, ${ }^{8}$ and the porridge which the wedding guests smear on each other's faces, ${ }^{9}$ it is worth remembering that purifying qualities are attributed to these substances. ${ }^{10}$ It should also be noticed that the same kinds of purifying or protective matters as are applied to the bride or bridegroom are made use of by persons who come in close contact with them: the bridegroom's best-man or his bachelor friends in general smear henna on their hands or clothes, ${ }^{11}$ and paint their eyes with antimony and their lips with walnut root $;{ }^{12}$ and the same things, as well as saffron, are used by the

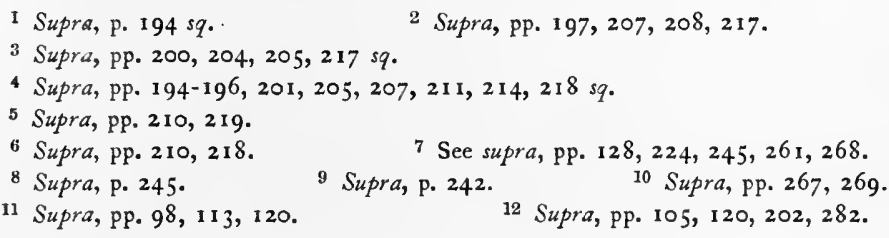


bride's girl-friends, and even by all the women who are present at the wedding. ${ }^{1}$ And in one tribe not only the bride, but the bridegroom's mother and the other women of his family, have their hair open during the wedding. ${ }^{2}$

Why are bride and bridegroom supposed to be in a dangerous condition, and why is the bride considered dangerous to others? In order to answer these questions it will be necessary for us to compare the ceremonies described above with those practised in cases where either bride or bridegroom or both have been married before. Such marriages are much more common in Morocco than in Europe, owing to the frequency of divorces and remarriages and the practice of polygamy. I once had in my service an elderly Berber from Sas who had had twenty-five wives, though never more than two at a time, and of these he had divorced twenty-two, and two had died. And divorced wives and widows have also a great chance of remarrying, as they are generally much cheaper than virgin brides, and there is a great demand for marriageable women-especially in Berber tribes where polygamy is much practised, owing to the prevalence of the bloodfeud, which makes it highly desirable for a man to have many sons. ${ }^{3}$

1 Supra, pp. 1 53, 156, 157, 161, 283.

2 Supra, p. 291.

3 I was told that among the Ait Waráin the desire for offspring even overrules male jealousy. A man who has no children is quite pleased if other men have intercourse with his wife or wives; he pretends to know nothing about it, and is assumed to be the father of any child resulting from such a union. So also a son whose father is dead is glad if his mother gives birth to a boy, even though she has no husband. 
At Fez, if the bride is a hajjâala, ${ }^{1}$ that is a widow or divorced wife, whilst the bridegroom is an 'azri, or bachelor, the feasting and ceremonies which in the case of a virgin bride take place in the house of her family are omitted, a meal only being served there with some relatives as guests. But from the moment when she is taken from her old home to dar l-örs the ceremonies to which she is subject are essentially the same as they would be if she had not been married before, and so far as the bridegroom is concerned the wedding is not at all influenced by her being a hajjâla. If, on the other hand, he has another wife or is a häjöal ${ }^{2}$ - that is, a man who has been married but is so no longer, either because his wife has died or because he has divorced her-and she is an ' $\hat{a} t^{5} a q$-that is, a grown-up woman who neither is nor has been married,-the marriage ceremonies are, in everything that has reference to her, exactly the same as if the bridegroom were a bachelor; whereas there is no där islän nor any sham court, as he is not now regarded as a sultan. If, finally, the bridegroom is not an 'ári, and the bride is not an 'ât'aq, there are no ceremonies at all, not even a festival meal; he simply sends a woman or two to fetch the bride at sunset.

Among the Ulâd Bu-Ăzîz, if the bride is a widow or divorced wife, she does not pull up the backs of her slippers, nor is she brought to her new home on a camel, but goes there on foot, nor has she to pass three times round the bridegroom's tent before entering it. But

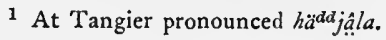

2 At Tangier pronounced hắd jäl.
} 
a camel is nevertheless brought to the bride's place, and a girl of her village is mounted on it. This girl is called "the bride," and is taken to the bridegroom's abode with the same ceremonies as if she were the real bride: she has her face covered, rides three times round the bridegroom's tent, is received there by his mother in the manner of a virgin bride, and is at last carried into the tent. She leaves it, however, soon after, and when the bridegroom and his two friends pass through the tent, as said above, it is the real bride that tries to smack them with the slipper. This, indeed, is only what may be expected, whether the ceremony in question is looked upon as a means of purifying the bridegroom or as an attempt on the part of the bride to become his ruler ; it should be noticed that in her old home also she had performed those magical acts by which brides endeavour to gain influence over their husbands. ${ }^{1}$ But, unlike a virgin bride, she only spends three or four days behind the curtain in the bridegroom's tent. The fact that the bride is a hajjâla does not affect the ceremonies to which the bridegroom is subject, in case he is a bachelor; but if he has another wife, or has had one before, these ceremonies are omitted, whether the bride has been married or not. He then neither covers his face with the hood of his cloak, nor pulls up the backs of his slippers, nor has his hand painted with henna, nor runs through the tent to be smacked by the bride; nor is there any recitation from the Koran made by 
scribes, nor does he go on a tour with. his bachelor friends. His mother does not carry a sieve on her back, and neither she nor the other women of his family loosen their hair, even though the bride has dishevelled hers. But he must stay with the bride for seven days, whether he has another wife or not. It may be added that if a man takes a second wife without divorcing the one he has, he must give to the latter the same $d h \bar{d} z$ as to the bride; and although the old wife is said to be very sorry, she entertains her female friends with a "wedding-feast."

Among the Brâber of the Ait Saddern a woman who has been married before ( $t{ }^{\prime d d}$ jalt) does not, like a virgin bride, perform the ceremony called izüd ohrir, consisting in her grinding wheat over her uncovered right thigh, nor is she painted with henna. She goes to her new home on foot, but is accompanied by a crowd of people, including men who are discharging volleys of gunpowder. On her arrival she goes round both the mosque of the village and the tent where she will meet the bridegroom, and beats the tent with a bamboo cane; but she does not smear the tent-pole with butter, nor does her mother-in-law take her to the four corners of the tent, as her baraka has remained with her first husband. She wears her slippers with pulled-up backs and sleeps in them at night. She has no belt round her waist till the sixth day after her arrival, but then she girdles herself without ceremony; and she makes no palmetto rope on that day, as does a virgin bride. If the bridegroom is a bachelor the ceremonies which 
have direct reference to him are observed just as if she were a virgin; and, on the other hand, if the bride is a virgin it makes no difference, so far as she is concerned, whether the bridegroom be a bachelor or an $d^{d d j} j a l$ (the Arabic $h d j j a l l$, or $h d^{d d} j a l$ ). In the latter case there is no ass ufran, nor is he painted with henna, nor does he pull up the backs of his slippers.

Among the Ait Yúsi a bride who has been married before smears herself with henna on her hands, feet, hair, and face, but no "moon" is painted with saffron over her head. When she leaves her home her brother does not spread his âban in front of her, and she does not ride, but goes on foot to the bridegroom's place. She wears her belt as any ordinary woman, but she has the backs of her slippers pulled up. She is not sprinkled with milk on the way, nor does she walk round the bridegroom's village before she enters it. If there is a mosque in the village, however, she walks three times round it, but not in company with any virgin bride. No tray with raisins is offered her by her mother-inlaw, and she neither beats the bridegroom's tent with a cane nor smears butter on the pole supporting its roof.

Among the Ait Nder, if the bride has had a husband before, she smears her hands, feet, and hair with henna, as women often do, but there is no ceremony connected with it. She walks to the bridegroom's place with the backs of her slippers pulled up, but already the next day she wears them in the usual manner. She does not make the seven circuits round the bridegroom's tent, 
and no figs are thrown over her. If she is still young, she spends the first seven days inside the enclosure in the tent where she meets the bridegroom; otherwise it is removed in the morning, to be put up again for the nights only. She wears her belt as usual, and if she is the only woman in the tent, she begins to work on the day after her arrival. If the husband has not been married before, he and his bachelor friends make the ordinary wedding tours to neighbouring villages, just as he has performed all other ceremonies incumbent on a bridegroom; but the case is different if this is not his first marriage, whether the bride be a virgin or a widow or divorced wife. Then no henna is smeared on his hands and feet; he neither covers his face nor pulls up the backs of his slippers, nor carries a sword; he is not regarded as a sultan and has no vizier, and there is no assembly of islan round him.

Nor are among the Ruâfa of the Ait Wäryâgäl a bridegroom who is not a bachelor and a bride who has been married before subject to the ceremonies mentioned in previous chapters. They make no tours before the wedding, and are not painted with henna in the manner described above. But the bride smears henna on herself a couple of days before she goes to her new home, whither she goes on foot; and on this day the bridegroom slaughters a sheep or goat.

From these facts it appears that the ceremonies of a purificatory or protective kind to which the bride or bridegroom is subject depend on the circumstance whether she or he, but not both parties, have been 
married before. A bridegroom who is a bachelor is subject to the same ceremonies whether the bride be a virgin, a widow, or a divorced wife, whereas these ceremonies are omitted in the case of a bridegroom who has or has had another wife, quite independently of the state of the bride; and a bride who has not been married before is subject to the same ceremonies whether the bridegroom be a bachelor, a widower, or a polygamist, whereas these ceremonies are, if not altogether done away with, at all events much reduced, in the case of a bride who is a widow or a divorced wife, quite independently of the state of the bridegroom. From all this I conclude that, even though some of the purificatory and protective marriage ceremonies have sprung from fear of hymeneal blood or from the idea that the bride may carry evil with her both as a newcomer into the bridegroom's household and in her capacity of being a woman, the bulk of these ceremonies are due to the fact that the person who is subject to them is bride or bridegroom for the first time. She or he enters into a new state, the wedding is a rite de passage; and to pass into a new condition or to do a thing for the first time is not only in this, but in many other cases, considered to be attended with danger. But it must in addition be noticed that in the present instance the nature of the act itself is apt to increase the supposed peril. Sexual intercourse is looked upon as defiling and under certain circumstances as a mysterious cause of evil. As evidence of this many facts may be adduced.

No sexual act must be committed in a holy place, a 
mosque or a shrine, nor is a person who has been polluted by any discharge of sexual matter allowed to enter such a place before he has washed himself. Should he do so he would suffer some misfortune; he would get blind, or lame, or mad, or he or some member of his family would become ill or die, or he would lose some of his animals, or his corn-crop would be bad. I was told that if a person who is not sexually clean visits the tomb of the Aglu saint Sîdi Daud, which is situated on an island, he will find that the water in the sea has suddenly risen to such a height that he cannot go back to the mainland, but has to wait till it has gone down. Nor is a person who is sexually unclean allowed to pray; once when I was staying in Háha and the water supply had become extremely scarce, my Berber teacher, who had always before most regularly said his daily prayers, refrained from doing so for a couple of days because his clothes had been defiled by a pollution. Owing to its injurious effect upon holiness, an act generally looked upon as sacred would, if performed by an unclean individual, lack that magic efficacy which is otherwise ascribed to it. The Moors say that a scribe is afraid of evil spirits only when he is sexually unclean, because then his reciting of passages of the Koran-the most powerful weapon against such spirits-would be of no avail. Sexual cleanness is required of those who have anything to do with the corn; for such persons are otherwise supposed to pollute its holiness, and also, in many cases, to do injury to themselves. In most parts of Morocco it is considered necessary for the 
ploughman to be sexually clean; otherwise there will be no baraka in the seed, or there will grow mostly grass and weeds on the field. ${ }^{1}$ So also the reapers ${ }^{2}$ and anybody who comes to the threshing-floor ${ }^{3}$ when the corn is there must be clean; and the same is the case with the women who clear the crops of weeds in the spring, lest their work should be without result and they should become ill themselves. ${ }^{4}$ If an unclean person goes into a granary, it is believed not only that the grain will lose its baraka, but that he himself will fall ill ; a Berber from the Ait Warain told me that he once got bad boils because he entered a granary in a state of sexual uncleanness. ${ }^{5}$ Nor must an unclean individual enter the vegetable garden, as such a visit would do harm both to the garden and to the person who went there (Ulâd Bu-'Ǎzîz, Andjra, Ait Warain). ${ }^{6}$ When a woman is grinding corn she must be clean, lest the flour should be bad (Andjra). ${ }^{7}$ Among the Ait Wäryâgäl a menstruating woman is allowed to milk the cows, sheep, and goats, but not a woman who has refrained from washing after she has had connection with her husband. In the same tribe it is held that if an unclean person goes among the sheep they will die, because they are holy animals and in consequence easily hurt by defilement. The Ulầd Bu-Ăzîz, again, maintain that under similar circumstances the person himself will suffer some misfortune; and in the Hiáina

1 Westermarck, Ceremonies and Beliefs connected with Agriculture, etc., in Morocco, p. 17.
2 Ibid. p. 23.
s Ibid. p. 46.
3 Ibid. p. 28.
4 Ibid. p. 22.
6 Ibid. p. 54 .
7 Ibid. p. 47. 
an unclean individual who comes to the place where the sheep are sheared is supposed to get diseased on account of their baraka. It is a universal belief in Morocco that if a person who is sexually unclean rides a horseanother holy animal-some evil will happen either to the horse or the rider, or both : the horse will get sores on its back or fall down with its rider, and the latter will have boils, or become ill or die, or be late in arriving at his destination or not succeed in his business. So also the person who robs the bees of their honey must be clean, lest they should leave the place or die, or the person himself be stung by them. Sexual intercourse, moreover, destroys the magical efficacy of a charm if it is not removed before the act, and I have also heard that in such a case the person who wears it may become ill. The Ait Sádden believe that the wound of a circumcised boy gets inflamed if an unclean person looks at it; and among the Ulâd Bu-Ǎzîz such a person must keep out of sight of any one who has been bitten by a mad dog, so as not to cause the rabies to break out. Blood-letting should be followed by three days' continence (Tangier, etc.) ; and it would be bad to have sexual intercourse the night before starting on a journey ( $\mathrm{Fez})$. He who is not clean sleeps badly, being haunted by $j n \bar{u} n$ or abandoned by his guardian angels.

That a polluting effect is ascribed to the discharge of sexual matter seems, largely at least, to be due to its mysterious propensities and the veil of mystery which surrounds the whole sexual nature of man. But the idea that sexual intercourse is defiling is also, no 
doubt, connected with the notions held about the female sex.

Islam does not look upon women with friendly eyes. It pronounces their general depravity to be much greater than that of men. ${ }^{1}$ According to Muhammedan tradition the Prophet said:- "I have not left any calamity more hurtful to man than woman. ... O assembly of women, give alms, although it be of your gold and silver ornaments; for verily ye are mostly of Hell on the Day of Resurrection." 2 The Moors say that women are defective in understanding and religion

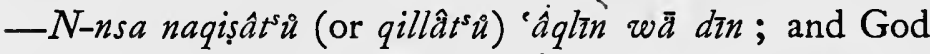
has excluded them from his mercy- $N$-nsa nsâhum llah mẹn rahamtu. They are friends of the devil; indeed, an old woman is worse than the devil-L-aghiza ăktsar mẹn Y̌-Yîtan. They are possessed with jnün, who help them to practice witchcraft, nay, many women are really jnün in human disguise. When Shĕm Hârush, the sultan of the jnunn, died, he left behind him a daughter who is still alive and assists her own sex in doing evil; hence women are even better versed in magic than scribes. Their looks are dangerous. At feasts they are allowed to eat first, since otherwise they might injure the men with their evil eyes. Once when I was sitting at my writing-desk, one of my servants rushed into my room and quickly closed the window-shutters; and when I, somewhat surprised, asked him why he thus shut out

1 Lane, Arabian Society in the Middle Ages (London, 1883), p. 219; Doughty, Travels in Arabia Deserta, i. (Cambridge, 1888), p. 238 sq.

2 Lane-Poole, The Speeches and Table-Talk of the Prophet Mohammad (London, 1882), pp. 161,163 . 
the light from me, he answered that some women had come to fetch water from the garden outside my cottage, and that he could not allow me to be exposed to their glances while I was writing. The curses of women are greatly feared; it is considered an even greater calamity to be cursed by a shereefa, or female descendant of the Prophet, than to be cursed by a shereef. Closely connected with these beliefs is the custom according to which a woman may serve as an asylum. Especially among the Berbers and Jbâla a man who takes refuge with a woman by touching her or sucking her breast or sitting down in front of her or going behind her or running into her house and taking hold of the handmill, is for the moment safe from his persecutor and must afterwards be protected by her husband or family. ${ }^{1} \mathrm{He}$ is in the woman's 'ar, and the protection given by women is particularly strong owing to the belief in their magic power and the great efficacy of their curses. ${ }^{2}$ The Shlöh say, Tamgart zud agurram, "A woman is like a saint." In times of fighting or uproar the women are left in peace; for a woman is horma or, in Shelba, lhorôm-she must not be touched. But, owing to their uncleanness, women are also subject to many taboos. They are not allowed to enter on the threshing-floor when the corn is there, lest

1 The same custom is also found in some of the Arab tribes of the plains, e.g., the Beni Aḅsen and Hiáina, but in most of these tribes, I think, it is dying out, probably owing to their subjection under the Sultan's government. Among certain Asiatic Bedouins, the tribe of Shammar, "a woman can protect any number of persons, or even of tents" (Layard, Discoveries in the Ruins of Nineveh and Babylon [London, 1853], p. 318).

2 Westermarck, ' $L$-'ar, or the Transference of Conditional Curses in Morocco,' in Anthropological Essays presented to E. B. Tylor, p. 366 sq. 
they should spoil its baraka. ${ }^{1}$ They are commonly, though not everywhere, ${ }^{2}$ forbidden to go into the granaries. In Andjra it is said that if an unmarried woman goes into a mătmür, or subterranean granary, she will never marry, that a married woman who does so will never have a child, and that a woman with child will have a miscarriage. ${ }^{3}$ Among the Ait Warain women do not work in the vegetable garden (tábhert), nor do they gather vegetables from it; among the Ait Yúsi, I was told, a woman can go there only by force, if she is more powerful than her husband $;{ }^{4}$ and the Ait Wäryâgal believe that a woman's presence in the vegetable garden (duabhert) would make it dry. Women are also supposed to be injurious to the bees; according to the Ait Warain the bees would die if a woman approached their nests, and everywhere the robbing is done by men. In the Hiaina no woman, except the farmer's wife and anybody she takes with her to help her in her work, must go among the sheep in the afternoon. Among the Ait Nder there are people who do not allow a woman to ride on their animals, not even on mules or donkeys, for fear lest the animal should suffer by it. In some places, at least, a woman is prohibited from entering a shop, even though she be the wife of the shopkeeper; should she do so, the

1 Westermarck, Ceremonies and Beliefs connected with Agriculture, etc., in Morocco, p. 28.

2 The Igliwa make an exception for such women as are in the habit of praying, but they are not numerous. In the Hiáina women are allowed to enter the granary but not to tread on the threshing-floor.

3 Westermarck, Ceremonies and Beliefs connected with Agriculture, etc., in Morocco, p. 46.

4 Ibid. p. 54. 
baraka would go away from the shop and there would be no sale. There are shrines that must not be visited by women. Thus for example, Sîdi 'Abdrrăḩman lhănbûbi, Sîdi Búnwar, and Sîdi Lủâfi-all in Agludo not permit women to enter the domed buildings in which they are buried. Should a woman see the grave of the Glawi saint Sîdi 'Ali Musa, at Arg, who died a bachelor, she would get blind; hence if the door of the room where he is buried is open, any woman who passes it has to hide her face. From the feasts of mujahédin, or hero saints who have died in fighting the Christians, women are, often at least, excluded. I was told that once when a woman went to the feast of the mujahédin called r-Rwâdi, on the seashore between Cape Spartel and Azila, which is celebrated in August, the big pot which is there for the use of visitors fell over her with its contents scalding her to death.

There are certain occasions on which woman is regarded as more unclean than usual, namely, after sexual intercourse until she has washed herself, when she has her monthly courses, and for some time after childbirth. She is then prohibited from visiting mosques and shrines, praying, and fasting in the month of Ramadān; and for forty days after the birth of a child the husband should abstain from his wife, though this rule is by no means always observed. The defiling effect ascribed to menstruation and childbirth is no doubt due to the marvellous nature of these processes and, especially, to the appearance of blood; and it is probably this frequent temporary 
defilement of a specifically feminine character that has led to the notion of the permanent uncleanness of the female sex. Now it seems obvious that, even though any discharge of sexual matter is considered to pollute a man, the intimate contact with an unclean being like a woman must increase the defilement of sexual intercourse-nay, it may be that this notion itself is more or less caused by the uncleanness of woman, who is the normal centre of the sexual life, and therefore may be supposed to have influenced the conception of its various manifestations.

The dangers to which the bride and bridegroom are believed to be exposed may be other persons' magical tricks or evil looks, or the attacks of jnunn, or that impersonal mysterious cause of evil which is denoted by the term l-bas. They all have more or less the same origin. Thus the jnun or spirits haunting the young couple are no doubt only vague personifications of the supernatural dangers threatening them on account of the new state of life into which they are about to enter, and of the particular character of the act by which marriage is consummated. I think that Dr. Samter, in his recent book, Geburt, Hochzeit und Tod, has somewhat misinterpreted the nature of the spirits which so commonly are supposed to be active at weddings, by regarding them mostly, though not exclusively, as the souls of dead people, ${ }^{1}$ and that he and others have exaggerated the influence which the belief in spirits generally has exercised upon the marriage ceremonies

\footnotetext{
1 Samter, Geburt, Hochæeit und Tod (Leipzig \& Berlin, 1911), pp. 207, 211 sqq.
} 
when, e.g., the breaking of earthenware vessels, ${ }^{1}$ or the casting of corn or rice or salt on the people or on the bride, ${ }^{2}$ or the throwing of an old shoe, ${ }^{3}$ or the use of some red colouring matter assumed to be a substitute for human blood, ${ }^{4}$ is represented as an offering to the spirits. This is surely to underrate the importance attached to impersonal magical forces; at all events I can confidently say that such assumptions derive no support from the customs and beliefs of the Moors. The jnun , which form a special race of beings created before Adam, are generally supposed to be active on occasions or in places which give rise to superstitious fear, and in many cases they are personifications of some mysterious qualities in persons or lifeless objects. They haunt unclean substances like blood and human excrements, they live in places of strange appearance, they cause sudden and unusual diseases. ${ }^{5}$ Corn, which is looked upon as a seat of magical energy not exclusively, though chiefly, of a beneficial kind, is at the same time constantly in danger of being stolen by jnün; ${ }^{6}$ a holy man is likewise particularly liable to be troubled with these irksome beings, and so is often his tomb. What else could the jnin in all these cases be if not personifications of the mysterious qualities of the persons or things in question? I have been told

1 Samter, op. cit. p. 60 n. 4.

2 Ibid.pp. 172-174, 201.

3 Ibid. p. 201 sqq.

4 Ibid. p. 186 sqg.

5 Westermarck, "The Nature of the Arab Ginn illustrated by the Present Beliefs of the People of Morocco,' in Fournal of the Anthropological Institute, xxix. (1900), p. 253 sq.

${ }^{6}$ Idem, Ceremonies and Beliefs connected with Agriculture, etc., in Morocco, p. 32 sq. 
that there are so many dangers at weddings because the devil wants men and women to indulge in lustfulness, and is therefore displeased when they marry; but this explanation cannot be primitive.

I have previously emphasised that similar ceremonies may be practised from different motives in different cases, and that also the same ceremony in a given case may have a mixed origin. This is obviously true of many of the marriage ceremonies which I have classed as prophylactic or purificatory. I certainly do not maintain that they in every case or exclusively are, or have been, intended to avert or expel supposed dangers or even to serve any definite object at all. Ceremonies which once had a purpose may, in the course of time, become entirely meaningless, and yet continue to be practised; and ceremonies may also be direct expressions of emotional states, whether combined with a special purpose or not. Just as funeral rites and mourning observances, even when they are intended to protect the survivors against the dead man's ghost or the contagion of death, are very largely similar to or identical with natural expressions of sorrow or grief, ${ }^{1}$ so the precautions taken at a wedding readily assume the shape of joyful performances, such as dancing, music, singing, the quivering noise of women, and the powder-play of men, which well agree with the mood of persons

1 See Westermarck, The Origin and Development of the Moral Ideas, ii. (London, 1908), pp. 308, 528 . 
attending a wedding-feast. Again, the extremely reserved behaviour of the bride and bridegroom, many of the abstinences which they have to observe, the covering up of their faces, the shutting up of the bride in a box, and the carrying of her out of her old home or into the bridegroom's dwelling, are not only means of averting supernatural dangers but also express or symbolise sexual bashfulness-a feeling which may easily be combined with superstitious fear; whilst in the wedding fights we clearly notice the antagonism which exists between different groups of people. A marriage is, as M. van Gennep puts it, "une perturbation sociale." 1 It deprives the bride's family of one of its members, hence her relatives show themselves unwilling to give her up. Her brother does not allow the bridegroom's people to take her away until they have paid him some money ; ${ }^{2}$ or he refuses to proceed to the door of the bridegroom's house unless "the things agreed upon" are given as a compensation for his sister ${ }^{3}$ or, if the bride has to cross a river on her way to her new home, her family claim money from the bridegroom's relatives because they are taking her so far away. ${ }^{4}$ But the feelings of the bride's people also express themselves in ceremonies of a more violent character. When the bridegroom's party come to fetch the bride, stones are thrown at them $;^{5}$ the bridegroom and two other men dressed like him are in one case beaten

1 Van Gennep, Les Rites de passage (Paris, 1909), p. 198 ; cf. ibid. p. 169.

2 Supra, pp. 80, 8x, 169, 186.

3 Supra, pp. 213, 214, 223.

4 Supra, p. 185 sq.

5 Supra, pp. 180, 186. 
by the men and women of the bride's village $;^{1}$ and her brother or uncle, before he carries her into the nuptial chamber, has a sham-fight with the bridegroom. ${ }^{2}$ Sometimes the latter is attacked by all the women assembled outside his house, ${ }^{3}$ or they curse both his and the bride's father, ${ }^{4}$ as if the marriage were an offence against their sex; and sex antagonism is also conspicuous in the fights between the bachelors and the unmarried women ${ }^{5}$ or the women in general, ${ }^{6}$ in the young men's attempts to take something from the bride, who is defended by the other women and the imsnein, and in the robberies which the men of the bridal procession commit on the bridegroom's mother and sisters as well as on the bride. ${ }^{8}$ The bridegroom is all the time surrounded by the bachelors of the village, who protect him against the married men's attempts to catch him or rob him of some of his belongings; ${ }^{9}$ whilst the bride is surrounded by the unmarried girls, who must never leave her alone, lest the married women should interfere with her property. ${ }^{10}$ But sometimes the bachelors also beat the bridegroom, who is defended by his best-man, and although this is said to rid him of evil influences it may at the same time be a ceremonial punishment inflicted on him by his bachelor friends because he is deserting their class. ${ }^{11}$

\footnotetext{
I Supra, pp. 198, 199, 223.

2 Supra, pp. $210,211,223$.

3 Supra, pp. $211,223$.

4 Supra, pp. 197, 223.

b Supra, pp. 237, 238, 269.

7 Supra, pp. 204, 223.

6 Supra, pp. 245, 247, 26 I, 268.

9 Supra, pp. 126, 128, 131, 233, 234, 269, 285 sq.

10 Supra, p. 144.

11 Supra, pp. 104, 107-1 10, 20.
} 
Side by side with prophylactic and cathartic ceremonies there are others which are supposed to confer more positive benefits on bride or bridegroom or both. To this class belong blessings and good wishes $;{ }^{1}$ the use of white things-eggs, ${ }^{2}$ milk, ${ }^{3}$ white clothes, ${ }^{4}$ silver coins, ${ }^{5}$ and other objects of silver, ${ }^{6}$ which are in many cases expressly said to make their lives bright and happy or to bring good luck or prosperity; and the giving of $\dot{g} r a ̂ m a,{ }^{7}$ which also seems to have a magical significance. ${ }^{8}$ Dates are eaten in order to make the couple wealthy, ${ }^{9}$ and the young husband buys fish to become prosperous. ${ }^{10}$ Various ceremonies are practised with the idea of increasing the live-stock, ${ }^{11}$ or of making butter or "grease," 12 or corn, ${ }^{13}$ or bread, ${ }^{14}$ abundant in the household, or, generally, of making the year good. For the lastmentioned purpose attempts are made to ensure an adequate supply of rain, by throwing the grit removed from the wheat which is to be used at the wedding into a spring, river, or water-course, ${ }^{15}$ or by sprinkling

1 Supra, pp. 95-98, 104, 125, 128, 129, 138, 155, 159, 194, 195, 199, 200, 202, 227, $231-233,244,248,250,258,269,275,280,292$.

2 Supra, pp. 89, 90, 97, 101, I1 3, I I 5, 124, I31, 145, 164, 194, 195, 260, 293.

3 Supra, pp. 25, 27, 28, 139, 145, 164, 170, 172-174, 180, 182, 183, 185, 190, 194, 226, 302-304, 308 ; cf. supra, p. 326 nn. 5 and 11 .

4 Supra, pp. 99, 106, 11 i, 124, 128.

5 Supra, pp. 33, 107, 146, 150, 152, 153, 157, 164, 174, 191, 207, 250, 258, 262 n. 2, 280-283, 287 sq.; cf. supra, pp. 322 n. 19, 325 n. 6 sqq.

6 Supra, pp. 72, 73, 91, 100, 103, 106, 107, 112, 124, 154, 164, 250, 286.

7 Supra, pp. 25, 28, 100, 103-105, 107, 109, 111-113, 116, 124, 125, 132, 138, $139,142,146,148,149,155,164,226,234,254,269$.

8 Supra, p. 125.

9 Supra, pp. 25, 27, 28, 139, 164.

10 Supra, p. 299 ; cf. supra, p. 293 n. I.

II Supra, pp. 196, 201, 204, 219, $221,222,232,298$.

12 Supra, pp. 201, 205-207, 221.

It Supra, pp. 195, 216, 217, 292, 296, 299.

13 Supra, pp. 201, 219.

15 Supra, pp. 90, 93 sq. 
the bride with water, ${ }^{1}$ or by offering her water which she sprinkles on the people round her $;^{2}$ and sometimes she is said to cast corn on the people, ${ }^{3}$ or in the face of the mare she has ridden, ${ }^{4}$ in order to make the year good. When the young wife has been girdled, she goes and gathers some fresh palmetto leaves to make her days "nice and green," and the year blessed. ${ }^{5}$ In one instance an egg is used "to give good luck to the bridegroom and a good year to the community;" "whereas in another instance the use of an egg is said to make the weather fine during the wedding, as well as to make the bridegroom's life bright. ${ }^{7}$ Other ceremonies are meant to promote cheapness, ${ }^{8}$ safety, quietness, or peace. ${ }^{9}$

There are further ceremonies which have reference to the relations between bridegroom and bride or husband and wife. Some of them are intended to facilitate the consummation of the marriage, ${ }^{10}$ though a sham attempt to prevent it, likewise by magic, seems sometimes to be made by women of the bride's family. ${ }^{11}$ Many ceremonies are practised with a view to making the wife fruitful, and, particularly, a mother of male offspring. When the bride has been dressed in her wedding-costume, the bridegroom's mother, and subsequently the other women also, sing :- "Go

1 Supra, pp. 180, 190, 203, 209, 216.

2 Supra, pp. 198, 216.

Supra, pp. 198, 217.

4 Supra, pp. 196, 219.

5 Supra, p. 298.

B Supra, pp. $113,124$.

7 Supra, p. 89.

8 Supra, pp. 201, 202, 221 sq.

9 Supra, pp. 201, 202, $221,222,232$.

10 Supra, pp. 151, 152, 164, 177, 179, 192, and, presumably, 232, 264 sq.

11 Supra, pp. 232, 264. 
out may you give birth to male twins, even one son I wish you to give birth to;" 1 or she carries a sieve, ${ }^{2}$ or a bundle of her son's old clothes, ${ }^{3}$ on her back, as if it were a baby; or the bride's mother is put into a net by the bachelors, and swung to and fro in the same manner as a child is rocked to sleep. ${ }^{4}$ The ceremony of the "tying of the hâyẹk" must be performed by a married woman who is blessed with children, so that the bride also shall become a mother. ${ }^{5}$ When the bride is taken to the bridegroom's place the animal on which she rides must sometimes be a mare, on account of its fruitfulness, ${ }^{6}$ and sometimes a stallion, that she shall give birth to male offspring. ${ }^{7}$ It is, in certain cases at least, for the same purpose that a little boy rides behind her on the mare $;^{8}$ and the custom which requires that the animal should also be ridden by a little boy when it is taken to the bride's place ${ }^{9}$ seems partly to serve a similar object. ${ }^{10}$ While the bridal procession goes round the mosque in the bridegroom's village, the bride asks Lälla Jẹbrîn to bless her with sons who will become scribes ; ${ }^{11}$ when she has been carried into his tent, his mother leads her to "the threshold of boys ;" 12 and a bachelor lifts up one of the tent-poles and puts it into her lap, in order that she shall remain in her new home and

\footnotetext{
1 Supra, p. 154 sq.

3 Supra, pp. 127, 128, 230.

2 Supra, pp. 195, 199.

5 Supra, p. 143.

- Supra, p. 246 sq.

6 Supra, pp. 175, 180, 191.

7 Supra, pp. 168, 191.

8 Supra, pp. 172, 174, 176, 179, 181, 185, 191.

9 Supra, pp. 172, 175, 191 sq.

$10 C f$., however, supra, p. $321 \mathrm{n} . \mathrm{r}$.

II Supra, p. 200.

12 Supra, pp. 201, 221 sq.
} 
support it by becoming a mother of sons. ${ }^{1}$ Just before the consummation of the marriage the bridegroom prays to God for offspring, ${ }^{2}$ or says two rek at followed by fâtha, which is considered essential for the production of good children $;^{3}$ and after the intercourse the more beautiful of the couple performs the usual ablution before the other, since it is believed that the children will resemble the parent who on this occasion washes first. ${ }^{4}$ Certain precautions are also taken to prevent the offspring getting diseased: some bridegrooms do not allow the semen to come into contact with the hymeneal blood $;^{5}$ others simply take care not to clean themselves with the same towel as is used by the bride $;^{6}$ and on the second day after she was fetched the bridegroom does not put on his girdle. ${ }^{7}$ When the week of the wedding has come to an end, there are again some ceremonies which are supposed to help the wife to become a mother of sons: the belting of her is performed by one or two little boys ${ }^{8}$ when she for the first time goes to fetch water, accompanied by other women, she fills with it her own and six other bottles in the hopes that by doing so she will give birth to seven sons ${ }^{9}$ or a boy whose parents are still alive gives her twice water to drink from his hands and, after filling them a third time, washes her face with the water. ${ }^{10}$

It may be that in the last-mentioned case not only

1 Supra, p. 202.

3 Supra, pp. 244, 255.

5 Supra, p. 265 sq.

7 Supra, p. 281.

9 Supra, p. 297.
2 Supra, pp. 232, 258.

4 Supra, pp. 159, 269 sq.

6 Supra, p. 266.

8 Supra, p. 292 sq.

10 Supra, p. 297. 
the boy but the water as such is supposed to promote fecundity in the newly-married wife. In the same tribe it is the custom for a married woman, who is anxious to know if she will be blessed with a child or not, to go to the sea-shore on l'ansart, or Midsummer, day, and the two following days as well, and let seven waves go over her body; then she knows that if she does not have a child soon, she will have none at all. ${ }^{1}$ That magic has here dwindled into divination is obvious from a similar custom practised in Andjra, where the young wife goes to the sea on the fortieth day after her arrival at her new home, and, while the seven waves are going over her body, says to the sea :- $A$ 'ámmi l-bhăar, ána meryáha, àtệni l-áulad u ș-sáhhạ, "O my uncle the Sea, I am troubled with spirits, give me children and health." Nor is it only in the case of women that water is supposed to influence fecundity : in Andjra animals are taken to the sea and bathed on Midsummer day in order to get fertile, and if a hen does not lay eggs, it is hung up in a tree while it is raining and a strong wind is blowing. It is well known that in various countries bathing ${ }^{2}$ and the drinking of water ${ }^{3}$ are practised as methods of obtaining children, and these practices have been traced to the ancient belief " that pregnancy was caused otherwise than by sexual intercourse." " But in Morocco, at least, the effect which water is held to have on the fecundity of women or female animals is only indirect, that is, it is

1 Westermarck, Ceremonies connected with Agriculture, etc., in Morocco, p. 86.

2 Hartiand, Primitive Paternity, i. (London, 1909), pp. 67, 75 sqq.

3 Ibid. i. 64 sqq.

4 Ibid. i. 154. 
supposed to remove the evil influences which cause sterility. This appears from the idea that the infertile woman or animal is meryáha, or troubled with evil spirits, and from the fact that the very same procedure as is adopted as a cure for barrenness, is also supposed to remove or prevent sickness or misfortune in general. ${ }^{1}$ Besides water, eggs are used for the purpose of promoting fecundity, in Morocco as elsewhere. ${ }^{2}$ Thus in Andjra a woman who is anxious to become a mother sits down over a new bowl in which she has put a raw egg and some $m a \underline{a} \underline{d}$-látisan, that is, rain-water which has fallen on 27 th April (Old Style)-the so-called nhar láisan-which is held to contain much baraka, and, therefore, is used for a variety of purposes $;^{3}$ but in order to be efficacious this water must neither have touched the ground nor been exposed to the sun. After she has been sitting over the bowl for a while, she drinks the water and puts the egg underneath a hen to be hatched; and it is believed that if the peeper is a cock she will give birth to a boy, and if it is a hen to a girl. In the same tribe a man who wants to increase his capacity of reproduction eats the yolk of an egg every morning before breakfast for forty days in succession, and after eating it fills the shell with oil, which he drinks. We have seen that eggs are prominent objects at Moorish marriage ceremonies, and the idea readily suggests itself that they are fertility

\footnotetext{
1 Westermarck, Ceremonies and Beliefs connected with Agriculture, etc., in Morocco, p. 85 sq.

2 Hartland, op. cit. i. 57 sqq.

3 Westermarck, Ceremonies and Beliefs connected with Agriculture, etc., in Morocco, p. 74 sqq.
} 
charms on these occasions also; but I have found no confirmation of this in the explanations given by the people. Nor have I heard that the fish which figure in ceremonies connected with marriages in Morocco are supposed to secure fertility, as is the case in some other countries ${ }^{1}$ but perhaps an idea of this kind was at the bottom of the custom of casting fish on the young wife's feet, spoken of by Leo Africanus as "a good boading." 2 It may be worth mentioning that among the At Ubáhti a fish is sometimes buried in a vegetable garden which does not thrive. The practice of receiving the bride with dried fruit, grain, or food made of corn, is not, to my knowledge, regarded by the Moors as a means of ensuring fertility; and that the bride's grinding of wheat over her bare thigh ${ }^{3}$ may be meant to serve such an object is only an inference on my part, to which I have been led by the use made of sieves in Moorish marriage ceremonies.

There are customs that have reference to the durability of the union, besides the one just mentioned, which is intended to secure male offspring as well. The bride is painted with henna by a married woman who has been married only once, as it is believed that if she had been divorced by a former husband, the same thing would also happen to the bride. ${ }^{4}$ The pelting of the bridal box with stones, when the bride leaves her parents' house, is sometimes represented as a safeguard against divorce. ${ }^{5}$ On her way to her new home she

I Hartland, op. cit. i. 48 sqq.

3 Supra, pp. 153, 162.

5 Supra, pp. 169, 170, 190; cf. supra, p. 179 sq.

2 Supra, p. 299.

4 Supra, pp. 141, 149, I50, 16 I. 
must not turn her head lest her husband should die. ${ }^{1}$ When she has arrived at the bridegroom's place, his mother washes her right foot and hand over one of the three fire-stones, in order that her daughter-in-law shall be as permanent in the house as these stones. ${ }^{2}$ The marriage tie is also strengthened by ceremonies referring to dress or food, which serve to seal the union or make it more intimate. The bridegroom sends his betrothed a new hâyẹk, and while she is dressed in it a married woman, who is her husband's first and only wife and much beloved by him, plaits its fringe; and this hâyẹk, as also other clothes which have been presented to the young man by his fiancée, are worn by him when he proceeds to his house to meet the bride. ${ }^{3}$ After they have had connection, the belt of the bride is, in one case, tied round the bridegroom's hâỵ̣̆k over the crown of his head ; ${ }^{4}$ and in another case the bride gives him two handkerchiefs, one of which he ties round his waist, and a cord, which she threads through his trousers. ${ }^{5}$ At the ceremony called $r$-rbet the bridegroom has on his feet a pair of slippers bought with money out of the bride's share of the dowry; ${ }^{\circ}$ and on the fortieth day after her arrival the young wife takes off her husband's slippers, puts them over her own, and slips a new pair on his feet, which is supposed to make the couple friendly to one another and prevent divorce. ${ }^{7}$ It is also undoubtedly with a view to establishing a

1 Supra, pp. 172, 189.

3 Supra, Pp. 127, 142, 143, 260 sq.

5 Supra, pp. 226, 227, 260.

7 Supra, p. 305.
2 Supra, p. 208.

4 Supra, pp. 249, 260.

6 Supra, pp. 102, 260. 
more intimate union between them that the bridegroom plaits the hair on one side of the bride's head. ${ }^{1}$ While the bride is still in her old home, a portion of food is sent from there to the bridegroom, as 'ahd between the parties. $^{2}$ Before they have intercourse they partake of food together, and the intimate character of this ceremony is increased by the bridegroom putting food into the bride's mouth, or by both of them pushing a little food into each other's mouths. ${ }^{3} \quad$ This common meal may be followed by another after the connection ; ${ }^{4}$ and in one instance there is a ceremonial meal the second night, when bride and bridegroom eat together the liver of the sheep slaughtered at " the great henna" and the egg which was in the bowl containing henna, the former for the express purpose of becoming dear to one another. ${ }^{5}$

There are other ceremonies performed by the bride or her friends with a view to making the husband fond of her or promoting domestic peace. ${ }^{6}$ But the aspirations of the bride may go further than this: she tries to make herself the ruler. For this purpose she mounts the ram which is to be slaughtered for the occasion when she is painted with henna and boxes its ears, the ram representing the husband $;{ }^{7}$ she hangs on it a necklace to make him weak and harmless like a woman; and when its stomach has been removed, she puts her right

I Supra, pp. 237, 247, 26i.

3 Supra, pp. 231, 237, 244, 250, $251,253,258$ sq.

4 Supra, pp. 244, 253.

2 Supra, pp. 144, 145, 259.

6 Supra, pp. 1 36, 143, 147, 1 58, 164, 170, 235, 236, $25^{8}$.

7 Supra, pp. 146, 157 sq. 
foot on it. ${ }^{1}$ The morning after the bride has been painted with henna, she is washed while seated on a weaving-stool and a pack-saddle, the riding of which is supposed to give her power over her husband. ${ }^{2}$ She tries to smack the bridegroom when he, together with two other men, is running through the tent, so as to become his mistress. ${ }^{3}$ She waves her right slipper seven times towards the door of the nuptial chamber when she hears his steps outside $;^{4}$ or she throws at him one of her slippers when he enters $;^{5}$ or she beats him three times on his body with her slipper when he is going to have connection with her, but in this case it is said that she will be the ruler of the house only if he cries out, whereas otherwise he will rule over her. ${ }^{6}$ The bridegroom on his part also tries in various ways to gain power over his wife. We are told that he for this purpose taps her three or seven times on her head or shoulder with his sword, ${ }^{7}$ or beats her three times between her shoulders with the cord of his dagger, ${ }^{8}$ or smacks $^{9}$ or kicks ${ }^{10}$ her gently, or drinks first from the bowl which he then holds for her to drink from $;^{11}$ and a similar idea is perhaps connected with his tapping her seven times between her shoulders with his right slipper, ${ }^{12}$ his attempt to strike her with a cane when she arrives at his house, ${ }^{13}$ her removing the slippers from his feet, ${ }^{14}$

1 Supra, p. $15^{8}$.

3 Supra, p. 198 sq.

5 Supra, PP. 244, 256.

7 Supra, pp. $235,244,256$.

9 Supra, Pp. 158, 159, 162, 256.

11 Supra, p. 232.

13 Supra, Pp. $214,217$.
2 Supra, p. 151.

4 Supra, pp. 235, 256.

6 Supra, pp. 252, 256 sq.

8 Supra, Pp. $250,256$.

10 Supra, pp. 242, 256.

12 Supra, pp. 248, 256; cf. supra, p. 251.

14 Supra, Pp. 237, 258. 
and her kissing his hand. ${ }^{1}$ In order to make her a "good wife," a brother or friend of the bridegroom gives her a silver coin when she has been lifted out of her parents' tent to be taken to her new home $;^{2}$ or the man who carries her into the bridegroom's house for the same purpose passes with her between his legs. ${ }^{3}$ Other ceremonies are supposed to make the bride "sweet" or dear to the bridegroom's family $;{ }^{4}$ or to put her on good terms with her mother-in-law $;^{5}$ or to make her fond of the cattle $;^{6}$ or to make the dog of the house friendly with her. ${ }^{7}$

It should be added that it is impossible in many cases to make a definite distinction between protective or purificatory ceremonies and such as are held to result in more positive benefits. The same substance or action may sometimes be looked upon as a means of averting or expelling evil, sometimes as a source of good, and sometimes as both at once. This is avowedly or in all probability the case with the milk or water which is sprinkled on the bride or offered her; the corn which is handed to her and then thrown by her over her head or on the people; the silver coins which are used in some way or other; the white clothes worn by the bridegroom or those who are near him; the beating, smacking, or tapping of the bride or bridegroom ; and the pelting of the bride with stones. The egg which the bridegroom's mother dips into milk and flour and throws at the forehead of the mule bearing

\footnotetext{
1 Supra, pp. 235, 258.

2 Supra, pp. 174, 191.

3 Supra, p. 21 r.

4 Supra, pp. 23, 147, 150, 164, 209, 217.

5 Supra, pp. 206, 222.

6 Supra, pp. 208, 222.

7 Supra, p. 296.
} 
the bridal box is said not only to prevent the bride from bringing evil with her but also to make her "white and red like the egg " and "a blessing to her husband." 1 The throwing of bread and dried fruit over the bride or bridal box is in one tribe regarded as a method of averting from her the evil eye, ${ }^{2}$ and in another tribe as a means of increasing the food-supply for the married couple $;^{3}$ and the dried fruit offered her or thrown over her is sometimes said to bring good luck, ${ }^{4}$ or to make everything sweet, ${ }^{5}$ or to make the bride sweet to the bridegroom's family. ${ }^{6}$ And when she gives the animal which she has ridden barley or sěkssu to eat and throws the rest in its face or over its head, she thereby removes injurious influences from it, ${ }^{7}$ or makes the corn plentiful in the household, ${ }^{8}$ or makes the year blessed and the animal fruitful. ${ }^{9}$ W.e have reason to believe that in the last-mentioned case and some other cases the prophylactic or purificatory motive is the original motive. But a rite performed for the purpose of averting or expelling evil may easily be regarded as a source of positive benefits, at least if it is a ceremony which contains baraka; and vice versa such a ceremony, when in the first place meant to bring benefits, may come to be looked upon as a rite of purification. Now baraka, or holiness, is a quality which plays an extremely important part in the ceremonies connected with a Moorish marriage. Many of the substances

1 Supra, p. 195. 2 Supra, pp. 213, 217.

4 Supra, pp. 204, 217.

6 Supra, pp. 209, 217.

8 Supra, pp. 201, 219.

3 Supra, pp. 195, 216 sq.

5 Supra, pp. 206, 207, 217.

7 Supra, pp. 205, 219.

9 Supra, pp. 196, 219. 
or objects used in them are saturated with it; certain ceremonies are performed by persons who have baraka in them, such as a shereef ${ }^{1}$ or shereefa, ${ }^{2}$ or a first-born boy with the holy name Muhammed, ${ }^{3}$ or a first-born girl bearing the name of the Prophet's daughter Fātima; ${ }^{4}$ and, above all, bride and bridegroom are themselves regarded as holy persons.

Though Islam considers marriage a civil contract, it nevertheless enjoins it as a religious duty "incumbent on all who possess the ability." 5 "When a servant of God marries, verily he perfects half his religion." ${ }^{6}$ It is related in the Traditions that the Prophet once asked a man if he was married, and being answered in the negative, said, "Art thou sound and healthy ?" When the man replied that he was, the Prophet said, "Then thou art one of the brothers of the devil." " The Moors maintain that a married man is blessed in this life and goes to Paradise after death, whereas a grownup man who dies a bachelor does not find the road to Paradise, but will rise again with the devil :-Ila māt' had 'ázri, inȟ̌šar mia Y-šitan. No wonder then that baraka, which is a blessing from God, is ascribed to bridegroom and bride, especially as there is something supernatural about them anyhow, on account of the

1 Supra, p. 24 ; shereefs and scribes as mediators at betrothals, supra, pp. 21, 22, 29-33, 35, 38, 42, 43, 45-47, 50, 52 .

2 Supra, p. 293 sq.

3 Supra, pp. II3, II9.

4 Supra, pp. 156, 161.

5 The Sayings of Muhammad, edited by Abdullah al-Māmun al-Suhrawardy (London, 1910), p. 55 .

${ }^{6}$ Quoted by Lane, Arabian Society in the Middle Ages, p. $22 \mathrm{x}$.

7 Mishkät, book xiii. ch. i., quoted by Hughes, $A$ Dictionary of Islam (London, I 896), p. 313 . 
new state of life into which they are about to enter and the mystery of its functions. There is no contradiction between their baraka and their dangerous condition or even the bass, or evil, seated in the bride. On the contrary, as has been noticed above, holy individuals or objects are very susceptible to all kinds of harmful influences, especially those of a supernatural kind. This I take to depend upon an association of ideas or, rather, a confusion of thought; the attribution of supernatural energy to the holy person or object has led to, or been confounded with, the idea that that person or object is in great danger of being hurt by other supernatural energy. And this idea is the more easy to understand as baraka itself implies not only beneficial energy but also a seed of evil or an element of danger. ${ }^{1}$

The baraka of the bride and bridegroom makes a wedding an occasion from which persons who take part in it, and even other people, expect to derive certain benefits. It is no doubt their baraka that is supposed to give efficacy to the ceremonies practised with a view to producing rain for the good of the crops. The henna which the bachelors smear on their hands and clothes is said to partake of the bridegroom's baraka. ${ }^{2}$ The dancing with the henna bowl and the passing of it from head to head may be supposed to have not only a

\footnotetext{
1 See Westermarck, Ceremonies and Beliefs connected with Agriculture, etc., in Morocco, p. 32 sq.; Idem, 'The Popular Ritual of the Great Feast in Morocco,' in Folk-Lore, xxii. (1911), pp. 132, 156 sqq.

2 Supra, p. 113.
} 
purificatory effect, but also to give those who dance with it the benefit of the baraka of the bridegroom or the bride. ${ }^{1}$ There is the holiness of "the Sultan" in the bullock which supplies the guests with meat, and particularly in its liver, a small piece of which is given to every man and boy $;^{2}$ and a little of his holiness is also transmitted to the spring into which he is pushed. ${ }^{3}$ When the bride leaves her old home she presents her brother or cousin, who spreads his cloak or hâyẹ̆k on the ground for her, with some silver money, which is supposed to give him good luck on account of her baraka. When milk is offered to the bride on her way to the bridegroom's place, she dips her finger into it or drinks a few drops and blows on the rest, so as to impart to it a little of her holiness, and the milk is then mixed with other milk to serve as a charm against witchcraft, or poured into the churn to make the butter plentiful $;^{5}$ or when, on her arrival at the bridegroom's place, his mother welcomes her with milk, she drinks of it herself and sprinkles some on the people. ${ }^{6}$ She hurls the lamb which is handed to her over the bridegroom's tent, so that there shall be many sheep in the village. The bread and dried fruit which is thrown over the bridal box and falls on the ground is picked up by people who want to benefit their corn by putting it underneath the heap on the threshing-floor ${ }^{8}$ or the bride throws the barley which is offered her on the

I Supra, p. I21.

s Supra, p. 126 sq.

5 Supra, pp. 170, 171, 183, 190; cf. supra, p. 210.

6 Supra, p. 207. 7 Supra, pp. 204, 221.
2 Supra, p. 125 sq.

4 Supra, pp. 175, 176, I91.

8 Supra, p. 195. 
people, who catch of it what they can and mix it with their own barley ${ }^{1}$ or she throws the $t^{s}$ rid given her over the people as a blessing $;^{2}$ or she throws the dried fruit which she has herself brought with her on the people, who by partaking of it are said to rid themselves of evil on account of the bride's baraka. ${ }^{3}$ After the couple have eaten together some tárfist, the bachelors must necessarily have a share of the same dish owing to the holiness with which it is saturated $;{ }^{4}$ and for a similar reason the tûrift brought from the bride's home is distributed among the people. ${ }^{5}$ When they come to look at the blood-stained garment of the bride, they rub their eyes with the stains, which are supposed to contain baraka and be wholesome for the eyes. ${ }^{6}$ When the young wife for the first time goes to visit her parents, taking with her bread and other food, she must give some bread to everybody whom she meets on the road $;^{7}$ and of the bread which she presents to her parents a portion is distributed among the people of their village. ${ }^{8}$ The domestic animals, again, are sprinkled by her with henna, so that they also shall profit by the baraka which still remains in the young wife. ${ }^{9}$

Among the benefits expected from a wedding we have still to notice some which are closely connected with the event it celebrates. Owing to a natural association of ideas, a wedding is looked upon as a potential cause of other weddings. Before the bride is

I Supra, p. $21 \mathrm{I}$.

4 Supra, p. 244 sq.

7 Supra, p. $309 ;$ if. 297.
2 Supra, p. 196.

5 Supra, p. 246.

8 Supra, pp. 302, 307 sqq.
3 Supra, p. 208.

6 Supra, p. 159.

9 Supra, p. 303. 
painted with henna, seven girls pour water over her at a spring and wash her body, hoping that by doing so they will get married themselves. ${ }^{1}$ The egg which is put into the henna bowl is subsequently eaten by one of the bride's girl-friends who wants to get a husband soon. $^{2}$ If any unmarried woman or girl is living in the house of the bride's parents, the bride is told to "drag her foot" when she leaves it, so as to help the unmarried one to a husband. ${ }^{3}$ When the bridal box is taken to the bride's village on the back of a mule, an unmarried youth sits inside it in order to get married soon ${ }^{4}$ or when the bride, on her arrival at the bridegroom's house, has been lifted down from the mare which carried her thither, a bachelor for the same purpose mounts the animal and has a ride on it. ${ }^{5}$ When the bridegroom returns from his visit to his parents-in-law, in the company of his mother-in-law, the unmarried women and little girls of the village go with them, so that they also shall marry. ${ }^{6}$ In this connection it is perhaps worth remembering that at a wedding the bachelors are gathered round the bridegroom, and the unmarried girls round the bride. I have not heard that this is thought to facilitate their own marriage, but I an inclined to believe that an idea of this kind is not far from their minds. The bachelors, together with the bridegroom, are often collectively called "bridegrooms," and the girls' relations to the bride bear resemblance to the married women's attitude

1 Supra, p. 153.
3 Supra, p. 165.
5 Supra, p. 196.

2 Supra, p. 145.

4 Supra, p. 168.

6 Supra, p. 291 sq. 
towards a child-bed woman; when a child is born, all the married women of the village assemble in the room or tent where the event takes place, partly to assist the mother by their blessings, and partly, as I was expressly told, to get a little of her baraka so as to become mothers themselves. At a wedding, also, the presence of friends and guests is held to benefit bride and bridegroom, both by the protection they give them against supernatural dangers, and by ceremonies which are supposed to make their lives bright and happy. It is, for example, considered obligatory on the women relatives of the bride to take part in the ceremony of $t^{s} a^{c} \hat{e} q$, when milk is drunk and dates are eaten, because their presence is thought to bring good luck to her $;^{1}$ and a similar idea underlies perhaps the prescription that an invitation to a wedding shall be accepted by everybody who receives it. ${ }^{2}$

The ceremonies connected with a Moorish marriage are thus partly individual and partly social in character. Among the ceremonies of a distinctly social kind should still be mentioned those which have a tendency to unite the families of the couple: the feasts and banquets in which members of both groups partake, the giving of presents, and the visits which precede and follow the wedding. Their social importance must be particularly great in a country like Morocco where a common meal is looked upon almost as an act of covenanting. If a Moor does harm to another with whom he has shared food, it is said that God and the

1 Supra, p. 139 ; ff. supra, pp. $25,28$.

2 Supra, p. 85. 
food will repay it-Rábbi $\hat{u} t$ t-țăâm ihgallụ̣s; the eaten food embodies, as it were, a conditional curse. ${ }^{1}$ But although there is a strong social element in the Moorish marriage ceremonies, although some of them might be classed among M. van Gennep's rites de séparation and others among his rites d'agrégation, it is beyond dispute that they in the first place have reference to the welfare of the two individuals who enter into the married state and therefore form the centre of the whole ritual.

I need hardly say that the explanations given in this book of marriage ceremonies in Morocco make no claim to be applicable to similar ceremonies in other countries. But, at the same time, I venture to believe that they may perhaps provide ethnologists with a few points of view which may be of general usefulness, and even make it worth their while to reconsider some of their old conclusions.

1 Cf. Westermarck, in Anthropological Essays presented to E. B. Tylor, p. 373 sq. ; Idem, The Origin and Development of the Moral Ideas, i. $5^{87}$. 



\section{ADDENDA}

WHEN the larger part of this book was already in type I became acquainted with the recent work Recherches anthropolngiques dans la Berbérie orientale-Tripolitaine, Tunisie, Algérie (Lyon, 1913), by Messrs. Bertholon and Chantre. An anthropological investigation of over 8000 natives has led the authors to distinguish three chief types of man in Eastern Barbary, namely: ( 1 ) short, dark-complexioned, longheaded people, members of the Mediterranean race; (2) short, dark-complexioned, brachycephalic people of less certain affinities ; and (3) tall, long-headed, rather fair people, probably descendants of a North European stock. Besides these three there is an important fourth type, the negro or negroid; and there are also minor types which the authors suspect to be due to intermixture of the chief types (see Dr. Keith's notice in Man, 1913, p. 165). As regards their silence about an Arab type they write (i. 347):- “Dans l'Afrique du Nord, il n'y a plus d'Arabes vrais qu'à l'état sporadique. Dans aucun groupement que nous avons examiné, nous n'avons rencontré de sujets au type arabe suffisamment nombreux pour imposer leurs caractères à la masse. La Berbérie est un pays arabisé moralement par l'importation d'un culte, qui se double d'une organisation spéciale théocratique; mais ce n'est pas une région, répétons-le, comportant des populations de race arabe proprement dite. Une forte erreur commise par les anthropologistes, à commencer par Broca, a consisté à décrire sous le nom d'arabes des tribus berbères plus complètement islamisées. que d'autres. Nous croyons avoir, dans cet ouvrage, tant dans la partie anthropométrique que dans la partie craniométrique, fait justice de cette erreur. Les tribus dites arabes du nord de l'Afrique présentent les mêmes caractères somatiques que d'autres tribus berbères sans conteste."

I desire to emphasise that, in applying the name "Arabs" to certain tribes in Morocco, I have not meant to express any opinion as regards their racial affinities, but have simply made use of a term ( $\left(\right.$ - $\left.^{\circ} \mathrm{r} a b\right)$ by which the people themselves denote the Arabic-speaking inhabitants of the plains; and by "Berbers" I mean Berberspeaking people.

P. 10.-Messrs. Bertholon and Chantre have devoted some pages (op. cit. i. 5.75 586) to Tunisian and Algerian marriage ceremonies, and have there endeavoured to show that the differences in these ceremonies correspond with the racial differences of the people who practise them; but the evidence they have brought forward in favour of this assertion seems to me to be very scanty. There are no doubt many points of resemblance between North African and European marriage ceremonies - this I have myself shown in the present book; and the new strength which Messrs. 
Bertholon's and Chantre's anthropometric and craniometric investigations have given to the theory of a racial affinity between Berbers and Europeans naturally increases our inclination to trace their customs to a common root. But we must remember, on the one hand, that similar customs may grow up independently among peoples of the same race as well as among peoples of different races, and on the other hand, that various marriage customs which prevail or have prevailed both in Northern Africa and Europe have also been found among Semitic peoples. Messrs. Bertholon and Chantre have certainly not given the Semitic influence its due share of attention. They write, for example (i. ${ }^{8}{ }_{5}$ ):- "L'exposition de la chemise de la mariée a encore lieu dans toute la péninsule des Balkans. Nous ne connaissons pas de documents sur ce sujet concernant l'ancienne Grèce. On peut croire que cependant ce rite a $\mathrm{pu}$, à une période antique, être répandu parmi les populations de la presqu'île hellénique." Not a word is said of the prevalence of the same custom among Semites, past and present (see supra, p. 268 n. 1, and, in addition, Burton's translation of The Book of the Thousand Nights and a Night, i. [London, 1894], p. 373 n. 3, as also Deuteronomy, xxii. I 5 sq9.).

P. 17 n. 2. -See also Hanoteau and Letourneux, $\mathrm{La}$ Kabylie et les coutumes kabyles, ii. (Paris, 1873), pp. 213, 214, 216 sq.; Bertholon and Chantre, op. cit. i. 576 (Tunis).

P. 25.-Among the Algerian Kabyles the fiancé, on the day of his betrothal, entertains the people of his village with figs and nuts, the figs being offered them "comme un présage de la douceur de la nouvelle union" (Hanoteau and Letourneux, op. cit. ii. $2 \times 3$ ).

P. 31 n.-At Tunis "le fiancé ne manque pas d'envoyer à sa future des petits cadeaux à l'occasion des fêtes" (Bertholon and Chantre, op. cit. i. 576).

P. 55 sq. n. 2.-At Tunis "le cousin germain, du côté paternel, a le droit de préemption sur sa cousine germaine du côté du père, même si elle est déjà fiancée. Il a même le droit de la prendre de force, si elle a été déjà mariée à un autre. Le père et la mère de la fille ne peuvent s'y opposer" (Bertholon and Chantre, op. cit. i. 575$)$.

P. 118 n. 1.-See also Hanoteau and Letourneux, op. cit. ii. 214 (Algerian Kabyles).

P. I 8 n. 3.-See also Bertholon and Chantre, op. cit. i. 578 (Tunis).

Pp. 120 n. 2, 16 n. 3.-See also Bertholon and Chantre, op. cit. i. 578 (Tunis).

Pp. 125, 162 sq.-Among the nomads of Eastern Barbary, when henna is applied to the hands and feet of the bride, "on colle avec du henné une pièce d'or dans chacune de ses mains, une pièce d'argent sous chacun de ses pieds. C'est un présage de bonheur" (Bertholon and Chantre, op. cit. i. 584).

P. $160 \mathrm{n}$. I.-See also Bertholon and Chantre, op. cit. i. $57^{8}$ (Tunis), $5^{84}$ (nomads of Eastern Barbary).

P. 187.-Among the Algerian Kabyles the bride "est hissée sur la mule par un nègre, s'il en existe un dans le village" (Hanoteau and Letourneux, op. cit. ii. 217).

Pp. 191, 196.-Among the Algerian Kabyles it is the custom that, when the bride descends from the mule on which she has been taken to the bridegroom's place, "mais avant qu'elle ait touché le sol, un jeune garçon s'élance en selle à sa place. Dans les préjugés kabyles, cette pratique assure à la femme un mâle pour premier-né" (Hanoteau and Letourneux, op. cit. ii. 218 ).

P. 215 n. 2.-Among the Algerian Kabyles, when the bride has arrived at the 
bridegroom's place, “ on lui apporte un vase rempli d'eau, dont elle répand le contenu à droite et à gauche sur les assistants" (Hanoteau and Letourneux, op. cit. ii. 218). At Tunis, on the same occasion, "une femme lave parfois les pieds de la fiancée. C'est un rite de purification au moment où elle pénètre dans un nouveau foyer" (Bertholon and Chantre, op. cit. i. 579).

P. $220 \mathrm{n}$. I.-Dr. Frazer thinks that the superstitions which have gathered round the threshold may be explained by the idea that it is an abode of spirits, and then asks why spirits should be supposed to have their seat at the threshold. "One possible answer," he says, "is suggested by a Russian custom. The peasants bury still-born children under the threshold; hence the souls of the dead babes may be thought to haunt the spot. But again we may ask, Why should the bodies of still-born infants be buried under the threshold? An answer comes from northern India. 'When a child dies it is usually buried under the house threshold, in the belief that as the parents tread daily over its grave its soul will be reborn into the family.' A similar belief probably explains the custom, common in Central Africa, of burying the afterbirth at the doorway or actually under the threshold of the hut ; for the afterbirth is supposed by many peoples, for example the Baganda, to be a personal being, the twin brother or sister of the infant whom it follows at a short interval into the world. By burying the child or the afterbirth under the threshold, the mother apparently hopes that as she steps out of and into the house the spirit of the child or of its supposed twin will pass into her womb and be born again. On this hypothesis the widespread belief in the reincarnation of the dead would explain the sanctity of the threshold. But it is possible, and indeed probable, that other causes still unknown to us have contributed to shed a glamour of mystery over that part of the house" (Frazer, 'Folk-Lore in the Old Testament,' in Anthropological Essays presented to E. B. Tylor [Oxford, 1907], p. 172 sq.). Dr. Frazer has thus, some years before Dr. Samter published his book, given actual instances of burials made under the threshold; but these instances are so few and of so exceptional a character that, in my opinion, no general theory as regards the world-wide fear of the threshold can be based on them.

P. $221 \mathrm{n}$. 1.-On the silence and immobility of a Tunisian bride Messrs. Bertholon and Chantre (op. cit. i. 579) observe, "Ce silence et cette immobilité doivent être imposés par la crainte qu'a la nouvelle famille de voir cette étrangère apporter des maléfices par ses regards, ses gestes ou ses paroles."

P. 22 I sq. n. 2.-At Tunis the bride is on her arrival at the bridegroom's house presented with some yeast as an "emblem of prosperity" (Bertholon and Chantre, op. cit. i. 579).

P. 256.-Cf. Hanoteau and Letourneux, op. cit. ii. 219 :-“ "Resté seul avec sa femme, le mari, avant de la conduire à sa couche, la frappe légèrement trois fois sur les épaules, avec le dos d'un sabre ou d'un poignard, pour conjurer les effets du mauvais œil" (Kabyles).

P. 258 n. 3.-At Tunis "les deux époux doivent boire une mixture composée de tamarin et de sirop de violette : puis ils échangent leurs tasses" (Bertholon and Chantre, op. cit. i. 580).

P. 261.-At Tunis "les cheveux de la mariée ne doivent pas être tressés. La coiffeuse les divise en deux parties par une raie placée généralement sur le côté droit de la tête. Une portion flotte sur le devant de la poitrine" (Bertholon and Chantre, op. cit. i. 578). 
P. 263 n. 1.-At Tunis "la fiancée ne doit pas porter de ceinture jusqu'au mariage" (Bertholon and Chantre, op. cit. i. 578).

P. 263 sq. n. 3.-At Tunis "la jeune épouse doit, le lendemain, trouver sous son traversin une bourse, contenant une somme d'argent variable selon les ressources du mari" (Bertholon and Chantre, op. cit. i. 580). Among the nomads of Eastern Barbary "au moment où il fait passer la chemise hors de la tente, le mari doit poser son pied sur celui de sa femme. Il lui remet en même temps une somme d'argent (4 ou 5 douros)" (ibid. i. 584).

Pp. 266 n. 1, 267 n. 1, 268 n. 1.-Cf. Hanoteau and Letourneux, op. cit. ii. 219:- "Si la nouvelle épouse est vierge, les femmes attendent le moment où le mari sort de la chambre, et, fier de sa victoire, l'annonce en tirant un coup de feu. A ce signal répondent des cris de joie, et les femmes se précipitent dans la chambre pour constater de visu la réalité de son triomphe" (Kabyles). Cf. also Bertholon and Chantre, op. cit. i. 584 :- "L'exposition de la chemise est accueillie par des youyou et des coups de fusil" (nomads of Eastern Barbary); and ibid. i. 580:- "La chemise de la mariée est présentée aux parents et aux invités. Des youyou célèbrent l'événement" (Tunis). In the Arabian Nights (the 39th Night, Burton's translation, i. 373) we read that on the night of consummation the throat of a pigeonpoult was cut and the blood sprinkled on the bride's shift. With reference to this passage Burton remarks (ibid. i. 373 n. 3 ) that the ancient practice of inspecting the marriage-sheet is still religiously preserved in most parts of the East, and that in old-fashioned Moslem families the sheet is publicly exposed in the harem.

P. 283.-At Tunis harqos is applied to the bride after she has had her bath and before she is painted with henna (Bertholon and Chantre, op. cit. i. 578).

P. 284.- "Dans les villages du Sahel Tunisien, il est d'usage que pendant la semaine qui suit la noce, le marié, accompagné de ses amis, aille se poster sur la route. Il jette le foulard de sa femme sur les divers passants. Chacun est tenu de rapporter l'objet qui l'a touché. Il doit y ajouter une somme d'argent, si minime soit-elle" (Bertholon and Chantre, op. cit. i. $5^{81}$ ).

P. 295 n. 1.-On my last journey to Morocco, when Chap. VIII. was already in type, I was told in the Fahṣ that dried fruit, r $\dot{g} a i f$, an egg, and a silver coin are given to each of the two boys who girdle the bride in order to make them happy and the act they perform auspicious.

P. 299 n. 1.-At Tunis, "dans la maison du futur, on confectionne des gâteaux en pâte feuilletée représentant surtout des poissons ou des serpents enroulés" (Bertholon and Chantre, op. cit. i. $57^{8}$; cf. ibid. i. $5^{84}$ ).

P. $3^{1} 3$ n. 1.-See Westermarck, The Origin of Human Marriage (London, 1891, 1894, 1901), p. 319 sq9.; Idem, The Origin and Development of the Moral Ideas, ii. (London, 1908), p. 368 sqq. In the latter work I replied to various objections raised against my attempt to explain the prohibition of marriage between kindred and exogamy, but since its publication new attacks have been made on my theory. Thus Dr. Frazer has criticised it in his work Totemism and Exogamy, vol. iv. (London, 1910), p. 96 sqq. I shall here insert the reply to his criticism which I published in Folk-Lore, vol. xxii. (1911), p. 86 sqq., especially because Dr. Frazer has drawn my attention to a point with which $I$ ought to have dealt more fully in my previous books. I wrote as follows :-

"My own belief is that there is an innate aversion to sexual intercourse between persons living very closely together from early childhood, and that, as such persons 
are in most cases related by blood, this feeling naturally displays itself in custom and law as a horror of intercourse between near kin. Dr. Frazer admits that there seems to be some ground for believing in the existence of 'a natural aversion to, or at least a want of inclination for, sexual intercourse between persons who have been brought up closely together from early youth'; but he finds it difficult to understand how this could have been changed into an aversion to sexual intercourse with persons near of kin, and maintains that, till I explain this satisfactorily, the chain of reasoning by which I support my theory breaks down entirely at the crucial point. For my own part, I think that the transition which Dr. Frazer finds so difficult to understand is not only possible and natural but well-nigh proved by an exactly analogous case of equally world-wide occurrence and of still greater social importance, namely, the process which has led to the association of all kinds of social rights and duties with kinship. The maternal and paternal sentiments, which largely are at the bottom of parental duties and rights, cannot in their simplest forms be based on a knowledge of blood relationship, but respond to stimuli derived from other circumstances, notably the proximity of the helpless young, that is, the external relationship in which the offspring from the beginning stand to the parents. Nor is the so-called filial love in the first instance rooted in considcrations of kinship; it is essentially retributive, the agreeable feeling produced by benefits received making the individual look with pleasure and kindliness upon the giver. Here again the affection is ultimately due to close living together, and is further strengthened by it, as appears from the cooling effect of long separation of children from their parents. So also fraternal love and the duties and rights which have sprung from it depend in the first place on other circumstances than the idea of a common blood; and the same may be said of the tie which binds together relatives more remotely allied. Its social force is ultimately derived from near relatives' habit of living together. Men became gregarious by remaining in the circle where they were born; if, instead of keeping together with their kindred, they had preferred to isolate themselves or to unite with strangers, there would certainly be no blood-bond at all. The mutual attachment and the social rights and duties which resulted from this gregarious condition were associated with the relation in which the members of the group stood to one another, - the relation of kinship as expressed by a common name; and these associations might last even after the local tie was broken, being kept up by the common name. Even we ourselves are generally more disposed to count kin with distant relatives who have our'own surname than with relatives who have a different name; and still greater must be the influence which language in this respect exercises on the mind of a savage, to whom a person's name is part of his personality.

"Here we have an immense group of facts which, though ultimately depending upon close living together, have been interpreted in terms of kinship. Why, then, could not the same have been the case with the aversion to incest and the prohibitory rules resulting from it? They really present a most striking analogy to the instances just mentioned. They have been associated with kinship because near relatives normally live together. They have come to include relatives more remotely allied who do not live together, owing to an association of ideas, especially through the influence of a common name; clan exogamy has its counterpart, for instance, in the blood feud as a duty incumbent on the whole clan. But there are also cases in which marriages between unrelated persons who have been brought up 
together in the same family, or who belong to the same local group, are held blamable or are actually prohibited; and so there are, even in early society, social rights and duties which are associated not with a common descent but with close living together. Dr. Frazer asks, - If the root of the whole matter is a horror of marriage between persons who have always lived with each other, how comes it that at the present day that horror has been weakened into a mere general preference for marriage with persons whose attractions have not been blunted by long familiarity? . . Why should the marriage of a brother with a sister, or of a mother with a son, excite the deepest detestation, . . . while the origin of it all, the marriage between housemates, should excite at most a mild surprise too slight probably to suggest even a subject for a farce, and should be as legitimate in the eye of the law among all civilised nations as any other marriage?' For my own part, I believe that marriage between a man and his foster-daughter, or between a fosterbrother and a foster-sister, in case the social relations between them have been exactly similar to those of blood-relatives of corresponding degrees, would cause more than a mild surprise, and appear unnatural and objectionable. I do not deny that unions between the nearest blood-relatives inspire a horror of their own, but it seems quite natural that they should do so, considering that from earliest times the aversion to sexual intercourse between persons living closely together has been expressed in prohibitions against unions between kindred. Such unions have been stigmatised by custom, law, and religion, whilst much less notice has been taken of intercourse between unrelated persons who may occasionally have grown up in the same household. Nor can it be a matter of surprise that the prohibitory rules so commonly refer to marriages of kindred alone. Law only takes into account general and well-defined cases, and hence relationships of some kind or other between persons who are nearly always kindred are defined in terms of bloodrelationship. This is true not only of the prohibitions of incest, but of many duties and rights inside the family circle.

"Dr. Frazer raises another objection to my theory. He argues that, if exogamy resulted from a natural instinct, there would be no need to reinforce that instinct by legal pains and penalties; the law only forbids men to do what their instincts incline them to do, and hence we may always safely assume that crimes forbidden by law are crimes which many men have a natural propensity to commit. I must confess that this argument greatly surprises me. Of course, where there is no transgression there is no law. But Dr. Frazer cannot be ignorant of the variability of instincts and of the great variability of the sexual instinct; nor should he forget that there are circumstances in which a natural sentiment may be blunted and overcome. Would he maintain that there can be no deep natural aversion to bestiality because bestiality is forbidden by law, and that the exceptional severity with which parricide is treated by many law books proves that a large number of men have a natural propensity to kill their parents? The law expresses the feelings of the majority and punishes acts that shock them.

“Dr. Frazer accuses me of having extended Darwin's methods to subjects which only partially admit of such treatment, because my theory of the origin of exogamy attempts to explain the growth of a human institution 'too exclusively from physical and biological causes without taking into account the factors of intelligence, deliberation, and will.' This, Dr. Frazer adds, is 'not science but a bastard imitation of it.' What have I done to incur so severe an accusation? I have 
suggested that the instinctive aversion to sexual intercourse between persons who have been living very closely together from early youth may be the result of natural selection. I am inclined to think, -and so is Dr. Frazer also, - that consanguineous marriages are in some way or other detrimental to the species. This fact would lead to the development of a sentiment which would be powerful enough, as a rule, to prevent injurious unions, - a sentiment which would not, of course, show itself as an innate aversion to sexual connections with near relatives as such, but as an aversion on the part of individuals to union with others with whom they lived closely together from early childhood. These, as a matter of fact, would be bloodrelations, and the result would consequently be the survival of the fittest. All that I have done, then, is that I have appealed to natural selection to explain the origin of a primeval instinctive sentiment; and I can never believe that this is to transgress the legitimate boundaries of Darwinism.

"Dr. Frazer himself thinks that "we may safely conclude that infertility is an inevitable consequence of inbreeding continued through many generations in the same place and uncer the same conditions,' and in support of this view he quotes the valuable opinions of Mr. Walter Heape and Mr. F. H. A. Marshall. He thus finds that the principles of exogamy present 'a curious resemblance' to the principles of scientific breeding, but he rightly assumes that this analogy cannot be due to any exact knowledge or far-seeing care on the part of its savage founders. How then shall we explain this analogy? Dr. Frazer's answer is that 'it must be an accidental result of a superstition, an unconscious mimicry of science.' In prohibiting incest the poor savages 'blindly obeyed the impulse of the great evolutionary forces which in the physical world are constantly educing higher out of lower forms of existence and in the moral world civilisation out of savagery. If that is so, exogamy has been an instrument in the hands of that unknown power, the masked wizard of history, who by some mysterious process, some subtle alchemy, so often transmutes in the crucible of suffering the dross of folly and evil into the fine gold of wisdom and good.' I hope it will not be considered uncalled-for impertinence on my part to ask if this reasoning is a specimen of what Dr. Frazer regards as science proper in contradistinction to my own 'bastard imitation of it'?

"In any attempt to explain the origin of exogamy there are, in my opinion, three parallel groups of facts of general occurrence which necessarily must be taken into consideration:-Firstly, the prohibitions of incest and rules of exogamy themselves; secondly, the aversion to sexual intercourse between persons living together from early youth ; thirdly, the injurious consequences of inbreeding. As for the facts of the first group, Dr. Frazer and I agree that they all have the same root, exogamy being in some way or other derived from an aversion to the marriages of near kin. As for the facts of the second group, Dr. Frazer at all events admits that 'there seems to be some ground' for believing in them. As for the facts of the third group, there is complete agreement between us. I ask,-Is it reasonable to think that there is no causal connection between these three groups of facts? Is it right, as Dr. Frazer does, to ignore the second group altogether, and to look upon the coincidence of the first and the third as accidental? I gratefully acknowledge that Dr. Frazer's chapter on the Origin of Exogamy has strengthened my belief in my own theory; and, considering on the one hand the nature of his objections to it and on the other hand our agreement in many essential points, I cannot help cherishing the hope,-although I apologise for expressing it,-that the last 
differences of opinion will disappear some day when Dr. Frazer is reconsidering the whole question with that fair impartiality which is one of the finest qualities of his genius."

Other objections to my theory have been made by Messrs. Hose and $\mathbf{M}^{\prime}$ Dougall in their recent work on The Pagan Tribes of Borneo, vol. ii. (London, 1912), p. $197 \mathrm{n}$. They observe that intercourse between a youth and his sister-by-adoption is not regarded as incest in these tribes, and that they know at least one instance of marriage between two young Kenyahs brought up together as adopted brother and sister. "This occurrence of incest between couples brought up in the same household," they say, "is, of course, difficult to reconcile with Professor Westermarck's well-known theory of the ground of the almost universal feeling against incest, namely that it depends upon sexual aversion or indifference engendered by close proximity during childhood." They moreover maintain that "the occurrence of incest between brothers and sisters, and the strong feeling of the Sea Dayaks against incest between nephew and aunt (who often are members of distinct communities)," are facts which are fatal to this theory.

When I made my attempt to explain the rules against incest $I$ did not, of course, overlook the fact that these rules very frequently have reference to persons who are, or may be, members of different communities. I wrote (Human Marriage, p. $33^{\circ}$ sq.) :- " In a large number of cases, prohibitions of intermarriage are only indirectly in fluenced by the close living together. Aversion to the intermarriage of persons who live in intimate connection with each other has provoked prohibitions of the intermarriage of relations; and, as kinship is traced by means of a system of names, the name comes to be considered identical with relationship. . . . Generally speaking, the feeling that two persons are intimately connected in some way or other may, through an association of ideas, give rise to the notion that marriage or intercourse between them is incestuous." How could anybody deny the operation of the law of association, for instance, in the Roman Catholic prohibition of marriage between co-sponsors, or in the rule prevalent in Eastern Europe, according to which the groomsman at a wedding is forbidden to intermarry with the family of the bride, or in laws prohibiting marriage between relatives by alliance? Why, then, might not the same law have acted upon other relationships also, such as those constituted by a common descent or a common name? As for the influence of the name, I may mention the fact that the Chinese Penal Code punishes with sixty blows any one who marries a person with his own surname, although among the entire Chinese population of the Empire there are said to be only about $53^{\circ}$ different surnames. Messrs. Hose's and M'Dougall's own attempt to solve the problem is, if I understand them rightly, based on the supposition that the prohibitions of intermarriage originally referred to persons who belonged to the same community. They write:"If we accept some such view of the constitution of primitive society as has been suggested by Messrs. Atkinson and Lang (Primal Law), namely, that the social group consisted of a single patriarch and a group of wives and daughters, over all of whom he exercised unrestricted power or rights; we shall see that the first step towards the constitution of a higher form of society must have been the strict limitation of his rights over certain of the women, in order that younger males might be incorporated in the society and enjoy the undisputed possession of them. The patriarch, having accepted this limitation of his rights over his daughters for the sake of the greater security and strength of the band given by the inclusion of 
a certain number of young males, would enforce all the more strictly upon them his prohibition against any tampering with the females of the senior generation. Thus very strict prohibitions and severe penalties against the consorting of the patriarch with the younger generation of females, i.e. his daughters, and against intercourse between the young males admitted to membership of the group and the wives of the patriarch, would be the essential conditions of advance of social organisation. The enforcement of these penalties would engender a traditional sentiment against such unions, and these would be the unions primitively regarded as incestuous. The persistence of the tendency of the patriarch's jealousy to drive his sons out of the family group as they attained puberty would render the extension of this sentiment to brother-and-sister unions easy and almost inevitable. For the young male admitted to the group would be one who came with a price in his hand to offer in return for the bride he sought. Such a price could only be exacted by the patriarch on the condition that he maintained an absolute prohibition on sexual relations between his offspring so long as the young sons remained under his roof." I should like to know how Messrs. Hose and M'Dougall, on the basis of this theory, would explain "the strong feeling of the Sea Dayaks against incest between nephew and aunt (who often are members of distinct communities)," and, generally speaking, the rules prohibiting the intermarriage of persons belonging to different local groups. For the rest, I must confess that the assumptions on which their whole theory rests seem to me extremely arbitrary. Brothers are prohibited from marrying their sisters because the old patriarch drove away his grownup sons out of jealousy; but his jealousy was not strong enough to prevent other young males from joining the band. On the contrary, he allowed them to be incorporated in it, because they added to its strength; nay he gave them his own daughters in marriage, and refrained henceforth himself from intercourse with these young women so rigorously that ever since a father has been prohibited from marrying his daughter. But the young men had to pay a price for their wives. It may be asked : why did not the old patriarch accept a price from his own sons or let them work for him, instead of mercilessly turning them out of their old home, although they would have been just as good protectors of it as anybody else? And why did he give the young men his daughters? He might have kept the young women for himself and let the young men have the old ones. This is what is done by the old men in Australia, where the young girls are, as a rule, allotted to old men, and the boys, whenever they are allowed to marry, get old lubras as wives (Malinowski, The Family among the Australian Aborigines [London, 1913], p. 259 sqq.). Yet, in spite of this custom, there is no country where incest has been more strictly prohibited than in Australia.

Messrs. Hose and $M$ 'Dougall maintain that the occurrence of incest between brothers and sisters and the feeling of the Sea Dayaks against incest between nephew and aunt are facts which seem "to point strongly to the view that the sentiment has a purely conventional or customary source." I ask : is it reasonable to suppose that, if this were the case, the feeling against sexual intercourse between the nearest relatives could have so long survived the conditions from which it sprang without showing any signs of decay? The prohibited degrees are very differently defined in the customs or laws of different peoples - generally speaking, they are more numerous among peoples unaffected by modern civilisation than they are in more advanced communities; but $I$ think it can be shown that the extent to which 
relatives are prohibited from intermarrying is closely connected with the intimacy of their social relations. Whilst among ourselves cousins are allowed to intermarry, there is still a strong sentiment against intercourse between parents and children and between brothers and sisters, who in normal cases belong to the same family circle. Why should the feeling against incest have survived in this case but not in others, if it had a purely conventional origin? And how could any law based on convention alone account for the normal absence of erotic feelings in the relations between parents and children and brothers and sisters? Although law may forbid a son to marry his mother, a father to marry his daughter, and a brother to marry his sister, it could certainly not prevent his desiring such a union; has any law yet been able to suppress, say, adulterous inclinations ? Plato (Leges, viii. ${ }_{3} 8$ ) observed that an unwritten law defends as sufficiently as possible parents from incestuous intercourse with their children and brothers from intercourse with their sisters, and that "not even the thought of such a thing ever enters at all into the minds of most of them." It is true that cases of intercourse between the nearest relatives do occur, but they are certainly quite exceptional. Messrs. Hose and M'Dougall say themselves (p. 198) that "incest of any form is very infrequent" among the tribes of Borneo, and they seem to know of only one instance of marriage between young Kenyahs brought up together as adopted brother and sister, although such marriages are allowed. Considering the extreme variability to which the sexual impulse is subject, it is not astonishing that cases of what we consider incestuous intercourse sometimes occur; it seems to me more remarkable that the abhorrence of incest should be so general and the exceptions to the rule so few. To maintain that these cases are fatal to my theory seems to me as illogical as it would be to assume that the occurrence of a horror feminae in many men disproves the general prevalence of a feeling of love between the sexes. 


\section{INDEX OF ARABIC WORDS}

alîyẹn, I 3 I, I 33, I 40, 274 , 276,278

ámān, I 36

áulad, $35 \mathrm{I}$

awwâdin, I I 7

a'tîya, kémlet l-ạtîya, 23

bâba, bâha, bak, I00, I97 bágla, $4 \mathrm{I}$

baraka, 2I, 24, I I 3, I I 8,

I 20, I 2 I, I 26, I 27, I 43 ,

I 59, I 79, I 83, I 90, I $9 \mathrm{I}$,

I 95, I 96, 205, 208, 2 I I,

2 I 7,2 I 9 n., 245, 246,

26I, 265, 292, 302, 303,

308, 309, 331, 336, 337,

$340,341,352,358-362$, 364

bạs, 9I, 99, IOI, IO3, I 2 I,

I 7 I, I 95, I97, 2 I 7, 220

$n^{1}, 235,237,245,256$, $26 \mathrm{I}-264,267,294,298$, 304-306, 323, 342, 360 bătța (l-), I 57, I 73 bázin, 244

bdü (l-) u l-ăqid del-ḥâyệk del-carûșa, I 27,142 bégra, $4 \mathrm{I}$

bëndîr, plur. bnâder, I 43,

I 73, 294

bent, bents, plur. bnă $t^{s}, 54$, 90, 236, 318; bent ${ }^{s}$ lmkun, 236 ; bĕnt (bint), plur. bnäts' 'amm, 54, 55, $5^{6} n^{1}, 90$

bérrah, berrráh, bérrāh, 100, I05, I 32

bhar, plur. bhor, 236, 35 I biád l-ûjah, I 93

bilyün, 69, I I 6, I 46, 234 bint (bent) 'amm, 54, 55, $56 n .^{1}$

bismillạh, bismillàh, 98, 255 bit $t^{s} r$-ráha, I 40

bläd, mwâalin l-bläd, 296

bnâder. See bëndìr

$b n \ddot{a} t^{s}$. See bënt

brệwàt ${ }^{s}, 278$

bstêla, 278

büja, I $68 n .^{2}$

bưs, 297

bûYiyạr, bưsiyär, 237, 238, 297-299, 303; șbah buิYiyạr, 238 
dăhŶǔa, 134, I 35, 193, | düf. See daif

I 94, 226, 227, 275-277 dyaf. See daif

dar, I 3 I-1 33, I 38, I 93 ,

I 94, 225-228, 274-

$276,279,314$; dar

islän, I 3 I-133, I 93,

194, 225-228, 274-

276,329 ; dar l-örs,

I 3 I, I 32, I 93, 225,

$227,228,274-276,279$,

3 I 4,329

dbälj, 83

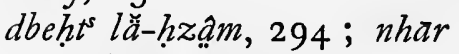
$d$-dbêha, 78, I 4 I

demm, 55

démlīj, IO3

dérra, plur. drer, 226

derbûga, I 43

dérham, 26I, 262, 296 ; dërham l-ftsöh, 262

dhäz, 82, 83, 238, 33 I

din, 338

$\operatorname{dn} \bar{u} b, 297$

dora (d-), I 38

drer. See dérra

dwáwặh, 83

dhol l-ḩáima, 302

dü l-jalâl, 97

díbya, 282

ḋärats, 277

daif, dïf, plur. dyaf, 21 , $29,32,40,296$

dfáyer, 277

dha, 234

drif, IO I

fakya, 228

farajîya, 225

fars, 1 34, 279 ; nhar l-fary,

I 34 ; tîoh l-fars, 279

fâsoh, 104

fâtha, fâtsha, I7, 22-25,

27,3 I, 33, 35, 38, 39,

$43,45,46,50,52,53$, $68,69,78$, I 29, I 86, I 99, 208, 209, 239, 244, 250, 282, 305, 326, 350 ; lîlěts fâtsha, 25

féndaq, 28

fqâqas, 142

fqer, 3 I I

$f q \pi, 29-31,38,46,50,52$, 68,77, I 27, I 29, I 30, I 44, I 69, 233, 234, 26I, 280

fqîra, I 4 I-I 43, 280

$f t^{s} \hat{a} t^{s}(l e-), 297$

ftöh (lle-), ftsoh (l-), 262 ; dérhạm l-ftsöh, 262

ftôr (l⿱艹ё-), 278 sq.; nhar lex-ftôr, 279

fûta, 234

gdṣa, 34, I 58, 236, 306 ;

l-gáșa dẹs-svah, 236

gellâsa, 227

gúbba, I 66

gúlla, 82

gaiyâda, 95, 145, 169, 234; l-grâma del-ǵaiyâdda, 234 
ġaiyâtin, 227

ǵamâtma, 129

ǵárbäl(plur. ǵrâbel), gd́rbäl, g்iobạl, 91, 195, 199, 233

$\dot{g} d a$, I 44

ǵdîya (lă-) del-ěrrûșa, I 44, 259

grâbel. See $\dot{g} a \dot{r} b \ddot{a} l$

ġrâma, I I I, I I 7, I 24, I 25, I $32, I_{40}, I_{42}, I_{4} 6, I_{4} 8$, I 55, I 64, 234, 269, 347; l-ǵrâma del-ǵaiyâda, 234; l-grama deș-súltan, 234 ; l-ğrâma fĩ l-múnbar, I 40; l-grâma 'al lă-'rîs $f$ ysullya, 132

grîiba, 24, 278, 30 I

$\dot{\xi} s i l$, I 26, 277, 279 ; l- $\dot{g} s i l$ del-hănna, I 26 ; nhar lạ$\dot{g} s \hat{\imath} l, 277,279$

$h a b d r, 236$

hạddàyı̆n, I69-17 I, I 94,

I95, 23I-235, 264, 267,

$279 \mathrm{sq}$.

hád da $^{2} l, 329,332$

hajjjâala, hädd jậla, I 59,329sq. hdîya, 30, 70, 77 sq. ; l-

hdîya den-nqa del-qauts,

77 ; l-h dîtya det-tsaur, 78 hnîya, 233

häbb r-rüs, 303

háiti, I 34

hájjam, I 32

hạjba, 198 hâjeb (l-) deș-șúlțan, 97, 230, 23 I, 234

hall r-ras, nhar hall r-ras, 276

hạllân l-hặzậm hadllän lähzâm, I 59, 237, 239

hámmạm (l-), 277 ; hámmạm n-nwâla, 306 ; l-

lîla del-hạmmạm, I4 I

hănna, 90, IOI, I26, I37 ;

l-hănna be t-tsqwîșa, I 37 ;

l-hănna l-kbîra, IOI ; lhánna s-ṣgêra, IOI; lġsil del-hănna, 126

hännáya, miállma l-hännáya, I 37

hâni, 103

hántoz, 277

hárrăqsus, I 76, 202

hárgos (hárqoș), 283

harm, I $28 \mathrm{sq}$.

hármel, 104,305

hárqoș, I 4 I $n .{ }^{2}$, 193, 283 ,

370

harțêta, 307

hatțâra, plur. htâtạt, 27 ,

28, I 39, I 40, 228, 229,

$275-277,279$

hâyẹk, 3 I, 70, 96, 102-104, I I I, I 23, I 26-I 28, I 42, I 43, I 56, I 66 n., I 75, I 9 I, I 98, 226, 23 I , 249, $260,265,273,349,354$, $36 \mathrm{I}$; l-bdu u u l-èqid delhâyẹ̌k del-`ărûșa, I 42 hặzọm, hặzậm, hẵâam, hrạm, 82, I 59, 22 5, 237, 
239, 293 sq.; lä-hzạm dyäl lă-êûsa, 293 ; dbehts lă-hzầm, 294 ; hăllân lhăgậm, hadllan iă-hzậm, I $59,237,239$; nhar lhăzạm, 293

hbib, plur. habab, 55

hju $b, 138$

hlàwa, 81, I 69

hmā, h̆ma, 197, 31 8

hmû, 3 I 8

hórma, 339

htâtar. See hattâra

hzạm. See hặzạm

ḩâdĕm, I 4 I

hadima, dhol l-háima, 302 hair, hair, 31, IO3 sq. hâläk, 55

hárja (l-), $30 \mathrm{I}$

háttab, plur. hatțâbin, I 9

hatțâba, plur. ḩattâbat, 20,

37

hătțaf lă-ráis, 160

hayyi, 90, 100, I03

hotba, 19

hrâreb, 67

$h t^{s} \bar{a} n$ (lát-), 3 I 2

$\tau d$, yidd, 98, 100, 103

islạn, yislän, y̆̌slän, ${ }^{1}$ IO2, 104, 105, 148, 236, 237 , 269, 28 I-283; där islän,

I 3 I-I 33, I 93, I 94, 225 $228,274-276,329$

iy $\bar{a} m, 98$

1 A Berber word used by Arabicspeaking people. izār, izār, I39, I40, I 52, I $95 \mathrm{sq}$.

djalâl, dü l-djalâl, 97

(a) jawi mekkdwi, 83, 244 (d) jẹlláb, djẹllạba, 99 n., I I 4, I 75

jẹnn, djinn, I 60, 232, 255

(d) jnun, IO3, IO5, I I 2, I I 9, I 22, I 23, I 36, I 47, I 50 , I 54, I 63, I 66, I 87,208 , $220,237,244,254,256$, 296, 306, 338, 342 sq. djwâri $\left.{ }^{d-}\right), 78,142,146$; nhar d-djwầri del-'ărûșa, $78,1_{4} 6$

kali', $66 n^{2}$

kamâlalal (l-), 97

$k a^{i} b \dot{g} z e l, 24,278,301$

kélba, 236

kémlet l-a'tîya, 23

kënbūs, 82

klàm (l-) l-maiqol, 3 I I

kmäl, nhär l-kmäl, 3 I, 70 kmām, 98

$k r \bar{a}, 79$

$k s \bar{a}, 96 n^{1}, \mathbf{1} 66,225$

kúsksu, 31, 89, 96, 99, I 25 ,

I 30, I 44, I 69, I 95, 280,

$28 \mathrm{I}, 302$

kutts $a b, 274$

$k \breve{u} t \hat{\imath} y \bar{a} t, 83$

ldaisan, 352 ; l-ma dé-látisan, 352 ; nhar láisan, 352 lalla, 3 I 7 
lhaf, I 33

libra, I 38

lîla (l-) del-hạmmmam, I $4 \mathrm{I}$; linla del-ärûs, I I 7 ; llîla l-kbîra, I42; l-lîla l-kbîra del-̌urûisa, I 46 ; l-lîla s-sgêera, I 4 I sq.; l-lîla s-śgêra del-earrûsa, I 44

lîlĕț (l-) del-‘ărûs, 95 ; lîlèts fâtsha, 25

limuin d-daqq, I 32

lulîya, 23 I

lùs, 3 I 8

lûsa, 3 I 8

lūz máqli, 277

$m \bar{a}$, I 36; l-mad d̆e-láisan, 352 mahr, 65, $74 n .^{2}$

mákla, 77

manșorîya, manșūîiya, I 52 $n^{2}, 236 \mathrm{sq}$.

märhôn, I 38, I 94 marhabâ, márh̆ăba, marhăbá, márhaba, 29, 30, $32,40,172$

măsța, 83

mä̌̌ál, plur. msâa al, I 39 sq. $m \ddot{a} t m \bar{u} r, 340$

mämla, nhār l-mámla, 3 I

mbârăk, 24

mdẹjja, I $5^{8}$

mdárrba, $3 \mathrm{I}$

meidûna, 103

mёjĥेl, I 38

mméllek, mméllka, 20

mélha (l-) l-háyya, I05 mméllka. See mméllek ménsi, n-nhār l-ménsi, $28 \mathrm{I}$ meryáha, 35 I sq. messûs, I 38 , I 94

mes'ồud, möscơ̂u $\underline{d}, 24,95$ sq.

mẹsmār, I 43

métqal, 66-68

mĕziạn, I 59

mézwud, 100, I02, 106,

I 52, I 76, 237, 269

mǵanniạt, 105

mhar, 66

mhákma (lè-) del-qâdi, 28

$m h a_{n}{ }^{2} a, 278$

miâdi, 24, 277, 278, 30 I

$m \hat{\imath} t^{s} a l, 83$

$m k e b$, I $32,228,278$

$m k u n$, bent l-mkūn, 236

mlạh, I 26

mläk (l-), 3 I

mra, lě-mmúdda dyält lmra, 239, 282

$m r \bar{a}, 3 \mathrm{I}$

mร̌âal. See mâšál

$m m \hat{u}, \mathbf{I} 72$

mudd, 30, 43, 47, 79

mmúdda (lés-) dyālt l-mra,

239, 282

múdden, 28

mudállal, I 29

mujahédin, 34I

mûnbar, I 39 sq. ; l-ğrâma

f̆ l-múnbar, 140

$m \bar{u} s \hat{u} f u, 97$

muzûna, 33; muzûnt z-

ẓ̣̇̂̂rt, 33

mwầlin l-blàd, 296 
miállma (l-) den-ngâgef, I 32 ; mállma l-hännáya, I 37

nắqa (n-; nqa), 90

naqd, náqda, 66, $82 n^{3}$

$n \bar{a} s, n a ̈ s, 54,138$

$n \hat{a} j a, 4$ I

$n \hat{a}^{\hat{e}} n a^{e}, 24$

nbârặk (mbârặk), 95 sq.

$n b i(n-), 126,129$

nggâafa, plur. ngâgef, 25 ,

$27,28,132-134,137-$

I $4 \mathrm{I}, \mathrm{I} 56, \mathrm{I} 65, \mathrm{I} 66, \mathrm{I} 68$,

193, I 94, 22 5-229, 275-

279, 301 ; l-miállma denngâgef, 132

nhār l-árbạ in, 304 ; nhār d-dbêha, 78, I41 ; nhār l-fary, I 34 ; nhär lëftôr, 279 ; nhär lặ-g்sîl, 277, 279; nhär hall r-ras, 276; nhãrl-hăzạm, 293 ; nhãr d-djwâari del'arûșa, 78, 146; nhār l-kmäl, 31, 70; nhär lmämla, $3 \mathrm{I}$; n-nhār lménsi, $28 \mathrm{I}$; nhār n-nqa del-‘ărûs, 78, 89; nhãr r-rkub del-'arrûs, I 29; nnhãr s-sába del-earûs u del-ărûșa，293，295 ; nhär s-sbah, 227, 274; nhàr tsaqbib, 136 ; nhär t-tsetwiff, 279 ; nhār tî̀ l-fary, 279; nhär zzîna, I34 sq.; nhär l- ammậiya, I 29, I95; nhär l-örs, 1 40, 261 $n^{1}$, $274,276,277,299$

nikäh, I 5 ; 'aqd en-nikāh, 15

nqa, nằa, 77, 78, 89 sq.; l-hdîya den-nqa del-qauts, 77 ; nhär n-nqa del-cărûs, 78,89

$n s a, 338$

$n s \bar{a} b, n s \bar{a} b, 3$ I 2

$n s i b, 3$ I I $s q$.

nsîba, 3 I 2

nùșs mqáddạm, 66 ; nùș mwáhhar, 66

nwâla, nwậla, I 58, 238, 306 ; hámmàm n-nwâla, 306

qâdi, lĕ-mḥ̆dkma del-qâdi, 28

qadi, I 6

qáftān, qåftãn, 143, 225 , 237

qáse $a, 30$

qáulets, 236

qauts, l-hdîya den-nqa delqauts, 77

qbar, 236

qdãm, 126

qimar, qmar, 98, I 38

qmújja, 158

qrås, 133

grâsel, 277

qrónfĕl, 305

qtib, 100

qwạbel, 229 
qwâleb kbar, I 37 ; qwâleb s'gār, I 37

ráha, bits r-ráha, I 40

rähîya, 147,198

râjel, 55

ras, 90, 276 ; hall r-ras, 276

ráuda, I 29

rbett $\left(r_{-}\right)$, IO2, I04, I 47, I $48,260,290,354$

rêhan, I00

reke àt, 244, 250, 25 I, 255 , 350

réšwa, 35, 79, 80, 303

rfềsa, 34, 238

rígif, 34, 23 I, 233, 279,

$280,29 \mathrm{I}, 292,370$

rjel, 165

rkub (r-) del- 'ărûs, I 29 ; nhār r-rkub del- 'ărûs, I 29

rma, I69

rsul, 236

rụs, häbb r-rụs, 303

salâm, salậm, slām, släm, $2 \mathrm{I}$, 30, I 29, I 39, 250 satrwal, sárwal, 228, 236, 275

sdaq (sdaq), 65

sder, 275-277

sĕbnîya, 3 I, 82, IO3, 228 séksu, 33, 34, 36, 43, 45, 83,9 I, IOI, I 46 , I 54, I 58, I 73, I 78, I 8 I, I 84 , 197, 198, 204, 2 I 6, 2 I 7,
2 I $9,236,238,240,244$,

245,25 I , 285, 298, 305,

$307,322,327,35^{8}$

sëlhäm, 99, I 06, I I I, I 74,

I 75, I 98

séltsa, 277

sënbel, 305

sfäif, I 34 sq.

shor, 236

sîdi, 3I 7 ; sîdna, 233

sīfatsu, $9^{8}$

sîyid, 296, 305

slām, släm. See salâm

swak, 83

sâba, 195

sâbröh (s-) del-`ărûs, 279

sadäq, 65. See sdaq, sdãq sahha, I 29, 35 I

sbah, I 59, 227, 236, 238 , $265,274,279$; s-sbah, I 59 ; sbah bưsiyąr, $23^{8}$; s-sbah del-ărûsa u del'arûs, 279; l-gáșa dẹssvah, 236 ; nhär s-sbah, 227,274

șbôhi, 275 sq. ; tsâletts șbôhi,

276 ; tŝ̂̀ni șbôhi, 276 sdaq, sdäq, 30, 3 I, 52, 53 , 64-67, 69-7 I, 73-75, 77, $82,83,84 n .{ }^{1}$, IO2, I 33 , I 69, 229, 260, 265, 303; sdaq ma'y $\hat{u} f a, 66$ $\operatorname{sha} \bar{a} b, 25,226$ shhâfa, I 67 som $a, 28$ sốndùq, 3 I 
súlțan, 97, 233 sq. ; lgrâma deș-șúlțan, 234 ; l-hâjjeb dess-súlțan, 97 svah. See sbah

צanbūr, 82

צarr, 136

Yarbîya, 82

Yeh, צệh, 32, 262, 3I8 ; uqîit $\zeta-\zeta \bar{e} h \bar{c}, 262$

Yeitan (Y-), Yitan ( $(Y)$, Yîtan

$\left(\xi_{-}\right), 98,338,359$

צq०q, 82

รúlya, I 32

ร̌wär, 84

$t^{s} a b$ hêra, I 33

tạbiêda (t-), 34

$t^{s} \ddot{a}$ dyef, I 45

tåhrij, 88

$t^{s} \hat{a} l e t t^{s}$ șbọhi, 276

tsalmệta, plur. tlâmat, I 34

tsâni șbôhi, 276

$t^{s}$ ánqil, I33 sq.

tsáqqab, tqqab, 27 I sq.

tsaqbib, nhär tsaqbib, I 36

trarj, 294

t’àsyar, tăsyer, 88

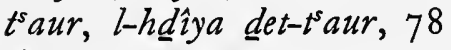
tăzyîna, 283

ta' rêja, tsa'rêja, I05, I73

$t^{5} a^{\text {cyêq, }}$ I 39, 1 94, 364

tsbark alláh, I 38

tsekka, tsekka, 226, 232

t'emsîya, 95

tsetrwif $(t-)$, nhär t-tsetwit,

279

ts $\dot{g} a ́ r b i l, 9$ I tlâmat. See tsalmẹta

tsmar (t-) l-mějhûl, I 38

tqqab. See tsáqqab

$t^{s} q a \bar{a}$, I 5 I

tsqwîsa, l-h̆dnna be t-tsqwîsa, I 37

$t^{\text {srid, }}$ I 7 I, 196, 2 16, 2 I 7 , 362

tริ̂ิ\}a, I 97, 2 I6, 2 I 7,322 , 327

t'argîba, 60

tabbâla, 95, 145, I69;235 tabbâlats, 27, I 33, I 37 I 40, 274-276

tabbầlin, 227

táifor, plur. tiâfar, 132, I33, 228

tájin (t-) del-ăâûs, $29 \mathrm{I}$

takkûk, 32

tan tầya, $30^{\circ}$

țâsa, I 32

ță âm, 9 I, I 73, I 97, 238, $305,306,365$

then $(t-)$, $9 \mathrm{I}$

tiâfar. See táifor

tîoh l-fary, 279

ûdù (l-) l-kbir, 232 ; l-ûdu $s-s g e r, 232$

ûjahh, biád l-ûjah, I93

$\bar{u} k \hat{\imath} l, 40$

uqîit Y̌-šẹh, 262

uzîr, 97, 102, 235

uzîra, I 48

wali, I 5, I6, $86 n .^{3}$; wâli, 296 
wazâra, 97, 98, I I 8, I 25I 28 , I 30, I 42-I 45, I69, $230,233^{-2} 35,280 s q$. wĭld, 23 I

wúzâra, 274

wúzra,.97, I 42

yiblis, I $27, \mathbf{1} 29$

yidd, $\bar{\imath} d, 98, \mathrm{I} 00, \mathrm{10} 3$

yislän, y̌̌slän. See islạn

zarbîya, 31, IO2

záwia, 23

zebbâla, 54

zein. See zin

zérda (z-) dyäl L'ărûșa,

I 7 I

$z$ ĕtțāt, $8 \mathrm{I}$

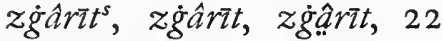

$n .^{2}, 33,35 ;$ muzûnt

$z-z \dot{g} \hat{g} \mathbf{r} \bar{t}, \quad 33$

ziâra (z-) del-carûșa, 302 zin, zein, I 29, I 38, I94;

nhär z-zina, I 34 sq.

zlạfa, IO3

$z l \hat{f} f a$, IO I

$z$ tâta, 81

'abd, $4 \mathrm{I}$

'ădûl, 52, 67, 69, 70, 229

'ăgûza, 30I, 338

'ahd, 145, 259, 260, 355

'ăkàr, 83

'ălàm, I $26 n$.

'amm;'ámmak, 'ámmi, ámmu,

$54,55,90,35 \mathrm{I}$; bĕnt (bint), plur. bnäts, 'amm, $54,55,56 n .1,90$ 'amâma, 'amâma, 77, I 29 'ammärîya, I 29, 167-170, 195, 197 ; nhàr l'ammạrîya, I 29, 195

'ămór, 275

'aqd en-nikāh, I 5

'ăqid (l-) del-hâyệk del'ărûșa, I 42

'âqtin, 338

'àr, 38, 42, 45, 46, 5 I, $60,61,63,282,319$, 339

'árab, I 26-I 28, 233-235, $279-282,367$

'ăráis (plur. of 'ărûsa), I 38 , I 42, I 60 ; hắtțaflă- ráis, 160

'ărîs, 86, I 32, 227 ; lġrâma al lă-erîs $f$ Y̌súlya, I 32

'äs (ërs), $85,90,173$

'arû́s, 25, 86, I I 7, 226 ; l-ı̂̀la del-earûs, I I 7 'ărûsa, 86

'ărûs, 86, 95, I 29, I 72, 279, 29I, 293; l-lîlět del-cărûs, 95 ; nhär n-nqa del-ărûs, 78,89; n-nhär s-sába del-ärûs u del'ărûsa, 293 ; r-rkub del'ărûs, I 29 ; s-sâbröh del'ărûs, 279 ; s-sbah del'ărûsa u del-ărûs, 279 ; t-tájin del-cărûs, $29 \mathrm{I}$ 'ărûșa, 86, I 27, I 42, I 44, 
1 46, 1 7 I, 2 59, 2 79, 293, 302 ; l-bdü u l-ăgid delhâyẹk del-carûsa, I 27 , 142 ; lă-ǵglîya del- ărûsa, I 44, 259 ; lă-h̆zậm dy ăl lă-erûsa, 293 ; l-lîla lkbîra del-àrûsa, I 46 ; llîla s-sgêtra del-‘̆rûsasa, I 44 ; nhar d-djwâri del'ărûssa, 78, I 46 ; n-nhār s-sábae del-‘urûș u del'ărûșa, 293 ; s-șbah del'arûșa u del-arûs, 279 ; z-zérda dyäl l-‘arûsa, I 7 I z-ziâra del-earûsạa, 302 'assel, I 38

'dskar, 274 'âsar, I 30, I 82

'at'aq, 329

'arwáid, 282

'azâra. See 'dzri

'azzîz, 97

'dzri, plur.azâara, 104, 329, 359

iörs, 85 , I 3 I, I 32, I 40, I 73, 193, 225, 227, 228, 26 I n. ${ }^{1}, 274-276,279$, 299, 3 I 4; dār l-örs, I 3 I, I 32, 1 93, 22 5, 227, 228, 274-276, 279, 314; nhär l-örs, I40, 26 I n. ${ }^{1}, 274$, $276,277,299,329$ 'óda, 4I '̌a $($ lát-), 30I 'üd qmâri, I 33 


\section{INDEX OF BERBER WORDS}

(INCLUDING BERBERISED FORMS OF ARABIC: WORDS)

adeblij, ademlij, 91, го6 $a^{d d} j a l, 332$

diduggal, 3 10 afan, $37 n$. áfran, 92, 94, 332; ass úfran, 92, 332 áfssai $n$-ih̆f, 252 ; áfssai $n$ tdikŭst, 253 afttall, 43, I 78, I8 I, 204206, 298

agŭrram, 339

aǵaras, 184

áheddun, 106

dhămmar, 201, 207

àhazzam, áhazzam, 69,

239, 24I, 294; ass

ủhazzam, 294; țáruyi

ühăzzam, 24I ; tiruyi

n-úh̆̌zzam, 239

aheidus, 36

ahläs, $6 \mathrm{r}$

dihrir, I 53-1 55, 242 ; izüd óhrir, I 53, $33 \mathrm{I}$

ahărfi ahựmmi, $20 \mathrm{I}$

ahred, ahrüd, I 52, 176

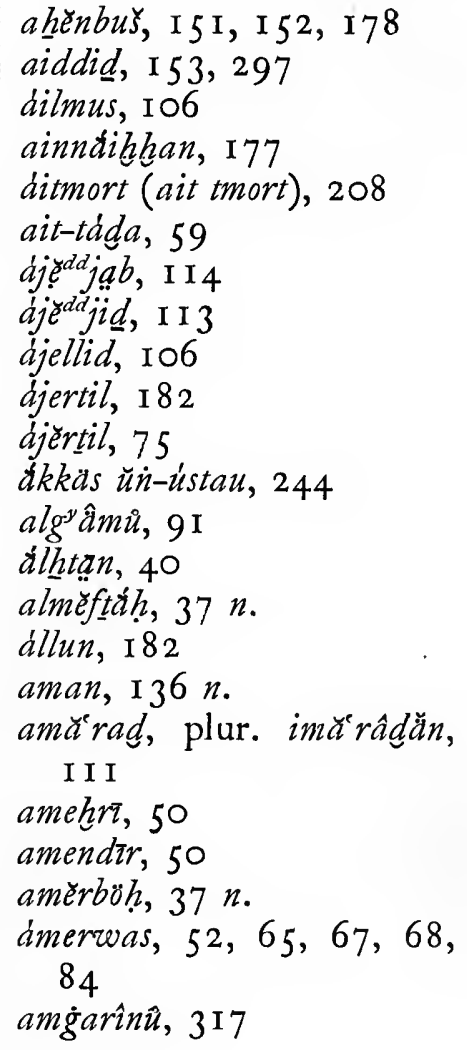

atenbus, $151,152,178$

aiddid, I 53, 297

dilmus, I06

ainndihh han, $\mathrm{I} 77$

ditmort (ait tmort), 208

ait-táda, 59

dje $e^{d d} j a ̣ b$, I I 4

ajétd jid, I I 3

ajellid, 106

ajertil, I 82

ajęrtil, 75

dkkäs $\breve{u} \dot{n}$-ústau, 244

algy $\hat{a} m u \dot{u}, 9 \mathrm{I}$

álhtann, 40

almęftáh, $37 n$.

állun, $\mathrm{I} 82$

aman, $136 n$.

amărad, plur. imărâdăn,

I I I

amehri, 50

amendir, 50

amërböh, $37 n$.

dimerwas, 52, 65, 67, 68,

84

amg்arîû, 3 I 7 
ámidun, 204, 24 I

amsnai, ámsnäi, plur. imsnein, imsnéin, I I 2, I 5 I, I 55 , I 75, I 76, I 79, I 80, 200-202, 204-206, 223 , 239-24 I, 273, 287, 288, 314,346 ame $\hat{a} r q a b, 60 s q$. andalb, plur. ind̆laběn, 52, I 57

ándû, 207

áqsiri, 43

arägn, I 83 sq.

ass n-tmắgra, I 74 ; ass n-yizüd, 92 ; ass úfran, 92, 332 ; ass ühăzzam, 294

asariy, I 52

asêfŭd, 307

asfad, I 76

as ğût $r, 22 n^{2}, 39,4 \mathrm{I}, 44$, 80 , I 10

áslham, I I I, I 75

dsli, plur. islän, 86, I I 3

dssri, 86

astau, I 48, 244 ; ḋkkäs $\breve{u} \dot{n}-$ ústau, 244

asûdĕn ihff, 307

dsun, 106

așăbbd̆h, 202

atqqăf, I 5 I

duzir, 94, I I 3, I 82, 248 , 249,308

dyyur, I 52

d́zellum, 247, 248, 26I

dzigylal, $20 \mathrm{I} s q$.

azqaq, II 5

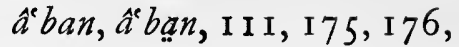

I 79, 273, 332

d̈raben, 285

bặttư, 93

bûrbahh, $37 n$.

$d z z$ ệa 249

dabhẹt, 340

ddhadmit, 250

damăgra, 86, I 83

didqdeht, I 3 I

dárzeft, 309

dásébnit, 286

dásrit, 86

dd $z$ ățāt, 8 I

dhâtend, 286

didli, 72, I 3 I, $25^{\circ}$

diuzîrin, I 55 sq.

firu, 250

iberrăhăn, iberrăhăn, 106, I07, I I 2, I 55

ibúrhsěn, 290

if йgg ăgy en, I 5 I

ig̊ss, plur. igssan, $5^{8}$

iğwîs, 94

ihärkûsĕn, I I 4

ih̆ărgy $\bar{d} n, 176$

ihf, 252, 307 ; afssai n-ihf,

252 ; asûdĕn ihf, 307

$i h s$, plur. ihsan, 67

ihniun, I 54

$i \bar{h}^{\circ} a b, 37 n$.

imahudâben, 46 sq. 
imă râd̆̆n, I I I

imsnein, imsnéin. See ámsnäi indálabern. See andalb

insélmĕn, I 54

insi, $37 n$.

inyän, 208

isš̆gy $n i, 37 n$.

islan, islạn, islạn, islän, (plur. of asli or isli), 86 , I I 3, I 83, I 85,2 Io, 2 I 8, 249, 284-286, 327, 333 ; see Index of Arabic words; múmmi n-islan, I 85

isli, 86, 102

ist-táda, 59

isŭggi, 254

iswi, I I $2,287 \mathrm{sq}$.

iuzî̀ẹ̆n, I I 4, I I 5, I 30, I 3 I, 2 I I

izrîrạn, I 53, 295

izüd, 92, I 53, 33 I ; izüd óhrir, I 53, 33I ; ass nyizüd, 92

izzydrn, 20I

lăgrâmĕț, lägramt, I I I, I I 2 , I 55

lahămas. See lhaims

lajwad, I 84

lárba'. See rrbae

llâtoh, $37 n$.

lbầrwihn, 48

lbélg்at, 69

lbérda't, I 8 I

lëfdît, 60

lẹgwășty, 286 lěhdît n-tslit, $24 \mathrm{I}$

lemdûd, I 82

lěmsếht

lfâtha, 39, 80

lflus n-șbah, 242 ; lfüs nssèrwal, $25 \mathrm{I}$

lfțor nĕ-ssérwal, 246

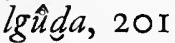

lg̀râma, 24 I, 254

lhăna, I90, 201

lhăbáq, I 84

lhánna, I I 7, I 57, I 78, I 90,

252 ; üd në-lhd̆nna, I I 7 ,

I 57,252

lhánni támqqrant, 109 ; lhănni támzziant, 105 , I 10

lhăzám, I 52, 178

lhorôm, 339

lhàms, plur. lahămas, 67

lihra, 79

liqqâma, 84, I 85

lizār, lizār, I 52, I 54, I 57 ,

I 63, I $78,183,248,249$,

$25 \mathrm{I}$

lizârat, 69

lmān, 20I

lmäun, $37 n$.

lmswạh, I 53

lqandil, 202

lqobbt, I 48

luhhil, 40

lukîl, lükil, 52, 72

luzîr, Io6, 2 I 2, 244-246,

$25 \mathrm{I}$

luzîra, I 56, I 84, 2 5 I, 297

lwásun, 201 
leâda, 2 I 2

$l^{e} a \underline{d} a, \mathrm{I} 76,200$

$l^{e} d k k^{y} a r, 153$

l'ánșart, $35 \mathrm{I}$

múmmuิ n-islan, I 85

nnógra, 83

nnwār, 178

'́rba', plur. lárba', 58, 62 rréhiț, I 50, 178

rfrus nẹt-ssram; 250, $262 n .^{2}$

rhănni amáqqăran, I 15 ,

I 56

Frha, 202

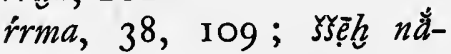
rrma, 38

rršut $\underline{t}, 80$

ssdaq, 65, 72 sq.

ssérwal, ssérrwal, 246, 25 I ;

lflüsn-ssërwal, $25 \mathrm{I}$; lfțōr

$n \breve{e}$-ssérwal, 246

sshör, 176

ssiba $n$-tslit, 294

ssltan, I 55

ssräm, rfrus në́-ssram, 250 , $262 n^{2}$

sriwriwen, $22 n .^{2}, 50$

sșbah, 202, 240, 242, 248

sq. ; sșbah n-ținttot, 249 ;

șsbah n-tslit, 240; lflus

$n$-șbah, 242

ssdaq, 45, 65, 71, 72, 80, 246 ssdaq, 38, 39, 41, 65, 69, $7 \mathrm{I}, 75,76,79,80$, I ro,

I 54, I 8 I, 243

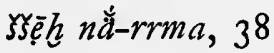

taberdôt, I 82, 207

tábhert, 340

tágrurt, $\mathrm{I} 84$

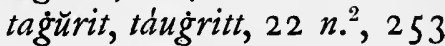

tahlast, I 8 I sq.

tdhrirt, I 49, I 8 I

tåidurt, 45

td́kŭst, 253 ; áfssai n-tákŭst, 253

tálmărjẹlt, plur. tálmärjlin, 212, 297

tamg்art, 339 ; tamg்artinû,

317

támg்ra, 85, $2 \mathrm{I} 3$; $\ddot{u} d$ ntígra, 2 I 3

tamzitt, 106, I 82, 208

tändutt, I07, 207

táqbilt, 57

táqnust, 107, 308

tärfist, 244, 362

tárga, 209

tärkizt, 246, 299

tárrzeft, 308

td́sebnist, 107, 209

táslit, 86

tásěnbưst, 209

táuǵritt. See tag்ŭrit

tigimmi, 184

tiğausîwin, I 84

tiherkûsin, 148

tililau, $22 n .^{2}, 45$, 7 I 
timssi, 208

tislit, 86

tţâmir, 40

túggas, 84

tummit, 297 sq.

tûrift, I 82, 246, 362

tabärda, I 5 I

táda, 57-59; ait-táda, ist-

táda, u-tádda, ult-táda, 59

täfant, $37 n$.

tag $g^{v}$ rurt, I 49, 242

tágrart, 75

táğ $\breve{u} \underline{d} a$, plur. tig் $\underline{d} w \pi n$, I 52

taheddunt, I $52,24 \mathrm{I}$

tahläst, $6 \mathrm{I}$

tahrett, I 76

tádd jalt, $33 \mathrm{I}$

tälméftăht, $37 n$.

tällunt, 9I

țámdwilt, 309

tamēnșīrț, I 52 , I 78

țámgra, támắgra, 85, 86,

I 74 ; ass n-tmăgra, I 74 tamttot, sssbah n-tínttot, 249 táqbilt, $58 \mathrm{n}$.

táqbust, 47

taqbbut, 175

tarrhalt, I 52

tariht, I 79

tárrselt, plur. tírsä̈l, 202

táruyi úh̆azzam, 24 I

tárzeft, $307 \mathrm{sq}$.

tárzzift, 307

täasärutt, $37 n$.

tásěbniht, plur. tisěbnîyin, 69 , I I 3 țd́sěbntt, I 52, I 78

táslit, 86

tásarqit, 249, 309

tás dat, I 52, I 76

taúnza, 204

tázallit $n$-tslit, 205

tázîult, I 53

tămamt, 69, 75-77, 79,

243

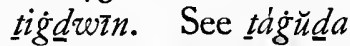

tíğurátin, tíğưrâtin, $22 n{ }^{2}$,

$$
4 \mathrm{I}, 24 \mathrm{O}
$$

timrit, 178

timsútrin, 37 sq.

timst, I 78

timuYit, $22 n .^{2}, 48,75$,

I 82

tiqordîyin, 47

tírrsäl. See tárrselt

tíruyi $n$-úhăzzam, 239

tisěbnîyin. See tásěbniht t

tislit, 86, 202, 205, :240,

$24 \mathrm{I}, 294$; lehdît $\underline{t}$-tslit,

24I ; ssibäa n-tslit, 294 ;

sşbah n-tslit, 240 ; tázal-

lit $n$-tslit, 205

tismmit, 240

tisoğněst, I 54

tiswit, 288

trīht, 2 IO

țúglèlt, túǵglilt, 206, 210

túmlilt, $37 n$.

tutsit, 77

țada, 57

tțââ $\hat{a}, 36,92$, I 54, 240, 307

tráttsa, $246 s q$. 
üd, I I 7, I 57,2 I 3, 252 ; üd ne-lhtinna, I I 7, I 57 , 252 ; üd n-tḿgra, 2 I 3

$\dot{u}^{y} n u, 240,288$

úlli, $20 \mathrm{I}$

ult-tdd $a, 59$

umlil, $37 n$. úrar, 86

$u$-tadda, 59

wârșsbah, $37 n$.

$z z^{\circ}$ afran, zzafrān, I 52,

I 53, I 78 


\section{GENERAL INDEX}

'Abd-el-Aziz Zenagui, $17 n$. $^{2}$

Abd-es-Salâm el-Baqqâlli, Shereef, 5

'Abdullah al-Ma'mun Suhrawardy, I 6 $n^{4}, 64 n .^{1}, 66 n^{1}$ sq., $85 n^{1}, 359 n^{1}{ }^{5}$

Abēla. See Eijūb Aběla

Ablutions, I I 5, I 59, 232, 234, 244, $250,251,255,266,269,270,335$

Abrahams, Israel, $26 n$. $^{1}$

Abreu de Galindo, Juan de, $272 n$.

Accentuation, 13

Addison, Lancelot, $87 n_{*}^{4}$, I $21 n^{1}$, $151 n_{\text {., }}$ I $62 n$., I $68 n^{1}, 2$ I $5 n^{1}, 2$ I $6 n$.

Adultery, $73,328 n^{3}$

Aeneze, I $8 n .^{2}, 59 n .^{\mathrm{I}}, 74 n .^{2}, 268 n .^{1}$

Afra, $67 s q$.

Agal-wood, 133

Aglu, 3, 4, 86, 125, 335; dowry in, $68 \mathrm{sq}$.; payment to the bride's brother in, 81 ; fetching of the bride in, 81 , 183 sq.; painting of the bridegroom with henna in, 117 ; ceremonies in the bride's home in, $15^{6}$ sq. ; arrival and reception of the bride in, 212 sq. ; meeting of the couple and the morning after in, 250 sqq. ; end of the wedding in, 297 ; later taboos in, 310

Ahaggar, 16 $3 n^{3}, 215 n^{1}, 223 n^{2}, 255$ $n .{ }^{\mathrm{I}}, 289 n$.

Ahl el Shemál, $74 n^{2}$

Ahnet, $218 n \cdot 0^{1}, 222 n 0^{3}$

Aid Daud, 58

Ait Ărrba, 67

\section{Hăssan, 57, 209, 246}

Támø̇ldu, 3, 86, 125 ; betrothal among the, 5 I sq.; dowry among the, 68 ; nnoqra among the, 83 ; liqqâma among the, 84,185 ; fetching of the bride among the, 87 , I 84 sq.; cleaning of the corn which is to be used for the wedding among the, 94; painting of the bridegroom with henna among the, 117 ; painting of the bride with henna among the, 157 ; arrival and reception of the bride among the, 213; meeting of the couple among the, $252 \mathrm{sq}$.; continuation and end of the wedding among the, 289 ; later ceremonies among the, 309 sq.

Ait Ugdat, 67

Waráin, 3, 4, $22 n_{*}^{2}, 86,26$ 1-263, $298,299,328 n .^{3}, 336,340$; betrothal among the, 44 sq.; runaway wives among the, 61,63 ; dowry among the, $65,71,72,80,246$; payments to other members of the bride's family than her father among the, 80 ; fetching of the bride among the, 80 , 87, I 8 I $s q . ;$ the bridegroom's hennaceremonies among the, 105 sqq.; tours made by the bridegroom and his bachelor friends among the, ro8, 109,286 ; the bride's henna-ceremony among the, 148 sq.; arrival and reception of the bride among the, 207 sq9.; meeting of the couple and the morning after among the, 243 sqq.; chastity of girls among the, 246 , $328 n^{3}$; continuation and end of the wedding among the, $286,287,290$, 291, 293 sq.; later ceremonies and taboos among the, 308, 31 1, 315, 317 . See Ait Hắssan

Ait Arrba', 58, 62

- Bráhim, 58 sq.

— Frígwu, 62

—- Hấlli, 58, 62

— Händ u 'Äli, 58

-_ Măblûf, $5^{8}, 59,62$

Meśớúd u'Ali, 62

$\mathrm{Nder,} \mathrm{3,} \mathrm{5,} \mathrm{60,} \mathrm{86,} \mathrm{262,} \mathrm{263,} \mathrm{340;}$ betrothal among the, 41 s 99 .; brotherhood among the, 57 sq.; runaway wives among the, $6 \mathrm{r}$ sq.; tămamt among the, 76,243 ; dowry among the, 76, Iro, 180, 181, 243; 
cleaning and grinding of the wheat which is to be used for the wedding among the, 92'sq.; the bridegroom's henna-ceremony among the, 110; the bride's henna-ceremony among the, 149; fetching of the bride among the, 180 sq.; arrival and reception of the bride among the, $206 \mathrm{sq}$.; meeting of the couple and the morning after among the, $242 \mathrm{sq}$.; chastity of girls among the, 243; relations between the bride and her "vizier" among the, 273 ; continuation and end of the wedding among the, $284,285,290,293$ sq.; later ceremonies and taboos among the, $307,308,310,311,314$ sq.; second marriages among the, 332 sq. See Ait Wälläl

Ait Sádděn, 3, 4, 12, $22 n .^{2}, 37 n$., 86, 315,337 ; betrothal among the, 3541, 80; dowry among the, 38,39 , 41, 71,80 , I 54 ; brotherhood among the, 57-59; runaway wives among the, 60 sqg.; rršüt among the, 80 ; fetching of the bride among the, 87 , 174 sq9.; cleaning and grinding of the wheat which is to be used for the wedding among the, 9 I sq.; painting of the bridegroom with henna among the, 110 sq9.; ceremonies in the bride's home among the, 152-155, 175 ; arrival and reception of the bride among the, r99 sq9.; meeting of the couple and the morning after among the, 239 sq.; continuation and end of the wedding among the, $287,288,290,293,294,297$ sq. ; later ceremonies among the, 306 , 307,314 ; second marriages among the, $331 \mathrm{sq}$.

\section{— Wälläl, 58}

- Wäryấgäl, 3, 22 n.2, 86, 190, 191, I 95 sq.n., 336, 340; betrothal among the, 49 sqq.; dowry among the, 50, $65,72,73,79$; gifts sent to the girl's father among the, 78 sq.; dáaăttāt among the, 81 ; fetching of the bride among the, 87,183 ; grinding of the wheat which is to be used for the wedding among the, 94 ; painting of the bridegroom with henna among the, I1 3 , I1 5 ; ceremonies and taboos to which the bridegroom is subject among the, $113-116,130$ s9.; tours made by the bridegroom and his bachelor friends among the, 114,286 ; meeting of the couple and the morning after among the, 114, I I5, 249 sq.; ceremonies in the bride's home among the, 155 sq.; arrival and reception of the bride among the, 2 ro sqq.; continuation and end of the wedding among the, 286 ; later ceremonies and taboos among the, $300,309,311$; second marriages among the, 333

Aiț Yăhya u Yusf, $5^{8}$

$\longrightarrow Y$ úsi, 3, 5, $22 n .^{2}, 61 n ., 85,86$, $95,125,340$; brotherhood among the, 57-59; runaway wives among the, 61 sq.; ceremonies in the bride's home among the, 149-152, 178, 242; chastity of girls among the, 151 sq.; fetching of the bride among the, $178 \mathrm{sqg.;}$ arrival and reception of the bride among the, 203 sqg. ; meeting of the couple among the, 240 sqg.; intimacy between the bride and the imsnein or amsnäi among the, 240, 241, 273 ; painting of the bridegroom with henna among the, 242 ; continuation and end of the wedding among the, 288-290, 293-295, 297 sq.; later ceremonies and taboos among the, 314; second marriages among the, 332. See Aid Daud, Ait Ärrba', Ait Bráhim, Ait Frígwu, Ait Hấlli, Ait Händ u Ăli, Aiț Măhlûf, Ait Més ớúd u 'Áli, Aiț Yăhỵa u Yusf, Aiț Zż xihum, Ehinájęn

Zi zihum, 59

Albania, $255 n .^{1}$

Alcazar, 6, $20 n_{.}$, I $17 n^{2}, 168 n^{2}$

Aleppo, $17 n_{*}^{2}, 84 n_{\text {., }} 18 n_{*}^{1}$, $125 n_{\text {., }}$ $222 n^{2}$

Algeria, $17 n^{2}$, I $\delta n^{2}, 56 n ., 59 n^{2}, 7^{6}$ $n ., 77 n .^{1}, 118 n^{1}$ and $n .^{3}, 124 n^{3}$, $160 n_{0}^{1}$ sq., $161 n^{3}, 188 n .^{2}, 215 n^{2}$, $216 n ., 218 n, 221 n^{2}, 223 n .^{1}, 255$ $n .^{1}, 264 n ., 266 n .^{1}$ sq., $267 n .^{3}, 268$ $n .^{1}$ sq., $293 n^{2}, 313$ sq. $n .^{2}, 367$ sqq. See Beni Snùs, Constantine, Mazourra, Tlemcen, Ouargla

Al-Hijaz, $74 n .^{2}$

Ali, 122

Al-Meydānt, $55 n .^{1}$

Almonds, 1 58, $182,212,214,2$ 16, 250,277 Alvise Cadamosto, $272 n$.

Ameer Ali, $15 n .^{1}, 16 n .^{2}$, I $7 n^{1}$ sqq., 30 $n ., 64 n^{2}$ sq., $65 n .^{2}, 84 n, 86 n .^{3}$

Amzmüz, 3 ; dowry at, 67 ; arrival and reception of the bride at, 95, 214 ; ceremonies in the bride's home at, 157 ; fetching of the bride at, $185 \mathrm{sq}$.; meeting of the couple and the morning after at, 254 
Andjra, 3-5, 191, $218 n^{2}, 261,263,265$, 291, 315, 336, 351 sq.; betrothal in, 29 sqq.; dowry in, 30, 31, 52, 70, 169 ; hdîya in, 30,77 sq.; written contract of marriage in, $3 \mathrm{I}, 52$; marriages between cousins in, 53,55 ; hláwa in, 81, 169; fetching of the bride in, $81,87,168$ sqq.; šwär in, $83 \mathrm{sq}$. ; cleaning of the corn which is to be used for the wedding in, $88 \mathrm{sq}$.; the bridegroom's henna-ceremony in, 95 sqq.; other ceremonies to which he is subject in, 125 sqq.; ceremonies in the bride's home in, 142 sqq.; painting of the bride with henna in, 144 s9q.; arrival and reception of the bride in, 194 sq.; meeting of the couple and the morning after in, 230-235, $257,258,260,265,266$; continuation and end of the wedding in, 279-28I, 291-293, 295 sq.; later ceremonies and taboos in, $300,302,31 \mathrm{I}$

Animal ridden by the bride, the, subject to certain ceremonies, r94-196, 201, $205,207,211,214,218,219,327$, 348,357 sq. See Camel, Mare, Mule, Stallion

Antagonism between different social groups, 224, 345 sq. See Fights

Antimony, 105, 120, 153, 161, 176, $193,202,233,242,266,282,283$, $295,306,322,327$ sq.

Arabia, $120 n^{2}$ and $n 0^{4}, 160 n^{1}, 161 n .^{2}$ sq., 163 sq. $n .4$, 315n. See Al-Hijaz, Bedouins, Haḍramaut, Mecca, Medina, Mount Sinai

Arabic sounds, rendering of, 11 sqq.

Arabs, the ancient, $10,18 n^{2}, 19 n_{0}, 59$ $n^{\mathrm{I}}, 220 n^{\mathrm{I}}$; marriages between cousins among, $53 n_{0^{2}}, 54 n ., 55 n^{1}$, 55 sq.; mahr and șadāq among, 65

"Arabs" of Morocco, 2-4, 56, 57, 62, 166, I67, 339 n.I, 367. See Beni Ahsen, Dukkâla, Garbîya, Hiáina, Hilot, Rahámna, Tlìq, Ulẳd Bü-Ăzîz, Ǔlẩd Jâma', Ulẩd Râfa

Ardeshir, $56{ }^{2} .^{2}$

Arg, 34i

Arvieux, Chevalier d', $120 n^{2}$ and $n^{4}$, 160 n. ${ }^{\mathrm{I}}, 161 n^{2} \mathrm{sq}, 3^{15} n$.

Asylums, women as, 339

Aț Á már, 2

- Buzéggu, 2 ; támamt among the, 76

Lmệdi, 2

Shbèl, 2

Ubáhti， 2, 3, $22 n^{2}, 86,318$, 353 ; betrothal among the, 45 sqq.; țämamt among the, $47,69,75,76$, 79 ; dowry among the, 69,79 ; lihra among the, 79 ; cleaning and grinding of the wheat which is to be used for the wedding among the, 93 sq.; the bridegroom's henna-ceremony among the, 112 sq.; meeting of the couple and the morning after among the, I 3,248 sq.; the bride's hennaceremony among the, 155 ; fetching of the bride among the, i 82 sq.; arrival and reception of the bride among the, $209 \mathrm{sq}$.; chastity of girls among the, 249; curious behaviour of the best-man among the, 273; continuation and end of the wedding among the, 285, 286, 290, 291, 293 sq9.; later ceremonies among the, $308 \mathrm{sq}$.

At Yäla, 2

- Yiznásen, 2 ; țámamt among the, 76

Zíhri, 2, 7 n.; early marriages among the, $48 \mathrm{sq}$.; endogamy of the, 57 ; defloration of the bride among the, 272

Atkinson, J. J., 374

Atkinson, James, I5 5 n., 221 n., 255 $n^{3}$

Attica, $124 n^{2}$

Aubin, Eugène, $6 n{ }^{2}$

A vebury, Lord, $220 n^{2}, 317 n$.

Avoidance customs, explanations of, 312 sqq.

- of brothers-in-law, 3 10 sq9. of parents, 22, 40, 48, 288, 313 sq9:

_L of parents-in-law, 307, 310 sqg.

Azila, 34I

Bäb 1-Gîsa, 54

Bachelor friends of the bridegroom, the, take part in the grinding of the wheat which is to be used for the wedding, $92,94,320$; accompany the bridegroom, 96-99, 102, 106-110, 113 -1 15 , 1 $18,126,128,130-132,148,211$, $230,233,236,239,281-287,346$, 363 ; beat the bridegroom, $(104)$, $107-$ 109, 120, 121, 346; paint themselves with antimony and walnut root, 105 , 120, 202, 282, 327 ; make tours with the bridegroom, $108,109,111,114$, $281-286,333$; beaten by the bestman, 110, 346 ; smear henna on their hands and clothes, I 1 3, 120, 327,360 ; have fights with the married (or older married) men, 126, 
128, 131, 234, 269, 285, 286, 346 ; with the imsnein and women, 204, 223,346 ; with the unmarried women, $237,238,269,346$; with the women, $245,247,261,268,346$; the evil influences of the bride prevented from affecting, 210, 218, 327; put the bride's mother into a net, 246,247 , 349 ; must have a share of a certain dish partaken of by bride and bridegroom, 245, 262 ; receive dates and silver coins from the bride and her girl-friends, $282 \mathrm{sq}$. See Index of Arabic Words, islan; Index of Berber Words, islan

Baganda, 369

Baghdad, $75 n$., $160 n^{1}$

Bajār, 12 I $n .^{1}$

Balkans, the, 368

Bangles, 100, 103, 106, I I 2, 1 24, 154

Barber, the family, 25,132

Barley, $47,67,79,182$; cleaning of the, which is to be used for the wedding, 89 ; offered to the bride, 196, 198, $211,216,217,361$; given to the mare ridden by her, 196, 20r, $207,219,348,35^{8}$; thrown by her on the people, 198, 2 I r, 217, 348, $357,3^{61} \mathrm{sq}$.

Bashfulness of the girl or bride, 22, 23 , $156,163,253,254,265,299,315$, 345 ; of the young $\operatorname{man}, 22,29,32$, $36,42,46,48,114,117,123,126$, $249,252,253,271,289,309-317$, 345

Bath, a public, earth from the entrance of, 28 ; haunted by $j n \bar{u} n, 136$

"Bath, the evening of the hot," 140

Bathing or washing of the fiancée, bride, or young wife, 27, 136, 140, 141, 144. $146,149,151,153,155,156$, $161,162,208,277,296-298,301-$ $303,305,306,321,351,354,356$, 363 ; abstinence from, $114,115,290$, 324; of the bridegroom, 118,120 , $126,127,155,228,266,321$; as a cure for sterility, $35^{\mathrm{I}} \mathrm{sq}$. See Ablutions

Beans, 50,79

Beating, smacking, or tapping, of the bridegroom, 104, 107-109, 120, 121 , $198,199,223,25^{2}, 256-258,323$, $356 \mathrm{sq}$.; of the bride, $157-159,162$, $214,217,223,235,237,244,248$, $250,256,323,35^{6} \mathrm{sq}$. ; of the bridegroom's tent, 200, 204, 218,327

Bedouins, $55 n^{2}, 56 n^{1}, 74 n^{2}$, I6 6 sq. $n^{3}, 163$ sq. $n{ }^{4}, 188 n .^{\mathrm{I}}, 2$ I $5 n^{1}, 265$ $n^{2}$ sq., $289 n, 291 n_{0}{ }^{2}, 339 n_{0}^{1}$ See Aeneze, Áhl el Shemál, Al-Hijaz, Beni Șaher, Haḍramaut, Moab, Mount Sinai, Shammar

Bees, 337, 340

Bel, A., $166 n$.

Belt, $69,82,84,1_{7} 8$; the bride wearing no, 146, 148, 237, 244, 263, 264, 324, 331; the bride's, 152, 210,249 , $253,260,282,286,325,354$; the bridegroom wearing no, 225, 264 , $281,293,324,350$; opening of a woman's, 262 ; the young wife's, $304 \mathrm{sq}$.

"Belt, the day of the," 293 sq.

"__ the opening of the," 159,237 , 239, 241, 244, 253, 262 sq.

Belting of the bride, $292-295,298$, $325,331,348,35^{\circ}$; of the bridegroom, 293

Benhazera, Maurice, I63 $n_{0}^{3}, 215 n^{1}$, $223 n .^{2}, 255 n_{0}^{1}, 289 n$.

Beni A ḥsen, $339 n^{1}$ Mgild, 6 I $n$.

Mțer. See Ait Ndẽr

Sádděn. See Áit Sádděn

Saher, $164 n$.

Śnūs, I $18 n .^{1}, 25^{6} n .^{2}, 263 n .^{1}$, $266 n^{2}, 294 n ., 314 n$.

- Ulîd, 27 I sq.

Waráin. See Ait Waráin

Wäryâgääl. See Ait Wäryâgäl

Berber sounds, rendering of, $12 \mathrm{sq}$.

Berbers, 2-5, 10, 59, 60, 328, 339, 367 sq.; marriages between Arabs and, 56 sq.; marriage by purchase among the, 77. See At Buzéggu, At Zíhri, At 'Àmár, At Shb̄èl, At Lmêdi, At Yiznásen, At Yála, At Ubảhtî, Brâber, Dráwa, Ruâfa, Shloḅ

Bertholon, L., 367 sqq.

Best-man, the, 94, 97-99, 102-104, 106 $110,113,119,120,127,128,130$, $182,230,234-236,242,244-246$, $248,249,251,265-267,272,273$, $282,285,286,308,315$; smears henna on his own hands, 98,113 , I 20, 327, 346

Betrothal, Chap. I. p. I 5 sqq.

Bhâtsa. See At Ubáhți

Biarnay, S., $160 n^{1}$, I 6 I $n .^{1}, 265 n .^{2}$, $289 n$.

Bissuel, H., I9 $n_{\text {., }} 218 n^{1}{ }^{1}, 222 n^{3}$

Black cloak, the b-idegroom dressed in a, 114 ; assuming a, 253

man, the animal on which the bride is taken to her new home led by a, 184, 187. See Negroes 
Black woman, the bride attended by a, 141, 156, 194, 227, 276 sq. See Index of Arabic Words, nggâfa

Blessings, 24, 25, 31, 43, 44, 48, 103$105,107,112,132,138,140,199$, $208,226,284,287,364$; pronounced on the bridegroom, 95-97, 128, 129, I 55, 199, 231, 232, 244, 248, 258, $275,280,347$; on the bride, 159, 194, 195, 199, 200, 232, 248, 250, $258,292,347$. See Index of Arabic Words, fâtha

Blood, as a prophylactic or means of purification, $210,219,262,263,294$, $295,305,327$; of a fowl or pigeon, as a substitute for hymeneal blood, $229,240,241,243,246,248,270$; haunted by $j i \bar{u} n, 343$. See Hymeneal Blood, Menstruation, Virginity -letting, 337

-revenge, $44,80,116$; a cause of early marriages, 49 ; of polygamy, 328

Boulifa, See Saïd Boulifa

Boy, a, paints the bridegroom with henna and accompanies him, 113, 114, 119; ceremonies supposed to promote the birth of, $154,155,168$, $172,(174-176,179,181,185), 191$, (192), 200-202, 221, 222, 292, 293, 297 ; shut up inside the bridal box, 168 ; riding the animal on which the bride is going to be taken to her new home, 172, 175, 191, 192, 349 ; riding behind or in front of her on the same animal, 172, 174, 176, 179, $181,185,191,349$; leading the animal on which she rides, 183 ; riding on it alone round the bridegroom's house after the bride has been lifted down, 211,218 ; or boys, belting the bride, 292, 293, 350 ; gives her water to drink and washes her face, $297,35^{\circ}$

"Boys, the threshold of," 201, 221 sq.

Brâber, 2-5, 65 ; marrying women from Arab tribes or $\mathrm{Fez}, 57$; runaway wives among the, $60 \mathrm{sqq.;}$ chastity of girls among the, 243. See Ait Waráin, Ait Ndēr, Ait Sádděn, Ait Yúsi, Beni Mgild, Zémmur

Bracelets, 83,91

Brand, John, $216 n$., $257 n^{2}$

Bread, 46, 50, 88, 90, $170,181,194$, $231,233,243,250,251,253,277$, 291, 292, 295, 296, 299, 302, 307$310,322,323,347,362$; thrown on the bridal box or the bride, 195, 213 ,
$216,217,358,361$; applied to her when girdled, 292 ; offered to her and other women when she goes to fetch water, $297 \mathrm{sq}$.

"Breakfast, the," 278

"___ of the drawers, the," $246 \mathrm{sq}$.

Breaking, of an egg, 8, 1 31, 1 51, 195, 218 , $218 \mathrm{sq} . n^{2}$; of the henna bowl, 99, 101, 108, 109, 121, 149, 162, 323; of earthenware vessels, 121,343 ; of a mug, 131, 323

Bridal box, 53, 70, 81, 129, 166-170, $189,195,197,322,323,325,326$, 345,363 ; bread and dried fruit thrown over the, 195, 197, 216

- procession, 165 sq9., 326 ; considered a cause of ill-luck, $190 \mathrm{sq}$.

"Bridal box, the day of the," 129, 195

Bride, the fiancé dressed up as a, 25-27, 323 ; Arabic and Berber names for, 86 ; the young wife dressed up as a,

301 , the, haunted by evil spirits, 26 , 27, 160, 187, 188, 237, 255,256 , 321,342 ; imitating the appearance of a man, $27,152,153,163,174$, $187,188,323$; protected from the evil eye, $27,138,150 n_{0}^{1}, 165,168$, $187-189,213,217,321-323,326$, $35^{8}$; accompanied by women dressed like herself, $27,165,187,323$; taken to the bridegroom's place in a bridal. box, 53, 70,81, 129, 166-170, 189, $195,197,322,323,325,326,345$; if not found to be a virgin, 71,73 , $159,229,230,232,236,240,243$, 246, 248-250, 252-254, 270 ; silver coins worn by or offered to, 72, 73, $146,147,150,157,162-164,174,191$, 207, 250, 258, 262 $n^{2}, 322,347,357$; days for fetching, $86 \mathrm{sq}$. ; her dress, 92, 142-144, $146,148,15^{2-1} 54,156-$ $158,163,174,175,178,187,188$, $194,250,261,275-277,321,323$; grit thrown on, $95,214,320$; ceremonies supposed to make the husband fond of or prevent him from quarrelling with, 101, 1 $36,143,147,158,164$, $170,235,236,258,260,355$; receives money from the bridegroom inmediately before or after the connection, $113,159,237,239,241,242,244$, $248,251,253,262,263,325$; after he has coiffed her, $248,261,325$; when he meets her, $250,258,262 n^{2}$; after he has girdled her, 294,325 ; on other occasions, $148,152,155$ (261 $\left.n .^{1}, 276,325\right)$; ceremonies supposed 
to make her fruitful, $127, \mathbf{1 2 8}, \mathbf{1 4 3}$, (153), 1 54, I 55, (162), 164, 168, 1 72 , (174), 175, (176, 179), 180, (181, 185), 191, (192), 195, 200-202, 221 , $222,230,232,244,246,247,255$, $25^{8}, 269,292,293,297,348-35$ r, (353); ceremonies in her home, Chap. IV. p. 1 36-164, 329; bathing or washing of, $136,140,141,144,146$, $149,151,153,155,156,161,162$, 208, 277, 296-298, 321, 354, 356, $3^{6} 3$; painted with henna, 136,137 , $141,142,144^{-1} 5^{1}$, I 53-1 58, 1 60-164, $175,178,185,188,242,252,295$, $320-322,332,333,353,355$; accompanied by unmarried girls, 137, 139 $142,144,145,155,156,158,169$, 1 84, I $97,208,346,363$; has her face covered, $137,138,142,147,148,152$, $156,163,172,174,179,181,184$, $185,189,196,203,212,219,296$, $299,322,325,326,345$; danced about on a smałl table, $137,138,194$; keeps her eyes closed, 138, 194, 275 ; ceremonial giving of money (ǵấma) in her home, $138,139,142,146,148$, $149,155,164,347$; kissed by her mother, 138 sq.; the presence of women guests supposed to bring good luck to, I39, 364; mounted on a platform receives presents from guests and relatives, I 39 sq. ; carried, I4I, $144,145,148,163,168,169,172$, $174,181-185,188,189,195-198$, $201,205,207,208,210,212,214$, $219,220,220$ sq. $n .^{2}, 223,324,345$; attended by a black woman, 141, 156 , 194, 227, $276 \mathrm{sq}$.; ceremonies and observances supposed to make her remain in her new home, 14 I, 149, $150,161,169,170,172,179,189$, I $90,202,208,222,349,353$ sq. ; seated on a mattress, 142 ; dressed in the hây $k$ sent by her betrothed, while its fringe is being plaited, 142, 143, 260, 265, 354 ; crying, 143-1 45, I 49, $157,163,169,172,174,354$; liable to be robbed by the married women, I 44, 346; does not eat much, I 44, $196,212,323$; dressed in fine or new clothes, I 44, 146, 148, $15^{2-154, ~} 15^{6}$, $157,175,178,194,250,275-277$, $32 \mathrm{I}$; sends food to the bridegroom, 144,355 ; makes tours with her girlfriends, 145, I $55 \mathrm{sq}$; milk offered to or sprinkled on, 145, I64, I70-174, $177,180,182,183,185,190,194$, $203,207,210,212-216,218,326$,
$347,357,361$; hospitality given her in the houses she visits with her girlfriends, 145,156 ; wears no belt, 146 , $148,237,244,263,264,324,331$ ( $c f$., on the other hand, 210 ); mounts the sheep which is to be slaughtered and boxes its ears, 146, 1 57, 1 58, 330 , 355 ; ceremonies performed with a view to making her dear to the bridegroom's family, 147, I50, 164, 209, 217,357 sq.; has the backs of her slippers pulied up, I 47-1 50, 1 56, I 59, $163,290,323,331$ sq.; her glance dangerous to others, $148,163,172$, 181, 189, 219, 326; has her hair dishevelled, 148, 169, 172, 247, 261, $264,291,321,328,331$; her headgear, 148, 172, 211 , 235, 256, 277 ; swords crossed over her head, 149,155 , 162,$322 ;$; new slippers put on her feet, 150,321 ; a needle put into her right slipper, $150,162,237,290$, 322 ; an egg tied round her forehead, I 5 I ; ceremonies intended to facilitate the defloration of, $151,152,164$, 177, 179, 192, (232, 264 sq.), 348; appoints her imsnein, 151 ; ceremonies supposed to give her power over her husband, $151,157,158,164,198$, $199,223,235,244,252,256,257$, $330,355 \mathrm{sq.;}$; dressed in clothes sent by the bridegroom, $152-154,156,157$, $175,178,261$; carries a dagger, 152 , 163,322 sq.; a circle painted with saffron on her li $\approx \bar{a} r, 152,322$; grinds wheat over her uncovered right thigh, $153,162,353$; painted with saffron, $153,154,161,242,243,266,295$, 322 ; with antimony and wainut root, 1 53, 16 I, 193, 242, 266, 275, $283,295,322$; with ochre, 153 , $193,275,283,295$; ceremonies practised with a view to making her a mother of sons, $154,155,168,1,2$, (1 74-176, 1 79, I 81,185 ), 191, (192), 200-202, 221, 222, 292, 293, 297, 348 sqq.; appears bashful, 156,163 , $253,254,265,299,315,345$; confined to her dwelling, I 56, $157,16_{3}$, $29 \mathrm{I}, 323$; tapped by her brother with his slipper, I 57, 1 62, 323; smacked, tapped, or beaten by the bridegroom, I 58, I 59, 1 $62,235,237,244,248$, $250,256,323,356$ sq.; performs a ceremony intended to prevent her husband getting angry with her, 158 ; marks of her virginity, 1 59, 228, 230 , $232,233,236,237,239-243,245$, 
$246,248-254,266-268,362,368$; the defloration of, announced by the bridegroom pulling up the backs of his slippers, $159,251,253,254,266$; by his sending dried fruit to her parents,

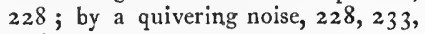
$236,237,240,242,245,249,253$, 267,322 ; by shooting, 233, 236 , $237,240,242,245,249,251,253$, 266,322 ; by her dabbing a small spot of blood on either cheek, 246 ; aimed at by witchcraft, 172, 173, 179, 324 ; performed by somebody else than the bridegroom, 271 sqq.; blessings pronounced on, 159, 194, 195, 199, 200, 232, 248, 250, 258, 292, 347 ; ceremonies intended to purify or protect, 160-163, 290, 29I, 321 sq9. ; baraka attributed to, 160, 171, 179, $183,190,191,195,196,205,208,211$, $217,245,246,302,331,359$ sq9.; held to be very susceptible to harmful supernatural influences, $160,289,290$, $321,342,360$; fetching of, Chap. V. p. 165 sqq.; dragging her foot, 165 , $36_{3}$; guarded against witchcraft, 165 , $172,173,175,176,179,185,187$, I 88, 324 ; avoids the sight of water, I66, I87, 324; the sight of her dangerous to others, $169,189,326$; stones thrown after, 169-171, 173, $176,177,179,180,190,323,326$, 353,357 ; ceremony said to cause her to take her evil with her, 170, I90, 326 ; ceremonies said to make her a good wife, 170, 174, I9I, 211 , 222, 357 ; ceremonies supposed to rid her of evil influences, 171,177 , 190, 191, 194, 195, 197, 203, 207, 208, 21 4-218, 321 sqq., 357 sq. ; ceremony said to make her happy in her marriage, I7I; ceremony intended to make her husband die and cause her to return to her old home, 171 sq.; must not turn her head, 172, 1 89 , 295, 324, 353 sq.; the proper time for her arrival at the bridegroom's place, 173, 175, 182, 222, 320 ; dressed in a man's cloak, 174, I 88 ; gives money to the person who spreads his cloak or hây $\ell_{k}$ in front of her, $175,176,179,191,361$; avoids stepping on the ground, 176, 179, $185,188,189,212,324$; ceremony said to make her and the people round her carry away the evil of the village, 176,177 , 190, 326 ; sprinkled with a mixture of henna and water,
177, I90, 326; receives presents from the bridegroom, 178, 276, 279; sprinkled with water, $180,203,209$, $215,216,326,347,348,357$; her beauty liable to be taken away by her mother, I 8 I sq.; sweet-scented plant carried in front of, 184,188 ; must not tread on the threshold, 185,189 , 219,220 sq. $12 .^{2}, 324$; crosses a river three times to and fro, $185,190,326$; taken three times round a shrine, 185,186 , 190, 326 ; regarded as a source of danger to others, 191, 200, $201,203,204,208,210,215-217$, 219,325 sqq., 360 ; arrival and reception of, Chap. VI. p. 193 sqq.; painted with hárgos, 193, 275, 283; with biád l-ûjäh, 193, 275; kissed by the bridegroom's mother, I94; the animal ridden by her subject to certain ceremonies, I94-196, 201, 205, 207, 211, 21 4, 21 8, 219, 327, 348, 357 sq.; ceremony said to make her a blessing to her husband, 194, 195, 357 sq.; bread thrown on the bridal box or, $195,213,216,217,35^{8}, 361$; dried fruit thrown on the bridal box or, 195, 197, 206, 209, 212-214, 216 , $217,320,353,35^{8}, 361$; must not be seen, 195, 198, 219 ; barley offered to, 196, 198, $211,216,217,353$, 357,361 ; throws it on the people, I $98,211,217,348,357,361$ sq. ; $t^{8}$ rid offered to, 196, $216,217,353$, 362 ; throws it on the people, 196 , 217,362 ; kisses the head of the person who lifts her into the nuptial chamber or tent, 196, 207; taken round the bridegroom's house or tent, 196-198, 200, 206, 209, 215, 326, $33 \mathrm{I}$; round the mosque of his village, $199,200,203,208,215,326,331$, 332,349 ; round his village, 203, 215,326 ; țăâm offered to, 197, 216, $322,327,353$; throws it over her head, $197,217,322,327$; wheat offered to, 197, 198, $216,217,322$, $327,353,357$; throws it over her head, 197, 217, 322, 327, 357 ; on the people, 198, $217,348,357$; flour offered to, 197, 207, 214, 216,322 , 327 ; throws it over her head, 197, 207, 208, 217, 322, 327 ; tร̌šsa offered to, 197, 216, 322, 327,353 ; throws it over her head, $197,217,322,327$; sprinkles water on the people, $198,216,348$; smacks or tries to smack the bridegroom with 
her slipper, 198, 199, 223, 252, 256$258,323,330,356$; robbed, 200 , $204,223,325,346$; performs a religious ceremony, 200, 205, 208, 2 I 4, 218,349 ; beats the bridegroom s tent with a cane, 200, 204, 218, 327, 331 ; flings the cane at it, 200, 205; smears butter on the horizontal pole supporting its roof, 201, 205, 207, 221 ; performs a ceremony said to make the corn plentiful in the household, 201, 219, $35^{8}$; taken to the four corners of the bridegroom's tent, 201, 202, 221, 222, 348 sq.; one of the tent-poles put into her lap, 202, 349 sq. ; must not eat publicly, $203,207,221,240,241,273,323$; must refrain from speaking or speaking aloud, 203, 207, $212,221,244$, $253,295,323$; must not be spoken to, 203, 324; red raisins offered to, 204, 216, 353, 358; throws them over her head, 204; hurls a lamb over the bridegroom's tent, 204, 221 , 361 ; omens indicating whether she will rule over her husband or vice versa, 205, 252, 321 ; the amsnäi dancing with her seated on his shoulder, 206 ; the bridegroom's mother offering her aftäl on her uncovered thigh, 206 ; ceremony supposed to make her and her motherin-law friendly to one another, 206 , 222, 357 ; receives a coin from the man who lifts her into the bridegroom's tent, 207 ; sprinkles milk on the people, 207,361 ; throws dried fruit on the people, 208,362 ; kisses her mother-in-law, 208 ; her right foot and hand washed over one of the fire-stones, 208,354 ; ceremony intended to make her fond of the cattle, 208, 222, 357; her kerchief tied round the head of a donkey, $208 \mathrm{sq}$.; omens indicating whether she will remain with her husband, 208, 209, 247, 248, 321; whether her and her husband's conduct will be straight, 209, 321 ; henna or blood smeared on the saddle in which she has ridden, $210,219,327$; taken between the bridegroom's legs, 211 , 357 ; kissed by the bridegroom, 21 I; water offered her to drink, 21 2, 215 ; henna offered to, 214, 217, 326; the bridegroom attempting to strike, 214 , $217,223,356$; pretends to feel reluctance against marrying, 220 ; gives the bridegroom two kerchiefs and a cord for keeping up the trousers, 226, 260, 26r, 354; threads the cord through his trousers, 227 , 260,354 ; money put on her drawers, 228,269 ; knots made in the cord of her drawers, 232, 264; waves her slipper toward the door of the nuptial chamber, $235,256,35^{6}$; kisses the bridegroom's hand, $235,258,357$; the cane - work of her headgear crushed by the bridegroom, 235,256 , 323 ; if obstinate tied up, 235,239 , $242,244,248,265$; evil spirits expelled from, $237,(25 \mathrm{I}), 256$; one side of her hair plaited by the bridegroom, 237, 247, 248, 261, 355; removes his slippers, $237,258,356$; must not doze, 237, 254, $323 \mathrm{sq}$.; keeps on her slippers at night, $\mathbf{2 3 9}$, $290,323,331$; eats with the imsnein or amsnäi, 240, 24 1, 273,288; kicked by the bridegroom, $242,256,356$; throws her slipper at him, 244, 251, $256,323,35^{6}$; makes resistance, $244,250,251,253,265$; her drawers blown to pieces, 245, 267, 323 ; ceremony relating to the ribbon with which her hair is fastened, 247,248 , 261 ; her belt tied round the bridegroom's head, 249, 260, 354; the bridegroom throwing his slipper at, $251,256,323$; her hair arranged in the fashion of married women, 252, $276 \mathrm{sq}$. ; joins in the dance of the people, 253,268 ; beats the bridegroom with a piece of rock-salt, $25^{8}$; the end of one of her plaits undone by the bridegroom, 261 $n .^{\mathrm{J}}, 276,325$; the relations between her and her "vizier," 273 ; placed on a pile of mattresses, 275 sqq.; her headgear changed, 277 ; receives money from the women of the bridegroom's village, 280; from her mother-inlaw, 28I; gives dates and silver coins to the bridegroom and his bachelor friends, $282 \mathrm{sq}$.; receives presents of food and a hen from him, 285 ; kisses the people visiting her on the head, 285 ; receives money from them, 285 ; her slippers not to be repaired, 290, 325 ; must abstain from bathing, 290,324 ; remains in her seclusion till the sixth or seventh day after her arrival, 29I, 333; ceremonies to which she is subject on this day, 29 I sqq.; avoidance between her 
and her mother, 292, 315 ; kisses her, 292 ; belting of, 292-295, 298, $325,33 \mathrm{I}, 348,350$; ceremonies following upon the belting of, 295-299, $325,348,350$; shy of her parents, 315 ; if she is a widow or divorced wife, $328 \mathrm{sqq}$.; the casting of corn, rice, or salt on the people or on, 343 . See Fiancée, Young Wife

Bride, mock-, 330

- and bridegroom, eat together, IOI, $227,231,237,244,250,251,253$, $25^{8-260}, 275,276,281,355,362$; covenanting between, $144,145,259-$ 261,355 ; meeting of, and the morning after, 1 58-160, I 7 I, Chap. VII. p. 225 sqq.; the more beautiful of them performs the usual ablution before the other, 159, 269, 270, 350; their intercourse postponed, $227,228,241$, $249,250,252,253,270,271,275$; drink water together, 232, 257, 258, 356 ; avoid cleaning themselves with the same towel, $266,35^{\circ}$; have a bath together, 298

"Bride, the," 330

" - , the feast of the," I 7 I

"___ the morning of the," 240

"___, the prayer of the," 205

"—_, the present of the," 24 I

"__, the reverent visit of the," 302

"___, the seventh [day] of the," 294

Bride's brother, the, money paid to, 79$82,169,186,345$; puts a silver coin in her right slipper, 157 ; puts her slippers on her feet, I57; taps her with his own slipper, 157 ; beaten by her girl-friends, I 57 ; lifts her on to the animal on which she is taken to the bridegroom's place, 168, I7 1, 174, 183 sqq.; leads the animal, 17o, I 83 , 187 ; rides with her on the same animal, 174, 176, 184 sq.; spreads his cloak or hayẹk on the ground for her to step on, $175,176,179,191$; receives money from her, 175,176 , 179 , I9I; if grown-up, avoids her during the wedding period, $176, \mathbf{1} 87$, 315 ; lifts her out of the bridal box, I 95,223 ; lifts her into the bridegroom's house or tent, I 97, 2 I I-2 14, 223 ; has a fight with the bridegroom, $210,211,223,346$; rides on the animal round the bridegroom's house, and keeps the bridle, $211,212,218$; refuses to proceed to the door of the bridegroom's house, $213,214,223$, 345
Bride's father, the, does not go to the wedding, 176, 18 1-185, 187, 315 ; cursed by the women, 197, 223, 346 ; avoids his daughter, 315

mother, the, kisses her daughter, I 38 sq. ; drinks milk and eats a date, I 39 ; gives presents to her daughter, I 40 ; gives money to the fqîra, 142 ; paints her daughter with henna, 147149, I6I ; does not accompany her to the bridegroom's place, 170, 17 1, 179, $181,183,184,187,315$; accompanies her to the bridegroom's place, I72, $176,179,181,183,187$; goes there afterwards, 181, 184, 291, 292, 3 10 ; crying, I74; may take away her daughter's beauty, $18 \mathrm{I}$ sq.; gives a meal, I $83,204,236,238,239,243$, 245-247, 249, 268, 269, 292, 299 ; receives money in return, 239, 243, 249; put into a net, 246, 247, 349; subject to a ceremony intended to make her daughter fertile, 246,247 , 269 ; sends her daughter tables loaded with food, 277 sq.; kissed by the bridegroom's parents on the head, 292 ; by her daughter, 292 ; by the bridegroom, 310; blesses her daughter, 292 ; avoidance between her and her daughter, 292, 315

"Bride's beginning and tying of the hâyẹk, the," 142, 143, 260, 349

"L day of the neighbours, the," 146

"__ great night, the," I 46

"__ little night, the," I 44

Bridegroom, Arabic and Berber names for, 86

, the, sends a bullock or calf to the bride's house, 78,146 ; ceremonies in his home previous to the fetching of the bride, Chap. III. p. 85 sqq.; painted with henna, 90, 95, 97-102, 105, 1071 22, 1 24, 1 25, 1 7 1, 1 99, 238,242 , $248,260,321$ sq.; throws grit on the bride, $95,214,320$; blessings pronounced on, 95.97, 1 28, 129, 155 , 199, 231, 232, 244, 248, 258, 275, 280, 347 ; his face covered up, 96, 97, 102, 105, 106, 1 88, I 1 1, 112 , 1 1 4, 1 23, 1 26, 1 28, 1 31, 175, 198, $225,233,239,250,254,266,282$, $283,287,289,314,315,322,345$; accompanied by his bachelor friends, 96-99, 1 02, 1 06- 1 1 0, I 1 3-1 1 5, 118 ,

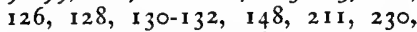
233, 236, 239, 28 I-287, 333, 346, 363 ; regarded as a sultan, 97,102 , 106, I 1 $3,118,274$; carries a sword,

$2 \mathrm{D}$ 
97 n., 99, 102, 106, 108, 111 1 123 , $235,237,239,242,244,251,255$, 282, 290, 322 ; must not eat much, $99,123,323$; must not eat or drink in public, 99, 123, 1 30, 234, 323 ; dressed in a white cloak, 99, 106, I I I, 1 24, 253, 347, 357 ; his dress, 99, 102, 106, I1 1, I1 4, 115 , $120,124,126.128,225,227,253$, 260, 261, 291, 321, 324, 347, 354, 357 ; swords crossed in front of him or over his head, 99, 104, 106-109, $112,123,322$; seated on a skin-sack, $100,102,103,106,123$; on a carpet, $102,106,123,130$; on a saddle, 105, 115,123 ; on a chair, 132; on a mattress, 227 ; ceremonial giving of money ( $\dot{g} r a m a)$ in his home, 100, 103105, 107, 109, I I I I I 3, I 16, 124 , $125,132,226,227,234,254,269$, 347 ; subject to the ceremony called $r$-rbet, 102-104, I19, 322; has his head shaved, 102, 106, $120,127,130-$ 133, 321; dressed in new clothes, $102,120,128,225,321$; wears new slippers, 102, 120,321 ; wears slippers bought with money out of the bride's share of the dowry, 102, 260, 354; pulls up the backs of his slippers, 102, I O9, I I I, I I 2, I 14, I 23, I 24, I 59, 251, 253, 254, 266, 290, 323 ; beaten by his bachelor friends, (104), 107109, 120, 121, 323, 346; by men and women of the bride's village, 198 , $199,223,323,345$ sq. ; by the bride, $198,199,223,25^{2}, 256-25^{8}, 323$, $330,35^{6}$; by the women assembled outside his house, $211,223,323,346$; charms worn by, 104, 10.5, 123, 290, 322 ; painted with antimony, 105, $233,242,266,282,322$; with walnut root, $105,242,266,282,322$; makes tours with his friends, 108, 109 , I I 1, I 1 4, 281-286, 333 ; carried or lifted, 109, 110, 123, 1 28, 130 , 132, 133, 324; gives money when painted with henna, III; carries a pistol, 112, 123, 248, $255,290,322$; baraka attributed to, I13, I I 8, I 21 , $125-127,359$ sqq.; gives money to the bride immediately before or after the connection, 1 1 3, 159, 237, 239, 241, 242, 244, 248, 251, 253, 262, 263,325 ; after he has coiffed her, 248, 261, 325 ; when he meets her, $250,258,262 n^{2}$; after he has girdled her, 294, 325 ; on other occasions, 148 , I 52, I 55, (261 n.1,
$276,325)$; appears bashful, 114,123 , 126, 289, 310, 345; dressed in a black cloak, I1 4, I24; praying, I14, I $15,130,230-232,234,244,250$, $251,255,266,280,323,350$; abstains from bathing or washing, 114 , I $15,290,324$; performs an ablution, $115,159,232,234,244,250,251$, $255,266,269$ sq.; abstains from changing his clothes, I15, 291, 324 ; confined to his house, $117,123,281$, $286,289,323$; shy of his parents, I 1 7, 249, 252, 253, 27 1, 288, 313 sqq.; bathing or washing of, 118 , $120,126,127,155,228,266,321$; purified or protected from evil influences, 1 I 8-124, 289-291, 32 I sqq.; surrounded by supernatural dangers, 1 18, 1 19, 289, 290, 321, 334, 342, 360 ; carries a dagger, $123,211,250$, 256, 322 ; wears a kâyẹk, the fringe of which has been plaited in the bride's home, 126, 127, 143, 260, 354; washed clean of his henna, $126 \mathrm{sq}$.; attacked by the married men, 126,128 , 1 31, 233, 234, 269, 286, 346; his shaved-off hair, 127, 230, 231, 324 ; wears clothes presented to him by the bride, 127, 354; accompanied by scribes, 128, 130, 198, 199, 280, 357 ; by shereefs, 128 ; performs a religious rite, 129, 323 ; must not speak aloud, 129,323 ; breaks a mug and an egg with a kick, 131, 323; food sent to him from the bride's house, 144, 259, 355 ; sends clothes to the bride, 152 I 54, I 56, I 57, 1 75, 1 78,26 I, 276, 279 ; gives her dried fruit, $15^{8}$; smacks, taps, or beats her, 158,159 , $162,235,237,244,248,250,256$, 323,356 ; tries to get power over his wife, 158, 1 59, 162, $217,232,235$, $237,242,244,250,256,25^{8}, 35^{6}$; his presents to the bride returned if she is not found to be a virgin, 159, 229,236 ; goes to fetch the bride, $167,175,186 n_{*}^{1}$; almost invariably stays at home when the bride is fetched, $168,169,186$; sends various presents to her, 178 ; milk given to, 194; rushes through his tent together with two men dressed like him, 198, 330,356 ; gives money to scribes, 199 ; omens indicating whether his and his wife's conduct will be straight, 209, 321 ; sham-fight between the bride's brother or uncle and, 2 I0, 2 I 1, 223, 346 ; the bride taken between 
his legs, 211, 357 ; puts her down on the bed, 211 ; kisses her, 211 ; gives a silver coin to every woman guest at the wedding, 212 ; throws dried fruit on the bride, 212-214, 216, 320 ; throws bread on her, 213, 216; attempts to strike her with a cane, $214,217,223,356$; wears no belt, $225,264,281,293,324,35^{\circ}$; mounts a ladder, 225 ; receives from the bride two kerchiefs and a cotd for keeping up the trousers, 226, 260, 354 ; sends dried fruit to her parents, 228 ; if he falsely accuses her of not being a virgin, 229 sq.; kisses his parents' heads or hands, $230,280,288$; steps over the bundle of old clothes containing his shaved-off hair, 231, 324; must not look back, 231, 250, 255, 324 ; performs certain water ceremonies, 231, 232, 255, 321 ; makes a recitation from the Koran, 232, $255,266,323$; blesses the bride and himself, 232 ; asks God to bless him with children, 232, 244, 258; unties seven knots made in the cord of the bride's drawers, 232, 264; kissed on the head by the bride's haddáy n, 233 ; gives money to them, 233 ; robbed, $233,234,269,286,325,346$; does not speak, $234,244,255,323$; cuts a rope, $235,237,256,323$; kissed by the bride, $235,258,357$; crushes the cane-work of her headgear, 235,256 , 323 ; burns incense, 235, 237, 244, 255, 322; expels evil spirits, 237, $\left(25^{1}\right), 256$; throws away the needle which has been put in the bride's slipper, $237,256,323$; plaits one side of her hair, $237,247,248,261,355$; the bride removing his slippers from his feet, 237, 258, 356; keeps his slippers on his feet at night, 239, 290, 323 ; has a meal with the imsnein, 241; kicks the bride, 242, 256, 356; the bride throwing her slipper at, 244,25 r, 256, 323, 356; makes fâtha, 244, 250; the bride's belt tied round the crown of his head, 249,260 , 286,354 ; greets the bride, 250 ; puts his right foot over the threshold of the nuptial chamber before he makes his entrance by a third step, 25 I, 254, 255,324 sq. ; throws his right slipper at the bride, $251,256,323$; fires off his gun, $25 \mathrm{I}, 253,266,322$; joins in the dance of the people, $25^{1-253}$, 268,323 ; if he finds the bride to be a virgin, 251-254, 266, 268; if he finds her not to be a virgin, 252-254, 270; puts on a black cloak, 253; undoes the end of one of the bride's plaits and puts on her hair a silver coin, 26r n. ${ }^{1}, 276,325$; takes care that no offspring can result from the defloration of her, $265,266,350$; the defloration of her performed by somebody else than, 271 sq9.; gives a banquet, $278 \mathrm{sq}$.; remains with the bride, 28I, 286, $33 \mathbf{I}$; and his bachelor friends receive dates and silver coins from the bride and her female friends, $282 \mathrm{sq}$.; one of his bachelor friends imitating his dress, 284; and his bachelor friends go out to hunt, 286 sq.; receives dried fruit and silver money from his sisters and female cousins and friends, $287 \mathrm{sq}$.; gives the donors money and blessings in return, 287 sq.; does no work, 289 ; has a needle in his right slipper, 290, 322 ; his slippers must not be repaired, 290, 325 ; must not have his head shaved, 290, 324; resumes his belt, 293 ; gives a garden party for his friends, 293 ; kisses the bride's mother on the head, 310; if he is not a bachelor, 328 sqq.; slaughters a sheep or goat, 333. See Fiancé, Young Husband

"Bridegroom, the earthenware dish of the," 29 I

"__ the evening of the," 117 sq.

"__, the ride of the," 129

"__._ and bride, the seventh day of the," 293

Bridegroom's brother, the, goes to fetch the bride, $168,169,171,172,181$, 182,184 ; lifts her on to the animal on which she is taken to her new home, 172, 181, 187; gives her a silver coin, 174, 191, 207, 357 ; if a little boy, rides the animal on which she is going to be taken to her new home, 175; if grown-up, must not see her, 178,186 ; lifts her into the bridegroom's house or tent, 196-198, 207, 208, 223; kissed by her on the head, 196, 207 ; tied up by the married men, 280

father, the, avoided by his son, 48 , 313 ; distributes wheat to be ground for the wedding, 94 ; takes the money given at his son's henna-ceremony, $100,104,109$; receives presents of food from guests, IOI; avoids his son, 106, 279, $3^{1} 3$ sq.; does not go to fetch 
the bride, $165,169,172,178,180-$ 184,186 ; goes sometimes to fetch her, 169, 172, 180; cursed by the women, 197, 223, 346 ; gives barley to the bride on her arrival, 211 ; kissed by his son on the head or hand, 230, 280, 288; blesses him, 231, 280 ; examines the ribbon with which the bride's hair is to be fastened, $24^{8}$; takes part in a banquet with his son, 279 ; kisses the bride's mother on the head, 292

Bridegroom's mother, the, blesses her son, $97,231,280$; carries a bundle of her son's old clothes with his shaved-off hair inside, 1 27, 1 28, 230, 247, 349 ; performs ceremonies supposed to make the marriage fruitful, $127,128,154$, $195,199,222,230,247,269,348$ sq. ; dresses the bride, 154 ; does not go to fetch her, I $69,17 \mathrm{I}, \mathrm{I} 82, \mathrm{I} 84,186$; goes to fetch her, 172, 175, 178, 180 sq.; leads the animal ridden by her, 172, 176 ( $c f$. 179); kisses her, 194; drinks milk and eats a date, I94; ceremonies with which she receives the bride, 194-198, 201, 202, 204$210,212,213,216-219,221,222$, 357 sq.; carries a sieve on her back, 195, 199, 247, 349; gives dates and incense to scribes, 199 ; robbed of her headgear, 200, 223, 346 ; ceremony intended to make her and her daughterin-law friendly to one another, 206, 222, 357 ; kissed by the bride, 208 ; by her son on the head or hand, 230 , 280,288 ; sups with the bride, 211 ; gives a meal, 280 ; gives a dollar to the bride, 281 ; has her hair dishevelled, 291, 328 ; kisses her mother on the head, 292 ; gives bisiy $\bar{q} r$ to the bride and other women, 297 ; subject to a curious ceremony together with the bride, $298 \mathrm{sq}$.

- sister, the, keeps hold of the point of her brother's hood when he is smeared with flour or henna, 103, 106 ; makes a quivering noise on the same occasion, 103 , 107 ; takes the money which is knocked on his head, 103; paints him with henna, 105, I I2, II9; receives money from the people when he is painted with henna, 107, 112 ; paints the bride with henna, 149, I50, I 6 I

sisters, the, go to fetch the bride, 169, 175; keep hold of the tail of the animal on which the bride is taken to her new home, 176 ; robbed of their headgears, 200, 223, 346; give their brother a present of dried fruit and money, $287 \mathrm{sq.;}$ receive money and blessings in return, $287 \mathrm{sq}$.

"Bridegroom's night, the," 95

Bride-price, 42-44, 47, 75 sqq., 243, 270. See Dowry

Bridle, the, of the animal on which the bride is taken to her new home, 91 , $211 \mathrm{sq}$.

Brotherhood (tada or táda), 57 sq9.

Brothers-in-law, avoided, $31059 q$.

Buhäri, el-, $85 n .^{\mathrm{I}}, 86 n .^{3}, 256{ }^{1} .^{1}$

Bullocks, 30, 33, $77,78,82,125,146$, $3 \circ 3,361$

Buns, 24, 142

Burckhardt, J. L., I $8 n .^{2}$, I $9 n$, $55 n .^{2}$, $56 n ., 59 n .^{1}, 74 n^{2}, 87 n .^{1}$, I $20 n .^{6}$, $163 n .^{4}, 164 n ., 188 n$. and $n .^{1}, 2$ I $5 n .^{1}$, $219 n^{1}, 25^{8} n^{2}, 263 n .^{3}, 265 n{ }^{2}$ sq., $268 n .^{1}, 291 n^{2}$

Burton, Sir Richard F., $17 n .^{2}, 5^{6} n$. and $n .^{\mathrm{I}}, 74 n^{2}, 368,370$

Butter, 24, 29-31, 33, 40, 43, 45, 47, $67,77,78,82,88,171,181,183$, $243,251,308$; methods of making it plentiful, 171, 201, 205-207, 22 I, 347,361 ; smeared by the bride on the horizontal pole supporting the roof of the bridegroom's tent, 201 , 205, 207, 221

Buttermilk, 26I

\section{Cadamosto. See Alvise Cadamosto}

Cairns, 129, 309

Cairo, $19 n ., 74 n^{2}$, I $20 n^{2}, n^{4}$, and $n_{*}^{6}$, I60 $n .^{1}, 161 n^{2}, 219 n .^{1}, 25^{8} n^{2}, 263$ $n .^{3}, 268 n^{\mathrm{I}}$

Calassanti-Motylinski, A. de, $160 n_{*}{ }^{\mathrm{I}}$, $266 n .^{2}$

Camel, the bride taken to the bridegroom's place on a, 168, 173, 174, I $8_{3}$, I 84, I 9 I

Canary Islands, the, $272 n$.

Candles, 29, 40, 43, 47, 78, 97, 98, 104, I $21,122,130,132,136,139,144$, $145,162,166,187,226,230,231$, $248,252,292,295,296,301,322$, 325

Cape Spartel, 34 I

Cattle, ceremonies supposed to increase the, 201, 204, 221, 222, 232,298 , 347 ; sprinkled with water to make the bride fond of them, 208, 357 ; with henna, 303

Celebes, $26 n$.

Central Africa, ${ }^{669}$ 
Ceremonies, motives for, 7-9, 344; the historical origin of, 9, 10, $367 \mathrm{sq}$.

"Chamberlain, the Sultan's," 97. See Best-man

Chantre, E., 367 sqq.

Charity, a method of purification, 295, 298

Chastity of girls, 243, 246, 249

Cheapness, 202, 222, 348

Chemise, hoisted at a minaret, 28 ; a woman dancing with the bride's, $23^{6}$, 241,267 ; dancing round or in the presence of it, $236,240,241,267$. See Virginity

Chenier, $56 n^{4}, 220 n^{\mathrm{I}}$

Cherbonneau, E., $64 n .^{3}, 65 n .^{2}$

Childbed woman, $3^{6} 3$ sq.

Childbirth, knots avoided at, 264; defiling effect ascribed to, $341 \mathrm{sq}$.; attended by all the married women of the village, 364

Children, custody of, x7. See Boys, Offspring

Cleaning of the wheat or corn which is to be used for the wedding, the, 88-95, 319 sq.

"Cleaning of the corn, the day of the," 92

Cloves, 178

Cock. See Fowl

Coin or coins, silver, 347,357 ; sent by the fiancé and put underneath a handmill, $33,152 \mathrm{sq}$.; worn by or offered to the bride, $72,73,146,147,150$, I 57, 162-164, 174, 191, 207, 250, $258,262 n .2,322,357$; painted with henna, 107, 125; given by the bridegroom to the women guests at the wedding, 212 ; walked over by newly bought animals, 2 I $8 n^{2}$; given by the bride and her female friends to the bridegroom and his bachelor friends, 282 sq.; given to the bridegroom by his sisters and female cousins or friends, 287 sq. See Money

Colebrocici, T. E., I $62 n$.

Combs, $83, x_{7} 8$

Compensation for marrying a runaway wife, 60 sqq.

Conder, C. R., $188 n{ }^{5}, 216$ n., $218 n$., $222 n$.

Congratulations, 31, 233, 243, 248, 269

Consent, a woman's, to her marriage, I $5,16,18,19,37,42,44,45,52$, 59 sq.; a son's, to his marriage, 18 , $19,29,34,35,37,41,42,44,46,52$

Consonants, transliteration of, $x$ i $s q$.
Constantine, $162 n_{*^{3}}, 189 n_{*^{3},} \mathbf{1 9 2} n$., $263 \mathrm{sq} \cdot n \mathrm{.}^{3}$

Consummation of the marriage postponed, 227, 228, 241, 249, 250, 252, 253, 270, 271, 275, 314. See Bride and Bridegroom, meeting of ; Defloration of the Bride

Contract of marriage, Chap. I. p. I 5 sqq.; written, $17,52,53,69,76 \mathrm{sq}$.

Corn, may be used in ceremonies for a variety of purposes, 7 ; as hdîya, $3 \circ$, 77 sq. ; ceremonies supposed to increase the supply of, $195,201,216$, $217,219,347,358,361$, see Good Year, Rain ; as a prophylactic, 261 ; must not be polluted, $335,336,339$ sq.; cast on the bride or the people, 343,353 ; in danger of being stolen by $j n \bar{u} n, 343$. See Barley, Durra, Wheat

Cos, $26 n$. $^{I}$

Cousins, marriages between, 21, 23, 49, 53 sqg.

Covenanting, $144,145,259-261,354$ sq.

Cowdung, 37, 269

Cows, $84,303,307,3 \circ 9,336$

Cox, M. R., $257 n^{2}$

Crawley, Ernest, I, 26, 27, $220 n_{*}^{2}$, $221 n .1,270,27 x, 317 n$.

Criers, 100, $105-107,112,132$

Crooke, W., $27 n_{\text {., }} 123 n^{2}, 215 n^{1}, 2$ I 6 n., $220 n^{2}, 221 n$., $255 n_{*}^{1}, 258 n^{3}$

Crossings of streets, earth from, 28

"Crumbs, the," 297

Crying of the bride, 143-145, 1 49, 157 , I $63,169,172,174$

Cuckoo, 32

Curses, 28, 54, 180, 197, 223, 309, 339, 346 ; conditional, 38 n., $63,259,319$, 364 sq. See Index of Arabic Words, 'ar

Customs, local influence on, 4 ; motives for, $7-9,344$; the historical origin of, 9 , $10,367 \mathrm{sq}$.

Dadeh Bazm Ará, $151 n$.

Daggers, 89, 123, 152, 163, 197,211 , $221,250,256,322,35^{6}$

Dancing, 36, 50, 90, 92, 94, 96, 114, $144,178,179,206,211,251,253$, $268,287,314,323,344$; with the henna bowl, $98,99,101,110,121$, $145,149,162,360 \mathrm{sq}$.; of ngâgef with a table on which the bride is seated, I 37 sq.; of the amsnäi with the bride seated on his shoulder, 206 ; of a woman with the blood-stained 
garment of the bride on her head, 236 , 241,267 ; round or in the presence of this garment, $236,240,241,267$; the bridegroom joining in the, $251-253$, 268 ; the bride joining in the, 253 , 268

Dancing-boys, 96

- -girls, 96

Danger attaching to the sexual act, conception of, 1, 26, 27, 271, 334 sqq.

Dates, $25,28,34,52,83,1_{47}, 1_{50}, 1_{5} 8$, $164,183,194,199,209,212-214$, $216,217,226,231,233,241,249$, $251,253,282,283,287,299,302$, 310,364 ; represent wealth, 25,27 , $28,139,164,347$; of Tafilelt, 138

"Day of ambulation, the," 279

"—_ of the bridal box, the," I 29

"_ of the cleaning of the corn, the,"

\section{2}

"

"- of the flour, the," 92

"__ of the girdle, the," 293 sq.

"__ of the morning, the," 274

" __ of the neighbours, the bride's," I 46

"

"__ of the wedding, the," 140, 274

Days, for the celebration of marriages, $86 \mathrm{sq.}$; for the beginning of the autumn ploughing, 87

Dead people, the souls of, 342,344

Death, the dowry in the case of the husband's, $65-68,70-73,76$; practices supposed to cause the husband's, I 71 , 172, 189, 353 sq. ; contagion of, 344

Defloration of the bride, the, ceremonies intended to facilitate, $151,152,164$, $177,179,192,(232,264,265,348)$; announced by the bridegroom pulling up the backs of his slippers, I 59, $25 \mathrm{I}$, $253,254,266$; by his sending dried fruit to her parents, 228 ; by a quivering noise, 228, $233,236,237$, $240,242,245,249,253,267,322$; by shooting, $233,236,237,240,242$, $245,249,251,253,266,322$; by the bride dabbing a spot of blood on either cheek, 246 ; aimed at by witchcraft, 172, 173, 179, 324; sham attempt to prevent, $232,264,34 \delta$; the bridegroom taking care that no offspring can result from, 265 ; performed by somebody else than the bridegroom, 271 sqg. See Consummation of the Marriage, Virginity

Demnat, 2, 6, $117 n^{2}, 252,258$

\section{Descos. See Aubin}

Destaing, E., I $18 n_{0}^{1}$ and $n_{0}^{3}, 256 n_{0}^{2}$, $263 n .^{1}, 266 n .^{2}, 294 n ., 314 n$.

Devil, the, 98 , $122,127,129,255,256$, $323,338,344,359$

Diseases, curing of, 261, 262, 352; caused by $j n \bar{u} n, 343$

Disguises at marriages, $25-27,152,153$, $16_{3}, 16_{5}, 174,187,188,198,199$, $284,323,330$

"Dish of the morning, the," 236

Divorce, easy, I9; the dowry in the case of, $65-73,76,79$; practices supposed to prevent, 141, 149, 150, $161,169,170(c f$. , however, 177), 179, 190, 202, 208, 222, 305, 349, 353 sq.; omens relating to, 208, 209, $247,248,321$; of frequent occurrence, 328

Divorced wife, allowed to dispose of her own hand, 59 ; in her father's power, 59 sq. ; dowry given for a, 66.69, 7 I73,328 ; remarriage of a, 328 sq9.; the wedding of a, 329 sqq.

Dog of the house, the, ceremony to make it friendly with the young wife, 296 , 357

Domestic animals, ceremonies supposed to increase the, 196, 201, 204, 219 , 221, 222, 232, 298, 347 ; ceremony supposed to expel death from the, 200 ; sprinkled with water, 208 ; with henna, 303,362

Donkeys, 209, 340

Doughty, C. M., $33^{8} n$. $^{1}$

Doutté, Edmond, $6 n .^{8}, 7$ n., $23 n .^{1}$, $53 n .1,59 n .1,96 n .$, I I $7 n^{1}$, I I $8 n .^{3}$, I $39 n^{1}$, I $52 n^{2}, 166 n_{0}^{1}$

Dowry, I7, 30, 31, 38, 39, 41, 45, 50, $52,53,64-77,79,80,82,83,102$, I 10, I 54, 169, 180, 1 $81,260,303$, 354 ; for widows or divorced wives, $66-69,71-73,328$; returned if the bride is found not to be a virgin, $7 \mathbf{I}$, $73,229,236,243,246,270$; onehalf of it returned, 246,270

Dozy, R., $96 n ., 139 n_{\bullet}^{1}$, I $66 n_{\text {., }} 168 n^{2}$

Dráwa, 2 sq.

" Drawers, the," 228, 229, 275

"__ the money of the," 251,262

Dress, the bride's, 92, 142-144, 146, $148,152-154,156-158,163,174$, $175,178, \mathbf{1} 87, \mathbf{1} 88,194,250,261$, $275-277,321$; the bridegroom's, 99, $102,106,111,114,115,120,124$, $126-128,225,227,253,260,261$, $291,321,324,347,354,357$; cere monies referring to, 260, 261, 354 ; 
the young wife presenting her mother with materials for a, $30 \mathrm{I}$

Dress, articles of, given by the young man or his parents to his future wife, $24,25,31,39,40,52,82,83,159$, 229 ; given as bride-price, $30,31,69$, $70,75,76,78$; given by the girl to her betrothed, 3 I, I 27, I 43, 354 ; bought with money out of the brideprice, 70 sqq.; given to other members of the girl's family than her father, 80 ; given her by her father, 84 ; given to the bride by guests and relatives, I 39 sq.; to the young wife by her husband, 143,286 ; to the bride by the bridegroom, 1 52-154, $156,157,175,178,261,276,279$; to the bridegroom by the bride, 226 , 260, 26I, 354; taken from the bridegroom by force, 233, 234, 269, 286 ; exchanged, as a form of ' $a h d$, $260 \mathrm{sq}$.; given to the young wife by members of her family, 303. See Belt, Disguises, Hair, Headgear, Slippers

Dried fruit, $7, \mathbf{1} 76, \mathbf{1} 79, \mathbf{1} 81,202, \mathbf{2} 28$, $231,243,288,291-293,295,298$, $302,307 \mathrm{sq.;}$ thrown on the bridal box or the bride, 95, 195, 197, 206, 209, $212-214,216,217,320,353$, $35^{8}, 361$; offered to her, and thrown by her over her head, 204, 216,358 ; thrown by her on the people, 208 , 362 ; sent by the bridegroom to her parents as an announcement of her virginity, 228. See Almonds, Dates, Figs, Walnuts

Druzes, 2 I 7 sq. $n .^{2}$

Dukkâla, 3,82 $n^{2}, 86,263 n^{2}$ See Ulâd BüÁzîz

Dung of animals, 245, 268, 269, 327

Durra which is to be used for the wedding, cleaning of the, $88 \mathrm{sq}$.

Early marriages, 34, 35, 44, 48 sq.

Ear-rings, 83

Earth, from seven different places, 28 ; from a shrine, 305

"Earthenware dish of the bridegroom, the," 29I

Eating ceremonies. See Meals

Eggs, 7, 8, 88-90, 97, I ㅇ I, I I 3, I I 5, I 1 6, $124,131,145,151,164,194,195$, 218,218 sq. $n^{2}, 231,250,260,261$, $277,285,291,293,326,327,347$, $34^{8}, 35^{2}, 353,355,357,3^{6} 3$

Egypt, $17 n .^{2}, 20 n ., 56 n ., 82 n .^{3}, 83$ sq. $n ., 86 n .^{2}, 87 n_{*}^{1}$, I $20 n^{2}$, I $23 n_{0}^{1}$ and $n *^{3}$, I $60 n^{1}$, I6I $n_{*}^{1}$ and $n_{*}^{3}$, I $64 n^{1}$,
$184 n ., 187 n 0^{1}, 188 n^{3}$ sqq., $189 n .^{3}$, $255 n 0^{4}, 267 n .^{\text {I }}, 268 n_{*}^{2}$; Jews of, 26 n. ${ }^{1}$. See Cairo

Egyptian privet. See Henna

Ehinájen, 58

Eijūb. Abēla, $222 n$. and $n{ }^{1}$

Einszler, Lydia, $217 n$.

E1-Buhāri. See Buhāri

Elopements, 36

Emancipation of a daughter from her father's power, 16

Emily, Shareefa of Wazan, $6 n_{*}^{2}$, I 4 I $n .^{2}$. $167 n^{2}$, I $89 n^{1}$, 196 n., $293 n^{1}$

Emotional states, ceremonies as direct expressions of, 344 sq9.

Empty dishes, tables, or trays, avoidance of, $24,25,34,239,24 \mathrm{I}, 249,279$, 287,321

- saddle, avoidance of an, 172,180 , 1 82,192 ( $c f$. on the other hand, I 81 ), $320 \mathrm{sq}$.

Endogamy, 57

England, 2 I $6 n$, $257 n^{2}$

"Entering into the tent, the," 302

Euripides, I $24 n .^{2}$

Europe, Io, I9 $n_{., 2} 6 n^{1}, 86 n^{1}, 87 n^{1}$, $121 n_{*}^{1}, 163 n_{*}^{2}, 164 n_{.}, 215 n_{*}^{1} \mathrm{sq} \cdot$, 2 I6 n., 2 19 $n .1,258 n .^{3}, 268 n^{2}, 328$, $367 \mathrm{sq}$.

"Evening, the great," 142

"___, the little," I41 sq.

"_ of the bridegroom, the," 95, I 7 sq.

- of the hot bath, the, 14I

Evil eye, the, 27, I 19, 123, I 24, 138 , I $50 n^{I}, 165,168,187,189,213,217$, $3 \circ 3,326,338,339,342,35^{8}$

influences, avoidance, expulsion, or destruction of, 91, 99, 101-103, 108, $118-124,131,160-163,170,171$, $177,178, \mathbf{1} 86,188,190,191,194$, $195,197,200,203-205,207,208$, $210,214-221,235,237,245,255$, $256,261-267,289,294,295,298$, 304-306, 321 sqq., 35 I sq.

— spirits, 26, 27, 89, 99, 103, 119, 1 22, 1 $23,160,231,235,237,255$, $256,321,335,342,343,351,352$. $357,358,362$. See Devil; Index of Arabic Words, (d) jnīn

Excrements, human, 343

Exogamy, the origin of, $370 \mathrm{sq9}$.

Fahs, the, 4, 6, $97 n ., \quad$ I $17 n_{0}^{\mathbf{I}}$, I $18 n^{3}$, I $68 n .^{2}, 370$

Falls, J. C. E., $188 n .^{2}$ and $n .^{5}$

Farnell, L. R., $26 n^{1}$

Fasting, 34 I 
Father, avoided by his daughter, 22, 40, 315 ; avoidance between $a$ son and his, 22, 48, 106, 279, 288, 3 1 3 sq9.; arranging his son's marriage, 34 sqq.; a son making no mention of his love to his, $3^{6}$; opposed by his son, 44 ; kissed by his son, $48,230,280,288$, 314 sq.; by his daughter, 302, 303 , $307,308,310$; receives presents from her, 302, 307 ; gives presents to her, 302, 303, 307 sq9.; his slippers kissed by his daughter, 3०3. See Bride's father, Bridegroom's father, Parents

Father's power, the, $15,16,18$ sq.

Fățima, Fățîma, Fațîma, 156, 161, 236, 359

"Feast of the bride, the," $17 \mathbf{I}$

Feasts, religious, 31, 34, 73, I 18

Fehrle, E, 26 n.1

Féraud, L., I $88 n .^{2}, 215 n .^{2}, 216 n$, $218 n ., 223 n .^{1}, 255 n^{1}, 266 n .^{1}, 268 n^{2}$

Fertility, ceremonies supposed to promote, 7 , 1 27, 1 28, 143, (1 53), I 54, 155, (162), 164, 168, 172, (174), $175,(176,179), 180,(181,185), 191$, (192), 195, 196, 199-202, 219,221 , $222,230,232,244,246,247,255$, $258,269,292,293,297,348-353$, $35^{8}, 364$

Festus, $264 n^{3}$

Feud, in the case of a runaway wife, 61 . See Blood-revenge

Fez, 3-6, 57, 60, 86, 92, 122, 264, 299, 312-315, 31 8,337 ; betrothal at, 20 sqq.; marriages between cousins at, 21, 23, 54 sq. ; dowry at, 21, 22, 66, $69,83,229$; mît $t^{8} \ddot{a}$ at, 83 ; ceremonies to which the bridegroom is subject at, I 31 sq9.; preparations for the wedding at, 133 sq9.; ceremonies in the bride's home at, $136 \mathrm{sqq}$.; fetching of the bride at, 165 sqq.; arrival and reception of the bride at, $193 \mathrm{sq}$.; meeting of bride and bridegroom and the morning after at, $225-230$, 260,269 ; continuation and end of the wedding at, 274 sq9.; later ceremonies and taboos at, 300, 301, 312 ; second marriages at, 329

Fiancé, the, Arabic name for, 20 ; avoids his father, 22, 48,313 ; gives presents to his betrothed, 24, 25, 31, 33, 34, $52,82,83,152,159,229,236,270$; receives from her presents of food or clothing, 24, 31, 34, 1 27, 143, 354 ; feasts in the home of, $25,31,48,88$ sq9.; dressed up as a bride, $25-27$, 323 ; seated on cushions, 25 ; milk and a date offered to, 25 ; silver coins stuck to his forehead, 25 ; presents given by his father or parents to those of his betrothed, $30,33,39,40,43$, $45,47,50,77-79,82$ sq.; money given by his father to be distributed among the women of her village, 33 ; blessings bestowed on, 48 ; kisses exchanged by his and the fiancée's father, 50; small presents given to his mother, 88, 94.

Fiancée, the, Arabic name for, 20 ; hides herself, 22 sq.; avoids her father, 22, 40,315 ; feasts in the home of, 23 , $27,28,33-35,3^{8-41}, 43,45,48,50$, 83 ; receives presents from her betrothed, 24, 25, 31, 33, 34, 52, 82, $83,152,159,229,236,270$; gives him presents of food or clothing, 24, 31, 34, 127, 143, 354; goes to the hot bath, 27 ; dressed up in a fine costume, 27 ; seated on cushions, 27 ; milk and a date offered to, 27 sq.; silver coins stuck to her forehead, 28 ; presents received by her parents from those of her betrothed, $3 \circ, 33,39,40$, $43,45,47,50,77-79,82$ sq.; grinding of wheat in her home with a silver coin underneath the handmill, 33 ( $c f$. 152 sq.) ; money given by the fiance's father to be distributed among the women of her village, 33 ; kisses exchanged by the fance's father and her own, $5^{\circ}$

Fight between the men of the bride's village and those of the bridegroom's party, 80

Fights, sham-, between the married men and the bachelors, 1 26, 1 28, I 3 1, 234, $269,285,286,346$; as means of purification, $128,224,245,261,268$, 325,327 ; between the bachelors and other young men on one side and the imsnein and women on the other, 204, 223, 346 ; between the bride's brother or uncle and the bridegroom, 210, 211 , 223,346 ; between the women and the bridegroom, $211,223,346$; between the bachelors and the unmarried women, $237,238,269,346$; between the bachelors and the women, 245 , $247,261,268,346$; between the 'arab and the male relatives of the bride and bridegroom, 279 sq.; between the older married men and the islan, comprising the younger married men as well as the bachelors, 285 . See Beating, Robbing 
Figs, 90, 170, 182, 1 83, 194, 206, 207, $209,213,216,217,231,233,237$, $249,281,287,303$

Fire, a means of purification, 122

Fireplace, 202, 208, 354

First-born child, 113, 119, 156, 161, 359

Fischer, A., 53 .1

Fish, scraped or cast on the bride's feet, $293 n^{1}, 299,353$; bought by the young husband, 299, 347 ; buried in the vegetable garden, 353

Fison, L., $317 n$.

Five, the number, a charm against the evil eye, $187 n^{2}$

Flags, 88-9 1, 93, 97, 108, 1 10, 1 26, 1 28, 1 30, 1 75, 177, 179, 210, 2 I 1, 230, $231,234,245,267,281,282,284$, 286, 309

Flour, 40, 43, 181, 183, 302, 303, 308, 322,336 ; smeared on the bridegroom's right hand or the kerchief round it, 103, 104, I I9; falling over the bride's uncovered right thigh, I 53 , 162 ; egg which is to be thrown at the mule ridden by the bride dipped into, 194, 195, $218,326,357$; offered to the bride, $197,207,214,216,327$; thrown by the bride over her head, 197, 207, 208, 217, 327; newly bought animals taken over, $219 n$. See Grinding

"Flour, the," 9 I

"—_, the day of the," 92

" - of the áhrir, the," I 53

Flower-pot with a sweet-scented plant carried in front of the bride, 184 , 188

Food supply, ceremonies supposed to increase the, 195, 201, 216, 217,219 , 296, 299, 358. See Good Year, Rain

Footprints, 150

"Forgotten day, the," 28 I

Forticth day after the arrival of the bride, ceremonies on the, 304-306, $325,351,354$

Forty days, 300, 309, 31 5, 341, 352

Fowl, the lacking signs of virginity substituted for by the blood of a, 229, $240,241,243,246,248,270$

Fox, $37 n$.

Fraenkel, I 2 I $n_{0}^{1}$

Frazer, J. G., I, $26 n .^{1}$ sq., $27 n ., 264$ $n .1,369 s q q$.

Friday, 28, 87

Fringe, lucky or unlucky, 204

Fruit. See Dried Fruit

Fțưâka, 57
Fumigation, 199, 235, 237, 244, 255, 296, 305,322

Funerals, honey at, 23 n., 320 ; ceremonies at, 37, 91, 319, 344

Garbîya, the, 3, 4, $126 n .^{1}$; cleaning and grinding of the wheat which is to be used for the wedding in, 88 ; fetching of the bride in, 168 ; arrival and reception of the bride in, 197

Gaudefroy-Demombynes, $17 n^{2}$, I $9 n$., $56 n ., 1$ I $8 n .^{\mathrm{J}}$ and $n . .^{3}$, I $20 n^{2}{ }^{2}$ sq., 124 $n .^{3}$, I $60 n^{1}$ sq., I $61 n^{3}, 192 n ., 264 n$. and $n .^{2}, 267 n .^{3}, 293 n .^{2}, 294 n ., 314 n$.

Gennep, A. van, $86 n^{1}, 345^{1}{ }^{1}, 365$

Germany, $120 n^{6}$, I 2 I $n_{*}^{1}, 123 n_{*}^{2}, 189$ $n .^{4}, 305 n$.

Gibraltar, the Straits of, 3

Girdle, Girdling. See Belt, Belting

Girl-friends of the bride, the, accompany her, 137, I 39-142, I44, 145, 155, $156,15^{8}, 169,184,197,208,346$, 363 ; make tours with her, 145, 155 sq.; paint themselves with henna, 1 56, I 57, 161, 327 sq.; with antimony, walnut root, and saffron, 295, 327 sq.; beat her brother, 157 ; fights between the bachelors and, $237,238,245,247$, $26 \mathrm{I}, 268,269,346$; give dates and silver coins to the bridegroom and his bachelor friends, $282 \mathrm{sq}$. See Women

Glawi, 3, 4, 341. See Igliwa

Goats, $78,282,308,309,336$

"Going out, the," 301

Goldmann, E., $257^{n .}{ }^{\mathrm{I}}, 25^{8} n$.

Goldziher, I., $53 n^{2}, 54 n ., 55 n^{1}$, $56 n^{1}$ sq., $122 n .^{3}$

Good luck, 7, 33, 92, 94, 107, 11 3, I 24, 1 39, 179, I 80, 185, 204, 207, 2 I $7,244,262,283,288,308,320$, $347,348,35^{8}, 361,364$

wishes, $3 \mathbf{1}, 43,95-98,100,104$, $125,138,202,227,269,347$. See Blessings, Congratulations

- year, ceremonies supposed to produce a, 1 1 3, 124, 196, 198, 209, 217 , 219, 298, 347, 348, 358. See Rain

Grain. See Barley, Corn, Durra, Wheat Granaries, 336, 340

Great Atlas, the, 2, 3, 5, 55, 66. See Amzmüz, Demnat, Glawi, Iglíwa, Infdủak

"Great Feast, the," 3r, I18. See Feasts

Greece, ancient, $23 n ., 26 n .^{1}, 124 n .^{2}$, $187 n .^{2}, 216$ n., 368. See Attica, Cos, Sparta

Greeks of Turkey, 255 n. 
"Greeting, the money of," $250,262 n .^{2}$ Grief, expressions of, 344

Grinding of corn, 336 ; of wheat in the fiancée's home, with a silver coin underneath the handmill, 33 ; in the fiancé's home, to be used for the wedding, 88 , 91-94, 319 sq. ; over the bride's uncovered right thigh, $153,162,353$

Grit, removed from the corn which is to be used for the wedding, 89-95, $214,320,324,347$

Ground, the, the bridegroom avoiding to sit on, 100, 102, 103, 105, 106, 115 , 123, I 30, 132, 227, 324; the bride avoiding to step on, $176,179,185$, $188,189,212,324$; water which must not touch, 352

Gruppe, O., $26 n .^{2}$

Guardian angels, 337

Guardianship, $15 \mathrm{sq}$. ; of property, $16 n .^{4}$ Guests, the presence of female, at the feast in the bride's home supposed to bring good luck to her, I 39, 364; milk or water offered to strangers who come as, 191

Gum-ammoniac, 105. See Index of Arabic Words, fâsoh

benjamin, $83,244,296$

Guns, firing off of, $31,41,44,45,48$, $50,78,88,89,91-96,108,109$, 111 $112,114,115,117,122,123,128$, $130,131,145,162,169,170,173$, $174,177-179,181-18_{3}, 185,188,195$, $197,204,210,211,214,218,280$, $281,287,322,327$; on the consummation of the marriage, 233, 236 , $237,240,242,245,249,251,253$, $266,267,322,331,344$

Guys, Henri, $17 n^{2}, 84 n ., 118 n .^{\mathrm{I}}$, $125 n ., 161 n .^{3}, 222 n .^{2}$

Has, 19 n., $120 n^{6}, 162$ n., 2 I $5 n^{1}$ sq., $262 n .^{1}$

Habt, the, 6, 57 n., $84 n^{\mathrm{I}}$, II $n .^{1}$, $168 n^{2}$

Haḍramaut, $186 n .^{1}, 188 n .^{2}$ and $n .^{5}$

Háha, 335

Hair, the bridegroom's, shaved off, 102, $106,120,127,130-133,321,324$; put inside a bundle of clothes, 127 , 230, 231, 324 ; the bride's, dishevelled, $148,169,172,247,261,264,291$, $321,328,331$; smeared with henna, $151,153,160,252,295,332$; one side of it plaited by the bridegroom, $237,247,248,26 \mathrm{r}, 355$; ceremony relating to the ribbon with which it is fastened, 247, 248, 261; arranged in the fashion of married women, $25^{2}$, $276 \mathrm{sq}$. ; the end of one of its plaits undone by the bridegroom, $261 n^{1}$, 276,325 ; the young wife's, opened and plaited, 305 ; smeared with henna, 306 ; the bridegroom's mother and the other women of his family going about with dishevelled, 291, 328

"Hair, the loosening of the," 252

Hanafis, 16,64

Handmill of the househiold, a runaway wife or other refugee taking hold of the, $60,63,339$

Hanoteau, A., $59 n^{2}, 76 n ., 77 n^{1}$, 368 sq9.

Hartland, E. S., 216 n., $257 n .2,35 \mathrm{I}$ $n^{2}$ sqq., $352 n_{0}^{2}, 353 n_{*}^{1}$

Hausas, $118 n .^{1}$, $123 n .^{2}, 160 n .^{1}$

Headgear or headgears, 82, 200, 223 ; the bride's, 148, 172, 2 I 1, 235, 256, 277

Heape, W., 373

Hedgehog, $37 n$.

Henna, 31, 34, 40, 52, 78, 83, 150,178 , 190, 281, 310, 324; the bridegroon painted with, 90, 95, 97-102, 105, 107-122, 124, 125, 171, 199, 238, $242,248,260,321$ sq. ; used by the best-man and other bachelors, 98, 113 , r2o, 327, 360; silver coin painted with, 107, 125 ; baraka attributed to, I 8 ; used at religious feasts, 118 ; the bride painted with, $136,137,141$, $142,144-151,153-158,160-164$, $175,178,185,188,242,252,295$, $320-322,333,353,355$; sprinkled by her on some young men who are thereby appointed to be her imsnein, 151 ; used by the women who take part in the wedding, 153, 1 57, 161, 327 sq.; by the bride's girl-friends, 156,157 , 161,327 sq.; the bride sprinkled with a mixture of water and, 177, 190,326 ; smeared on the saddle in which she has been riding, 210,219 , 327 ; the bride received with, 214 , 217,326 ; applied to the ribbon with which her hair is fastened, 247, 261 ; used by the young wife and other women, 303 ; sprinkled on the domestic animals, 303,362 ; the young wife's mother painted with, 303 ; smeared on the young wife by her mother, 306

"Henna, the great," I01, 109, I15, I19, I $30,260,355$

"L, the little," 101, 105, I I9

Hiáina, the, $3,86,218 n^{2}, 261,263$, 
312, 318, 336, 337, $339 n .^{1}, 340 n .^{2}$; betrothal in, 34 sq.; réswa in, 35 , 79,303 ; dowry in, 70, 71, 102, 260, 303 ; mákla in, 77 ; cleaning and grinding of the wheat which is to be used for the wedding in, $9 \mathrm{I}$; the bridegroom painted with henna in, 102 ; ceremonies in the bridegroom's home previous to the wedding in, 102-105, 260; the bride's hennaceremony in, I $47 \mathrm{sq.;} \mathrm{fetching} \mathrm{of} \mathrm{the}$ bride in, $172 \mathrm{sq}$.; arrival and reception of the bride in, $19^{6}$ sq.; meeting of bride and bridegroom and the morning after in, 236 sqq.; continuation and end of the wedding in, 282, 290, 293, 294,296 sq.; later ceremonies and taboos in, 302-306, 312

Hidāyah, $30 n$.

Hlot, the, 6, $57 \mathrm{n.}$, I I $7 \mathrm{n.}^{1}$, I $18 \mathrm{n.}^{3}$, $168 n^{2}$; mákla in, 77

Holiness, the nature of, I I 9, 265, 343, 360 ; protected from pollution, $334^{-}$ 337, 339 sqq. See Index of Arabic Words, baraka

Honey, 23, 29, I I 4, I 82, 201, 25 I, 278, $320,337,340$

Horses, 337, 340. See Mare, Stallion

Hose, Charles, 374 sqq.

Hospitality, in connection with the institution of brotherhood, 58

Höst, G., i $8 n^{3}$

Houdas, O., $85 n^{1},{ }^{1} 5^{6} n$. $^{1}$

Household duties, beginning of the young wife's, 295 sqq.

Howitt, A. W., $317 n$.

Hughes, T. P., $255 n .^{1}, 359 n .^{7}$

Huntsmen, 38, г 09 , г 28 , г 30,169 , г 70 , $28 \mathrm{I}$

Hurgronje, Snouck, $17 n^{2}, 18 n^{2} s q .$, $22 n .^{1}, 74 n .^{2}, 160 n *^{1}, 164 n *^{1}, 268 n .^{1}$

Husband's death, dowry in the case of the, $65-68,70-73,76$; practices supposed to cause the, $171,172,189$, $353 \mathrm{sq}$.

Hutchinson, H. N., $220 n^{2}$

Hymeneal blood, medicinal virtue ascribed to, $159,265,362$; substituted for by the blood of a fowl or pigeon, 229, 240, 241, 243, 246, $248,270,370$; regarded as a seat of danger, $265,266,334$. See Virginity

Igliwa, 3, 4, 86, $218 n^{2}, 340 n^{2}$; brotherhood between the Infdurak and, 57 ; dowry among the, $67 \mathrm{sq}$. ; cleaning of the corn which is to be used for the wedding among the, 94; the bridegroom painted with henna among the, 116 sq. ; ceremonies in the bride's home among the, 157 ; fetching of the bride among the, 185 ; arrival and reception of the bride among the, 213 sq.; meeting of the bride and bridegroom and the morning after among the, 253 sq.; continuation and end of the wedding among the, 289 ; later ceremonies and taboos among the, 310. See Afra, Ait Árrba, Ait Ugंdat, Arg, Glawi, Isirs, Táfga

Incantation, against the devil, 98, 1 22, 323 ; at curing a patient, 261

Incense, $83,104,105,133,199,235$, $237,244,255,296,305,322$

Incest, the prohibition of, 2I2, 2 I3, 370 sqg.

India, ancient, $19 n$, I $20 n^{6}, 148 n$. , $162 n ., \quad$ I $63 n^{4}$, , 2 I $5 n .^{1}$ sq., 2 I $6 n$., $219 n^{\mathrm{I}}, 255 n_{0}{ }^{1}, 262 n^{1}{ }^{1}$; modern, I $23 n .^{2}$, I62 $n_{\text {., }} 2$ I $5 n_{0}^{1}, 2$ I $6 n$., $25^{8} n .^{3}, 3^{6}$; ; Muhammedans of, $17 n .^{2}$, 20 n., 3 I $n ., 84 n$. , I I $8 n^{\mathrm{I}}, 123 n^{3}$, I $60 n^{1}$, I 6 I $n .^{2}$ sq., I $88 n .^{3}, 260 n^{1}$

Indo-European peoples, I0, I62 n., I 63 $n^{4}, 2$ I $5 n_{\bullet}^{1}, 2$ I $7 n$.

Infḍ̆ak, 57

Inheritance, the right of, denied to a woman who leaves her village, 56

Inn, earth from the entrance of a public, 28

"Inoculation," Mr. Crawley's theory of, $26 \mathrm{sq}$.

Invitations to weddings, I I $\circ$ s. ; must be accepted, 85,364

Isirs, 67

Islam, 10, $59 n^{\mathbf{1}}, 65,77,33^{8}, 359$. See Muhammedan Law

Isle of Man, the, $257 n^{2}$

Jaffa, I $62 n .^{3}$, I $86 n .^{1}$, I $89 n^{3}$

Jaffur Shurreef, I $7 n .^{2}, 123 n .^{3}$, I $61 n^{3}$, $260 n^{1}$

Jansen, H., $22 n^{2}$, I 2 I $n_{*}^{1}, 2$ I $6 n$. , $222 n$.

Jaussen, A., $18 n^{3}, 56 n ., 59 n^{1}, 75 n$. , $\mathrm{I} 64 n, \mathrm{I} 8 \mathrm{~S} n_{\circ}{ }^{2}$ and $n_{0^{5}}, 222 n$. and $n .{ }^{\mathrm{I}}$, $224 n ., 29$ I $n^{2}$

Jbâla, 2-4, 7 n., 1 I 8 n. ${ }^{3}, 339$. See Andjra, Beni Ulîd, Habț, Jbel lä̀-Hbib, Tsūl

Jbel lä-Hibíb, 32, 88

Jealousy, overruled by the desire for offspring, $328 n .^{8}$

Jevons, F. B., $220 n^{2}$

Jews, ancient, $163 n .^{2}, 187 n .^{2}, 217 n$, $289 n$.; of Egypt, in the Middle Ages, 
$26 n^{1}$; modern, $121 n_{*}^{1}, 162 n$, 216 sq. $n_{.}$; of Morocco, I $21 n_{.}$, I 5 I n., 215 n.1, 216 n., 222 n., 368

Joy, expressions of, 267,344

Judea, $75 n$.

Judge, guardianship of the, 16 ; earth from the entrance of the room where sentences are pronounced by the, 28

Kabbabish, 2 I $5 n .^{1}$

Kasteren, van, $217 n$.

Keith, A., 367

Kerak, $222 n$. 1

"Kerchief, the," 50

Kettle, $37 n$.

Kicking of the bride by the bridegroom, $242,256,35^{6}$

Kidnapping of women, $61,80 \mathrm{sq}$.

Kissing, 48, 50, 138 , I 39, 194, 196, $207,208,211,230,233,235,258$, $280,285,288,291,292,302-304$, $307-310,314,315,317,357$

Kitāb al-ağānt, $53 n *^{2}, 54 n$. $^{1}$

Klein, F. A., $18 n^{2},{ }^{2} 6 n_{., 7} 5 n_{.,} 82 n .^{3}$, $120 n .^{3}, 160 n .^{1}, 161 n^{2}$ sq., $188 n .^{1}$

Klunzinger, C. B., 56 n., $120 n^{2}$, $123 n^{1}, 160 n_{*}^{1}, 161 n^{3}$

Knots, in the cord of the bride's drawers, 232, 264 sq.; as impediments, 264

Koran, the, recitations from, 198,199 , $232,255,266,323,335$

Kordofan-Darfur border, the, 2 I $5 n^{1}$

Kulsúm Naneh, 151 n.1

Lälla Jẹbrîn, 200, 349

Lamb hurled by the bride over the bridegroom's tent, 204, 221,36 I

Lane, E. W., $17 n .{ }^{2}, 20 n ., 56 n ., 74 n^{2}$, $82 n_{0}^{3}, 84 n ., 85 n_{0}^{1}, 86 n^{2}, 87 n^{1}$, $120 n^{2}$ and $n^{4}, 123 n 0^{3}, 160 n_{0}^{1}$, $161 n^{1}$ sqg., $164 n^{1}, 184 n_{\text {., }} 187 n^{1}$, $188 n 0^{3}$ sq9., $255 n .^{4}, 263 n 0^{3}, 267 n .^{1}$, $268 n 0^{2}, 338 n 0^{1}, 359 n 6^{6}$

Lane-Poole, S., $338 n$.

Lang, Andrew, 374

Language, 4, I i sq9.

Lawsonia inermis. See Henna

Layard, A. H., $25 n ., 339 n .^{1}$

Lees, G. Robinson, $18 n_{*}^{2}, 56 n_{4}, 289 n$.

Leg-rings, I 54

Lennep. See Van-Lennep

Leo Africanus, $6 n^{1}, 8_{3} n_{.}, 167,186 n^{1}$, 230, 299, 353

Lerchundi, J., $143 n^{1}, 168 n_{0}^{2}$

Letourneux, A., 59 n. ${ }^{2}, 76$ n., 77 n.1, 368 sqq.

Levirate, 59 sq.

Libyan Desert, the, $188 n^{2}$ and $n .^{5}$
Light, spirits terrified by, 122

Liver, the, of the sheep slaughtered at "the great henna" of the bridegroom, 101, 259, 260, 355 ; of the bullock, which he presents to his bachelor friends, 126,361

Löbel, D. Th., $87 n^{1}$, I60 $n^{1}$, $161 n^{3}$, $255 n .^{1}, 263 n .^{3}$

Looking back, prohibition of, 172,189 , $231,250,255,295,324,353$ sq.

-glasses, $83,176,178$

"Loosening of the belt, the," 159

"- of the hair, the," 252

L-Qșar 1-Kbir. See Alcazar

Luck. See Good Luck

Lynch, W. F., $162 n_{*}^{3},{ }_{1} 86 n^{1}$, $189 n^{3}$

M'Dougall, William, 374 sqq.

M'Lennan, J. F., $257 n^{2}$

Mădabā, $222 n$. $^{1}$

Malay Peninsula, the, Muhammedans of, $118 n^{1}$ and $n^{3}, 120 n^{4}, 121$ sq. $n .^{3}, 160 n^{1}, 161 n^{2}$

Mălikıs, 1 5-18, 64, 86

Malinowski, B., 375

Mannhardt, W., $120 n^{6}, 196 n ., 216 n$.

Marçais, W., $22 n^{1}, 85 n_{*}^{1}, 168 n_{*}^{2}, 256$ $n$. $^{1}$

Mare, the bride taken to the bridegroom's place on a, 171, 172, 175 . 178-180, 182, 184-186, 191, 348 sq. ; baraka ascribed to a, 205. See Animal ridden by the bride

Marindin, G. E., $264 n^{3}{ }^{3}$

Maronites, $216 n ., 218 n ., 222 n$.

Marquardt, J., $264 n$. $^{3}$

Marrakesh, 5, 252

Marriage, by purchase, 19, 65, 73 sq9.; with a deceased brother's widow, 59 sq.; with a runaway wife, 6o sqq.; by capture, $80,81,163 n^{4}, 220 n^{2}$, $257 n_{*}^{2}, 316 s q$. $n$.; time for the celebration of a, $86.88,320$; ceremonies supposed to promote unmarried people's, 145, 153, 165, 168, 196, $291,292,362$ sq.; regarded as a religious duty, 359. See Consent, Consummation of the Marriage, Contract of Marriage, Defloration of the Bride, Divorce, Dowry

- tie, practices (presumably) supposed to strengthen the, $101,102,127,136$, 141-147, 149, 150, 157, 158, 161 , 164,169 , 170, 190, 202, 208, 222, $226,227,231,235-237,244,247$, 249-251, 253, 258-261, 305, 349, 353 sq9. 
Marriages between cousins, 21, 23, 49, 53 sqq.; disguises at, $25-27$, I 52 , $153,163,165,174,187,188,198$, 1 99, 284; early, 34, 3j, 44, 48 sq.; contracted inside the same village, 56 ; between members of different villages, $5^{6}$; between members of different tribes, 56 sq.; between Berber- and Arabic-speaking people, $5^{6}$ sq. ; prohibited between certain tribes, subdivisions of tribes, or villages, 57 sqq.; second, 328 sqq.; displeasing to the devil, 344. See Endogamy, Exogamy, Incest

Marshall, F. H. A., 373

Masai, $26 n .^{1}$

Mat, a father obliged to provide his daughter with a, 75

Match-makers, professional female, 20

Matthes, B. F., $26 n$. I $^{\mathrm{I}}$

Mazagan, 4

Mazouna, $294 n$.

Meakin, Budgett, 6 n.8, 96 n., 99 n., $114 n_{\text {., }} 117 n^{2}, 143 n .1,152 n .^{2}, 166$ $n$., $193 n$.

Meal or meals, served in the fiancée's home, $23,34,35,38-40,43,45,46$, $48,50,83$; in the fiance's home, 31 , 48,88 sqq.; in the bridegroom's home, 36, 88-94, 96, 99, 102, I06, $109,125,130,131,133,134,173$, 182,195 , I 96, 198, 202-204, 206, 208, $211,212,227,230,234,235$, $240-242,245,247,251,274,275$, $277-281,284,289,292$; bride and bridegroom having a common, 101, $227,231,237,244,250,251,253$, $25^{8-260}, 275,276,281,355,362$; given to the bridegroom and his party, $108,111,114,282,284$ sq. ; in the bride's home, 140, I42-144, 146, 149, 1 54-1 58, I69, 172-174, 178, 181 , $183,184,186,228,329$; given to the bride and her party in the houses they visit, 145, I 56 ; given by the bride's mother, $183,204,236,238$, $239,243,245-247,249,268,269$, 292, 299; partaken of by the bride and the imsnein or amsnäi, 240, 241, 273,288 ; by the bridegroom and the imsnein, 24I ; a compact of friendship sealed by a common, 259, 364 sq.; served with food from other households in the bridegroom's village than his own, 289; served in the young couple's home, 301,305 ; in the young wife's parents' home, 301, 303; given to the young husband by his parents-in-law, 304; the social importance of, at weddings, $364 \mathrm{sq}$.

Mecca, $17 n^{2}$, $18 n_{0}^{2}$ sq., $5^{6} n_{0}, 74 n^{2}$, $160 n^{1}, 164 n^{1}, 268 \cdots{ }^{1}$

Mediators at a betrothal, 19-21, 29, 32, $35,37-39,42,43,45-47$, 50 sqq.

Medina, I $7 n .^{2}, 74 n .^{2}$

Mediterranean origin of the Berbers, ro, 367

Meer Hassan Ali, Mrs., 20 n., 31 n., $118 n^{1}, 160 n_{0}^{1}$, I 6 I $n_{*}^{2}$ sq., $188 n_{0}^{3}$

Meeting of the bride and bridegroom and the morning after, $15^{8-160,171,}$ 225 sqq.

Menouillard, I6 $1 n^{3}, 3$ I $3 n .^{2}$

Menstruation, 336, 341 sq.

Mercier, E., $82 n^{3}{ }^{3}$

Michaux-Bellaire, E., $6 n .^{3}$ and $n^{6} s q$, $20 n_{.,}, 57$ n., $77 n .^{2}, 82 n .^{3}, 84 n .^{1}$, I $17 n .^{1}$ sq., I $8 n^{3}$, I $25 n$., I $68 n^{2}$

Midsummer, $35^{1}$

Milk, 7, 24, 194, 214, 218, 326, 347, 357 ; offered to the fiancé, 25 ; to guests, 25, 28, I 39, 194, 226, 364; to the fiancée, 27 sq.; drunk by the bride's mother, 139 ; offered to or sprinkled on the bride, $145,164,170-$ $174,177,180,182,183,185,190$, 194, 203, 207, $210,212-216,218$, $326,357,361$; offered to strangers who come as guests, 191 ; drunk by the bridegroom's mother, 194 ; by the bridegroom, I94; sprinkled by the bride on the people, 207, 361 ; newly bought animal taken over a bowl of, $218 \mathrm{sq} . n^{2}$; the young wife's feet washed with, 302 sq. ; offered to the young husband, 304 ; to the young couple, 308

Mill, earth from the entrance of a, $2 S$. See Handmill

Milliot, L., $15 n .^{1}, 16 n .^{4}, n .^{3}$, and $n_{0^{5}}$

"Ministers." See Index of Arabic Words, waะâra, wi̊zâra, wứzra; Index of Berber Words, iuæîrẹ̆n

\section{Mint, 24}

Mishkāt, $359 n^{7}$

Moab, I $8 n^{3}, 56$ n., $59 n .^{1}, 75 n$., I $88 n .^{2}$ and $n .5,222 n ., 224 n$., $291 n .^{2}$

Mock-bride, $33^{\circ}$

Mogador, 2, 5, 252

Moharram, marriages avoided in, 86

Money, fixed on the fiancé's forehead, 25; on the fiancée's forehead, 28 ; sent by the fiancé and put underneath a handmill, $33,15^{2}$ sq.; given by his father to be distributed among the women of the fiancée's village, 33 ; by 
the fiancé and his friends to be spent on the bride's trousseau, 34 ; put in an empty dish or on an empty tray, 34 , 239, 241, 249, 287; paid to other members of the girl's family than her father, $43,79-82,169,186,345$; to the husband of a runaway wife, 60 sq9.; worn by or offered to the bride, 72 , $73,146,147,150,157,162-164$, 174, 191, 207, 250, 258, 262 n. $322,347,357$; presented to the fiance's mother, 88; ceremonial giving of, ('grâma), in the bridegroom's home, 100, 103-105, 107, 109, III-II3, I16, 124, 125, 132, 226, 227, 234, $254,269,347$; in the bride's home, $138,139,142,146,148,149,155$, I64, 347 ; given to musicians, I05, $142,227,234,274,276$; the bestman buying his post with, 106; painted with henna, 107, 125 ; given to the bridegroom and his party, 108, 109, 281 sqq.; given by the bridegroom when he is painted with henna, III ; by the bridegroom to the bride immediately before or after the connection, I I 3, I $59,237,239,241$, $242,244,248,251,253,262,263$, 325 ; after he has coiffed her, 248, 261,325 ; when he meets her, 250 , $25^{8}, 262 n^{2}$; after he has girdled her, 294, 325 ; on other occasions, $148,152,155$; given by the bride to the person who spreads his cloak or hâyẹk in front of her, $175,176,179$, i $9 \mathrm{I}, 361$; claimed by the bride's family if she has to cross a river, 185 , 186,345 ; given by the bridegroom to scribes, I 99 ; by the bride to the man who lifts her into the bridegroom's tent, 207 ; by the bridegroom to the women guests at the wedding, 212 ; walked over by a newly bought animal, $218 n 0^{2}$; put on the bride's drawers, 228, 269; given by the bridegroom to the bride's hadday'n, 233 ; given to the bride's mother in return for a meal, $239,243,249$; put by the bridegroom on the bride's hair when he has undone one of her plaits, $261{ }^{1}, 276,325$; given to doctors, $26 \mathrm{~s}$ s.; to the bride by the women of the bridegroom's village, 280 ; by her mother-in-law, 281 ; by visitors, 285 ; given by the bride and her girl-friends to the bridegroom and his bachelor friends, 282 sq.; to the bridegroom by his sisters and female cousins or friends, $287 \mathrm{sq}$; by the bridegroom to the donors, $287 \mathrm{sq}$.; left by the young wife at a shrine, 296 ; given to her by relatives, 303 ; by her father, 307 sq.; by the young husband to his mother-in-law, 303, 304, 308. See Bride-price, Coin, Dowry

"Money of the drawers, the," 251, 262

"—— of greeting, the," $250,262 n 0^{2}$

" - of the morning, the," 242

"Moors," the meaning of the word, 3

Mornand, F., I62 $n^{3}, 189 n^{3}$

"Morning, the," 159,248

"—_, the day of the," 274

" _. , the dish of the," 236

"—-, the money of the," 242

"__, the woman's," 249

"—_ of the bride, the," 240

"_- salutation, the," of the bachelors, 202

Mosque, the chemise of a girl hoisted at the minaret of a, 28 ; earth from the entrance of $a, 28$; the bride taken round the, in the bridegroom's village, 199, 200, 203, 208, 21 5, 326, 331, 332,349 ; sexual acts prohibited in a, 334 sq.; unclean individuals prohibited from entering a, 335, 341

\section{Mosul, $25 n$.}

Mother, the marriage of a girl arranged by her, 29 sq.; a young man asking advice of his, 32 ; speaking about his love to his, 36 ; hearing about his future marriage from his, 37 ; the result of a proposal influenced by the girl's, 37 sq.; money or a garment given to the girl's, 43,79 sq.; choosing a wife for her son, 45 sq.; small presents given to the fiance's, 88, 94; the young couple visited by the wife's, 291, 292, 303 sq. ; presents given by the young wife to her, $301,302,307$, sqg.; the young wife's feet washed with milk by her, 302 sq.; henna smeared on the young wife's, $3 \circ 3$; the young wife painted with henna, antimony, walnut root, and ochre by her, 306 ; the young couple received with milk by the wife's, 308 . See Bride's mother, Bridegroom's mother, Parents

Motion, a means of purification, 121

Mouette, G., $217 n$.

Mouliéras, A., 7 n., 49, 57 n.1, $118 n^{3}$, 272

Mount Sinai, $74 n .^{2}$, 16 6 sq. $n .^{3}, 164 n$., I $88 n .^{1}, 215 n .^{x}, 265 n{ }^{2}$ sq., $291 n^{2}$

Mourning observances, 344 
Muelinen, E. von, $75 n$.

Muhammed, the name, 113 , 1 19, 359

Muhammedan law, concerning the betrothal and marriage contract, I5 sqq.; concerning the dowry, 64 sqq.; concerning the celebration of the marriage, 85 sq.

Muhammedans outside Morocco, Io, I $7 n^{3}$, I $8 n^{2}$ sq., I 9 ., 20, 2 I $n$., $22 n .1,23 n ., 25 n ., 3$ I $n ., 55$ sq., 59, 74 sq. n. ${ }^{2}, 76$ sq., 82 n. ${ }^{3}, 83$ sq. n., $86 n .^{2}, 87 n .{ }^{1}$ sq., I $\mathrm{I} 8 n .^{1}$ and $n .{ }^{3}$, I 20 $n .^{2-4}$ and $n .^{6}$, 121 I.$^{1}$ and $n .^{3}, 122$, $123 n_{0}^{1}$ and $n_{0^{3}}$, I $24 n_{0}{ }^{3}$, I $25 n$., I 5 I $n .$, I 60, I 6 I $n .^{1}$ sqq., I $62 n$. and $n .^{2}$ sq., $163 n . .^{2}$ sqq., $164 n$. and $n .{ }^{1}, 184 n$, I 86 n. ${ }^{1}$ sq., I $87 \quad n .^{1}$, I 87 sq. $n .^{3}$, I $88 n .^{1}$ sqq., $189 n .^{3}$, I $92 n ., 2$ I $5 n .^{1}$ sq., 216 sq. n., $217 n .1,218 n$. and $n_{0}^{1}$, $219 n .1,221$ n., 221 sq. $n .^{2}, 222 n .^{1}$ sqq., $223 n 0^{1}, 223$ sq. $n^{2}, 255 n^{1}$ and $n^{3}$ sq., $256 n^{1}$ sq., $258 \quad n .^{2}, 260 n^{1}$, $26_{3} n .^{1}, 26_{3}$ sq. $n .^{3}, 26_{4} n .^{2}, 26_{5} n .^{2}$ sq., $266 n .^{1}$ sq., $267 n .^{1}$ and $n .^{3}, 268$ $n^{1}$ sq., 289 n., 291 n. ${ }^{1}$ sq., 293 n. ${ }^{2}$, 294 n., $3 \times 3$ sq. n.2, 315 n., 338, $339 n . \mathrm{I}, 359,367$ sqq.

Mûläi 'Abdsslam, 129

\section{Idris, 23}

Mule, the bride taken to the bridegroom's place on a, 170, 182-185, 191; a woman not allowed to ride a, 340 . See Animal ridden by the bride

Music, Musicians, 25, 27, 78, 91, 92, 94-99, 1 02, 1 05, I 1 7, I 2 2, I 25-1 28, I $30,131,133,137-143,145,148$, $162,169,170,173,178,179,182$, $183,188,195,202,206-208,218$, 227, 234, 240, 274-276, 278, 280, $281,283,287,294,297,314,322,344$ Myrtle twigs, I 32

Needles, 37 n., 1 50, 162, 237, 256, 290, 322

Negresses. See Black Woman

Negro type, 367

Negroes, carrying the bridal box, I 68 . See Black Man

"Neighbours, the," I 42

Nestorians of Syria, $\mathrm{I}_{4} n$.

Net made of rope, $246,247,349$

"Night." See "Evening"

"

Nilsson, M. P:n, $26 n$. $^{2}$

Notaries, 52, 67, 69, 70, 229

Numbers, magical. See Five, Seven, Three

-, unlucky, 7 I
Ochre, $83,153,193,28_{3}, 295,306$

Ockley, S., $20 n$.

Offspring, desire for, $44,49,328$; ceremonies supposed to promote the birth of male, I 54, I 55, I 68, I72, (174I 76, 179, 181, 1 85), I 91 , (1 92), 200202, 22I, 222, 292, 293, 297, 348 sqq.; of good, $244,255,350$; practice supposed to influence the looks of the, $159,269,270,350$; practices intended to prevent the production of sickly, 265, 266, 281, 350. See Fertility

Oil, 30, 50, 67, 78, 201, 352

Oleander, I 68, 322

Omens, 32, 92, 1 37, 172, 175, 180, 1 92, $200,205,208,209,222,247,248$, 252, 256, 257, 299, 319-321, 351, $35^{2}, 35^{6}$

Ominous numbers, 7 I words, 37,3 I 9

"Opening, the," 262

"—_ of the belt," I 59, 237, 239, 241, $244,253,262$ sq.

Ouargla, 160 $n_{0}^{1}$, I 6 I $n_{0^{1}}, 265 n_{*}^{2}, 289 n$. Oven, earth from the entrance of a public, 28

Palestine, I7 $n .^{2}$, I $8 n^{2}, 2$ I $n ., 56 n ., 75$ $n ., 82 n .^{3}$, I $20 n^{2}$ sq., I 25 n., I $60 n^{1}$, I 6 I $n .^{2}$ sq., I $62 n .^{3}$, I $86 n .^{1}$ sq., I $87 n .^{1}$ sq., $188 n .^{1}, n .^{2}$, and $n .^{5}, 189 n^{3}, 215$ $n^{2}, 217 n 0^{1}, 2$ I $9 .^{1}, 221$ sq. $n .^{2}, 268$ $n .^{2}, 289$ n., 29 I $n .^{1}$ See Jaffa, Jews (ancient), Judea, Kerak, Mādabā, Moab

Palmer, E. H., I6r sq. . $^{3}$, I64n.

Palmetto leaves, 298,348

Pan, earthenware, $37 n$.

Parents, arranging their children's marriage, $20-24,29,34,41,42,45,46$, $4^{8}$ sqq.; shyness of, $22,29,36,40$, $42,46,48,117,249,252,253,271$, 288,313 sqq.; presents given by the young man's father or parents to his fiancée's, 30, 33, 39, 40, 43, 45, 47, $50,77-79,82,83,146$; respect for, 36 ; the young husband kissing the heads or hands of his, $48,314 \mathrm{sq}$.; the young wife visiting her, 300-304, 306 sqq.; receiving presents from them, 301-303, 307 sqq.; giving presents to them, 302, 306-310, 362 ; kissing their heads, 302, 303, 307 , 308,310 ; removing and kissing their slippers, 303. See Bride's father, Bride's mother, Bridegroom's father, Bridegroom's mother, Father, Mother 
Parents-in-law, the young husband paying a visit to his, 291, 300-302, 304 306 sqq.; giving them presents of food, 291, 301, 302, 306 sqq.; kissing one or both of them on the head, 291, 302-304, 307 sq9.; shy of them, 304, 307,309 sqq.; avoidance of, 307 , 310 sqq.; terms applied to, 312, 317 sq.; the young wife kissing the heads of her, 317

Payments. See Money

Pearls, 133

Peganum Harmala. See Index of Arabic Words, hármel

Persia, $56 n .^{2}, 151$ I $n ., 221 n^{1}$, $255 n .^{3}$

Perthshire, $215 n$. $^{1}$

Pigeon, the lacking signs of virginity substituted for by the blood of a, 229, $270 n ., 37^{\circ}$

Pilgrimage, 86

Pillow, a father obliged to provide his daughter with a, 75

Pistol, 79 ; carried by the bridegroom, $112,123,248,255,290,322$

Ploughing, days for the beginning of the autumn, 87

Ploughman, 335 sq.

Plutarch, $26 n .^{1}, 87 n .^{4}, 187 n .^{2}, 220 n .^{2}$, $252 n$., $261 n$. $^{2}$

Pollution. See Sexual Uncleanness

Polygamy, 328

Pomegranates, 182

Porridge, 242, 267, 327. See Index of Arabic Words, tštša; Index of Berber Words, áhrir

"Pouring," 136

“__, the day of," 136

l'owder, spirits afraid of, 123 -play. See Guns

Prayer, $114,115,130,230-232,234$, $244,250,251,255,266,280,323$, $335,340 n .^{2}, 34 \mathrm{I}, 35^{\circ}$

"Prayer of the bride, the," 205

l'reller, L., $221 n$.

Present or presents, given by the fiancé to his betrothed, $24,25,31,33,34$, $39,40,52,82,83,152,159,229$, 236,270 ; by the fiancée to her betrothed, 24, 31, 34, 127, 143, 354; by the young man's parents to those of the girl in connection with a betrothal, $3 \circ, 33,39,4 \circ, 43,45-47,5^{\circ}$, $77-79,82,83,146$; to other members of her family, 35,79 sq9.; to the girl by her father, 83 sq.; to the fiance"s mother by women of her village, 88 , 94 ; to the bridegroom's father by guests, IOI; to the bridegroom and his party, 108, 109, $28 \mathrm{I}$ sqq.; to the bride by guests and relatives, 139 sq.; to the young wife by her husband, 143,286 ; to the bride by the bridegroom, $155^{2-1} 54,156,157,175,178$, $261,276,279,285$; to the bridegroom by the bride, $226,260,261$, 354 ; to the musicians, 234 sq.; to the young couple or the young wife by her parents, 277, 278, 301, 302, $304,307 \mathrm{sqg}$.; to the bridegroom and his bachelor-friends by the bride and her girl-friends, 282 sq.; to the bride-groom by his sisters and female cousins or friencis, 287 sq.; by the young husband to his parents-in-law, 291, $301,302,304,307$ sq9.; by the young wife to her parents, $301,302,307$ sq9.; to the young wife by the people of her own village, 302 ; by relatives, $3 \circ 3$; the social importance of the giving of, 364. See Money

"Present, the," 30, 70, 77 sq.

"__ of the bride, the," 241

Pretium virginitatis, 263

Prophylactic ceremonies, I 18 sqg., I 28 sq., 160 sqq., 187 sqq., 214 sqq., 254 sqq., 289 sqq., 294 sqq., 304 sqq., 321 sqq., 334, 344 sqq., 357 sq.

Proposal, 17, 19, 21, 22, 28-30, 32, 35, 37 sqq.; refused, $28,32,33,45,319$

Purchase, marriage by, $19,65,73$ sqq.

Purification, ceremonies of, 118 sqq., 128 sq., 160 sqq., 190 sq., 214 sqq., 254 sqq., 295 sqq., 304 sqq., 321 sqq., 334, 344 sqq., 357 sq., 362

Quivering noise maje by women, 22, 25, $33,41,44,45,48,50,67,78,80,89$, I03, 104, 107, 109, I I2, I 22, 129 , $133,136,138,140,148,155,162$, I 73, 174, 182, 183, 188, 194, 195, $197,218,225,226,228,233,236$, $237,240,242,243,245,249,253$, $267,269,294,296,297,322,344$

\section{Rabies, 337}

Raḥámna, 6, I17 $n^{1}, 118 n_{0^{3}}$

Rain, ceremony supposed to prevent, 89,348 ; ceremonies supposed to ensure, $90,93,94,180,190,198$, $203,209,216,347,348,360$

Raisins, I 50, 171, 182, 1 83, 194, 204. $209,212,216,217,231,233,249$, $250,281,287$

Ramad̦ann, 341

Reapers, 336

Red, use of, $r 48,284,343$; raisins, 204 
Refugee, inviolability of a, in connection with the institution of brotherhood, $57 \mathrm{sq.;}$ taking hold of the handmill of the household, 60,63, 339. See Asylums

Reinach, S., $26 n .^{2}, 217 n$.

Reinsberg-Düringsfeld, O. von, 2 I $5 n .^{1}$

Remarriages, 328 sqq.

"Reverent visit of the bride, the," 302

Ribbon with which the bride's hair is fastened, 247, 248, 26 I

Rice, casting of, at weddings, 343

"Ride of the bridegroom, the," 129

Rif, the, 2, 3, 7 n., 53, 56. See Ait Wäryâgäl, Ruâfa

Ring, silver, 286

Rites d'agrégation, 365 de séparation, 365

River, crossed by the bride, 185,190 , 326,345

Robberies, sham, at weddings, 200, 204, $223,233,234,269,286,325,346$

Robert, G., $160 n .^{1}$, I6 I $n .^{3}$

Rome, ancient, $87 n \cdot{ }^{4}, I_{3} n_{*}{ }^{2}$ and $n \cdot{ }^{4}$, I $87 n_{0^{2}}{ }^{2}, 2$ I $5 n^{2}, 2$ I $9 n^{1}, 220$ sq. $n .^{2}$, $222 n ., 252$ n., $261 n^{2}, 264 n .^{3}$

"Room of the rest, the," I 40

Rossbach, A., I $87 n_{*}^{2}, 2$ I $5 n^{2}, 2$ I $9 n^{1}$, $220 n^{2}, 222 n$.

Ruâfa, 2 sq. See Ait Wäryâgäl, RIf

Runaway wives, 60-63, 319

Russell, A. D., 15, $16 n .^{4}, 64^{n .}{ }^{1}, 66 n .^{1}$ sq., $85 n^{1}$

Russia, $3^{69}$

Rwâdi, r-, 34 I

Sacrifice, 60, 6I, 78, I41, 213,296 ; made to bring about a betrothment, $35,38,42,45,46,5$ I, 319; made when a strange woman spends a night in a house, $262 \mathrm{sq}$.; at the belting of the bride, 294. 325

"Sacrifice, the day of the," 78, I 41

Sacrificial victims, $201 n$.

Saddle, as an instrument of $l \dot{a} a r, 61$; the bridegroom seated on a, 105,115 , 123 ; the bride seated on a, I 51,356 ; avoidance of an empty, 172, 180,182 , $192,320 \mathrm{sq}$. ( $c f$. , on the other hand, 181) ; smeared with henna or blood, $210,219,327$

Saffron, I 52-1 54, I $61,178,243,266$, 295, 322, 327 sq.

Saïd Boulifa, $6 n .^{4}$, I I $7 n^{2}, 258 n^{1}$

Saint, a father-in-law like a, 3 I I

Saints, the, of the district, $208,296$. See Shrines

Salmon, G., $6 n^{2}, n .^{3}$ and $n .^{5}$ sq., $20 n$. ,
$57 n ., 77 n .^{2}, 82 n .^{3}, 117 n .^{1}$ sq., $118 n .^{3}$, I $25 n$., $168 n$. $^{2}$

Salt, 43, 78, 89, 90, 103-105, 1 23, 147, 1 $50,162,166,181,187,251,256$, $25^{8}, 261,296,306,322,343$

"Salutation, the," I 39

Samter, E., 23 n., $26 n_{.^{1}}$ sq., 12 I $n .^{1}$, $122 n 0^{3}$ sqq., $163 n .^{2}$, I $87 n^{2}$, I $89 n^{4}$, $196 n ., 215 n^{1}$ sq., $216 n ., 219 n_{0}^{1}$, $220 n .^{1}, 221$ n., $222 n ., 257 n .^{2}, 264 n .^{1}$, $342,343,369$

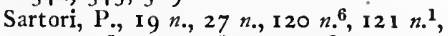
$122 n .^{5}$, I $23 n .^{2}$, I $50 n^{2}, 217 n$, $257 n .^{1}$ sq., $25^{8} n .^{3}, 268 n .^{2}$

Sautayra, $64 n .^{3}, 65 n .^{2}$

Schoolmaster, the, 29, 36, 305. See Index of Arabic Words, $f q t$

Schroeder, L. von, I9 $n_{.}, 26 n_{*}{ }^{1}, 86 n^{1}$, $87 n .^{1}$, I 2 I $n .1,163 n .^{2}$ and $n .4,164 n$., $215 n^{1}$ sq., 216 sq. n., $219 n^{1}, 220 n^{2}$, $258 n^{3}$

Schwally, F., $26 n^{2}$

Scribes, 21,128 , I 30, I 44, 176, 198 $200,253,280,305,338,349$

Second marriages, $328 \mathrm{sqq}$.

Seeds, throwing of, 2 I $6 n$.

Ș̌fru, 5, 92

Seligmann, C. G., 2 I $5 n^{1}$

Sellami, I $8 n^{2}$

Semites, 368

Separation between the sexes, I 8, I 9 , 313

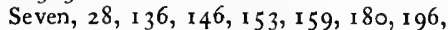
206-209, $215,229,235,239,248$, $249,256,273,277,281-284,286$, 290, 295-297, 299, 303, 305, 326, $350,351,35^{6}, 363$

Seventh (or sixth) day after the bride's arrival at her new home, ceremonies on the, 29 I sqg.

"Seventh [day] of the bride, the," 294

"_ day of the bridegroom and bride, the," 293

Sexual intercourse, conception of danger attaching to, 1, 26, 27, 271, 334 sqq.; ceremonies supposed to facilitate, $\delta$, $151,152,164,177,179,192,(232$, 264 sq.), 348 ; prohibited in holy places, $334 s q$.

- shame. See Bashfulness

uncleanness, taboos connected with, 334 sqq.

Shammar, $339 n$. $^{\text {I }}$

Shareefa of Wazan. See Emily

Shaving, of the bridegroom, 102, 106. 120, 127, 1 30-1 33, 321 ; the bridegroom prohibited from, 290, 324

Sheep, 31, 33, 40, 43, 45, 47, 67, 77, 
$78,82,84,101,108,109,146,147$, $157,158,180,204,221,259,282$, $284,302,304,307,308,336,337$, $340,355,361$

"Sheep and cattle, the threshold of," $201,221 s q$.

Shelha, 4, $22 n .^{2}, 86$

Shæm Hârush, 338

Shereefa, belting the bride, 293, 294, 359 ; curses of a, 339 ; the, of Wazan, see Emily

Shereefs, 21, 22, 24, 35, 37 n., 38, 42, $43,45,53,60,86,128,166,167$, $261,305,339,359$

Shiahs, 17, 64, 122

Shloh, 2-5, $22 n^{2}, 84$. See Aglu, Ait Támeldu, Amzmúz, Demnat, Glawi, Great Atlas, Iglíwa, Infḍuak, Sūs

Shoes, throwing of, at weddings, $257 \mathrm{sq}$. $n .^{2}, 343$. See Slippers

Shops, $340 \mathrm{sq}$.

Shrines, 23, 28, 29, 5 I, 73, 186, 190, $213,296,305,326,334,335,341$

Sîdi 'Abdrrăhman lhănbûbi, 341

Ali Musa, 341

Búnwar, 34I

(Sìii) Bůțeyib, $5^{8}$

Daud, 335

Fraj, 139

(SIdI) Haltl, I $5 n^{I}$ sq., $16 n_{0^{1}}$ and $n .^{5}$, I $8 .^{1}, 64 n .^{1}$ and $n .^{3}, 65,74,85$, $86 n .^{3}$

\section{Lủâfi, 34 I}

Mbârậk ben 'Ăbẩbi̊, 54 sq.

Sieves, 195, 195 sq. n., 199, 247, 349, 353

Silver things, $52,72,73,8_{3}, 8_{4}, 9 \mathrm{I}$, $100,103,106,107,112,124,150$, $154,164,218 n .^{2}, 250,286,347$. See Coin

Singing, 89-92, 94, 96-98, 100-103, 105, I 1 2, 1 26, I 28, I 29, I 37-1 39, I 41, $143,144,148,149,154,155,162$, $166,172,178,179,184,188,197$, $201,202,206-208,212,226,240$, $241,267,271,272,278,280,283$, $287,297,320,322,323,344$

Sixth. See Seventh

Skeat, W. W., $118 n_{*}^{1}$ and $n_{*}^{3}, 120 n_{*}^{4}$, $122 n .$, I $60 n .^{1}, 16 \mathrm{I} n .^{2}$

Skin-sack, 100, 102, 103, 106, 123, $152,176,182,208,237,269,282$

Slaves, 4I, 44, 83, 2 I 3 sq.

Slippers, 30, 69, 78, 82, 83, 102, 120 , $150,178,183,232,233,235,237$, $256-258,260,290,303-305,321,325$, 354,356 ; worn with their backs pulled up, 102, I09, I I I, I12, I14,
$123,124,147^{-150,156,159,163 . ~}$ 25 I, 253, 254, 266, 290, 323, 331 sq.; smacking with, $157,162,198$, $248,25^{2}, 256.258,330,35^{6}$; the bride robbed of her, 200,223 ; the bridegroom robbed of his, 233,234 , 269,286 ; kept on at night, 239, 290, 323,331 ; throwing of, 244, 251 , $256,323,356$

Smith, W. Robertson, $56 n_{0}^{1}, 59 n_{0}^{1}$, $65 n 0^{3}$

Smith, William, $264 n$. $^{3}$

Snouck Hurgronje. See Hurgronje

Son-in-law, avoids his parents-in-law, 310 sq9.; term applied to a, 312 . See Young Husband

Sorrow, expressions of, 344

Sparta, $26 n_{.} \mathbf{1}$

Spirits, evil, 26, 27, 89, 99, 103, I 19, $122,123,160,231,235,237,255$, $256,321,335,342,343,351,352$, $357,358,362$, see Devil; the, of the place or district, 208, 244, 296. See Index of Arabic Words, (d) jnīn

Spitting, 199

Stallion, the bride taken to the bridegroom's place on a, 168, 19 1, 349

Steel, $123,162 . \quad$ See Daggers, Needles, Swords

Sterility, supposed to be caused by evil spirits, $35^{2}$. See Fertility

Sticotti, P., I $87 n .^{2}$

Stones, saintly cairn pelted with, 129, 323 ; thrown over the bride, 169-171, $173,176,177,179,180,190,323$, $326,353,357$; at the bridegroom's people when they come to fetch her, 180, 186, 345 ; at bridal processions when they meet, 191

Straits of Gibraltar, the, 3

Sugar, 24, 29, 40, $43,47,78,104,181$, $199,261,284,301-304,308$

Suhrawardi. See 'Abdullah al-Ma'nun Suhrawardy

Sultan, the bridegroom regarded as a, $97,102,106,1_{1}, 118,274,361$

Sun, water which must not be exposed to the, 352

Sunnis, 17, 64. See Hanafts, Marlikis

"Supper, the," 301

Süs, 2, 3, 66, 92, 252, 328. See Aglu, Ait Táměldu

Swords, 97, 99, 102, 104, 1 06-109, I I 1, I 1 2, 1 23, 149, 1 55, 1 62, 235, 237 , $239,242,244,251,255,256,282$, $290,322,356$

Syria, I $18 n .^{3}$, I60 $n .^{1}$, I61 $n .^{2}$ sq., 162 
$n^{2}, 187$ sq. $n .^{3}, 188 n .^{3}, 217 n .^{1}, 222$ n. sq.; Nestorians of, $164 n$. See Aleppo

\section{Táfga, 67}

Tafilelt, 138

Tangier, 4, 6, $20 n_{\text {., }} 196 n$., 264, 329 $n_{\text {. }}$ sq., 337 ; nhär d-dbêha at, 78, I41 ; fetching of the bride at, $86,87,167$ sq.; ceremonies in the bridegroom's home previous to the wedding at, 117 sq. ; in the bride's home at, 140 sq9.; end of the wedding at, 293, 295; later ceremonies and taboos at, $300 \mathrm{sq}$.

Tangles, as impediments, 264

Tar, $37 n$.

Tent, the bride taken round the bridegroom's, 197, 198, 200, 206, 209, $215,326,331$; beating it with a cane, 200, 204, 218, 327, 331 ; flinging the cane at it, 200, 205 ; smearing butter on the horizontal pole supporting its roof, 201, 205, 207, 221 ; taken to the four corners of it, 201, 202,22 sq.; hurling a lamb over it, 204,22 I, 36 I

\section{$6 \mathrm{I}$}

-cloth, as an instrument of $l \dot{\bar{a}} r$,

- pole, embraced by a runaway wife, 60,63 ; smeared with butter by the bride, 201, 205, 207, 221; put into her lap, 202, 349

Tents, weddings celebrated in, pitched for the occasion, $200 \mathrm{n}$., 204, 206

Tetuan, 2

Thomson, Joseph, $26 n$. $^{\mathbf{x}}$

Three, 4I, 109, I 51 , I $57,179,185,186$, 190, 197, 200, 201, 203-206, 211 , $212,214,215,218,231,240,244$, 250-252, 254-256, 297, 306, 324-327, $330,332,35^{\circ}, 35^{6}$

Threshing-floor, $336,339,340,36$ I

Threshold, the, 218 sq. $n_{*}^{2}$; an egg buried underneath, 89 sq.; must not be stepped upon by the bride, 185 , 1 89, 219,220 sq. $n .^{2}, 324$; considered haunted by jnīn, 2 r 9 sq.; fear of, $220 n{ }^{1}, 369$; blood sprinkled on, 262

"Threshold of boys, the," 201, 221, 222, 349

"—_ of cheapness, the," 202, 22 I sq.

"— of safety and quietness, the," 201, $221 \mathrm{sq}$.

"— of sheep and cattle, the," 201, 221 sq.

"Time of the woman, the," 238 sq.

Tlemcen, $17 n .^{2}$, I $20 n .^{2}$ sq., $264 n .^{2}$, 3 I $n$.
Tlĩq, $57 n$. , $117 n .^{1}$, I $18 n 0^{3}$, I $68 n .^{2}$; mákla among the, 77

Todd, Mrs. M. L., $87 n .^{1}$, $160 n .^{1}$

Torches, 167

Torres, Diego de, $85 n .^{2}$

Touareg, $19 n$. See A haggar, Ahnet

Tours, made by the bridegroom and his friends, 108, I 09, I I I, I I 4, 28 I-286, 333 ; by the bride and her girl-friends, 145, $155 \mathrm{sq}$.

Train, Mr., $257 n .^{2}$

Transliteration of Arabic and Berber words, I I sqq.

"Transportation," the, I 33 sq.

Tremearne, A. J. N., I $18 n^{1}$, $123 n^{2}$, $160 n^{1}$

Tripoli, $87 n .^{1}$, 1 $60 n^{1}, 3^{67}$

Trousseau, the bride's, $34,83,84,185$. See Dowry

Trumbull, H. C., $84 n ., 87 n^{2}, 188 n .^{5}$, $219 n .1,222 n$.

Tsul, 3, 4, 263; fetching of the bride among the, 87, I7 1 sq.; cleaning and grinding of the wheat which is to be used for the wedding among the, $90 \mathrm{sq.;}$ the bridegroom's hennaceremonies among the, 90, 99 sqq.; ceremonies in the bride's home among the, $146 \mathrm{sq}$.; arrival and reception of the bride among the, 195 sq. ; meeting of bride and bridegroom and the morning after, among the, 235 sq.; continuation and end of the wedding among the, 281, 293; later ceremonies among the, 298,302

Tunis, I $8 n .^{2}, 161 n_{*}^{3}, 313 n .^{2}, 367 s q 9$.

Turcomans, $25 n$.

Turkey, $87 n .^{1}$, I 6 I $n_{.}^{3}, 220 n^{2}, 257 n_{*}^{2}$, $263 n 0^{3}$; Greeks of, $255 n_{0}{ }^{1}$

Turning the head, prohibition of, 172 , I $89,231,250,255,295,324,353$ sq.

Twins, $154,155,349$

"Tying of the hayẹ, the bride's beginning and," 142, 143, 260, 265, 349, 354

Tylor, Sir E. B., $316 n$.

Ujda, $2 s q$ :

Ulẩd Bu-Äzîz, 3, 4, 261, 336 sq. ; betrothal among the, 32 sq9.; marriages between cousins among the, 53; dowry among the, $66,67,82$; dhā̃ among the, $82,83,331$; time for weddings among the, 87 sq.; the bridegroom's henna-ceremony among the, 105, 199; ceremonies in the bride's home among the, I 57 s99.; meetings of bride and bridegroom and 
subsequent ceremonies among the, 158 , 159,238 sq.; fetching of the bride among the, 173 sq.; arrival and reception of the bride among the, 197 sqq.; continuation and end of the wedding among the, $282-284,290$, 291, 299; later ceremonies and taboos among the, 302, 311 sq.; second marriages among the, 329 sqq. See Ulầd Râfa

Ulẩd, Jâma', 294, 295, 298

- Râfa, 66

Unlucky numbers, $7 \mathrm{I}$

Untying of knots, 232, 264 sq.

Van-Lennep, H. J., 75 n., $120 n_{1}^{2}$, $160 n .{ }^{1}, 161 n^{3}, 162 n .^{3}, 164 n ., 186$ $n_{0}^{1}$ sq., $187 n_{0}{ }^{1}$ sq., $188 n_{0}{ }^{3}, 189 n^{3}$

Vassel, Ph., 22 n.1

Vegetable gardens, 336, 340, 353

Villot, E., $18 n_{0}^{2}, 161 n_{0}^{3}, 221 n_{0}^{2}$, $264 n$., $268 n$. ${ }^{1}$

Virginity, marks of the bride's, 159, $228,230,232,233,236,237,239-$ $243,245,246,248-254,266-268$, 362,368 . See Defloration of the Bride

"Vizier, the." See Best-man

Vowel sounds, rendering of Arabic and Berber, 12 sq.

\section{Wad Dră, 2}

Walnut root or bark, $83,105,120,153$, $158,161,176,182,193,194,202$, $213,214,216,231,233,242,250$, $266,282,283,295,306,322,327$ sq.

Washing. See Bathing and Washing

Water, from the sanctuaries of seven saints, 28 sq.; the grit removed from the wheat which is to be used for the wedding thrown into, 9c, 91, 93 sq.; used in various ceremonies, 97,121 , 122, 126, 1 28, 1 36, 144, 162, 185 , 190, 231, 232, 255, 297, 298, 321, 351 sq.; the sight of, avoided by the bride, 166,187 ; sprinkled on her, $177,180,190,203,209,215,216$, $326,347,348,357$; offered to strangers who come as guests, I9I ; sprinkled by the bride on the people, $198,216,348$; sprinkled on the cattle, 208 ; offered to the bride or young wife to drink, 212, 215, 297, $326,35^{\circ}$; drunk by bride and bridegroom, 232, $257 \mathrm{sq}$.; fetched by the young wife, 295-298, 350 ; sprinkled on her, 304. See Bathing and Washing

\section{Waves, seven, $35 \mathrm{I}$}

Wayte, William, $264 n^{3}$

Weather, ceremonies supposed to influence the, 7 sq. See Rain

Wea ving-stool, $15 \mathrm{x}, 152,356$

Wedding, Arabic and Berber names for, 85 sq.; time for the celebration of a, 86 sqq.; baraka ascribed to a, 143 ; the, celebrated in tents pitched for the occasion, 200 n., 204, 206; knots avoided at a, 264

"Wedding, the day of the," 140,274

" Arabic Words, där l'örs

"_-_, the night of the," 213

Wedding-feast, the, should be held in the bridegroom's home, 85 ; duty to accept an invitation to, 85

Weddings, several, celebrated on the same occasion, 203, 206, 212 sq.

Weeping. See Crying

Weinhold, K., $19 n$.

Wellhausen, J., $18 n .{ }^{2}, 19 n_{0}, 54 n_{\text {., }}$ $56 n_{r}^{1}$ and $n .^{3}, 59 n .^{1}, 65 n{ }^{3}$

Westermarck, E., 38 n., 61 $n_{\text {., }} 82 n^{2}{ }^{2}$, $87 n .^{3}, 118 n^{2}$, I $19 n_{0}, 120 n^{1}$ and $n .5$, $121 n^{2}, 122 n .^{1}$ sq., $123 n .^{2}, 138 n$, $145 n ., 163 n .{ }^{4}, 201$ n., $220 n^{1}, 254$ n., $25^{8} n^{3}, 259 n^{1}, 260 n^{4}, 267 n .^{2}$, $269 n$., 295 n., $321 n^{3}, 33^{6} n^{1}{ }^{1}$ sqq., $339 n{ }^{2}, 340 n^{1}{ }^{1}$ and $n .{ }^{3}$ sq. $343 n .^{5}$ sq., $344 n ., 351 n .{ }^{1}, 352 n .^{1}$ and $n .{ }^{3}, 360 n$. , $365 n \cdot 1,370,374$

Wetzstein, J. G., I $18 n^{3}$

Wheat, $33,45,47,67,77,79,82,322$; ground in the fiancée's home with a silver coin underneath the handmill, 33,152 sq.; cleaning and grinding of the, which is to be used for the wedding, $88-95,319,320,324,347$; ground by the bride over her uncovered right thigh, 153,162, 353 ; offered to the bride, $197,198,216,217,327,348$, 357 ; thrown by her over her head, $197,217,327,357$; on the people, $198,217,348,357$; ground by the young wife, 298

White objects used in ceremonies, 7,8 , $25,33,89,99,106,111,124,128$, 218 sq. n. ${ }^{2}, 253,261,347,357$. See Eggs, Milk, Silver Things

Widow, marriage with a deceased brother's, 59 sq.; allowed to dispose of her own hand, 59 ; in her father's power, 59 sq.; liable to be sold by her deceased husband's family, 60 ; dowry given for a, 66-99, $71-74$, 328 ; wedding ceremonies in case the 
bride is a, 154,329 s99.; remarriage of a, 328 sq9.

Wilken, G. A., $55 n .^{1}, 56 n .^{1}$

Wilson, C. T., $17 n .^{2}, 21 n ., 56 n ., 75$ n., 125 n., $188 n .^{2}, 215 n .^{2}, 218 n$., $219 n .1,222 n$., $268 n .^{2}, 291 n{ }^{1}$

Winternitz M., $19 n ., 162 n ., 163 n .4$, $215 n_{*}^{1}, 216 n ., 219 n^{1}, 220 n^{1}, 255$ n. ${ }^{1}$

"Wish of a good evening, the," 95

Witchcraft, $91-94,123,124,150,165$, $172,173,176,179,183,188,197$, $23 \mathrm{r}, 290,324,33^{8}, 342,3^{6 r}$

Witnesses at the conclusion of a marriage, $17,18,52$

"Woman's morning, the," 249

Women, kidnapping of, $6 \mathrm{r}, 80 \mathrm{sq.}$; fear of old, 176 ; opening their belts, 262 ; as guests, 262 sq.; notions regarding, $33^{8}$ sqq.; as asylums, 339 ; taboos to which they are subject, 339 sqg.

- the, related to the bride must take part in the ceremony called $t^{s} a$ iséq, 139.; who take part in a wedding paint themselves with henna, antimony, walnut root, ochre, saffron, or hárqoṣ, 153, 157, 161, 283, 327 sq. ; curse the fathers of the bride and bridegroom, 197, 223, 346; attack the bridegroom, 198, 199, 211,223 , 345 sq.; defend the bride against the young men's attempts to rob her, 204 , 223,346 ; have fights with the bachelors, $245,247,261,268,346$; belonging to the bridegroom's family have their hair open, 291,328 ; living in the village of the young wife's parents smear their hands with henna, 303. See Girl-friends of the Bride

Wool in magical practices, 218 sq. $n .^{2}$, $222 n ., 26 \mathrm{I}$

Wortabet, G. M., I6o $n^{1}$, $161 n^{2}$ sq., I $62 n .^{2}, 188 n$. and $n .^{3}$

Wrede, A. von, $164 n ., 186 n .^{1}, 188 n .^{2}$ and $n .^{5}$

Wuttke, A., $305 n$.

Yiblis. See Devil

Young couple, the, perform a sacrifice, 213 ; visited by the wife's mother, 291, 292, 303 sq.; visit the wife's parents, 300, 302, 304, 306 sq9. ; receive food from them, $301,308 \mathrm{sq}$.; kiss them on the head, $302,307,308$, 310 ; give them presents, 302,306 sqq.; ceremony supposed to make them friendly to each other, 305 ; paint the heels of their feet with the blood of a sheep or goat, $3 \circ 5$; give a feast, 305 ; abstain from sleeping together, 306 ; received with milk by the wife's mother, 308 ; give bread to the people whom they meet on the road, 309

husband, the, kisses the heads or hands of his parents, $48,3 \times 4$ sq.; gives to his wife a hâyệk, 143 ; a headkerchief or a ring, 286 ; pays a visit to his parents-in-law, 291, 300-302, 304,306 sqq.; gives them a present of food, 291, 301, 302, 306 sq9.; kisses one or both of them on the head, 291, 302-304, 307 sqq.; buys fish, 299, 347; gives a feast to his father- and brothers-in-law, 301; gives money to his mother-in-law, 304, 308 ; shy of her, 304, 311 sq.; of his parents-in-law, 304, 307, 309 sqq.; of his brothers-in-law, 310 sqq.; of his own parents, 314 sqg.; receives milk from his mother-in-law, 304 ; his wife putting new slippers on his feet, 305,354

- wife, the, receives a present from her husband, 143, 286; goes to fetch water, 295-298, 350 ; places herself under the protection of the spirits and saints of the district, 296 ; gives bread to the dog of the house, 296, 357; makes offerings to the saint whose shrine she visits, 296 ; certain water ceremonies to which she is subject or performed by her, 297, 298, 350; grinds wheat and prepares the supper, 298 ; fetches palmetto leaves and makes a rope, $298 ; 348$; together with her mother-in-law subject to a curious ceremony, 298 sq.; makes bread, 299; fish cast on her feet, 299, 353 ; must keep to the house, 300 ; visits her parents, $300-304,306-310$, 324,362 ; has a hot bath, 301,306 ; dressed up as a bride, 301 ; gives presents to her parents or one of them, $301,302,306-310,362$; receives presents from them, 301-303, 307 sq9.; baraka ascribed to, 302, 3०3, 308, 309, 362 ; receives hospitality from the people of her own village, 302 ; kisses her parents on the head, 302,303 , $307,308,310$; kisses the heads or hands of other relatives, 302 sq.; her feet washed with milk by her mother, 302 sq.; removes and kisses her 
parents' slippers, 303 ; smears henna on her hands, 303 ; sprinkles henna on the domestic animals, $3 \circ 3,362$; receives presents from relatives, 303 ; considered very susceptible to the evil eye, 303, 324; her mother painted with henna, 303 ; ceremonies to which she is subject on the fortieth day, 304-306, 325, 351; water sprinkled on her, 304 ; her slippers and girdle changed, 304 sq.; puts new slippers on her husband's feet, 305 , 354 ; charm suspended at her belt, 305; her hair plaited, 305 ; painted with henna, antimony, walnut root, and ochre by her mother, 306 ; still in a state of danger, 306 ; kisses her parents-in-law on the head, 317 ; kisses her father-in-law's head and hands, 317 ; has a bath in the sea, 35 I

Zachariae, Th., 14\& n., $220 n^{2}, 257$ sq. $n .^{2}$

Zémmur, runaway wives among the, 62 Zkara. See At Zihri

THE END 


\title{
BY THE SAME AUTHOR
}

\author{
Second Edition. Treo Vols. 8vo. I 4 s. net each.
}

\section{THE \\ ORIGIN AND DEVELOPMENT \\ OF THE MORAL IDEAS}

\author{
SOME PRESS OPINIONS
}

VOL. I.

ATHENAEUM.- " This book remains an achievement unsurpassed in its own kind, a perpetual monument of the courage, the versatility, and the amazing industry of its author."

R. R. MARETT in MIND._- “Dr. Westermarck's work fills me with profound admiration. . . . There is no book in any language that deals concretely with the evolution of morality on so grand a scale or in so authoritative a way.'

HAVELock Ellis in THE JOURNAL OF MENTAL SCIENCE."Throughout marked by an extraordinary degree of erudition which never becomes pedantic, by an invariably fair-minded and well-balanced attitude towards difficult problems, and by a power of broad and lucid presentation which recalls Buckle."

W. R. SORLey in THE BOOKMAN.-“ A standard work on a subject of first-rate importance. It is distinguished alike by breadth of view and mastery of detail, by skilful marshalling of evidence and by sound judgment."

\section{VOL. II.}

A. E. TAYLOR in NATURE. - "Dr. Westermarck's work is likely to remain for a long time a standard repertory of facts, which the moralists of every school will, no doubt, set themselves to interpret, each after his own fashion."

ATHENAEUM.- "By dint of a singular combination of virile qualities - pluck, resolution, and common sense-Dr. Westermarck has accomplished a inonumental work that places him in the first rank of living anthropologists."

R. R. MARETT in $M A N$. - "Dr. Westermarck is to be heartily congratulated on having brought to its full realisation a work designed on the most generous lines. The amount of erudition compressed into these two volumes is simply vast. . . . Of the book as a whole anthropologists can have but one opinion, namely, that in respect of reach and grasp alike it is masterly."

$$
\text { LONDON: MACMILLAN AND CO., LTD. }
$$




\title{
BY THE SAME AUTHOR
}

\author{
Third Edition. 8vo. I 4 s. net.
}

\section{THE HISTORY}

\section{OF HUMAN MARRIAGE}

\section{SOME PRESS OPINIONS}

SPECTATOR-"By far the most important contribution to our knowledge of a profoundly interesting chapter in human history that has yet appeared."

$A C A D E M Y$. - " Notable not only for its origin, but for its independence of thought. . . . At once takes an important place in the much-debated problem of primitive society."

SATURDA Y REVIEW.-" No brief notice can well give an idea of the field over which Mr. Westermarck ranges, and of his extensive learning in his subject."

WESTMINSTER REVIEW.- "All who are interested in the study of sociology will welcome the publication of Mr. Westermarck's really important studies. . . Mr. Westermarck has written a very able volume on the subject of human marriage, which, in our opinion, is calculated to set the world thinking again with a view to correcting preconceived ideas. The book is full of evidences of research which must have cost the author infinite pains. The book is not the result of a superficial effort, but of the earnest labour of the chief part of a lifetime."

MANCHESTER GUARDIAN.-"We noticed this remarkable book on its first publication, and need now only express our gratification at the appearance of a fresh issue of a book which all competent critics will allow to be one of great importance, whether its conclusions are finally accepted or rejected."

TIMES._- A very learned and valuable work. Mr. Westermarck propounds views which are at once novel and ingenious, and supports them with great variety of illustration and great cogency of reasoning. His book is scientifically conceived and scientifically executed, and it should command the serious attention of all scientific students of Anthropology."

LONDON: MACMILLAN AND CO., LTD. 

$H Q$

703

MI Wy

C. 2

University of California
SOUTHERN REGIONAL 405 Hilgard Avenue, LOs Angeles, CA FACILITY Return this material to the library
from which it was borrowed.

Bell, $D$

419192 
UC SOUTHERN REGIONAL LIBRARY FACILITY

A $000869085^{1}$ 
4

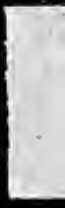

